\title{
Alternative factors driving pension fund investments
}

Citation for published version (APA):

Bonetti, M. (2021). Alternative factors driving pension fund investments. [Doctoral Thesis, Maastricht University]. Maastricht University. https://doi.org/10.26481/dis.20211126mb

Document status and date:

Published: 01/01/2021

DOI:

10.26481/dis.20211126mb

Document Version:

Publisher's PDF, also known as Version of record

\section{Please check the document version of this publication:}

- A submitted manuscript is the version of the article upon submission and before peer-review. There can be important differences between the submitted version and the official published version of record.

People interested in the research are advised to contact the author for the final version of the publication, or visit the DOI to the publisher's website.

- The final author version and the galley proof are versions of the publication after peer review.

- The final published version features the final layout of the paper including the volume, issue and page numbers.

Link to publication

\footnotetext{
General rights rights.

- You may freely distribute the URL identifying the publication in the public portal. please follow below link for the End User Agreement:

www.umlib.nl/taverne-license

Take down policy

If you believe that this document breaches copyright please contact us at:

repository@maastrichtuniversity.nl

providing details and we will investigate your claim.
}

Copyright and moral rights for the publications made accessible in the public portal are retained by the authors and/or other copyright owners and it is a condition of accessing publications that users recognise and abide by the legal requirements associated with these

- Users may download and print one copy of any publication from the public portal for the purpose of private study or research.

- You may not further distribute the material or use it for any profit-making activity or commercial gain

If the publication is distributed under the terms of Article $25 \mathrm{fa}$ of the Dutch Copyright Act, indicated by the "Taverne" license above, 
Alternative

Factors Driving

Pension Fund

Investments

Matteo Bonetti 



\title{
Alternative Factors Driving Pension Fund Investments
}

\author{
Matteo Bonetti
}


(C)2021 Matteo Bonetti

All rights reserved. No part of this publication may be reproduced, stored in a retrieval system, or transmitted, in any form, or by any means, electronic, mechanical, photocopying, record or otherwise, without the prior permission in witting from the author.

ISBN: 978-94-6423-503-6

This book was typeset using $\mathrm{ATE}_{\mathrm{E} X}$

Cover by Gabriella Bonetti: https://www.behance.net/gabriellabonetti

Printed by: ProefschriftMaken.nl 


\title{
Alternative Factors Driving Pension Fund Investments
}

\author{
Dissertation
}

to obtain the degree of Doctor at the Maastricht University, on the authority of the Rector Magnificus, Prof.dr. Rianne M. Letschert in accordance with the decision of the Board of Deans, to be defended in public on Friday 26 th of November 2021, at 14:00 hours

by

Matteo Bonetti 


\section{Promotors:}

Prof. dr. Rob Bauer

Prof. dr. Dirk Broeders

\section{Assessment committee:}

Prof. dr. Peter Schotman, Chair

Prof. dr. Marike Knoef (Leiden University)

Prof. dr. Theo Nijman (Tilburg University)

Prof. dr. Olaf Sleijpen

This dissertation was funded by De Nederlandsche Bank (DNB). 


\section{Acknowledgments}

The people that know me would see the following metaphor coming. A PhD truly is like a bike race. It would be too simplistic to compare it with a long climb. Becoming a researcher is more like racing Paris-Roubaix. On paper it is easy: a long flat road to success. Because, hey, the job is cool and you get a lot of exposure. However, the route is bouncing, full of pitfalls, and with sharp changes of direction. Methods are not always straightforward, the interpretation of results is often difficult, and your theories are constantly challenged. To succeed you need training and dedication. You read a lot, you start applying your knowledge to new ideas, and by trials and errors your further develop them. It is a pure learning process. Day by day, you gain momentum, the results start to come, and with a bit of luck you will reach your goals. You must put all your energies in steering the bike, but you are not alone. You have coaches that guide you through this process. Luckily, I found two outstanding coaches. Therefore, I want to first thank my supervisors, Rob Bauer and Dirk Broeders. Without them this thesis would not exist.

Rob, thanks for being such a great mentor. I would enter your office with a pretty solid idea in my mind, and I would get out with at least a couple questions to work on. By constantly challenging my theories you shaped and reshaped the way I think. You offered me a deep knowledge of the finance literature on the one hand, and the hands-on experience of a pension fund consultant on the other hand. I have always been impressed by your network that spans from the academics in top universities to the executives of the leading institutional investors. You made possible my visiting period at the Rotman School of Management, and you always created opportunities to promote my research. Dirk, I am deeply grateful for your guidance. You are one of the greatest experts in pension that I have ever met. Discussing my research with you has always been enlightening. When I would get stuck, you always managed to pointing me to right direction. With your position at De Nederlandsche Bank you made my $\mathrm{PhD}$ possible, and you have always supported me in the quest for data. You taught me the importance of precision and organization, all skills that I really 
lack of. Finally, you put an incredible effort in giving me instructions on how to write papers, an art that you certainly master. Thank you both for always believing in me.

I want to express my deepest gratitude to the committee for reading and assessing my dissertation. Thank you Peter Schotman, Marike Knoef, Theo Nijman, and Olaf Sleijpen. Your comments and questions will help to further develop my research. I am extremely grateful to Aleksandar Andonov for the ongoing cooperation that made me grow a lot as a researcher. I also want to thank Mike Simutin for hosting me during my visiting period in Toronto and for the willingness to discuss my research.

I was lucky enough to be selected to race for the team of the Finance Department at the School of Business and Economics of Maastricht University. Many thanks go to my colleagues here. I am profoundly thankful to Peter Schotman, Jaap Bos, and Paulo Rodrigues for their advice. Their offices are the "Bermuda triangle" of any empirical analysis performed in the department. If your methodology goes under their scrutiny, it will get out bashed but certainly strengthen. Peter, thank you for your willingness to discuss my doubts and to challenge my methods. Jaap, you have always inspired me to think outside the box. I try to be a creative researcher, and I owe part of this to your suggestions. I often came to you with questions, and I would go back to my office with a seemingly unrelated paper. After reading it, something has always clicked. Paulo, thanks for the passion that you put in helping young researchers. I learned so much from talking with you. After a few minutes of discussion, you would move to whiteboard and things would gradually start making sense. Teaching Options and Futures with you has been great. I probably learned more in your prep sessions than my students in class. Piet Eichholtz, the living example of how to combine success with a happy life style. Thanks for the numerous advice. A chat with you has always led to new ideas, good reads, nice bike rides, and obviously opportunities such as living in a luxurious house at the small price of feeding some sheep. This way, I can label myself as a field economist and a herding expert. Win win! Paul Smeets, thank you for the many research feedback and for good talks we had. I want to remember the ASSA 2017, where we spent a whole day walking around Chicago discussing ideas and future plans. Thomas Post, thank you for all the discussions 
about pension, for the nice chats, and for fun nights every Carnival. Roger Otten and Dennis Bams, thank you both for reading my papers and providing detailed remarks on the functioning of Dutch pension funds. Stefan Straetmans and Nils Kok thank you both for the inspiring discussions. I further want to thank Peiran Jiao, Jeroen Derwall, Rachel Pownall, Stefanie Kleimeier, Sanne Jongen, Sjoke Merk, and Carl Vandenboorn. Last but certainly not least, Francien Schijlen, Els van Aernsbergen, Carina Wijnands and Cecile Luijten. Thank you for your kindness, your help, and for making the life the of everybody in the department easy.

As in any bike race, strong team mates are necessary to succeed. I am extremely grateful to have had the opportunity to share my journey with an incredible group of fellow PhDs. First of all, I would like to thank my paranymphs Matthijs Korevaar and Martijn Stroom. Matthijs, a true friend and cycling buddy. Your curiosity and sharpness have always been inspiring for me. Next to discussing each other's projects, ideas and worries, we had great talks about economics and politics trying to address the big questions in the world. You know that you have a beautiful mind, so keep up the good work! On the road, we have an endless list of nice memories to share. Thanks for (still) being a great guide on the narrow Dutch streets. "Matteo, if I let you go, we will end up in Paris rather than going back to Maastricht". Martijn, in all these years, we shared plans, hopes, and frustrations. Research was not generally the topic of our talks, but, with your "yeah, but I'm a psychologist" approach you often had good remarks on my papers. Your positive attitude brought joy every (late) morning in the office, as soon as you would step in. Thank you for your friendship, the memorable nights out together, and for literally dragging me out of the building for coffee breaks. "Matteo you work too much". I am sure that your intelligence and your attitude would bring you far beyond what you might think.

Many more are the colleagues and friends that played a significant role during my time in Maastricht. Juan Palacios, my great office mate. Juan, in the long days and nights that we spent working side by side, you gave me support and motivation. I learned a lot from talking with you, but even more I appreciated your kindness. You have a bright future ahead of you, and I hope that our paths will cross again soon. 
Alessandro Pollastri, my big Italian brother in the department. Ale, since day one you guided me through the academic life with tips and tricks. You introduced me with the culinary scene of Maastricht. "Toscanella", the restaurant which you were the angel investor of, was the Place to go. There we would discuss music, fashion and football. But in the end, we would always end up complaining about the features of Italian politics and geography. Many years have passed, and I am really grateful to have you as a friend, and now as a colleague again. The gentle giant Mike Langen. Mike, I am always impressed by the number of ideas and experiences that you have to share. In almost any conversation that I had with you, I learned something new. Amazing! I wish you to succeed with all those ideas. Inka, the first person from the department that I met. As we both worked on similar topics, you were always an example for me. Thank you for the discussions, the happy memories and crazy parties that we had. Lidwien, I have always admired your determination and personality. Thanks for the great talks and for the many advice, e.g, "Matteo you should say NO". Thank you as well for the wisdom in replacing Tequila with water when I was no longer able to keep up with you guys. Nagihan, thank you for the long exchange of views that we had on our projects. We started the $\mathrm{PhD}$ at the same time, we went through the struggle of the job market together, and we gave each other support. My younger friends Colin and Marteen, thank you guys for the willingness to discuss my research, for the nice memories form travels, BBQs, and for still hanging out together from time to time. Irene, thanks for always being available to help me during the courses and with my papers. I wish you and Casper all the best for the future. Ming, thanks for the laughs and for the crazy stories about Chinese dorms. Luuk, you are one of the nicest persons that I have ever met. You were too patient when I was trying to practice my Dutch with you. Addy, thank you for your beautiful smile (I see, I see, I see) and for your wisdom. Nora, thank you so much for the advice you that you gave me on the last year of PhD. Ehsan, thanks for your friendship. A Huge thank also goes to my flat mate Nickolas Gagnon. Nick, your peaceful attitude has always relieved my chronic stress. Thanks for the nights spent talking about our projects and struggles. Thanks for the tasty dishes that you cooked for me and for standing my loud wheeze 
on the indoor trainer. Many more are the people with whom I shared paths during my PhD. Thank you Janek, Rasmus, Pomme, Annick, Joyce, Diogo, Kim, Michael, Runliang, Nico, Katrin, Tobias, Clarissa, Alex, Alexander, Bing, and Bram for the chats and memories.

A special thank goes to my family and to my Italian friends. Prima di tutto voglio ringraziare mia sorella Gabriella. Gabri, grazie per credere sempre in me. Grazie per aver colmato la mia assenza in questi anni, per il supporto quotidiano che dai a mamma e per aver spesso risolto molti problemi da sola. Anche per te è giunto il momento di spiccare il volo. Mamma, grazie per aver reso tutto questo possibile. Grazie per l'amore e per la pazienza che da sempre dimostri con me. Non sarei mai arrivato fino a qua senza di te. Un ringraziamento va anche al mio caro papà Felice, che indubbiamente sarebbe molto felice di essere qui oggi. Papà, grazie per gli insegnamenti e i valori che mi hai trasmesso.

Voglio poi ringraziare i miei grandissimi amici che, nonostante la distanza, mi regalano tanti momenti felici, mi supportano, e sopportano la mia "pazzia". Barro, grazie per la tua genuinità che fa sì che ogni volta che ci ritroviamo sembra che il tempo non sia mai passato (a parte per la tua panza). Bebo, grazie per chiedere costantemente qualcosa in più alla nostra amicizia, per lunghe riflessioni fatte insieme e per non lasciarmi mai andare. Benni, grazie per l'affetto e per la disponibilità che sempre dimostri. Berry, grazie per le discussioni e i buoni consigli che sai sempre dare. Ciollo, grazie per le belle memorie che abbiamo condiviso. Della, grazie per i molti dibattiti che abbiamo su sport ed economia, e per i nostri caffè quando ritorno. Dompi, grazie per la saggezza e per l'intelligenza dei tuoi discorsi, e soprattutto per ricordarci che il cuore da sempre i consigli migliori. Endo, grazie per l'amore e per essere sempre presente nel momento del bisogno. Non siamo più quelli di una volta, ma cresciamo per diventare migliori (ti mando sempre e comunque). Ghersi, grazie per avermi insegnato l'intraprendenza e la perseveranza. Johnny, grazie per la tua energia positiva, la tua curiosità e per l'affetto che non fai mai mancare. Lollo, grazie per farci divertire con la tua vivacità, le storie pazze e gli elogi alle forze dell'ordine. Pane, grazie per la tua simpatia e per assecondare i miei tanti scherzi col 
sorriso (Dfcpc). Ricky, grazie far coincidere le tue uscite con i momenti in cui sono a Savigliano. Steo, grazie per continuare a coltivare la nostra lunga amicizia. Ugo, grazie per le innumerevoli esperienze passate insieme, i lunghi scambi di vedute che più spesso vorrei poter fare e per il costante supporto che sento anche da lontano. Cuzzo e Kevin, grazie per l'affetto sincero e per mostrarmi che l'impegno porta sempre a buoni risultati.

Lastly, the most important person in my life. Alice, this dissertation is not dedicated to you because it already belongs to you. You have always believed in me, far more than what I do. You supported me when times were rough by patiently accepting the worst part of me. You gave me the strength and determination to carry on. Thank you for the things that you teach me, the plans that you make for us, and to put the two of us ahead of everything else. With your love and care you make a me better person every day. Thank you for never giving up on me. I love you. Thanks to Giovanna and Enrico for welcoming me in their family and for having gifted Alice to me.

Matteo

Delft, November 2021 
To my father 


\section{Contents}

1 Introduction 23

1.1 Complexity in pension fund management . . . . . . . . . . . . 25

1.1 .1 The Dutch case study . . . . . . . . . . . . . . . . . . . 27

1.2 Trustees and strategic asset allocation. . . . . . . . . . . . . . . . . 29

1.3 Advisors and strategic asset allocation $\ldots \ldots \ldots \ldots$. . . . . 31

1.4 Peers and security selection $\ldots \ldots \ldots \ldots \ldots \ldots$

2 The impact of trustees' age and representation on strategic asset allocations 35

2.1 The institutional setting . . . . . . . . . . . . . . . . . . 42

2.1 .1 The prudent person rule . . . . . . . . . . . . . . . . . . 42

2.1 .2 Pension fund governance $\ldots \ldots \ldots \ldots$

2.1 .3 Representation within the board of trustees . . . . . . . . 44

2.1 .4 Board characteristics and decision-making . . . . . . . . . 47

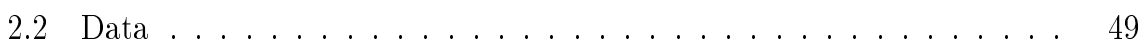

2.2 .1 Data description . . . . . . . . . . . . . . . . . 49

2.2 .2 Summary statistics $\ldots \ldots \ldots \ldots \ldots \ldots$

2.3 Hypotheses and model $\ldots \ldots \ldots \ldots \ldots$

2.3 .1 Hypotheses . . . . . . . . . . . . . . . . . . 54

2.3 .2 Model . . . . . . . . . . . . . . . . . . . . . 55

2.4 Board characteristics and strategic equity allocation . . . . . . . 57

2.4 .1 Baseline model . . . . . . . . . . . . . . . . . . . . . 57

2.4 .2 Relation between board age and strategic equity allocation . . 59 
2.4.3 Relation between gender and financial background and strategic

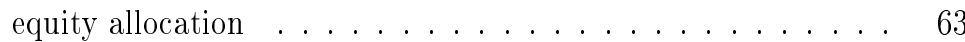

2.4 .4 Corporate versus non-corporate pension funds . . . . . . . . . 63

2.5 Stakeholder representation and strategic equity allocation . . . . . . 69

2.6 Board characteristics, alternative allocations, and returns . . . . . . . 71

2.6 .1 Board characteristics and alternative allocations . . . . . . . 71

2.6 .2 Board characteristics and equity performance . . . . . . . . 73

2.7 Conclusion $\ldots \ldots \ldots \ldots$

2. A Swap Ratio . . . . . . . . . . . . . . . . . . . . . . . . 77

2.B Average age of active participants and fraction of retirees . . . . . . . 80

2.C Role of the median voter in the board . . . . . . . . . . . . . . . . . . 82

2.D Internet Appendix . . . . . . . . . . . . . . . . . . . . . . 84

2.D.1 Summary statistics at the trustee level . . . . . . . . . . . . 84

2.D.2 Summary statistics corporate vs non-corporate pension funds. 84

2.D.3 Effect of board characteristics on the risky assets portfolio . . 87

2.D.4 Effect of board characteristics on the fixed income portfolio. . 88

3 Common advisor effect in strategic asset allocations 93

3.1 Data and networks . . . . . . . . . . . . . . . . . . . . . . . 98

3.1.1 Data $\ldots \ldots \ldots \ldots$

3.1.2 Pension funds' networks from multiple appointments . . . . . 102

3.1.3 Portfolio similarities and irregularities . . . . . . . . . . . . 106

3.2 Hypotheses $\ldots \ldots \ldots$. . . . . . . . . . . . . . . . . . . . . . . . . . 110

3.3 Methodology $\ldots \ldots \ldots \ldots$

3.3.1 Spatial autoregressive model and weighting matrix . . . . . . 111

3.3 .2 Common-advisor effect, a spatial panel approach . . . . . . . . 113

3.4 Results . . . . . . . . . . . . . . . . . . . . . . . . . . . . . . 114

3.4.1 Common-advisor effect on the SAAs . . . . . . . . . . . 115

3.4 .2 Disentangling the common-actuary effect . . . . . . . . . . . . 119

3.4 .3 Overlapping-trustees effect on the SAAs . . . . . . . . . . . . 121 
3.4 .4 Common pension fund characteristics and SAAs . . . . . . . . 125

3.4 .5 Discussion of the key findings . . . . . . . . . . . . . . . . 127

3.5 Robustness checks . . . . . . . . . . . . . . . . . . . . . 127

3.5.1 Time dynamics in the SAA decisions . . . . . . . . . . . . . . 128

3.5.2 Spurious regressions concerns . . . . . . . . . . . . . . . 132

3.6 Conclusion $\ldots \ldots \ldots \ldots$

3.A Spatial correlation coefficient interpretation . . . . . . . . . . . 136

4 Pension fund equity performance: Herding does not payoff $\quad 139$

4.1 Institutional Setting Data . . . . . . . . . . . . . . . . . . . . . 143

4.1 .1 The institutional setting . . . . . . . . . . . . . . . . . 143

4.1 .2 Security holding data . . . . . . . . . . . . . . . . . . . 145

4.2 Pension funds' herding . . . . . . . . . . . . . . . . . . . . . . . . . . . . 148

$4.2 .1 \quad$ Aggregate pension funds demand . . . . . . . . . . . . . . . . 148

$4.2 .2 \quad$ Aggregate herding measure . . . . . . . . . . . . . . . . . . . 150

4.3 Pension fund-level measure of herding . . . . . . . . . . . . . . . . . . 153

4.4 Herding and portfolio performance . . . . . . . . . . . . . . . 155

4.4 .1 Follower pension funds' portfolio performance . . . . . . . . . 155

4.4 .2 Herding over time $\ldots \ldots \ldots$. . . . . . . . . . . . . . 158

4.4 .3 Return prediction . . . . . . . . . . . . . . . . . . . . . . 161

4.5 Determinants of herding . . . . . . . . . . . . . . . . . . . . . . . 164

4.6 Alternative explanations for herding . . . . . . . . . . . . . . . . . . . 167

4.6 .1 Habit investing . . . . . . . . . . . . . . . . . . . . . . . 168

4.6 .2 Herding and style investing . . . . . . . . . . . . . . . . 170

4.7 Conclusion $\ldots \ldots \ldots \ldots$

4. A Appendix . . . . . . . . . . . . . . . . . . . . . . 174

4.A.1 Returns of followers in different markets . . . . . . . . . . . . 174

4. A.2 $\quad$ Predictive regression of pension funds' alpha . . . . . . . . . . 177

4.A.3 Determinants of herding including the number of securities in the portfolio . . . . . . . . . . . . . . . . . . . 177 
$4 . A .4$ Determinants of herding including piecewise-linear segments of

5 Summary of findings 181

$\begin{array}{lll}6 & \text { Research impact } & 185\end{array}$

6.1 Implications for pension funds . . . . . . . . . . . . . . . . . . . . . . 185

6.2 Implications for the pension regulator . . . . . . . . . . . . . . . . . . 186

6.3 Implications for financial stability . . . . . . . . . . . . . . . . . . . . 188

6.4 Implications for the pension reform . . . . . . . . . . . . . . . . . . . 189

6.5 Future research . . . . . . . . . . . . . . . . . . . . . . . . . . 190 


\section{List of Figures}

2-1 Age distribution of board members and beneficiaries . . . . 36

$2-2$ Board of trustees characteristics over time. . . . . . . . . . 45

$2-3$ Strategic Equity Allocation by Board Age . . . . . . . . . . 48

2-4 Pension fund asset allocation and funding ratio over time . . 53

$2-5$ Predicted equity allocation of corporate pension fund. . . . . 68

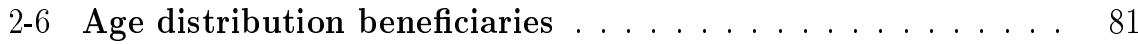

2-7 Average age active participants and fraction of retirees . . . . 82

2-8 Relation equity allocation and average participants age. . . . 92

3-1 Pension funds networks . . . . . . . . . . . . . . . . . . . . . . 105

3-2 $\quad$ Strategic asset allocation across quartiles $\ldots \ldots \ldots$. . . . . 107

$3-3$ Common-actuary effect on SAAs . . . . . . . . . . . . . 117

3-4 Common-actuary effect on alternative assets $\ldots \ldots \ldots \ldots$

$3-5$ Common type of actuary or common actuarial firm . . . . . 120

$3-6$ Overlapping-trustee effect on SAAs . . . . . . . . . . . . . 123

3-7 Overlapping-trustee effect on alternative assets . . . . . . . . . 124

3-8 Dynamic model for common actuaries and overlapping trustees 131

3-9 First-difference model for pension funds with common actuaries or overlapping trustees . . . . . . . . . . . . . . . . 134

4-1 Portfolio formation methodology . . . . . . . . . . . . . . . . 157

4-2 Followers and non-followers over time . . . . . . . . . . 160

$4-3 \quad$ Relation between herding and number of securities held over time . . . . . . . . . . . . . . . . . . . . . . . . 162 
4-4 Number of pension funds relying on active management . . . 166 


\section{List of Tables}

$2.1 \quad$ : Summary statistics $\ldots \ldots \ldots \ldots \ldots \ldots \ldots$

2.2 : The effect of board characteristics on the strategic equity

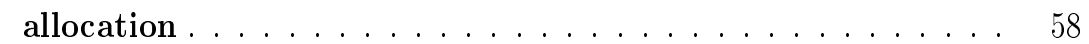

2.3 : The effect of young trustees on the strategic equity allocation 61

2.4 : Board characteristics and equity allocation in corporate pension funds . . . . . . . . . . . . . . . . . . . . . . 64

2.5 : Board characteristics and equity allocation in non-corporate pension funds $\ldots \ldots \ldots \ldots \ldots \ldots \ldots \ldots$

2.6 : Board characteristics and strategic alternative allocation . $\quad 72$

2.7 : Board characteristics and the performance of the equity

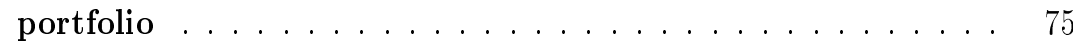

$2.8 \quad$ : Voting outcomes under the median voting theorem $\ldots . \quad 83$

2.9 : Summary statistics at trustees level $\ldots \ldots \ldots \ldots$

2.10 : Correlation matrix age board and participants age. . . . . 84

2.11 : Summary statistics corporate pension funds $\ldots \ldots \ldots$. . . 85

2.12 : Summary statistics non-corporate pension funds . . . . . 86

2.13 : The effect of board characteristics on the risky assets allo-

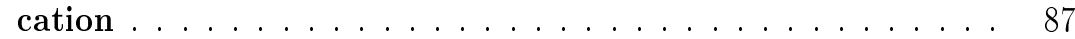

2.14 : Board characteristics and the strategic fixed income allocation 88

2.15 : The effect of young trustees on fixed income allocation. . . 89

2.16 : The effect of young trustees on the fixed income allocation in corporate pension funds . . . . . . . . . . . . . . 90 
2.17 : The effect of young trustees on the fixed income allocation in non-corporate pension funds . . . . . . . . . . . . . . 91

$3.1 \quad$ : Summary statistics $\ldots \ldots \ldots \ldots 101$

$3.2 \quad$ : Common asset managers, actuaries and trustees $\ldots \ldots \ldots$

$3.3 \quad$ : Strategic asset allocations across quartiles . . . . . . . . . 108

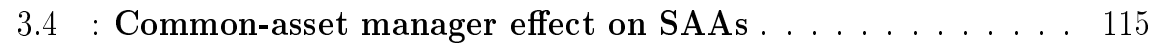

3.5 : Portfolio evolution of pension funds with similar character-

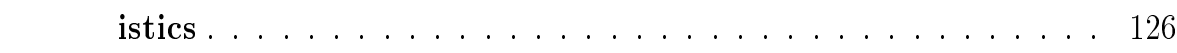

3.6 : Common-asset manager effect on the SAAs - Dynamic specification . . . . . . . . . . . . . . . . . . . . . . . . . . . 129

3.7 : Common-asset-manager effect on SAAs - First-difference analysis . . . . . . . . . . . . . . . . . . . . 133

$4.1 \quad$ : Summary statistics . . . . . . . . . . . . . . . . . . . . . . 147

4.2 : Number of securities traded by pension funds over time . . 149

$4.3 \quad$ : Aggregate herding measure . . . . . . . . . . . . . . . 152

4.4 : Follower pension funds and portfolio performance . . . . . 156

4.5 : Pension fund herding over time and portfolio performance 161

4.6 : Herding and pension fund future performance - Predictive

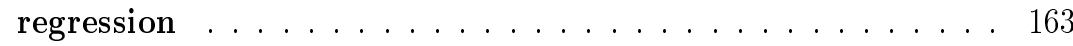

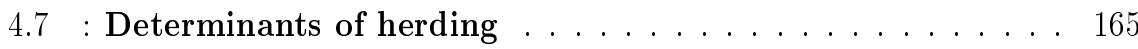

4.8 : Determinants of herding - the effect of active/passive man-

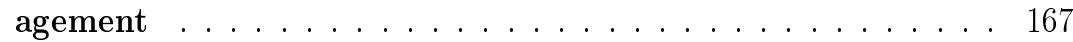

4.9 : Aggregate herding - buyer if increased return-adjusted portfolio weight $\ldots \ldots \ldots \ldots \ldots$. . . . . . . . . . . . 170

4.10 : Aggregate herding and style investing . . . . . . . . 172

4.11 : Follower pension funds and portfolio performance by secu-

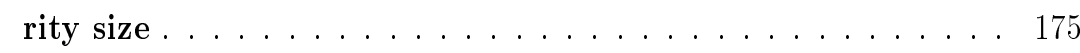

4.12 : Follower pension funds and portfolio performance by geographical area . . . . . . . . . . . . . . . . . . . . . 176 
4.13 : Predictive regression of pension funds' alpha $\ldots \ldots \ldots .177$

4.14 : Determinants of herding - number of securities held . . . . 178

4.15 : Determinants of herding with piecewise size segments . . 180 


\section{Chapter 1}

\section{Introduction}

The primary function of a pension is to smooth consumption over a lifetime by providing a post-retirement income. Pensions around the world are typically organized in a three-pillar structure (World Bank (1994)). The first pillar covers a public pension that the state administers. It is a basic pension that is available to all citizens and is usually financed by social insurance contributions and general tax revenues. The second pillar is an occupational fund that pension funds or insurance companies administer. It is a private, supplementary pension plan that is linked to an employment contract. It is often pre-funded by contributions from the employer and employees, often with some state support in the form of tax advantages on contributions and investment returns. The third pillar is a voluntary private pension that the insurance companies manage. Contributions are invested via an individual account and may benefit from tax incentives. Historically, countries have chosen diverse pension policies that have led to different levels of development for each one of these three pillars. For example, Italy and France primarily provide pensions via the first pillar. While the Netherlands and Denmark equally contribute to pensions of the first and the second pillars.

In the largest 88 economies around the world, the assets accumulated in the second pillar amounted USD 49.2 trillion at the end of 2019 (OECD (2020)). In this dissertation, I study these second pillar pensions, and specifically those that are administered by pension funds. The investments of these pensions serve to finance the 
current and future liabilities that they have towards their beneficiaries. Pension plans are usually classified into different types based on their characteristics (Bodie et al. (1988)). In the case of a defined benefit (DB) plan, the employee's years of service for the employer and wages determine the retirement benefits. Alternatively, in a defined contribution (DC) plan, the retirement benefits are a function of the investment returns from the invested contributions. Hybrid configurations of DB and DC plans are also possible.

In all pension plans, the decisions on the investment policy are key. A pension fund's board of trustees is responsible for making such decisions in the best interests of the beneficiaries. The mean-variance portfolio theory states that the optimal investment policy is driven by the expected risk and return characteristics of the different asset classes on the one hand and the pension fund's liabilities and risk aversion on the other hand (Sharpe and Tint (1990)). In the case of a DB plan, liabilities can in fact be seen as a short position in a series of bonds with different durations that are defined by the period in which benefits mature. In addition to this mean-variance approach, other factors might shape a pension fund's investment policy. Specifically, I empirically assess the effect that the following stakeholders have on the investment policy:

- Trustees

- Advisors

- Peers

The reasoning behind the expectation that these three stakeholders influence investment policy comes from the substantial complexity in the governance of pension funds. A board of trustees is the main decision-making body and is responsible for managing the pension fund. The members of the board are either elected or selected from the employers who sponsor the pension plan or the beneficiaries. These beneficiaries are the current retirees and workers plus, in some cases, the future beneficiaries 
that are not yet represented in the pension fund Trustees are not necessarily all investment professionals, and thus they contract external advisors such as actuaries and investment consultants to provide a series of advisory services such as asset and liability management, selecting strategic asset classes, and selecting the asset management firm. Furthermore, trustees delegate the execution of the investment policy to one or more asset management firms that adds another layer of complexity. The government is also a stakeholder because it is responsible for imposing regulation; defining the tax treatment of contributions, returns, and the benefit payments; and in some jurisdictions also acts as the guarantor of these benefits, for example, in the US public pension fund system. Finally, other pension funds (peers) are also stakeholders because they typically collaborate in a lobby organization to influence the decision-making of the government. Furthermore, pension funds compete in the same labor market for staff, contract the same advisors and asset management firms, and their investment returns and funding levels are exposed to the same public scrutiny.

I research the influence of trustees, advisors, and peers on two types of decisions on investment policy. To begin with, I analyze the effect of trustees and advisors on strategic asset allocations. These allocations capture the long-term policy weights across asset classes in a portfolio and to a large extend determine a pension fund's investment returns. Thereafter, I research the effect that peers have on security selection. Security selection entails the process of determining which financial securities are included in a specific portfolio. I treat both pension funds and asset management firms that invest on behalf of pension funds as peers in my study.

\subsection{Complexity in pension fund management}

The main goal of this dissertation is to investigate whether the complexity of governance hinders the efficient investment management of a pension fund. The presence of so many heterogeneous stakeholders generates conflicts of interests and misalign-

\footnotetext{
${ }^{1}$ Future beneficiaries are a stakeholder if they automatically enroll in a pension plan by accepting a job at the employer that sponsors the plan.
} 
ments of incentives that in particular play a role in the design of the investment policy. A conflict of interest arises when what is in a stakeholder's best interest is not in the best interest of other stakeholders. A misalignment of incentives occurs when stakeholders have an incentive to engage in behavior that enhance their own welfare, and other stakeholders have incentives to engage in different behaviors.

First, beneficiaries are heterogeneous in their investment preferences; this creates a potential conflict of interest. The prime example of heterogeneity is age. Assuming that human capital resembles a riskless asset, young beneficiaries with high human capital prefer to invest their retirement savings in risky asset classes, while old beneficiaries with low human capital prefer safe assets (Bodie et al. (1992) and Cocco et al. (2005)). Yet, trustees can only design a single investment policy for all beneficiaries (Merton (1983)).

Second, beneficiaries delegate the management of their retirement savings to a board of trustees that creates a possible conflict of interest. Trustees may value their private interests over the beneficiaries' interests when making investment decisions (Lakonishok et al. (1992a), Goyal and Wahal (2008)). For example, because of career concerns, trustees may favor active over passive portfolio management to increase short-term expected returns, even though this management will increase investment costs that might impair the long-term realized returns.

Third, trustees contract external advisors to assist in the design of the investment policy and delegate the implementation of that policy to asset management firms that can potentially create a misalignment of incentives (van Binsbergen et al.(2008)). The trustees have a fiduciary duty to act in the best interest of beneficiaries by pursuing the efficient and cost-effective management of a pension fund. Both the advisors and the asset management firms have different incentives and aim at maximizing their profits e.g., by using similar advice or investment strategies across multiple clients, and maximizing their contract length. Advisors and asset management firms are usually compensated on an annual basis; hence they are generally focused on the short term. But trustees, as a fiduciary duty, should have a long-term focus. Moreover, trustees, advisors, and asset managers may have different risk appetites. Trustees' 
lack of investment expertise combined with their trust in and familiarity with the advisors, and the advisors' persuasiveness, can accentuate information asymmetries between the two (Gennaioli et al. (2015)). For example, investment consultants or asset management firms have an incentive to recommend asset classes to their clients or to implement investment strategies that generate high fees, such as private assets. However, not all pension funds are able to independently set up the right checks and balances to assess the cost effectiveness of these asset classes (Andonov et al. (2015)).

Fourth, pension funds and asset management firms operate in an environment in which they influence each other's decision-making. Lack of knowledge or resources can encourage a pension fund to mimic the investment decisions of its peers. However, this herd behavior can lead pension funds to disregard private information and ultimately make suboptimal decisions that can affect their profitability (Banerjee (1992)). One example is the decision to invest in sophisticated asset classes for which the fund does not have enough inhouse knowledge(Andonov et al. (2018b)). Moreover, career concerns are high among investment professionals at asset management firms. For this reason, they have an incentive to follow what other asset management firms do to reduce their own responsibility in the event of poor performance Scharfstein and Stein (1990)). In fact, "Worldly wisdom teaches that it is better for reputation to fail conventionally than to succeed unconventionally [...]" (Keynes (1936)).

\subsubsection{The Dutch case study}

In this dissertation, I use Dutch occupational pension funds as a laboratory. It is an ideal environment to investigate the effect of governance complexity on pension funds' investment decisions for several reasons. First, the broad coverage of workers by this pension fund sector means that the pension income of nearly all Dutch employees and retirees is directly exposed to the investment management of a pension fund. A mix of mandatory industry-wide agreements and voluntary corporate agreements means that 91 percent of employees are covered by one or more occupational pension funds OECD (2017)). Generally, employees enroll in the pension plan offered by their employer by default. The vast majority of Dutch occupational pension funds are a 
hybrid configuration of DB and DC plans which is often referred to as a collective defined contribution (CDC) plan. Employees accrue nominal benefits based on their salary and an accrual rate, yet the real benefits depend on the investment returns. In particular, the annual level of indexation is determined by a function that takes the realized inflation (or wage growth) and the pension fund's funding ratio into account. In the case of prolonged underfunding, accrued benefits must be reduced to restore funding.

Second, the regulatory requirements in the Netherlands generate a homogeneous environment in which these pension funds operate. Corporate pension funds, industrywide pension funds, and professional pension funds all face the same regulations. The key regulatory requirements cover governance, investments and solvency. The key governance requirement is that each board of trustees should have an equal number of representatives of the employer and of the beneficiaries. Although pension funds can decide how many representatives of the beneficiaries' seats are taken by workers or retirees' representatives.2 In addition, pension funds can decide to include independent trustees on the board that do not represent a particular stakeholder group $!^{3}$ Pension funds face investment regulations, the main one being that the investment policy has to comply with the prudent person rule. This rule states the funds must be invested in such a way as to guarantee the security, quality, liquidity, and return of the portfolio as a whole. Further, the investment policy needs to be in line with the structure and the duration of pension liabilities. Lastly, pension funds are exposed to solvency requirements. A risk-based solvency test determines the required funding ratio such that the probability of the funding ratio dropping below 100 percent in a one-year horizon should be less than 2.5 percent. Risk is measured in this solvency test as the mismatch between assets and liabilities in which the present discounted value of the liabilities is determined by discounting nominal benefits against the cur-

\footnotetext{
${ }^{2}$ However, there is a limit to the number of trustees that represent retirees. This is 25 percent of the board's seats. If the number of participants is less than 10 percent of the sum of the number of participants and pensioners, then the pensioners' representatives can occupy more seats than employee representatives. See Article 102, sub 2, of the Dutch pension act.

${ }^{3}$ As of 2015 , a board could consist entirely of independent trustees. Article 101 of the Pension act rules the independent boards.
} 
rent term structure of the risk-free market interest rates. Furthermore, pension funds are required to have a funding ratio of at least 104.3 percent all the time.

Third, the broad coverage makes Dutch occupational pension funds one of the largest private pension sectors in the world, despite the relatively small size of the country's population. The mix of a well-functioning financial environment, substantial contribution levels, and supportive regulations make this sector a world leader in the adequacy and sustainability of a pension system. ${ }^{4}$ Therefore, the results of this dissertation can be used as a baseline for other jurisdictions that have a lower level of regulation and other types of governance complexity.

Fourth, Dutch pension funds report financial and governance-related information on a regular basis to their prudential supervisor, De Nederlandsche Bank. Accessing this information allows me to use bias-free data on the entire population of pension funds.

In the next sections I summarize the main chapters in this dissertation and my contribution to the literature.

\subsection{Trustees and strategic asset allocation}

In Chapter 2, I investigate how some characteristics of trustees influence their investment decisions and what the implications are for the beneficiaries. Following the prudent person rule, a board of trustees has the fiduciary duty to invest a pension fund's assets in the best interest of its beneficiaries. Therefore, trustees' own characteristics and interests should not affect their investment decisions. I provide evidence to the contrary. Trustees' characteristics affect the strategic asset allocation, in particular, of corporate pension funds. After controlling for pension fund characteristics, I find that boards with older trustees allocate less to equities. The high average board age lowers this strategic allocation by 7 percentage points. Moreover, a "gray" board in a "green" pension fund favors a low equity allocation even though the participants' characteristics predict a higher equity allocation (Campbell and Viceira (2002)). I

\footnotetext{
${ }^{4}$ Access 2019 MERCER global pension index here: https://info.mercer.com
} 
also find some evidence that boards with a greater share of female trustees allocate less to equity.

These results indicate that by considering their own characteristics, trustees might design strategic asset allocations that do not reflect the characteristics of all plan beneficiaries. Especially if the board does not reflect the population of beneficiaries. In fact, I show that the young and female population of beneficiaries are substantially underrepresented on the boards with respect to the senior and male population.

Board diversity has been a key topic of discussion within the pension sector in recent years. In January 2014 the Code of Dutch Pension Funds came into effect as a self-regulating instrument. The Code states that at least one man and one woman should hold a seat on the board of trustees. In addition, the board should have at least one member over the age of 40 and at least one member under the age of 40 . However, Dutch pension funds that implement the Code are falling short on improving diversity. For example, 82 percent of pension funds without people aged under 40 on their board failed to appoint a young trustee when filling vacancies: 5

Trustees' stakeholder representation also affects the strategic asset allocation. I find that corporate pension funds with a strong sponsor representation allocate more to equities. One additional board member who represents the sponsor leads to a 1.6 percentage points higher strategic allocation in equities. The sponsor of a corporate pension fund prefers a high equity allocation because it increases the value of the claim that it has on the pension fund's surplus assets in the event of overfunding. While, in the event of underfunding, the sponsor is not liable for the deficit (Treynor (1977)). Sponsor representatives are motivated to support the interests of their constituency to receive career benefits (Cocco and Volpin (2007)). This motivation fosters a principalagent problem between the sponsor trustees and the beneficiaries because a high equity allocation is not necessarily in the beneficiaries' best interest.

\footnotetext{
${ }^{5}$ See: https://www.ipe.com/dutch-pension-funds-falling-short-on-board-diversity/1 0029952.article
} 


\subsection{Advisors and strategic asset allocation}

In Chapter 3, I investigate the effect of external advisors on pension funds' investment decisions. The chapter builds on the empirical observation of a widespread similarity among the strategic asset allocations of Dutch pension funds, despite dissimilarities among their characteristics. This similarity, together with the fact that many Dutch pension funds contract the same actuaries and fiduciary asset management firms points towards the existence of a common-advisor effect.

The role of the fiduciary asset manager is key in the Dutch pension sector. This manager is appointed to provide a mix of advisory and delegated services for investment management on the entire portfolio of their clients. The asset manager provides advice on, for instance, the investment policy, diversification of risks, dynamic portfolio management, and performance measurement..$^{6}$ Although both actuaries and fiduciary asset managers have no direct decision power, which is held by the board of trustees, their professional relation and expertise can influence trustees' decisionmaking.

I contribute to the literature by showing a strong common-advisor effect. Pension funds make similar strategic investment decisions in the presence of a common asset manager or common actuary, despite significant differences in their liability structures, funding levels, or total assets under management. The effect is particularly strong in alternative asset classes, such as private equity, hedge funds, and real estate. If two pension funds increase their strategic allocation to alternatives by 10 percentage points in one year, a third pension fund that contracts the same asset manager increases its allocation to alternatives by 2.5 percentage points, all else being equal. Conversely, I find that pension funds with similar liability structures; that is, with beneficiaries of a similar age on average, do not make similar adjustments to their strategic asset allocations in the same year. Also pension funds with similar funding ratios do not make similar adjustments to their strategic asset allocations

\footnotetext{
${ }^{6}$ Therefore, fiduciary asset managers are more involved in strategic decisions and are different from delegated asset managers that are generally appointed to execute the strategic investment decisions taken by the board (van Binsbergen et al. (2008))).
} 
in the same year. These findings, combined with the common-advisor effect, indicate that asset managers and actuaries can transfer their investment beliefs to the pension funds they serve. These investment beliefs affect the investment policy on top of pension funds' characteristics. This transfer of investment beliefs can have a negative impact on pension funds' returns, if it leads them to select strategic asset allocations that are not in line with their liability structures, funding ratios, levels of sophistication, or organizational structures.

\subsection{Peers and security selection}

In Chapter 4, I examine the influence of peers on the security selection. The decision on selecting a security may be affected by the decisions made by other pension funds and asset managers, and this effect can result in correlated trades.

I study if pension funds, including asset management firms that work for pension funds, follow each other into and out of the same securities over time, that is, whether they herd. I find evidence of herding, as the current aggregate demand for securities is positively correlated with the past aggregate demand for the same securities. Next, I show that pension funds that herd underperform pension funds that do not herd by 1.32 percent on an annual basis. The results indicate that herding is related to scale, as small pension funds are more likely to herd 7 Herding is stronger in equity markets with lower analyst coverage such as small capitalization stocks and emerging markets in which learning from other investors can in principle be valuable. Yet, by herding it appears that pension funds acquire non-timely information at the expense of performance.

Pension funds' investment performance is disclosed publicly. Therefore, pension funds might be tempted to follow others' investment decisions because they are concerned about the judgement of their ability to make sound decisions (Avery and Chevalier (1999) ). I show that herding is related to these concerns, as pension funds

\footnotetext{
${ }^{7}$ I use the term pension funds for simplicity, even though herding originates from the asset management firm of each pension fund that is the actual decision-maker when it comes to security selection.
} 
herd consistently over time irrespective of their past performance.

The decisions to select securities directly affect the pension fund's performance. The investment performance of pension funds directly affects their funding level. In the Dutch context, the active participants in a poorly funded pension fund may face an increase in their contribution rate. Furthermore, both the active participants and the retirees may experience a reduction in indexation or even a reduction in accrued pension benefits following low returns. Therefore, plan beneficiaries bear the costs of herding.

In summary, this dissertation has three main empirical observations. First, the characteristics of trustees and their stakeholder representation influence strategic asset allocations. Second, advisors influence strategic asset allocations. Third, peers affect security selections. I discuss the implications of these observations for pension funds, pension regulators, and financial stability at the end of this dissertation in the research impact section. 


\section{Chapter 2}

\section{The impact of trustees' age and representation on strategic asset allocations*}

An occupational pension fund pools the retirement savings of a large group of participants (active workers) and retirees (former workers). Together the participants and retirees are the pension plan's beneficiaries 1 An occupational pension plan is often one of the most important financial products of an employee, and these plans come in two broad configurations: defined benefit and defined contribution. In a defined benefit (DB) plan, an employee's salary and years of service are the basis of the pension benefit level. In a defined contribution (DC) plan, contributions and investment returns determine the benefit levels. The DB pension plans, the focus of our study, typically offer beneficiaries limited scope for making individual investment choices. Instead, a board of trustees is responsible for making investment decisions in the best interest of beneficiaries. This responsibility is known as the "prudent person rule" and is found in many jurisdictions. This rule is of crucial importance because individual beneficiaries are largely constrained to self-insure against the unfavorable outcomes

\footnotetext{
${ }^{*}$ This chapter is co-authored with Rob Bauer (Maastricht University), Rien Bogman (KPMG) and Dirk Broederes (Maastricht University and De Nederlandsche Bank)

${ }^{1} \mathrm{~A}$ third group of beneficiaries are the so-called dormant participants. These former workers who have not retired yet are also known as "sleepers".
} 
of investment decisions made by the board of trustees.

In this study, we investigate whether the characteristics of trustees and the stakeholder group that they represent affect their investment decisions. First, we examine whether the age and gender of trustees influence the strategic asset allocations (SAAs) of the pension funds in which they are appointed. The justification for this analysis comes from the observation that boards on average deviate substantially from the beneficiaries that they represent. The average trustee is for instance much older than the average participant and much younger than the average retiree (see Figure 2-1).

Figure 2-1. Age distribution of board members and beneficiaries

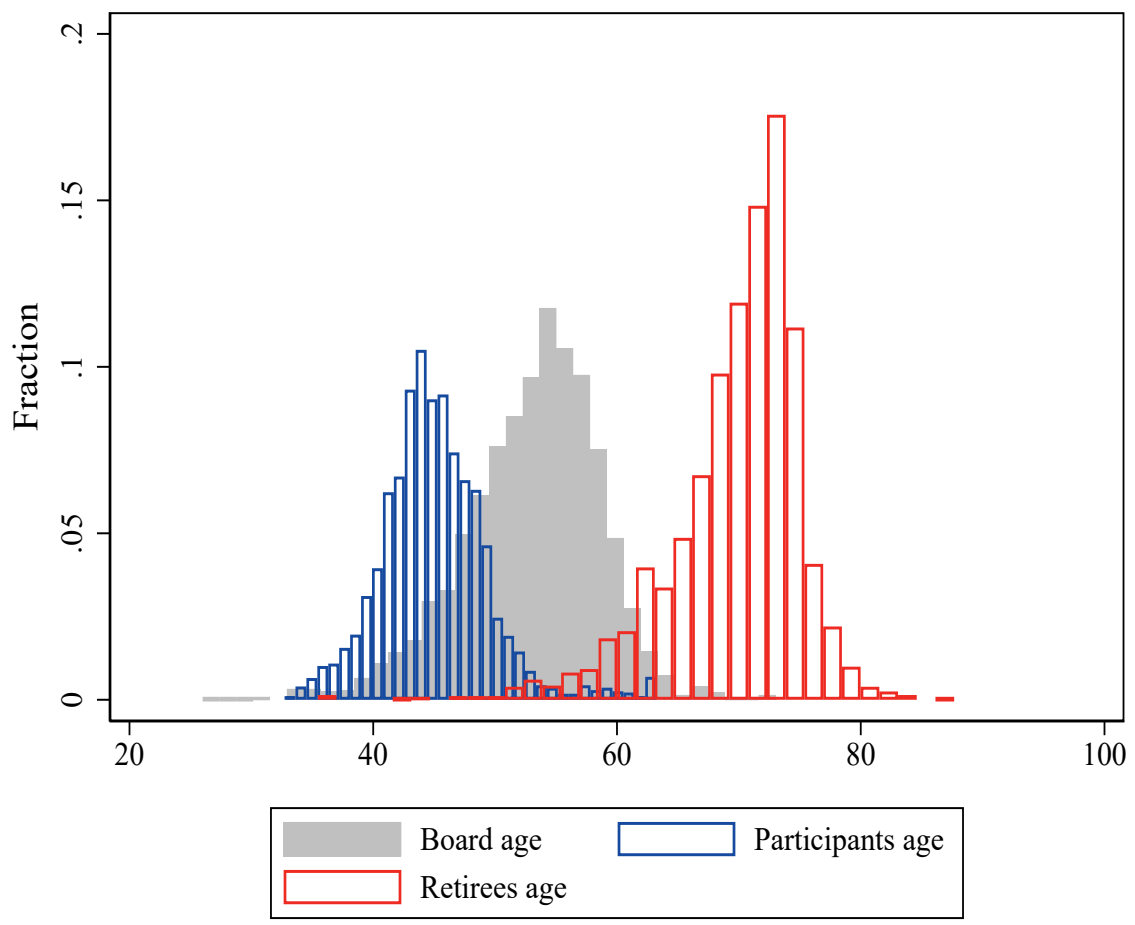

Notes: The figure shows the age distribution of the active participants in blue, of the retirees in red and of the board members in gray.

Furthermore, most trustees are male. These peculiar board characteristics might therefore affect their investment decisions $($ Falk et al. (2018) $)$. Second, we assess if the representation of stakeholders by trustees influences SAAs. Trustees might safeguard the interests of their constituencies to justify their appointments or to preserve their 
positions (Goyal and Wahal (2008); Lakonishok et al. (1992a)).

However, we hypothesize that there is neither a relation between trustees' characteristics and SAAs nor one between their representation of stakeholders and SAAs. We study these hypotheses for occupational pension plans in the Netherlands that are subject to the prudent person rule (Article 135 of the Dutch Pension Act). In our analysis, we rely on a unique database with detailed information on the investments and trustees of all DB pension funds in the Netherlands from 2007 through 2016. The database comprises proprietary, supervisory data from the De Nederlandsche Bank (DNB) and data from LinkedIn. There are different types of pension funds in the Netherlands: corporate pension funds and non-corporate pension funds. The latter group consists of industry-wide pension funds that cover all employees in the respective industry, and professional group pension funds that serve workers with a dedicated profession. In the Netherlands, the pension fund's stakeholders elect or select most trustees. However, there is a key difference between the types of pension funds that is relevant to our study. In corporate pension funds, employees typically elect or select their trustees from among themselves. Thus, these trustees are beneficiaries themselves. By contrast, in industry-wide pension funds, a labor union in that specific industry will typically select trustees to represent the employees. Thus, these trustees are not an employee of a corporation in the industry and therefore are not a beneficiary themselves. Further, independent trustees on a board are possible. Independent trustees do not represent a specific stakeholder group and are not beneficiaries themselves.

In contrast to what we hypothesize, our first main finding is that pension funds with more board members of a higher age invest less in equity after controlling for pension funds' characteristics. A one standard deviation higher average age of the board of trustees translates into a 1.5 percentage point lower strategic equity allocation. We then identify pension funds with a large age-representation gap as those with more than a 10-year difference between the average age of the board members and the average age of the active participants. These pension funds display, on average, a 2.5 percentage point lower equity allocation compared to pension funds with 
a low age-representation gap. Therefore, a "gray board" favors a low equity allocation despite the fact that the presence of "green participants" predicts a high equity allocation (Campbell and Viceira (2002)). However, we also find that young trustees provide a countervailing power to a gray board. Pension funds with a gray board and one trustee below the age of 40 years old on average allocate 2.1 percentage points more to equity compared to pension funds that have no young trustees on their gray board.

A possible explanation for these findings is that trustees base their decisions on their own optimal life-cycle investment strategies. From an individual perspective, old trustees have low human capital and prefer a lower equity allocation than young trustees who are endowed with high human capital (Bodie et al. (1992)) and Cocco

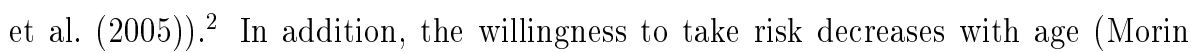
and Suarez (1983); Calvet et al. (2007); Malmendier and Nagel (2011); Dohmen et al. (2017)). These arguments become even more prominent if a trustee is also a plan beneficiary. In line with this potential explanation, we find that the trustee-age effect exists in corporate pension funds whose trustees are typically also beneficiaries. The effect is economically significant. For the participants in a corporate pension fund, the high average age of the board lowers the equity allocation by 7 percentage points. By contrast, we find no age effect in non-corporate pension funds whose trustees come from a labor union and therefore are not beneficiaries themselves. These trustees have no incentive to pursue their own optimal life-cycle investment strategies. Moreover, as trustees of industry-wide funds are generally labor union trustees, their decisions might be coordinated at the union level and therefore be less dependent on the features of the specific pension fund in which they are a trustee. Furthermore, non-corporate pension funds have more independent trustees. In fact, 6.55 percent of the trustees in non-corporate pension funds are independent. For corporate pension funds this percentage is only 1.83 percent. Finally, non-corporate pension funds on average also have larger boards so that individual board members have less influence on the

\footnotetext{
${ }^{2}$ Crucial to the optimal asset allocation over the life cycle is the correlation between equity returns and human capital returns, see also Benzoni et al. (2007). Age is typically considered a proxy for human capital with low risk, as in our analysis.
} 
investment policy. A non-corporate pension fund has on average 8.14 board members, while a corporate pension fund has 6.74 board members.

We also find, albeit less strong, evidence of a trustee-gender effect. Boards with a greater share of female trustees allocate less to equity. Pension funds that have one female trustee allocate 0.8 percentage points less to equity than similar pension funds with no female trustees on their boards. The trustee-gender effect on the equity allocation is statistically weaker than the trustee-age effect. However, we must take into consideration that females are substantially under-represented in boards. In 2016, on average boards had less than one female member, and 40 percent of pension funds even had no female trustees at all. Therefore, the evidence of a gender effect indicates that female trustees are not a silent minority. Our finding is in line with the empirical evidence that shows females are more risk averse than males (Vieider et al. (2015); Falk et al. (2018)).

Our second main finding is that corporate pension funds with a stronger employer (i.e. the plan's sponsor) representation on the board allocate more to equity than corporate pension funds with a balanced representation of stakeholders. One additional board member that represents the employer leads to 1.6 percentage points higher strategic equity allocation. An explanation for this is that employers have a claim on the pension funds' assets in case of overfunding (Treynor (1977)). Conversely, in the event of underfunding, the employers are not liable for the funding shortfall. At least not in the jurisdiction that we analyze. In fact, in a situation of severe underfunding pension funds are required by law to reduce the accrued pension benefits to restore full funding. Because of this asymmetry, employer trustees have an incentive to safeguard the interests of their constituencies by selecting a riskier asset allocation that increases the value of the employers' claim on surplus assets. Increasing the value of this claim can, in turn, translate into career benefits for trustees (Cocco and Volpin (2007)). If employer trustees consider their own career in the SAA, then this consideration fosters a principal-agent problem between themselves and the beneficiaries. Principal-agent problems in pension funds arise if the interests of the decision-makers are not aligned with the interests of the beneficiaries (Lakonishok et al. (1992a)). 
In many jurisdictions, principal-agent problems are mitigated through regulations on pension fund governance. These regulations typically clarify the rights and the responsibilities of the different stakeholders involved. These rules often contain requirements for internal supervision, for example, the agents (trustees) are controlled by a supervisory board that is itself accountable to the principals (beneficiaries) (Boeri et al. 2006) $3^{3}$ The aim of such rules is to promote that investment decisions are made in the best interests of plan beneficiaries. In the Netherlands, one of these rules establishes that each board of trustees should have an equal number of beneficiaries' trustees and employer trustees. This equality still generates dispersion in stakeholder representation because the objectives of participants and retirees are not necessarily aligned. As a consequence, the employer trustees are often in a dominant position compared to the fragmented representation of beneficiaries. To create a balance of power, independent trustees can be added to a board. These are external experts that are competent and that compete in a job market for trustees (Besley and Prat (2003)). Furthermore, the balance of power can be enhanced through an even age and gender representation. This balance helps to counterbalance the diverging preferences and interests among groups of beneficiaries and trustees and in turn strengthens the governance of pension funds. Our results indicate that Dutch pension funds have room to improve both age and gender diversity on their boards. Moreover, few pension funds have at least one independent trustee on their boards, although the average share of independent trustees grew from 1.6 in 2007 to 9.0 percent in 2016.

We contribute to the literature by showing that key trustee characteristics, such as age and gender, and stakeholder representation influence the investment decisions that the trustees make on behalf of pension plan beneficiaries. Moreover, our unique data facilitates us to examine the relation between the trustees' characteristics and

\footnotetext{
${ }^{3}$ In the US, corporate pension funds are regulated by the Employee Retirement Income and Security Act (ERISA) that was introduced in 1974. The US public-sector pension plans are largely regulated by state and local laws. See Brown (2008) and Brown and Wilcox (2009) for a detailed description of US pension plan regulation. In the European Union (EU), the directive on the activities and supervision of institutions for occupational retirement provision (IORP) was passed in 2003 and subsequently implemented by all member states. In 2016, the EU passed the IORP II directive to reaffirm common standards that ensures the soundness of occupational pension plans and better protects beneficiaries. See full text https://www .pensionseurope.eu/iorp-ii-directive
} 
their strategic investment decisions across pension funds with different governance structures. Despite the extensive corporate finance literature on board diversity and corporate decision-making (Adams and Ferreira (2009); Adams et al. (2010); Ahern and Dittmar (2012); Matsa and Miller (2013)), and despite the importance of institutional investors governance (Andonov et al. (2017); Rauh (2009)), a limitation on data has prevented extensive research on the relation between board characteristics and pension fund investments. $4^{4}$ The few exceptions are Pennacchi and Rastad (2011) and Bradley et al. (2016) who show how US public pension funds with a higher fraction of politically affiliated trustees report higher allocations to risky assets, or Cocco and Volpin (2007) who show that UK pension funds with a higher proportion of employer trustees have a higher equity allocation.

We also contribute to the literature on pension funds governance and performance (Andonov et al. (2018a); Ammann and Ehmann (2017); Phan and Hegde (2013)) by studying the relation between the dynamics in trustees' appointments and investment performance. We hypothesize that if young trustees favor riskier SAAs they can also do so by increasing the investments in active equity mandates with the aim of earning a higher benchmark-adjusted return. However, we show that pension funds that hire young trustees do not experience higher benchmark-adjusted equity returns. But we do find that the share of financially knowledgeable trustees is positively correlated with the benchmark-adjusted equity returns of pension funds. Logically, trustees' turnover can improve performance, if it is associated with an increase in investment expertise that is not necessarily captured by the age of a newly hired trustee Clark (2004)). Finally, we show that pension funds with larger boards allocate more to alternative asset classes, such as private equity, real estate, hedge funds, and commodities. This result is independent from the expertise of trustees, as the strategic allocation to alternatives is not affected by the share of trustees with a financial background.

The remainder of the study proceeds as follows: In Section 2.1. we describe the

\footnotetext{
${ }^{4}$ Verma and Weststar (2011); Swinkels and Ziesemer (2012) and Shi et al. (2017) study the diversity of pension fund boards that relies on survey data without assessing any interaction between diversity and the SAAs given the difficulties in finding a reliable data source on pension funds' investment portfolios.
} 
institutional setting in which we carry out our study. Section 2.2 introduces our data. In Section 2.3. we summarize our hypotheses and our empirical strategy. Section 2.4 presents the results of our analysis on board characteristics. Section 2.5 presents the results of our analysis on stakeholder representation. In Section 2.6, we analyze the effect of board characteristics on the strategic allocation to alternative asset classes and also the effect on equity returns. Section 2.7 concludes.

\subsection{The institutional setting}

Our study takes place in the well-established Dutch occupational pension system. In this section, we describe the prudent person rule, the governance of Dutch pension funds, and how different stakeholders are represented within the board of trustees. Then, we discuss how the trustees' characteristics can influence the decision-making by pension funds.

\subsubsection{The prudent person rule}

Article 135 of the Dutch Pension Act rules that a pension fund should invest its assets in the best interests of all beneficiaries. The prudent person rule is an open norm and does not contain quantitative investment restrictions. Nonetheless the Pension Act does specify the prudent person rule in a qualitative way. Showing that the trustees in principle should have little room to adjust the SAA towards their own preferences. The retirement savings must be invested in such a way as to guarantee the security, quality, liquidity, and return of the portfolio as a whole. Further, the investment policy needs to be in line with the structure and the duration of the pension benefits. The board of trustees also needs to verify the risk aversion level of its plan beneficiaries. The prudent person rule requires a pension fund to diversify its investments and invest the larger part of the assets in regulated markets. Furthermore, the board of trustees needs to disclose its stance with respect to sustainable investing.

The Pension Act also contains requirements with respect to the implementation of the investment policy. Specifically, for determining and implementing the invest- 
ment policy, a pension fund establishes a clear organizational structure in which risk management is adequately and independently structured to support careful and transparent decision-making. In addition, there must be a balance between the nature and complexity of the investment portfolio on the one hand and the available knowledge, experience and level of risk management on the other.

\subsubsection{Pension fund governance}

Pension funds in the Netherlands are organized as stand-alone, non-profit organizations whose goal is to execute the pension contract that representatives of employers and workers have negotiated. The pension funds are legally set up as independent trusts. A board of trustees is responsible for managing the pension fund's assets and administrating the beneficiaries' benefits. A supervisory board, a visitation committee, or non-executive trustees exercise internal supervision. The legislator delegates external supervision to two independent supervisory agencies: De Nederlandsche Bank (DNB) that exercises prudential supervision, and the Authority for the Financial markets (AFM) that is responsible for supervising the fund's market conduct.

When it makes decisions concerning matters of everyday policy, the Pension Act requires the board of trustees to balance the interests of all stakeholders (Article 105 of the Dutch Pension Act). However, when it makes decisions concerning the investment policy, the act requires the board of trustees to invest the pension fund's assets in the best interests of the beneficiaries: both the participants and the retirees (Article 135 of the Dutch Pension Act) $!^{5}$ Especially the participants need to feel that the pension fund represents their interests, as the Dutch pension system does not allow them to exit (see Hirschman (1970)). Employees have in fact no freedom to choose their own pension fund. They automatically enroll in the plan that is offered

\footnotetext{
${ }^{5}$ The act defines active participants as persons who contribute to the pension plan and who have not yet retired, and passive participants (sleepers) as persons who do not contribute to the pension plan and who have not yet retired. These are people who have changed employers and have not transferred their accrued pension benefits from one pension plan to another (Article 1 of the Dutch Pension Act).
} 
by their employer. The barriers to exit from the pension fund are high. An employee would have to resign, start working for a different employer, and then transfer any accrued pension benefits. This is known as "voting by feet", and it is a common feature in private and public pension funds in several other countries such as the US, the UK, and Canada (Dyck and Pomorski (2011)). Differently, in countries where participants have freedom of choice, the market acts as an external means of control, because participants can decide to opt out of a pension plan if they are not satisfied with the conditions provided (Kowalewski $(2012))$. Retirees cannot exit from the pension fund whatsoever. Pensions are an important part of compensation and therefore important to employers for labor market competition. For these reasons, and in contrast to many other financial sectors, all stakeholders (participants, retirees, and employers ) are represented on the board of trustees.

\subsubsection{Representation within the board of trustees}

Article 100 of the Dutch Pension Act establishes that each board of trustees should have an equal number of trustees for the beneficiaries and for the employer(s). Each pension fund's statutory requirements may also foresee some independent trustees. Furthermore, each pension fund can decide how many of the trustees it allocates to the participants and to the retirees. However, retirees cannot be represented by more than 25 percent of the trustees on the board $4^{6}$ This rule for retirees' representation may cause imbalances in the stakeholders' representations across pension funds. The more trustees are split between the participants and the retirees, the higher the effective power of the trustees who represent the employer(s). This is caused by the fact that the interests of participants and those of the retirees do not necessarily align. Participants may want to invest more in risky assets, while retirees may prefer to invest in safe assets. Participants are interested in low contributions, and retirees may push for higher contributions.

The law does not contain requirements on age or gender representation. In fact,

\footnotetext{
${ }^{6}$ If the participants are less than 10 percent of the total number of beneficiaries, then retirees can be represented by up to 50 percent of the trustees on the board.
} 
Figure 2-2. Board of trustees characteristics over time

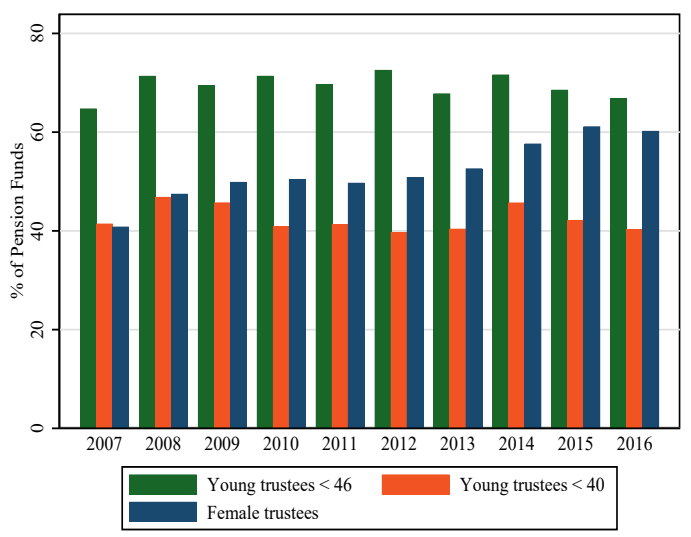

A. Board of trustees composition

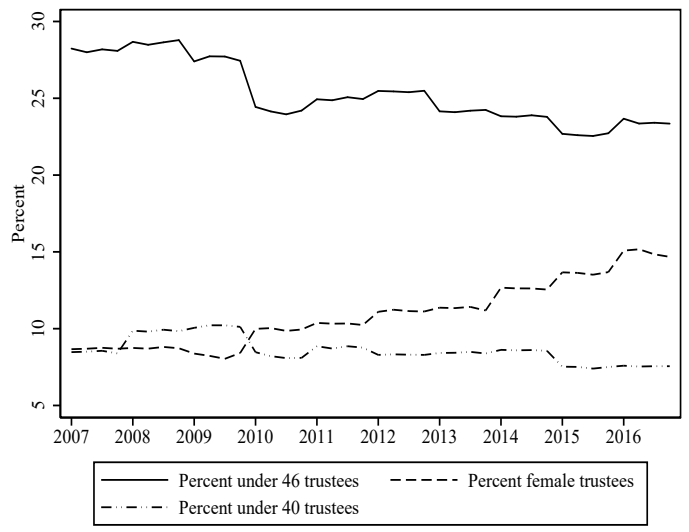

B. Percent of young female trustees over time

Notes: Panel A displays for each year the percentage of pension funds that report at least one young or one woman trustee in their boards. A trustee is classified as young if he or she is younger than 40 years old(in line with the Code of Dutch Pension Funds) or younger than 46 years old. The latter is the 25th percentile in the age distribution of trustees. Panel B shows the evolution of the average share of young and female trustees across pension funds.

senior males mostly occupy board seats. Young and female trustees are much less common. Panel A of Figure 2-2 shows that in 2007, only 40 percent of the pension funds had at least one trustee younger than 40 years old on their board, and 40 percent of the pension funds had at least one woman on their board. Therefore, the fact that board diversity has been an object of discussion within the pension sector 
for many years is not surprising. As a result of that discussion, in January 2014 the Code of Dutch Pension Funds came into effect as an instrument of self-regulation.7 The code contains a guideline that the board is to have at least one member under and at least one member over the age of 40 years old. Furthermore, the code states that at least one woman and one man should hold a seat in the board of trustees. Pension funds follow the code under the comply-or-explain principle. This principle means that pension funds comply with the code's standards or, alternatively, they must explain and justify in their annual report why they deviated from this standard. The non-mandatory nature of the code indicates that many pension funds find it difficult to comply with it. In 2016, only 40 percent of the pension funds had at least one trustee younger than 40 years old on their board (Panel A of Figure 2-2). But the percentage of pension funds with at least one woman on the board increased to 60 percent. However, this percentage means that 40 percent of the pension funds still had no female trustee.

Another way to express the characteristics of the boards of trustees is in Panel $\mathrm{B}$ of Figure 2-2, The panel shows the time series of the average share of young trustees and the average share of female trustees across pension funds. The average share of trustees under the age of 40 has decreased over time. This is also the case for the average share of trustees under the age of $464^{8}$ The introduction in 2014 of the Pension Fund Governance Act may be an explanation for this decreasing trend because, among other things, it requires a higher expertise to be hired as a trustee. Expertise is related to experience through age and therefore hiring of young trustees might have lagged. The act has the objective of strengthening governance by requiring higher expertise of trustees and stronger internal supervision ${ }^{9}$

\footnotetext{
${ }^{7}$ See the English version of the Code of Dutch Pension Funds: https://www .pensioenfederati e.nl/stream/codeof thedutchpensionfundsenglish2017.pdf

${ }^{8}$ We use 46 years of age because it corresponds to the 25 th percentile of the age distribution of all individual trustees in the sample. Thus, in this statistic we look at the share of trustees that are in the youngest quartile of the age distribution. We provide more details in Section 2.2 .2

${ }^{9}$ Moreover, the act offers three governance models. The first is the standard joint model that requires equal representation of employer and beneficiaries, with a maximum of two independent trustees. This model was the only possible governance structure of pension funds until the 2014 reform. In that year, the act introduced the independent model. In this model, the entire board consists of independent professionals. In 2014, the act also introduced the mixed model. The mixed
} 
Panel B of Figure 2-2 shows an increasing trend in female trustees. Yet, in 2016 on average only 15 percent of the trustees on a board were women, which means that the pension fund sector is still far from equal representation. Women count for 46 percent of the labor force in the Netherlands 10 Given that occupational pension funds cover nearly the entire population of Dutch employees, a fair representation of women on pension funds' boards means that the share of female trustees should be much higher.

\subsubsection{Board characteristics and decision-making}

We observe that boards on average deviate substantially from the beneficiaries that they represent. The average trustee is much older than the average participant and much younger than the average retiree (see Figure 2-1). Furthermore, most trustees are male. Despite these striking board compositions, the trustees' characteristics should not influence a board's investment decisions. Yet, the fact that older males dominate boards can influence their dynamics and the discussions that lead to the final decisions. For example, a subgroup of trustees can form an alliance to ensure that a particular board's decisions are in line with the subgroup's opinions. Similarly, highly respected and experienced trustees may put soft pressure on the other board members by expressing their personal opinions on the investment strategy. Although we cannot observe the decision-making of the board, we can observe some characteristics of trustees that can be more (or less) dominant on a board. These predominant characteristics might influence the board's decision-making (Falk et al. (2018)).

To illustrate this influence, in Figure 2-3 we plot the average strategic equity allocation of two groups of pension funds: pension funds with at least one young trustee on their board and pension funds that have none. The figure shows that pension funds with young trustees systematically allocate more to equity than pension funds that have none. This result is robust to different definitions of a young trustee.

model consists of executive and non-executive directors. The non-executive directors are not direct trustees of the stakeholders in the pension fund.

${ }^{10}$ Data on the Dutch labor force are available at: https://www.cbs.nl/en-gb 


\section{Figure 2-3. Strategic Equity Allocation by Board Age}

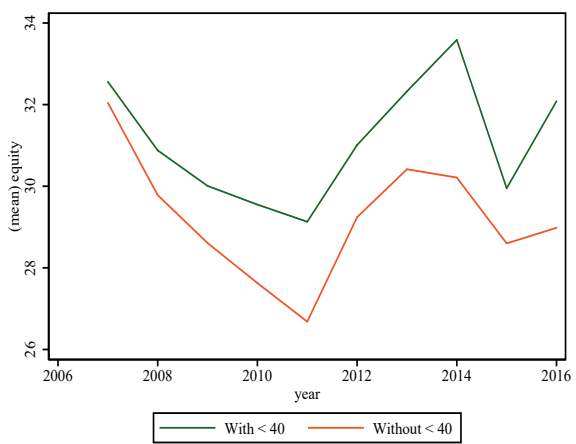

A. Avg. strategic equity allocation of pension funds with trustees younger than 40

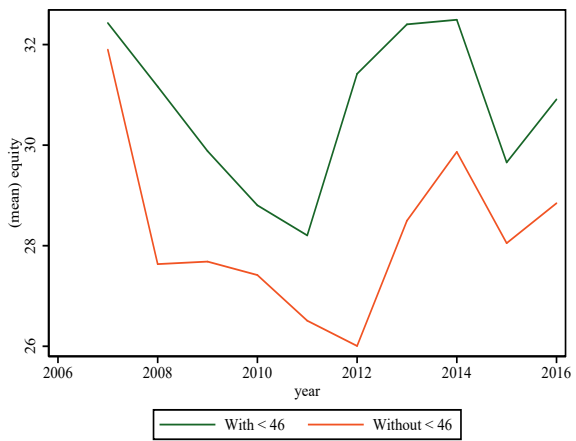

B. Average strategic equity allocation of pension funds with trustees younger than 46

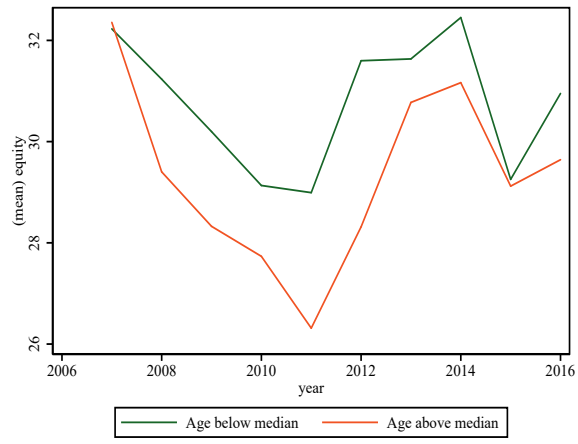

C. Avg. strategic equity allocation by median board age

Notes: Panel A (B) shows the average strategic equity allocation of pension funds that at the end of each year, have or do not have at least one trustee younger than 40 (46) years old on their board. Panel C shows the average strategic equity allocation of pension funds that at the end of each year, have an average age on the board above or below the median value of the cross-sectional average board age in that year. 
In Panel A we use the age of 40 years old as the threshold and in Panel B 46 years old. The difference in SAA persists, if we compare pension funds with an average board age above and below the median (Panel C). This univariate analysis indicates a relation between the SAA and the age distribution of the boards. However, this relation might result from fundamental differences in the characteristics of pension funds with or without young trustees. For example, some pension funds might not have a young trustee because their population of beneficiaries is relatively old and therefore the trustee's age would just reflect the average age of participants 110 In the next sections, we address this point and we show that difference in SAAs persist after controlling for pension funds' characteristics.

\section{$2.2 \quad$ Data}

In this section, we present the data that we use to test the relation between board characteristics and pension funds' SAAs. We then continue by providing summary statistics for the pension funds' investment portfolios and trustees' characteristics.

\subsubsection{Data description}

Our analysis is based on an unbalanced panel of 437 occupational pension funds that reflect almost the entire population of DB pension funds in the Netherlands over the period from 2007 through 2016. With 1,230 billion euros in assets under management at the end of 2016, these pension funds were worth 175 percent of the national GDP. A mix of mandatory industry-wide pension plans and a long tradition for corporate pension plans make the Dutch pension fund system one of the largest in the world, despite a country's population of only 17 million citizens (OECD (2019) ) ${ }^{12}$ Professional orders such as pharmacists and general practitioners save for retirement

\footnotetext{
${ }^{11}$ The correlation between average age of the board and the average age of active participants is indeed positive, although not high (0.191). Similarly, the correlation between the average age of the board and the average age of all beneficiaries is 0.028 . The correlation matrix is displayed in Table 2.10 in the Internet Appendix.

${ }^{12}$ Roughly three-quarters of all employees participate in an industry-wide pension fund and the vast majority of these pension funds are made mandatory by the Dutch government.
} 
via professional group pension funds. The data are proprietary and provided by the prudential supervisor of pension funds, De Nederlandsche Bank (DNB). The data are also free from reporting biases, because all pension funds are obliged to report to DNB.

Pension funds report their strategic and actual asset allocations; the total net return of fees in each asset class; together with the corresponding benchmark return, their funding ratio, durations of liabilities, and total assets under management on a quarterly basis. They report the information on the board of trustees on a yearly basis that includes the name, gender, age, and tenure of each individual trustee. The database also includes the stakeholder group that each trustee represents. A trustee can represent the participants (current or former employees), the retirees, or the employer (sponsor). In addition, a trustee can be appointed because of their expertise without representing a specific stakeholder. This is referred to as an independent trustee. Moreover, we have collected information about the education and previous employments of individual trustees through the social media website LinkedIn.com.

\subsubsection{Summary statistics}

Table 2.1 shows that on average, pension funds allocate 30 percent of their portfolio to equity, 60 percent to fixed income, and the remaining 10 percent to real estate, private equity, hedge funds, and commodities. These allocations are relatively stable over the sample period. An exception is during the Euro Sovereign Debt Crisis in 2011 when pension funds reduced their strategic allocation to fixed income assets in favor of equity and alternatives, see Panel A of Figure 2-4. Pension funds display an average funding ratio of 114 percent. Panel B of Figure 2-4 shows that in the early years of the sample the average funding ratio was around 140 percent, while after the Global Financial Crisis it fluctuated between 100 and 115 percent. Pension funds report an average annual equity return of 5.3 percent. However, the benchmark-adjusted return is close to zero that indicates pension funds on average do not outperform or underperform their benchmarks. Some 74 percent of the pension funds in our sample are corporate pension funds, 22 percent are industry-wide pension funds, and 
Table 2.1: Summary statistics

\begin{tabular}{|c|c|c|c|c|c|c|c|}
\hline & Obs & Mean & Std. Dev. & $\overline{\mathrm{Min}}$ & $25^{t h}$ & $75^{t h}$ & $\overline{\mathrm{Max}}$ \\
\hline \multicolumn{8}{|l|}{ A. Strategic Asset Allocation } \\
\hline Fixed Income & 2,857 & 60.38 & 14.37 & 9.00 & 50.00 & 70.00 & 100.00 \\
\hline Equity & 2,857 & 29.82 & 11.59 & 0.00 & 22.40 & 36.80 & 80.00 \\
\hline Real Estate & 2,857 & 5.74 & 5.91 & 0.00 & 0.00 & 10.00 & 51.82 \\
\hline Private Equity & 2,857 & 0.68 & 1.71 & 0.00 & 0.00 & 0.00 & 12.20 \\
\hline Hedge Funds & 2,857 & 1.11 & 2.78 & 0.00 & 0.00 & 0.00 & 40.00 \\
\hline Commodities & 2,857 & 1.02 & 2.04 & 0.00 & 0.00 & 1.30 & 22.50 \\
\hline Other Assets & 2,857 & 0.51 & 2.04 & 0.00 & 0.00 & 0.00 & 38.30 \\
\hline Cash & 2,857 & 0.70 & 3.60 & 0.00 & 0.00 & 0.00 & 90.60 \\
\hline \multicolumn{8}{|l|}{ B. Pension Funds' Characteristics } \\
\hline Funding Ratio & 2,831 & 113.83 & 28.87 & 83.60 & 100.20 & 117.40 & 323.80 \\
\hline Assets Under Management (Million) & 2,850 & 2,837 & 18,142 & 0.00 & 91.83 & 916.46 & 380,976 \\
\hline Corporate Pension Funds & 2,857 & 0.74 & 0.44 & 0.00 & 0.00 & 1.00 & 1.00 \\
\hline Industry-Wide Pension Funds. & 2,857 & 0.22 & 0.41 & 0.00 & 0.00 & 0.00 & 1.00 \\
\hline Professional Group Pension Funds. & 2,857 & 0.04 & 0.19 & 0.00 & 0.00 & 0.00 & 1.00 \\
\hline Total Yearly Return & 2,857 & 5.70 & 8.02 & -21.82 & 1.80 & 11.00 & 21.40 \\
\hline Total Bmk. Adj. Return & 2,857 & 0.02 & 2.73 & -9.20 & -0.90 & 0.80 & 9.30 \\
\hline Equity Yearly Return & 2,857 & 5.28 & 20.73 & -55.79 & 0.00 & 16.30 & 36.40 \\
\hline Equity Bmk. Adj. Return & 2857 & 0.06 & 3.11 & -12.10 & -0.90 & 0.92 & 13.20 \\
\hline Average Age Active Participants & 2,759 & 45.02 & 4.44 & 32.72 & 42.39 & 47.45 & 63.21 \\
\hline Average Age Retirees & 2,817 & 69.80 & 5.40 & 35.45 & 67.44 & 73.28 & 87.67 \\
\hline Average Age Former Participants & 2,800 & 47.31 & 4.56 & 30.21 & 44.35 & 50.19 & 67.50 \\
\hline Average Age Tot. Participants & 2,822 & 52.20 & 7.68 & 33.33 & 46.78 & 56.96 & 82.89 \\
\hline Liablity Duration & 2,781 & 17.55 & 4.21 & 6.10 & 15.00 & 19.80 & 30.10 \\
\hline \% Active Participants & 2,759 & 34.37 & 17.50 & 0.00 & 22.62 & 45.03 & 99.91 \\
\hline$\%$ Retirees & 2,817 & 24.40 & 18.43 & 0.02 & 10.93 & 34.42 & 100.00 \\
\hline$\%$ Former Participants & 2,800 & 42.37 & 17.41 & 0.01 & 30.76 & 53.77 & 100.00 \\
\hline \multicolumn{8}{|l|}{ C. Board of Trustees } \\
\hline Board Size & 2,794 & 7.10 & 2.49 & 1.00 & 6.00 & 8.00 & 20.00 \\
\hline Board Average Age & 2,736 & 53.02 & 5.65 & 26.00 & 49.75 & 56.83 & 73.00 \\
\hline Board Median Age & 2,736 & 53.00 & 6.45 & 26.00 & 49.00 & 57.50 & 73.00 \\
\hline Diff. Age Board vs. Participants & 2,669 & 7.89 & 6.43 & -27.36 & 4.18 & 12.18 & 30.21 \\
\hline Board Average Tenure & 2,764 & 5.27 & 2.88 & 0.00 & 3.25 & 6.73 & 22.75 \\
\hline$\%$ Female Trustees & 2,794 & 11.09 & 13.42 & 0.00 & 0.00 & 18.18 & 100.00 \\
\hline \% Employer Trustees & 2,794 & 45.59 & 13.63 & 0.00 & 42.86 & 50.00 & 100.00 \\
\hline \% Retirees Trustees & 2,794 & 11.58 & 12.25 & 0.00 & 0.00 & 20.00 & 100.00 \\
\hline \% Employees Trustees & 2,794 & 38.65 & 15.16 & 0.00 & 33.33 & 50.00 & 100.00 \\
\hline \% Independent Trustees & 2,794 & 3.05 & 12.36 & 0.00 & 0.00 & 0.00 & 100.00 \\
\hline \% Former Employees Trustees & 2,794 & 0.60 & 5.24 & 0.00 & 0.00 & 0.00 & 100.00 \\
\hline$\%$ Young Trustees $($ Age $<40)$ & 2,736 & 8.97 & 12.50 & 0.00 & 0.00 & 16.67 & 100.00 \\
\hline \% Young Trustees $($ Age $<46)$ & 2,736 & 19.00 & 17.12 & 0.00 & 0.00 & 28.57 & 100.00 \\
\hline \% University Degree & 2,794 & 36.23 & 26.01 & 0.00 & 16.67 & 50.00 & 100.00 \\
\hline$\%$ Public Background & 2,794 & 7.48 & 15.21 & 0.00 & 0.00 & 0.00 & 100.00 \\
\hline$\%$ Finance Background & 2,794 & 18.23 & 18.98 & 0.00 & 0.00 & 28.57 & 100.00 \\
\hline
\end{tabular}

Notes: Panel A presents the information about pension funds' strategic asset allocation, Panel B about pension funds' characteristics, and Panel $\mathrm{C}$ about the boards of trustees. The mean and standard deviation are measured across pension funds and over time for each variable. All numbers are expressed as percentages unless otherwise stated and are computed relying on yearly information. Quarterly returns are compounded to obtain yearly returns. The strategic asset allocation, funding ratio, and the assets under management figures are based on the reported values in the last quarter of each year. For some of the variables, e.g., assets under management, the allocation to hedge funds and private equity, the mean is outside the 25-75 percent interval. This is due to the skewness of the distribution. In column Max exceptionally high values are reported for hedge funds, commodities, other assets, and cash. These are special cases of pension funds that are in a process of liquidation or a merger. These temporary high values are not persistent over time and do not affect the results of our analysis.

4 percent are professional group pension funds. The average assets under management is close to 3 billion euros. The sample contains a small number of very large pension funds. 
The population of participants is as follows: On average 34 percent are active participants, and 42 percent are former participants. The large group of former participants shows that many employees that change jobs do not transfer their accrued pension benefits to a new pension fund ${ }^{13}$ The retirees represent 24 percent. The average age of active participants is 45 years old while the average age of all beneficiaries (participants and retirees) is 52 years old. The average age of board members is 54 years old; thus, it is higher than the average ages of both active participants and the total beneficiaries. The average share of board members younger than 40 years is 9 percent, which is less than one trustee per board. The age of 40 corresponds to the code of Dutch pension funds. The percentage of board members that is younger than 46 years old is only 19 percent. The age of 46 years corresponds to the 25 th percentile of the age distribution of all individual trustees in the sample 14 Given that an average board has seven members, this percentage means that approximately one out of seven trustees on an average board is young. The average share of female trustees is 11 percent. These statistics provide evidence of the fact that both the young and female populations are under-represented. The average share of trustees representing employers on the board is 45 percent, the share of trustees representing active participants is 39 percent, and the share of trustees representing retirees is 11 percent. The average share of independent trustees on the board grew from 1.6 percent in 2007 to 9 percent in 2016. Some 36 percent of trustees has a university degree, 7 percent has a public sector background, and 18 percent has a financial background. We consider a trustee as having a financial background if they work or have worked in fields such as finance and accounting, or at an economics related institution. A trustee has a public sector background if they have worked for government institutions, municipalities, labor unions, or at other social institutions as well as in health care.

\footnotetext{
${ }^{13}$ Transferring accrued pension benefits requires active decision-making by individuals. A great deal of research has shown that people procrastinate when making complex financial decisions (Madrian and Shea (2001), Frederick et al. (2002)).

${ }^{14}$ This distribution is not observable from Table 2.1 that provides summary statistics at the pension fund level. Summary statistics at the trustee level are available in Table 2.9 of the Internet Appendix.
} 
Figure 2-4. Pension fund asset allocation and funding ratio over time

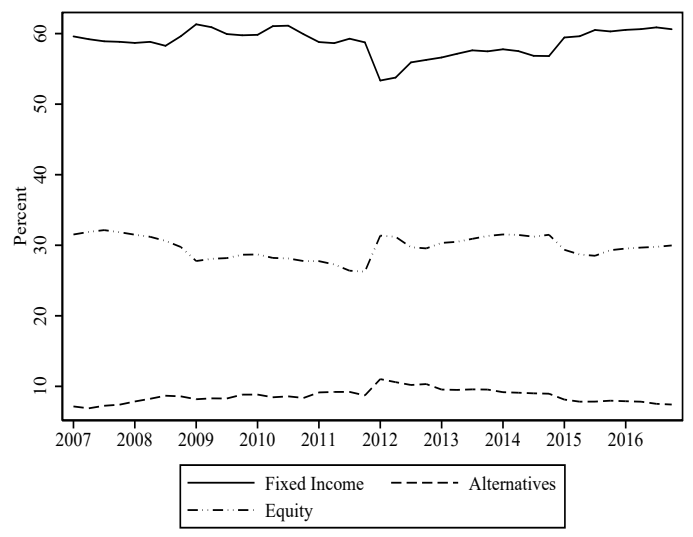

A. Avg. strategic asset allocation over time

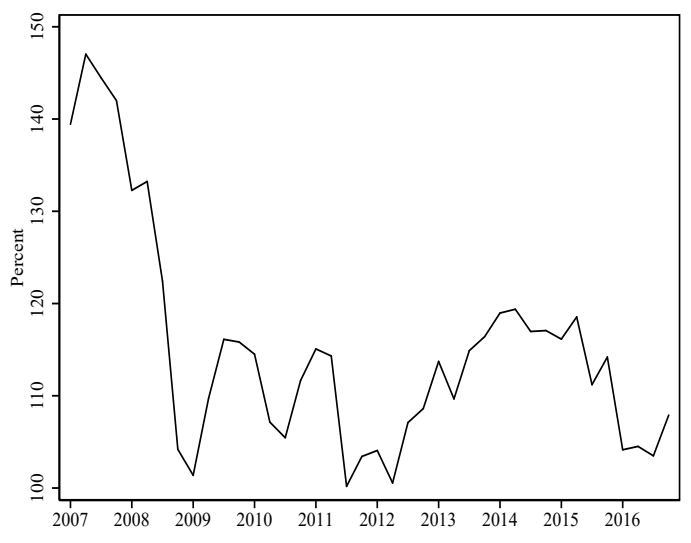

B. Avg. funding ratio over time

Notes: Panel A in the figure shows how the average SAA to equity, alternative assets, and fixed income has evolved over time. Alternative assets include real estate, private equity, hedge funds, and commodities. Panel B shows the evolution of the average funding ratio across pension funds.

\subsection{Hypotheses and model}

In this section, we summarize the hypotheses and the model that we use to test the hypotheses. 


\subsubsection{Hypotheses}

The boards in our sample have the fiduciary duty to invest in the best interest of the plan beneficiaries and to do this in a highly regulated environment. First, we hypothesize that their characteristics, in particular their age and gender, should not matter in designing the SAA. Hence, no relation should exist between trustees' characteristics and their investment decisions. Although there is empirical evidence that indicates young investors have preferences for riskier allocations (Calvet et al. (2007); Dohmen et al. (2017) ) and females are more risk averse than males (Bruce and Johnson (1994); Sunden and Surette (1998); Bernasek and Shwiff (2001); Faccio et al. (2016)), these characteristics should not matter for the investment decisions made by trustees on behalf of others. If trustees consider their own characteristics in making these decisions, they might design SAAs that do not reflect the characteristics and preferences of the pension plan's beneficiaries. However, it is important to stress that board characteristics might be endogenous. Endogeneity may arise if board members are elected in such a way to reflect the characteristics of the participants. For example, pension funds with many young participants might have board members that are on average younger than pension funds with old participants. The correlation between the average age of participants and the average age of board members is 0.19 , and the correlation between the average age of all beneficiaries and the average age of board members is 0.30 . These positive but low correlations indicate that the relation between board characteristics and SAAs is not simply a reflection of beneficiaries' characteristics.

Second, we hypothesize that stakeholder representation should not affect the SAA. Even though trustees are elected by a stakeholder group, once elected, they must act in the best interest of the pension plan's beneficiaries. Therefore, we expect to find no relation between the share of the different stakeholder trustees on the board and strategic investment decisions. Yet, in pension funds in which employer trustees have more power than the trustees of active participants, board decisions might be tilted towards the interests of the employer. For example, a higher equity exposure 
increases the value of the employer's claim on excess assets in cases of overfunding. Safeguarding the interests of their constituencies can ultimately be beneficial to trustees' career paths. Hence, if they value their own career paths over beneficiaries' interests, trustees can generate a principal-agent problem between themselves and the beneficiaries (Cocco and Volpin (2007)).

We complement these two hypotheses by studying the effect of board characteristics on the strategic allocation to alternative asset classes and on equity portfolio returns. Following Figure 2-3, we hypothesize that young trustees favor riskier SAAs. Therefore, we expect the strategic allocation to alternative asset classes to be positively correlated with the share of young trustees on the board. Another way in which pension funds could take more risk is by allocating more to active equity mandates. Provided that skilled equity managers are selected, this allocation will translate into higher benchmark-adjusted performance. Therefore, we expect to observe a positive correlation between the equity benchmark-adjusted performance and the hiring of young trustees, which is the only factor that makes the share of young trustees increase over time.

\subsubsection{Model}

To test our hypotheses, we rely on the following pooled OLS model:

$$
y_{i, t}=\alpha+X_{i, t} \beta+Z_{i, t} \gamma+\theta_{t}+\epsilon_{i, t}
$$

where the dependent variable $y_{i, t}$ is the strategic equity allocation of pension fund $i$ at the end of year $t$, and $Z_{i, t}$ is a set of board characteristics. Specifically we consider several measures of the board's average age, size, and tenure of its members as well as the percentage of female trustees, percentage of employer trustees, the percentage of retirees' trustees, and the percentage of independent trustees. The percentage of trustees who represent the participants is the omitted category ${ }^{15}$ We also include

\footnotetext{
${ }^{15}$ Note that we sum the percentage of trustees who represent active participants with the percentage of trustees who represent former participants. Only very few pension funds have these trustees representing former participants.
} 
the percentage of trustees holding a university degree and the percentage of trustees having a public sector background and the percentage of trustees with a finance background.

Variable $X_{i, t}$ comprises a number of pension fund characteristics that are key determinants of the SAA, such as the average age of active participants, the percentage of retirees over the total number of beneficiaries, the natural logarithm of the total assets under management, and the funding ratio. The funding ratio is related to the pension fund's risk profile and to the portfolio performance, and it is therefore lagged by one year to avoid endogeneity concerns. We also take into consideration the level of interest rate risk hedging for each pension fund through the so-called swap ratio. Pension funds typically hedge a part of interest rate risk using interest rate swaps. The interest rate risk is inherent to the present value of a pension benefit that is being determined by discounting the accrued pension benefits against the prevailing market interest rates. The swap ratio is the fraction of interest rate risk that is being hedged using interest rate swaps. We need to calculate the swap ratio because it is not a variable in regulatory reporting. In Section $2 . \mathrm{A}$ we provide a detailed derivation of how we approximate the swap ratio in a similar fashion as in Broeders et al. (2020). We also correct for the type of pension fund by including dummies for professional group pension funds and industry-wide pension funds. Corporate pension funds are the omitted category. Finally, $\theta_{t}$ in $(2.1)$ is a set of year dummies that control for the economic conditions that might affect investment decisions in a given year.

We expect pension funds to follow a life-cycle investment strategy (Campbell and Viceira (2002)). Thus, we expect the strategic equity allocation to be negatively related to the average age of active participants. Young plan participants have a high implicit exposure to fixed income via their human capital and prefer to invest a large part of their financial capital in equities ${ }^{16}$ We expect large pension funds to invest more in equities due to economies of scale that allows them to attract skilled asset management firms (Bikker and De Dreu (2009); Dyck and Pomorski (2011); Broeders et al. $(2016 \mathrm{~b})$ ). The relation between the funding ratio of pension funds and their

\footnotetext{
${ }^{16}$ Hereby, we implicitly assume that human capital is an asset with low risk.
} 
allocation to equity can be twofold. On the one hand, underfunded pension funds may decide to manage their risk and hence reduce their exposure to equity. On the other hand, pension funds with a low funding ratio may shift the risk of underfunding to the beneficiaries and increase the allocation to equity $(\operatorname{Rauh}(2009))$, that is, gamble for resurrection. In line with Broeders et al. (2020), we expect that the hedging of interest rate risk does not affect the strategic equity allocation. This non-effect comes from two opposing mechanisms that roughly cancel each other out. On the one hand, pension funds that hedge interest rate risk using interest rate swaps have a lower exposure to interest rate risk. This hedging means that they can increase their exposure to other risk factors such as equity. On the other hand, pension funds that hedge interest rate risk using interest rate swaps have a higher liquidity demand from collateral requirements. This demand means that these pension funds can invest less in risky assets.

\subsection{Board characteristics and strategic equity allo- cation}

In this section, we present our key results for board characteristics. First, we run a baseline model with only pension fund characteristics. Second, we show that trustees consider their own age when they design the strategic equity allocation of the pension funds in which they are appointed. Third, we report that other trustees' characteristics such as gender and financial background impact the strategic equity allocation. Fourth, we document that the impact of age is present mainly in corporate pension funds. This suggests that some of the governance features of corporate pension funds might encourage trustees to value their own characteristics.

\subsubsection{Baseline model}

We present the results of Equation (2.1) for all pension funds in Table 2.2. We begin with a baseline model in Column (1) in which only the pension funds' characteristics 
Table 2.2: The effect of board characteristics on the strategic equity allocation

\begin{tabular}{|c|c|c|c|c|c|}
\hline & $(1)$ & $(2)$ & (3) & (4) & (5) \\
\hline Board Average Age & & $\begin{array}{c}-0.265^{* * *} \\
(-3.29)\end{array}$ & & & \\
\hline Board Median Age & & & $\begin{array}{c}-0.237^{* * *} \\
(-3.37)\end{array}$ & & \\
\hline$\%$ Young Trustees (Age $<46$ ) & & & & $\begin{array}{c}0.051^{* *} \\
(2.08)\end{array}$ & \\
\hline$\%$ Young Trustees (Age $<40$ ) & & & & & $\begin{array}{l}0.060^{*} \\
(1.90)\end{array}$ \\
\hline Board Size & & $\begin{array}{c}0.220 \\
(0.97)\end{array}$ & $\begin{array}{l}0.218 \\
(0.97)\end{array}$ & $\begin{array}{l}0.226 \\
(0.99)\end{array}$ & $\begin{array}{c}0.236 \\
(1.04)\end{array}$ \\
\hline Board Average Tenure & & $\begin{array}{l}0.167 \\
(1.02)\end{array}$ & $\begin{array}{l}0.161 \\
(0.98)\end{array}$ & $\begin{array}{l}0.138 \\
(0.84)\end{array}$ & $\begin{array}{l}0.132 \\
(0.80)\end{array}$ \\
\hline$\%$ Female Trustees & & $\begin{array}{c}-0.055^{*} \\
(-1.91)\end{array}$ & $\begin{array}{c}-0.056^{*} \\
(-1.92)\end{array}$ & $\begin{array}{c}-0.051^{*} \\
(-1.79)\end{array}$ & $\begin{array}{c}-0.049^{*} \\
(-1.72)\end{array}$ \\
\hline \% Employer Trustees & & $\begin{array}{l}0.046 \\
(1.34)\end{array}$ & $\begin{array}{l}0.046 \\
(1.33)\end{array}$ & $\begin{array}{l}0.054 \\
(1.53)\end{array}$ & $\begin{array}{l}0.054 \\
(1.52)\end{array}$ \\
\hline$\%$ Retirees Trustees & & $\begin{array}{l}0.013 \\
(0.31)\end{array}$ & $\begin{array}{l}0.009 \\
(0.20)\end{array}$ & $\begin{array}{l}0.005 \\
(0.12)\end{array}$ & $\begin{array}{l}0.005 \\
(0.12)\end{array}$ \\
\hline$\%$ Independent Trustees & & $\begin{array}{l}0.007 \\
(0.27)\end{array}$ & $\begin{array}{l}0.008 \\
(0.27)\end{array}$ & $\begin{array}{l}0.009 \\
(0.32)\end{array}$ & $\begin{array}{l}0.010 \\
(0.35)\end{array}$ \\
\hline$\%$ University Degree & & $\begin{array}{l}0.024 \\
(0.94)\end{array}$ & $\begin{array}{l}0.024 \\
(0.92)\end{array}$ & $\begin{array}{l}0.024 \\
(0.92)\end{array}$ & $\begin{array}{l}0.026 \\
(0.98)\end{array}$ \\
\hline$\%$ Public Background & & $\begin{array}{l}0.002 \\
(0.04)\end{array}$ & $\begin{array}{l}0.004 \\
(0.10)\end{array}$ & $\begin{array}{l}-0.001 \\
(-0.02)\end{array}$ & $\begin{array}{l}-0.002 \\
(-0.05)\end{array}$ \\
\hline$\%$ Finance Background & & $\begin{array}{c}-0.082^{* *} \\
(-2.51)\end{array}$ & $\begin{array}{c}-0.084^{* * *} \\
(-2.61)\end{array}$ & $\begin{array}{c}-0.079^{* *} \\
(-2.40)\end{array}$ & $\begin{array}{c}-0.076^{* *} \\
(-2.31)\end{array}$ \\
\hline Average Age Active Participants & $\begin{array}{c}-0.361^{* * *} \\
(-2.62)\end{array}$ & $\begin{array}{c}-0.324^{* *} \\
(-2.41)\end{array}$ & $\begin{array}{c}-0.326^{* *} \\
(-2.44)\end{array}$ & $\begin{array}{c}-0.335^{* *} \\
(-2.50)\end{array}$ & $\begin{array}{c}-0.334^{* *} \\
(-2.51)\end{array}$ \\
\hline$\%$ Retirees & $\begin{array}{l}0.034 \\
(0.76)\end{array}$ & $\begin{array}{l}0.025 \\
(0.57)\end{array}$ & $\begin{array}{l}0.023 \\
(0.54)\end{array}$ & $\begin{array}{l}0.017 \\
(0.39)\end{array}$ & $\begin{array}{l}0.015 \\
(0.35)\end{array}$ \\
\hline Log Size & $\begin{array}{c}0.752^{* * *} \\
(2.69)\end{array}$ & $\begin{array}{c}0.753^{* *} \\
(2.15)\end{array}$ & $\begin{array}{c}0.748^{* *} \\
(2.16)\end{array}$ & $\begin{array}{c}0.724^{* *} \\
(2.05)\end{array}$ & $\begin{array}{c}0.687^{*} \\
(1.92)\end{array}$ \\
\hline Lag Funding Ratio & $\begin{array}{c}0.058^{* * *} \\
(2.81)\end{array}$ & $\begin{array}{c}0.061^{* * *} \\
(2.87)\end{array}$ & $\begin{array}{c}0.060^{* * *} \\
(2.87)\end{array}$ & $\begin{array}{c}0.058^{* * *} \\
(2.74)\end{array}$ & $\begin{array}{c}0.059^{* * *} \\
(2.82)\end{array}$ \\
\hline Swap Ratio & $\begin{array}{l}0.031 \\
(1.50)\end{array}$ & $\begin{array}{l}0.029 \\
(1.34)\end{array}$ & $\begin{array}{l}0.030 \\
(1.39)\end{array}$ & $\begin{array}{l}0.029 \\
(1.38)\end{array}$ & $\begin{array}{l}0.030 \\
(1.44)\end{array}$ \\
\hline Professional group Pension Funds & $\begin{array}{c}-4.378^{* *} \\
(-2.39)\end{array}$ & $\begin{array}{l}-3.611 \\
(-1.59)\end{array}$ & $\begin{array}{l}-3.633 \\
(-1.60)\end{array}$ & $\begin{array}{l}-3.388 \\
(-1.49)\end{array}$ & $\begin{array}{l}-3.264 \\
(-1.41)\end{array}$ \\
\hline Industry-Wide Pension Funds & $\begin{array}{c}-3.578^{* * *} \\
(-2.71)\end{array}$ & $\begin{array}{c}-4.086^{* *} \\
(-2.35)\end{array}$ & $\begin{array}{c}-4.089^{* *} \\
(-2.34)\end{array}$ & $\begin{array}{c}-4.304^{* *} \\
(-2.47)\end{array}$ & $\begin{array}{c}-4.316^{* *} \\
(-2.47)\end{array}$ \\
\hline Constant & $\begin{array}{c}33.972^{* * *} \\
(4.93) \\
\end{array}$ & $\begin{array}{c}41.508^{* * *} \\
(5.35) \\
\end{array}$ & $\begin{array}{c}40.525^{* * *} \\
(5.36) \\
\end{array}$ & $\begin{array}{c}28.637^{* * *} \\
(3.91) \\
\end{array}$ & $\begin{array}{c}29.354^{* * *} \\
(3.96) \\
\end{array}$ \\
\hline Time Dummies & Yes & Yes & Yes & Yes & Yes \\
\hline Observations & 2,456 & 2,392 & 2,392 & 2,392 & 2,392 \\
\hline$R^{2}$ & 0.07 & 0.096 & 0.097 & 0.090 & 0.089 \\
\hline
\end{tabular}

Notes: The table shows the results for the pooled OLS in Equation 2.1: $y_{i, t}=\alpha+X_{i, t} \beta+Z_{i, t} \gamma+\theta_{t}+\epsilon_{i, t}$. The dependent variable $y_{i, t}$ is the strategic equity allocation of pension fund $i$ in year $t . X_{i, t}$ is a set of pension fund characteristics, $Z_{i, t}$ is a set of board characteristics, and $\theta_{t}$ is the year fixed effect. Column (1) displays the results for the baseline model in which only pension funds' characteristics are included. Columns (2) - (5) display the model estimated including the board characteristics. We consider four different specification of the age distribution in the board of trustees, namely the average age among the trustees, the median age of the board, the share of trustees younger than 46 years old, and the share of trustees younger than 40 years old. Standard errors are clustered at the pension fund level to correct for serial correlation. $t$ statistics in parentheses. ${ }^{*} p<0.1,{ }^{* *} p<0.05,{ }^{* * *} p<0.01$. 
are included. In line with our predictions, we observe that the average age of active participants is negatively related with the strategic equity allocation. Pension funds with, on average, one year older active participants allocate 0.36 percentage points less to equity than pension funds with younger participants. This is in line with Bikker et al. (2012) who find a coefficient of 0.39. Our finding indicates that on average, pension funds indeed apply a life-cycle investment strategy. The coefficient for the fraction of retirees is not statistically different from zero. We argue that this insignificance follows from the fact that the average age of active participants is also informative about the fraction of retirees. In Section 2.B we provide a technical explanation of this argument. Large pension funds allocate more to equity than small pension funds, which follows our economies of scale argument. We also show that the lagged funding ratio is positively related to the strategic equity allocation. This relation indicates that pension funds with a high funding ratio take more investment risk. The swap ratio has no effect on the strategic equity allocation. This is in line with our expectation. Hedging interest rate risk with swaps has two effects that roughly cancel each other out. On the one hand this hedging creates the opportunity to take more risks elsewhere, on the other hand using swaps to hedge this risk requires a pension fund to hold more risk-free assets such as cash and short-term government bonds for collateral purposes. Finally, we find that industry-wide pension funds and professional group pension funds invest less in equities compared to corporate pension funds.

\subsubsection{Relation between board age and strategic equity alloca- tion}

Next, we add board characteristics to the model. Columns (2) - (5) in Table 2.2 contain our main results about the effect of board age on the strategic equity allocation. In contrast to our main hypotheses, we find a statistically significant age effect. Based on Column (2), pension funds with more older trustees allocate less to equity compared to pension funds with younger trustees on the board. A one standard devi- 
ation higher average age of the board of trustees is related to a 1.5 percentage point lower strategic equity allocation. We also assess the impact of the median board age in Column (3). Pension funds make decisions on a majority basis, and the median voter on the board plays a decisive role in approving any decision (Hotelling (1929)). In Section 2.C we describe how the so-called median-voter theorem applies to the decision-making of pension fund boards. Furthermore, the median age is less affected by outliers than the average age. Column (3) displays the results. In line with the previous finding, pension funds with a one standard deviation higher median board age make a 1.5 percentage point lower equity allocation.

Not only the mean or median age of the board matters, but also the age distribution of the board. Young trustees may be able to provide countervailing power in a board of a generally high average age. Column (4) displays the estimation results of a model that includes the fraction of trustees younger than 46 years old on the board. Pension funds with an average board size of seven members of which one trustee is younger than 46 years old display a strategic equity allocation that is 0.7 percentage points higher than pension funds that have no young trustees on their boards ${ }^{17}$ If we use the fraction of trustees younger than 40 years old, the strategic equity allocation is 0.8 percentage points higher, although the latter effect is only borderline significant 18

To investigate the distribution of board age further, we use the observation from Table 2.1 that the difference between the average age of board members and the average age of active participants can be large. On average this difference, in fact, is almost eight years. Therefore, we test how this difference affects the strategic equity allocation by adding one additional variable to Equation (2.1) that we call the age-representation gap. This variable equals one if the difference between the

\footnotetext{
${ }^{17}$ One trustee out of 7 corresponds to 14 percent of the board members in an average board. Therefore, pension funds that have one trustee younger than 46 years old display a 14 percent higher share of young trustees with respect to pension funds that have none $(14 \times 0.05=0.7)$.

${ }^{18}$ In Table 2.13, I test the impact of board age on the risky assets allocation. Risky assets is the sum of equity, hedge funds, commodities, private equity and real estate. The results are in line with the analysis performed on the equity allocation only. The variables capturing the percentage of young trustees are not statistically significant, although the magnitude of the coefficients is in line with the coefficients in Table 2.2
} 


\section{Table 2.3: The effect of young trustees on the strategic equity allocation}

\begin{tabular}{|c|c|c|c|c|}
\hline & $(1)$ & $(2)$ & $(3)$ & $(4)$ \\
\hline Age Representation Gap & $\begin{array}{c}-2.418^{* * *} \\
(-2.79)\end{array}$ & $\begin{array}{c}-3.699^{* * *} \\
(-3.11)\end{array}$ & $\begin{array}{c}-2.503^{* * *} \\
(-2.87)\end{array}$ & $\begin{array}{c}-3.318^{* * *} \\
(-3.31)\end{array}$ \\
\hline$\%$ Young Trustees $($ Age $<46)$ & $\begin{array}{l}0.022 \\
(0.85)\end{array}$ & $\begin{array}{l}0.001 \\
(0.05)\end{array}$ & & \\
\hline Age Representation Gap $\times \%$ Young Trustees $($ Age $<46)$ & & $\begin{array}{l}0.097^{*} \\
(1.76)\end{array}$ & & \\
\hline$\%$ Young Trustees $($ Age $<40)$ & & & $\begin{array}{l}0.032 \\
(0.96)\end{array}$ & $\begin{array}{l}0.007 \\
(0.20)\end{array}$ \\
\hline Age Representation Gap $\times \%$ Young Trustees $($ Age $<40)$ & & & & $\begin{array}{l}0.141^{*} \\
(1.70)\end{array}$ \\
\hline Board Size & $\begin{array}{l}0.219 \\
(0.98)\end{array}$ & $\begin{array}{l}0.218 \\
(0.98)\end{array}$ & $\begin{array}{l}0.223 \\
(1.00)\end{array}$ & $\begin{array}{l}0.232 \\
(1.05)\end{array}$ \\
\hline Board Average Tenure & $\begin{array}{l}0.155 \\
(0.95)\end{array}$ & $\begin{array}{l}0.149 \\
(0.93)\end{array}$ & $\begin{array}{l}0.158 \\
(0.97)\end{array}$ & $\begin{array}{l}0.147 \\
(0.92)\end{array}$ \\
\hline$\%$ Female Trustees & $\begin{array}{l}-0.051^{*} \\
(-1.82)\end{array}$ & $\begin{array}{l}-0.050^{*} \\
(-1.78)\end{array}$ & $\begin{array}{l}-0.051^{*} \\
(-1.81)\end{array}$ & $\begin{array}{l}-0.050^{*} \\
(-1.78)\end{array}$ \\
\hline \% Employer Trustees & $\begin{array}{c}0.048 \\
(1.39)\end{array}$ & $\begin{array}{l}0.049 \\
(1.40)\end{array}$ & $\begin{array}{l}0.048 \\
(1.40)\end{array}$ & $\begin{array}{c}0.048 \\
(1.37)\end{array}$ \\
\hline \% Retirees Trustees & $\begin{array}{l}0.013 \\
(0.31)\end{array}$ & $\begin{array}{l}0.013 \\
(0.30)\end{array}$ & $\begin{array}{l}0.015 \\
(0.34)\end{array}$ & $\begin{array}{l}0.016 \\
(0.38)\end{array}$ \\
\hline \% Independent Trustees & $\begin{array}{l}0.012 \\
(0.44)\end{array}$ & $\begin{array}{l}0.011 \\
(0.39)\end{array}$ & $\begin{array}{l}0.013 \\
(0.47)\end{array}$ & $\begin{array}{l}0.013 \\
(0.47)\end{array}$ \\
\hline$\%$ University Degree & $\begin{array}{l}0.024 \\
(0.93)\end{array}$ & $\begin{array}{l}0.026 \\
(1.01)\end{array}$ & $\begin{array}{l}0.025 \\
(0.95)\end{array}$ & $\begin{array}{l}0.025 \\
(0.98)\end{array}$ \\
\hline \% Public Background & $\begin{array}{l}-0.000 \\
(-0.01)\end{array}$ & $\begin{array}{l}-0.005 \\
(-0.11)\end{array}$ & $\begin{array}{l}-0.001 \\
(-0.01)\end{array}$ & $\begin{array}{l}-0.004 \\
(-0.08)\end{array}$ \\
\hline$\%$ Finance Background & $\begin{array}{c}-0.081^{* *} \\
(-2.48)\end{array}$ & $\begin{array}{c}-0.081^{* *} \\
(-2.50)\end{array}$ & $\begin{array}{c}-0.081^{* *} \\
(-2.46)\end{array}$ & $\begin{array}{c}-0.080^{* *} \\
(-2.47)\end{array}$ \\
\hline Average Age Active Participants & $\begin{array}{c}-0.482^{* * *} \\
(-3.55)\end{array}$ & $\begin{array}{c}-0.465^{* * *} \\
(-3.51)\end{array}$ & $\begin{array}{c}-0.483^{* * *} \\
(-3.50)\end{array}$ & $\begin{array}{c}-0.471^{* * *} \\
(-3.51)\end{array}$ \\
\hline$\%$ Retirees & $\begin{array}{l}0.021 \\
(0.50)\end{array}$ & $\begin{array}{l}0.019 \\
(0.46)\end{array}$ & $\begin{array}{l}0.020 \\
(0.47)\end{array}$ & $\begin{array}{l}0.016 \\
(0.40)\end{array}$ \\
\hline Log Size & $\begin{array}{c}0.710^{* *} \\
(2.03)\end{array}$ & $\begin{array}{c}0.698^{* *} \\
(2.00)\end{array}$ & $\begin{array}{c}0.707^{* *} \\
(2.00)\end{array}$ & $\begin{array}{c}0.699^{* *} \\
(1.98)\end{array}$ \\
\hline Lag Funding Ratio & $\begin{array}{c}0.060^{* * *} \\
(2.84)\end{array}$ & $\begin{array}{c}0.058^{* * *} \\
(2.80)\end{array}$ & $\begin{array}{c}0.060^{* * *} \\
(2.87)\end{array}$ & $\begin{array}{c}0.057^{* * *} \\
(2.81)\end{array}$ \\
\hline Swap Ratio & $\begin{array}{l}0.027 \\
(1.28)\end{array}$ & $\begin{array}{l}0.026 \\
(1.24)\end{array}$ & $\begin{array}{l}0.027 \\
(1.30)\end{array}$ & $\begin{array}{l}0.025 \\
(1.20)\end{array}$ \\
\hline Professional Pension Funds. & $\begin{array}{l}-3.359 \\
(-1.49)\end{array}$ & $\begin{array}{l}-3.192 \\
(-1.39)\end{array}$ & $\begin{array}{l}-3.308 \\
(-1.46)\end{array}$ & $\begin{array}{l}-3.177 \\
(-1.36)\end{array}$ \\
\hline Industry Pension Funds. & $\begin{array}{c}-3.855^{* *} \\
(-2.23)\end{array}$ & $\begin{array}{c}-3.743^{* *} \\
(-2.18)\end{array}$ & $\begin{array}{c}-3.828^{* *} \\
(-2.21)\end{array}$ & $\begin{array}{c}-3.692^{* *} \\
(-2.16)\end{array}$ \\
\hline Constant & $\begin{array}{c}36.374^{* * *} \\
(4.88) \\
\end{array}$ & $\begin{array}{c}36.503^{* * *} \\
(4.91) \\
\end{array}$ & $\begin{array}{c}36.541^{* * *} \\
(4.79) \\
\end{array}$ & $\begin{array}{c}36.794^{* * *} \\
(4.84) \\
\end{array}$ \\
\hline Time Dummies & Yes & Yes & Yes & Yes \\
\hline Observations & 2392 & 2392 & 2392 & 2392 \\
\hline$R^{2}$ & 0.096 & 0.099 & 0.096 & 0.100 \\
\hline
\end{tabular}

Notes: The table shows a pooled OLS in Equation 2.1 : $y_{i, t}=\alpha+X_{i, t} \beta+Z_{i, t} \gamma+\theta_{t}+\epsilon_{i, t}$. The dependent variable $y_{i, t}$ is the portfolio share of equity for pension fund $i$ in year $t$. $X_{i, t}$ is the set of pension fund characteristics, $Z_{i, t}$ is the set of board characteristics, and $\theta_{t}$ is the year fixed effect. We add a control variable, namely the age representation gap. This is a dummy variable that equals one when pension funds display a difference of 10 years or more between the average age of the active participants and the average age of the board. This dummy is then interacted with the share of young trustees on the board to capture their behavior in funds with a large age-representation gap. The estimation relies on standard errors clustered at the pension fund level to correct for serial correlation. $t$ statistics in parentheses. ${ }^{*} p<0.1,{ }^{* *} p<0.05,{ }^{* * *} p<0.01$. 
average age of board members and the average age of the active participants exceeds 10 years, and zero otherwise ${ }^{19}$ In practice, the age-representation gap captures the effect of having a relatively old board vis-a-vis the active participants. Therefore, the age-representation gap highlights pension funds in which the characteristics of the average trustee are very distinct from the characteristics of the average participant.

Table 2.3 presents the results for the age-representation gap. Column (1) shows that pension funds that have more than 10 years difference between the average age of the board and the average age of active participants allocate 2.4 percentage points less to equity than pension funds with a smaller age-representation gap. Furthermore, adding the age-representation gap to the regression eliminates the effect of the fraction of young trustees in the board. This elimination follows from the fact that board members are generally older than the average active participant, and it is further evidence that supports the finding that board members value their own age while carrying out their fiduciary duty.

In column (2), we add an interaction term between the age-representation gap and the share of young trustees on the board. The results show that pension funds with a large age-representation gap and one additional trustee younger than 46 years old allocate 1.4 percentage points more to equity than other pension funds with a large age-representation $\left(1.4=(0.001+0.097)^{*} 14\right)$. Therefore, young trustees on relatively old boards support investment strategies that are more in line with participants' characteristics. This partially offsets the negative effect of the age-representation gap on the strategic equity allocation. Given that the age of young trustees is closer to the average age of active participants, young trustees are more likely to act in line with their own characteristics when executing their fiduciary duty. We are not able to distinguish whether young trustees just execute their fiduciary duty, value their own age, or a mix of the two. After all, we show that young trustees attenuate the distortion that old boards have on the strategic equity allocation of pension funds with relatively young active participants. Columns (3) - (4) display the analysis carried

\footnotetext{
${ }^{19}$ We use 10 years because it corresponds to the 66 th percentile of the distribution of the difference between the average board age and the average age of active participants.
} 
out with the share of trustees younger than 40 years old. The results are similar to the analysis that relies on the share of trustees younger than 46 years old.

\subsubsection{Relation between gender and financial background and strategic equity allocation}

In addition to the age effect, we also find some evidence of a gender effect. In all specifications in Table 2.2 we find that pension funds with a higher share of female trustees allocate less to equity. However, the evidence of a gender effect is not conclusive, as the coefficients are only significant at the 10 percent level. However, we must consider that, on average, boards display less than one female member, and many pension funds have no female trustees over the entire sample period. Therefore, the existence of a gender effect indicates that female trustees might not be a silent minority.

We also find in Table 2.2 and Table 2.3 that the share of trustees with a financial background is negatively related to the strategic equity allocation. This relation indicates that trustees with more financial expertise prefer to match assets and liabilities by investing more in fixed income. In line with this, Table 2.14 in the Internet Appendix shows that the share of trustees with a financial background is positively related to the strategic allocation to fixed income ${ }^{20}$

\subsubsection{Corporate versus non-corporate pension funds}

Our empirical analysis so far indicates that trustees consider their age in designing the SAAs of pension funds. Yet, why trustees would act in such a way is not clear. For example, trustees may have a direct stake in the pension fund, hence they might try to design a SAA that is more in line with their own life cycle. One way to identify this effect is through the type of pension fund. Trustees can be appointed to manage a pension fund in which they are themselves beneficiaries. In this case,

\footnotetext{
${ }^{20}$ Table 2.15 of the Internet Appendix tests the effect of the age-representation gap on the fixed income allocation. Tables 2.16 and 2.17 in the Internet Appendix show the relation between board characteristics and fixed income allocations in corporate and non-corporate pension funds.
} 
Table 2.4: Board characteristics and equity allocation in corporate pension funds

\begin{tabular}{|c|c|c|c|c|c|c|}
\hline & $(1)$ & $(2)$ & (3) & $(4)$ & (5) & $(6)$ \\
\hline Board Average Age & & $\begin{array}{c}-0.325^{* * *} \\
(-3.55)\end{array}$ & & & & \\
\hline$\%$ Young Trustees $($ Age $<46$ ) & & & $\begin{array}{c}0.057^{* *} \\
(2.02)\end{array}$ & $\begin{array}{l}-0.006 \\
(-0.19)\end{array}$ & & \\
\hline Age Representation Gap & & & & $\begin{array}{c}-5.296 * * * \\
(-3.73)\end{array}$ & & $\begin{array}{c}-4.461^{* * *} \\
(-3.71)\end{array}$ \\
\hline Age Repr. Gap×\%Young Trus. $(<46)$ & & & & $\begin{array}{c}0.170^{* *} \\
(2.56)\end{array}$ & & \\
\hline$\%$ Young Trustees $($ Age $<40)$ & & & & & $\begin{array}{l}0.062^{*} \\
(1.79)\end{array}$ & $\begin{array}{l}-0.001 \\
(-0.01)\end{array}$ \\
\hline Age Repr. Gap×\%Young Trus. $(<40)$ & & & & & & $\begin{array}{c}0.215^{* *} \\
(2.29)\end{array}$ \\
\hline Board Size & & $\begin{array}{l}0.319 \\
(1.06)\end{array}$ & $\begin{array}{l}0.317 \\
(1.05)\end{array}$ & $\begin{array}{c}0.318 \\
(1.08)\end{array}$ & $\begin{array}{l}0.327 \\
(1.08)\end{array}$ & $\begin{array}{l}0.323 \\
(1.10)\end{array}$ \\
\hline Board Average Tenure & & $\begin{array}{l}0.190 \\
(0.97)\end{array}$ & $\begin{array}{l}0.160 \\
(0.80)\end{array}$ & $\begin{array}{l}0.165 \\
(0.86)\end{array}$ & $\begin{array}{l}0.149 \\
(0.75)\end{array}$ & $\begin{array}{l}0.168 \\
(0.88)\end{array}$ \\
\hline$\%$ Female Trustees & & $\begin{array}{l}-0.050 \\
(-1.22)\end{array}$ & $\begin{array}{l}-0.046 \\
(-1.13)\end{array}$ & $\begin{array}{l}-0.042 \\
(-1.06)\end{array}$ & $\begin{array}{l}-0.042 \\
(-1.04)\end{array}$ & $\begin{array}{l}-0.043 \\
(-1.09)\end{array}$ \\
\hline \% Employer Trustees & & $\begin{array}{c}0.106^{* *} \\
(2.09)\end{array}$ & $\begin{array}{c}0.117^{* *} \\
(2.31)\end{array}$ & $\begin{array}{c}0.103^{* *} \\
(2.06)\end{array}$ & $\begin{array}{c}0.116^{* *} \\
(2.26)\end{array}$ & $\begin{array}{c}0.101^{* *} \\
(2.03)\end{array}$ \\
\hline$\%$ Retirees Trustees & & $\begin{array}{l}0.026 \\
(0.54)\end{array}$ & $\begin{array}{l}0.010 \\
(0.19)\end{array}$ & $\begin{array}{c}0.020 \\
(0.41)\end{array}$ & $\begin{array}{l}0.008 \\
(0.15)\end{array}$ & $\begin{array}{l}0.024 \\
(0.49)\end{array}$ \\
\hline$\%$ Independent Trustees & & $\begin{array}{l}0.038 \\
(0.68)\end{array}$ & $\begin{array}{l}0.040 \\
(0.70)\end{array}$ & $\begin{array}{l}0.034 \\
(0.58)\end{array}$ & $\begin{array}{l}0.040 \\
(0.68)\end{array}$ & $\begin{array}{l}0.037 \\
(0.62)\end{array}$ \\
\hline$\%$ University Degree & & $\begin{array}{l}0.026 \\
(0.81)\end{array}$ & $\begin{array}{l}0.025 \\
(0.77)\end{array}$ & $\begin{array}{c}0.032 \\
(0.99)\end{array}$ & $\begin{array}{l}0.027 \\
(0.84)\end{array}$ & $\begin{array}{l}0.030 \\
(0.93)\end{array}$ \\
\hline$\%$ Public Background & & $\begin{array}{l}0.064 \\
(0.63)\end{array}$ & $\begin{array}{l}0.052 \\
(0.51)\end{array}$ & $\begin{array}{l}0.042 \\
(0.43)\end{array}$ & $\begin{array}{l}0.048 \\
(0.46)\end{array}$ & $\begin{array}{l}0.048 \\
(0.47)\end{array}$ \\
\hline$\%$ Finance Background & & $\begin{array}{c}-0.104^{* * *} \\
(-2.73)\end{array}$ & $\begin{array}{c}-0.096^{* *} \\
(-2.50)\end{array}$ & $\begin{array}{c}-0.106^{* * *} \\
(-2.78)\end{array}$ & $\begin{array}{c}-0.092^{* *} \\
(-2.40)\end{array}$ & $\begin{array}{c}-0.104^{* * *} \\
(-2.73)\end{array}$ \\
\hline Average Age Active Participants & $\begin{array}{c}-0.465^{* * *} \\
(-2.77)\end{array}$ & $\begin{array}{c}-0.444^{* * *} \\
(-2.74)\end{array}$ & $\begin{array}{c}-0.454^{* * *} \\
(-2.81)\end{array}$ & $\begin{array}{c}-0.623^{* * *} \\
(-3.93)\end{array}$ & $\begin{array}{c}-0.449^{* * *} \\
(-2.78)\end{array}$ & $\begin{array}{c}-0.630^{* * *} \\
(-3.94)\end{array}$ \\
\hline$\%$ Retirees & $\begin{array}{l}0.039 \\
(0.84)\end{array}$ & $\begin{array}{l}0.023 \\
(0.52)\end{array}$ & $\begin{array}{l}0.012 \\
(0.29)\end{array}$ & $\begin{array}{l}0.020 \\
(0.49)\end{array}$ & $\begin{array}{l}0.010 \\
(0.22)\end{array}$ & $\begin{array}{l}0.014 \\
(0.35)\end{array}$ \\
\hline Log Size & $\begin{array}{c}0.803^{* *} \\
(2.09)\end{array}$ & $\begin{array}{l}0.782^{*} \\
(1.68)\end{array}$ & $\begin{array}{l}0.756 \\
(1.62)\end{array}$ & $\begin{array}{c}0.641 \\
(1.40)\end{array}$ & $\begin{array}{l}0.707 \\
(1.48)\end{array}$ & $\begin{array}{l}0.683 \\
(1.46)\end{array}$ \\
\hline Lag Funding Ratio & $\begin{array}{c}0.068^{* * *} \\
(3.28)\end{array}$ & $\begin{array}{c}0.074^{* * *} \\
(3.67)\end{array}$ & $\begin{array}{c}0.072^{* * *} \\
(3.57)\end{array}$ & $\begin{array}{c}0.070^{* * * *} \\
(3.71)\end{array}$ & $\begin{array}{c}0.073^{* * *} \\
(3.70)\end{array}$ & $\begin{array}{c}0.069^{* * *} \\
(3.73)\end{array}$ \\
\hline Swap Ratio & $\begin{array}{c}0.028 \\
(1.05)\end{array}$ & $\begin{array}{l}0.025 \\
(0.96)\end{array}$ & $\begin{array}{l}0.025 \\
(0.94)\end{array}$ & $\begin{array}{c}0.026 \\
(0.99)\end{array}$ & $\begin{array}{l}0.026 \\
(1.00)\end{array}$ & $\begin{array}{l}0.025 \\
(0.99)\end{array}$ \\
\hline Constant & $\begin{array}{c}35.281^{* * *} \\
(4.05) \\
\end{array}$ & $\begin{array}{c}42.199^{* * *} \\
(4.40) \\
\end{array}$ & $\begin{array}{c}26.489^{* * *} \\
(2.95) \\
\end{array}$ & $\begin{array}{c}37.871^{* * *} \\
(4.16) \\
\end{array}$ & $\begin{array}{c}27.304^{* * *} \\
(2.97) \\
\end{array}$ & $\begin{array}{c}37.871^{* * *} \\
(4.00) \\
\end{array}$ \\
\hline Time Dummies & Yes & Yes & Yes & Yes & Yes & Yes \\
\hline $\begin{array}{l}\text { Observations } \\
R^{2}\end{array}$ & $\begin{array}{l}1816 \\
0.077\end{array}$ & $\begin{array}{l}1761 \\
0.118\end{array}$ & $\begin{array}{l}1761 \\
0.108\end{array}$ & $\begin{array}{l}1761 \\
0.126\end{array}$ & $\begin{array}{l}1761 \\
0.106\end{array}$ & $\begin{array}{l}1761 \\
0.125\end{array}$ \\
\hline
\end{tabular}

Notes: The table shows a pooled OLS in Equation 2.1: $y_{i, t}=\alpha+X_{i, t} \beta+Z_{i, t} \gamma+\theta_{t}+\epsilon_{i, t}$. The dependent variable $y_{i, t}$ is the portfolio share of equity for pension fund $i$ in year $t . X_{i, t}$ is the set of pension fund characteristics, $Z_{i, t}$ is the set of board characteristics, and $\theta_{t}$ is the year fixed effect. We add a control variable to columns (4) and (6), namely the age-representation gap. The age-representation gap is a dummy variable that equals one when pension funds display a difference of 10 years or more between the average age of the active participants and the average age of the board. This dummy is then interacted with the share of young trustees on the board to capture their behavior in funds with a large age-representation gap. The table displays the results when limiting the sample to corporate pension funds only. The estimation relies on standard errors clustered at the pension fund level to correct for serial correlation. $t$ statistics in parentheses. ${ }^{*} p<0.1,{ }^{* *} p<0.05,{ }^{* * *} p<0.01$. 
Table 2.5: Board characteristics and equity allocation in non-corporate pension funds

\begin{tabular}{|c|c|c|c|c|c|c|}
\hline & $(1)$ & $(2)$ & $(3)$ & $(4)$ & (5) & $(6)$ \\
\hline Board Average Age & & $\begin{array}{l}-0.094 \\
(-0.49)\end{array}$ & & & & \\
\hline \% Young Trustees $($ Age $<46$ ) & & & $\begin{array}{c}0.052 \\
(0.86)\end{array}$ & $\begin{array}{l}0.071 \\
(0.97)\end{array}$ & & \\
\hline Age Representation Gap & & & & $\begin{array}{l}0.026 \\
(0.01)\end{array}$ & & $\begin{array}{l}-0.857 \\
(-0.43)\end{array}$ \\
\hline Age Repr. Gap×\%Young Trus. $(<46)$ & & & & $\begin{array}{l}-0.069 \\
(-0.67)\end{array}$ & & \\
\hline \% Young Trustees $($ Age $<40$ ) & & & & & $\begin{array}{l}0.067 \\
(0.73)\end{array}$ & $\begin{array}{l}0.074 \\
(0.64)\end{array}$ \\
\hline Age Repr. Gap×\%Young Trus. $(<40)$ & & & & & & $\begin{array}{l}-0.061 \\
(-0.39)\end{array}$ \\
\hline Board Size & & $\begin{array}{l}0.211 \\
(0.65)\end{array}$ & $\begin{array}{l}0.212 \\
(0.66)\end{array}$ & $\begin{array}{l}0.204 \\
(0.63)\end{array}$ & $\begin{array}{l}0.225 \\
(0.70)\end{array}$ & $\begin{array}{l}0.206 \\
(0.64)\end{array}$ \\
\hline Board Average Tenure & & $\begin{array}{l}0.303 \\
(1.13)\end{array}$ & $\begin{array}{l}0.289 \\
(1.07)\end{array}$ & $\begin{array}{l}0.294 \\
(1.09)\end{array}$ & $\begin{array}{r}0.283 \\
(1.04)\end{array}$ & $\begin{array}{l}0.298 \\
(1.11)\end{array}$ \\
\hline$\%$ Female Trustees & & $\begin{array}{l}-0.063 \\
(-1.61)\end{array}$ & $\begin{array}{l}-0.059 \\
(-1.52)\end{array}$ & $\begin{array}{l}-0.060 \\
(-1.54)\end{array}$ & $\begin{array}{l}-0.058 \\
(-1.53)\end{array}$ & $\begin{array}{l}-0.061 \\
(-1.57)\end{array}$ \\
\hline \% Employer Trustees & & $\begin{array}{l}-0.027 \\
(-0.49)\end{array}$ & $\begin{array}{l}-0.028 \\
(-0.51)\end{array}$ & $\begin{array}{l}-0.036 \\
(-0.72)\end{array}$ & $\begin{array}{l}-0.027 \\
(-0.49)\end{array}$ & $\begin{array}{l}-0.032 \\
(-0.63)\end{array}$ \\
\hline$\%$ Retirees Trustees & & $\begin{array}{l}0.056 \\
(1.08)\end{array}$ & $\begin{array}{l}0.057 \\
(1.14)\end{array}$ & $\begin{array}{l}0.051 \\
(1.00)\end{array}$ & $\begin{array}{c}0.063 \\
(1.23)\end{array}$ & $\begin{array}{l}0.055 \\
(1.03)\end{array}$ \\
\hline$\%$ Independent Trustees & & $\begin{array}{l}-0.001 \\
(-0.02)\end{array}$ & $\begin{array}{l}-0.001 \\
(-0.04)\end{array}$ & $\begin{array}{l}-0.003 \\
(-0.08)\end{array}$ & $\begin{array}{l}0.000 \\
(0.00)\end{array}$ & $\begin{array}{l}-0.001 \\
(-0.04)\end{array}$ \\
\hline \% University Degree & & $\begin{array}{l}0.002 \\
(0.05)\end{array}$ & $\begin{array}{l}0.003 \\
(0.07)\end{array}$ & $\begin{array}{l}0.001 \\
(0.02)\end{array}$ & $\begin{array}{l}0.003 \\
(0.08)\end{array}$ & $\begin{array}{l}-0.000 \\
(-0.01)\end{array}$ \\
\hline \% Public Background & & $\begin{array}{l}-0.011 \\
(-0.26)\end{array}$ & $\begin{array}{l}-0.013 \\
(-0.30)\end{array}$ & $\begin{array}{l}-0.011 \\
(-0.26)\end{array}$ & $\begin{array}{l}-0.012 \\
(-0.27)\end{array}$ & $\begin{array}{l}-0.011 \\
(-0.26)\end{array}$ \\
\hline$\%$ Finance Background & & $\begin{array}{l}-0.000 \\
(-0.01)\end{array}$ & $\begin{array}{l}-0.003 \\
(-0.06)\end{array}$ & $\begin{array}{l}0.002 \\
(0.05)\end{array}$ & $\begin{array}{l}-0.000 \\
(-0.00)\end{array}$ & $\begin{array}{l}0.006 \\
(0.11)\end{array}$ \\
\hline Average Age Active Participants & $\begin{array}{l}-0.083 \\
(-0.33)\end{array}$ & $\begin{array}{l}-0.067 \\
(-0.27)\end{array}$ & $\begin{array}{l}-0.047 \\
(-0.19)\end{array}$ & $\begin{array}{l}-0.090 \\
(-0.36)\end{array}$ & $\begin{array}{l}-0.066 \\
(-0.26)\end{array}$ & $\begin{array}{l}-0.110 \\
(-0.43)\end{array}$ \\
\hline$\%$ Retirees & $\begin{array}{l}-0.008 \\
(-0.07)\end{array}$ & $\begin{array}{l}-0.031 \\
(-0.27)\end{array}$ & $\begin{array}{l}-0.036 \\
(-0.32)\end{array}$ & $\begin{array}{l}-0.043 \\
(-0.38)\end{array}$ & $\begin{array}{l}-0.031 \\
(-0.28)\end{array}$ & $\begin{array}{l}-0.040 \\
(-0.35)\end{array}$ \\
\hline Log Size & $\begin{array}{l}0.600 \\
(1.50)\end{array}$ & $\begin{array}{l}0.485 \\
(0.86)\end{array}$ & $\begin{array}{l}0.511 \\
(0.90)\end{array}$ & $\begin{array}{l}0.518 \\
(0.90)\end{array}$ & $\begin{array}{l}0.465 \\
(0.83)\end{array}$ & $\begin{array}{l}0.511 \\
(0.91)\end{array}$ \\
\hline Lag Funding Ratio & $\begin{array}{l}0.013 \\
(0.32)\end{array}$ & $\begin{array}{l}0.009 \\
(0.21)\end{array}$ & $\begin{array}{l}0.006 \\
(0.14)\end{array}$ & $\begin{array}{l}0.008 \\
(0.19)\end{array}$ & $\begin{array}{l}0.007 \\
(0.16)\end{array}$ & $\begin{array}{l}0.009 \\
(0.22)\end{array}$ \\
\hline Swap Ratio & $\begin{array}{l}0.045 \\
(1.28)\end{array}$ & $\begin{array}{l}0.037 \\
(1.05)\end{array}$ & $\begin{array}{l}0.036 \\
(1.02)\end{array}$ & $\begin{array}{l}0.034 \\
(0.93)\end{array}$ & $\begin{array}{c}0.036 \\
(1.04)\end{array}$ & $\begin{array}{l}0.035 \\
(0.94)\end{array}$ \\
\hline Constant & $\begin{array}{c}27.896^{* *} \\
(2.21) \\
\end{array}$ & $\begin{array}{c}33.029^{* *} \\
(2.29) \\
\end{array}$ & $\begin{array}{c}26.807^{*} \\
(1.97) \\
\end{array}$ & $\begin{array}{c}28.872^{* *} \\
(2.12) \\
\end{array}$ & $\begin{array}{c}28.199^{* *} \\
(2.11) \\
\end{array}$ & $\begin{array}{c}30.183^{* *} \\
(2.23) \\
\end{array}$ \\
\hline Time Dummies & Yes & Yes & Yes & Yes & Yes & Yes \\
\hline Observations & 640 & 631 & 631 & 631 & 631 & 631 \\
\hline$R^{2}$ & 0.067 & 0.087 & 0.090 & 0.094 & 0.089 & 0.092 \\
\hline
\end{tabular}

Notes: The table shows a pooled OLS in Equation 2.1: $y_{i, t}=\alpha+X_{i, t} \beta+Z_{i, t} \gamma+\theta_{t}+\epsilon_{i, t}$. The dependent variable $y_{i, t}$ is the portfolio share of equity for pension fund $i$ in year $t$. $X_{i, t}$ is the set of pension fund characteristics, $Z_{i, t}$ is the set of board characteristics, and $\theta_{t}$ is the year fixed effect. We add a control variable to columns (4) and (6), namely the age-representation gap. The age-representation gap is a dummy variable that equals one when pension funds display a difference of 10 years or more between the average age of the active participants and the average age of the board. This dummy is then interacted with the share of young trustees on the board to capture their behavior in funds with a large age-representation gap. The table displays the results when limiting the sample to non-corporate pension funds only. The estimation relies on standard errors clustered at the pension fund level to correct for serial correlation. $t$ statistics in parentheses. ${ }^{*} p<0.1,{ }^{* *} p<0.05,{ }^{* * *} p<0.01$. 
there is a direct incentive for them to pursue their own optimal life-cycle investment strategy. In our data, we identify trustees who are also the plan's beneficiaries in the following way. In corporate pension funds, both the trustees of the beneficiaries and of the employer are employees of the same company, and therefore also the plan's beneficiaries. In industry-wide pension funds, by contrast, there can be a large group of corporations that sponsor the plan, in some cases tens of thousands of small companies. Therefore, trustees are typically selected from the labor union that is active in the specific industry or are professionals not employed by any of the sponsors. It follows that trustees in industry-wide pension funds are for the most part not beneficiaries of the pension funds to which they are appointed.

In Table 2.4 and Table 2.5, we test the effect of board characteristics on the strategic equity allocation of corporate pension funds and non-corporate pension funds separately ${ }^{21}$ We find evidence of a trustee-age effect in corporate pension funds, but no evidence of this effect in non-corporate pension funds. Trustees who are also beneficiaries of the plan consider their own age while designing the SAAs of pension funds. Conversely, trustees that are not beneficiaries of the plan do not exhibit the same behavior. The average age of trustees is associated with lower equity allocations in corporate pension funds, while it is not in non-corporate pension funds (see Columns (2), (3), and (5) in Table 2.4 and Table 2.5). The effect of the age-representation gap is strong in corporate pension funds, while it is nonexistent in industry-wide and professional group pension funds (Columns (4) and (6)). Moreover, young trustees in the presence of a large age-representation gap promote a riskier allocation in corporate pension funds, while this behavior is not observed in noncorporate pension funds (Columns (4) and (6)). The latter effect is both statistically and economically significant. Take two corporate pension funds with an average board of seven trustees ${ }^{22}$ Both pension funds display a large age-representation gap.

\footnotetext{
${ }^{21}$ We analyze professional group pension funds together with industry-wide pension funds because their trustees are often union members as well. In addition, there is no clear separation between employer and employees for the professional groups and therefore there are no diverging interests between the two groups. Professional pension funds represent only 4 percent of the institutions in our sample, and excluding them from the analysis does not change the results.

${ }^{22}$ Table 2.11 and Table 2.12 in the Internet Appendix provide the summary statistics of corporate and non-corporate pension funds. There are some differences in the average age of beneficiaries and
} 
Pension fund $A$ has no young trustees, while pension fund $B$ has one trustee younger than 40 years old. On average, pension fund $B$ will allocate $3(=(-0.001+0.215) * 14)$ percentage points more to equity than pension fund $A$, ceteris paribus. Conversely, no difference is detected between $A$ and $B$ if both are non-corporate pension funds.

The economic effect of the difference between the average board age and the average participant age on the strategic equity allocation is sizeable. Figure 2-5 displays the equity allocation predicted by the baseline model and by the model with board characteristics for the average corporate pension fund (based on Columns (1) and (2) of Table 2.4. All variables are kept at their sample mean, except for the average age of active participants. The figure shows that including board characteristics in the model lowers the predicted equity allocation by 7 percentage points for any average age of active participants. Therefore, the effect of board characteristics on SAAs is sizable and moves the allocation to equity away from the value predicted by the pension fund characteristics. We attribute this result to the fact that trustees are generally older than the average participant. Considering an average equity return of 6 percent per year and a contribution period of 40 years, the participants of a corporate pension fund with a 7 percentage points lower allocation than the average pension fund will have a 9 percent lower terminal wealth ${ }^{23}$

The results from this section indicate that in corporate pension funds, trustees design the SAAs in such a way that they are more in line with their life-cycle investment objectives. The fact that we do not observe similar results for pension funds in which trustees are not necessarily beneficiaries themselves indicates that the incentive of being a beneficiary encourages trustees to value their own characteristics when they design the SAAs. Nevertheless, we cannot exclude that some trustees might unknowingly project their own preferences (Dohmen et al. (2017); Falk et al. (2018)) onto

in the age of board members. However, these differences are not very large.

${ }^{23}$ We compute terminal wealth $X$ as follows:

$$
X=\frac{(1+w R)^{T+1}-(1+w R)}{w R}
$$

where $w$ is the strategic equity allocation, $R$ is the expected equity return, and $T$ is the contribution period. We assume that the return on bonds is negligible. 


\section{Figure 2-5. Predicted equity allocation of corporate pension fund}

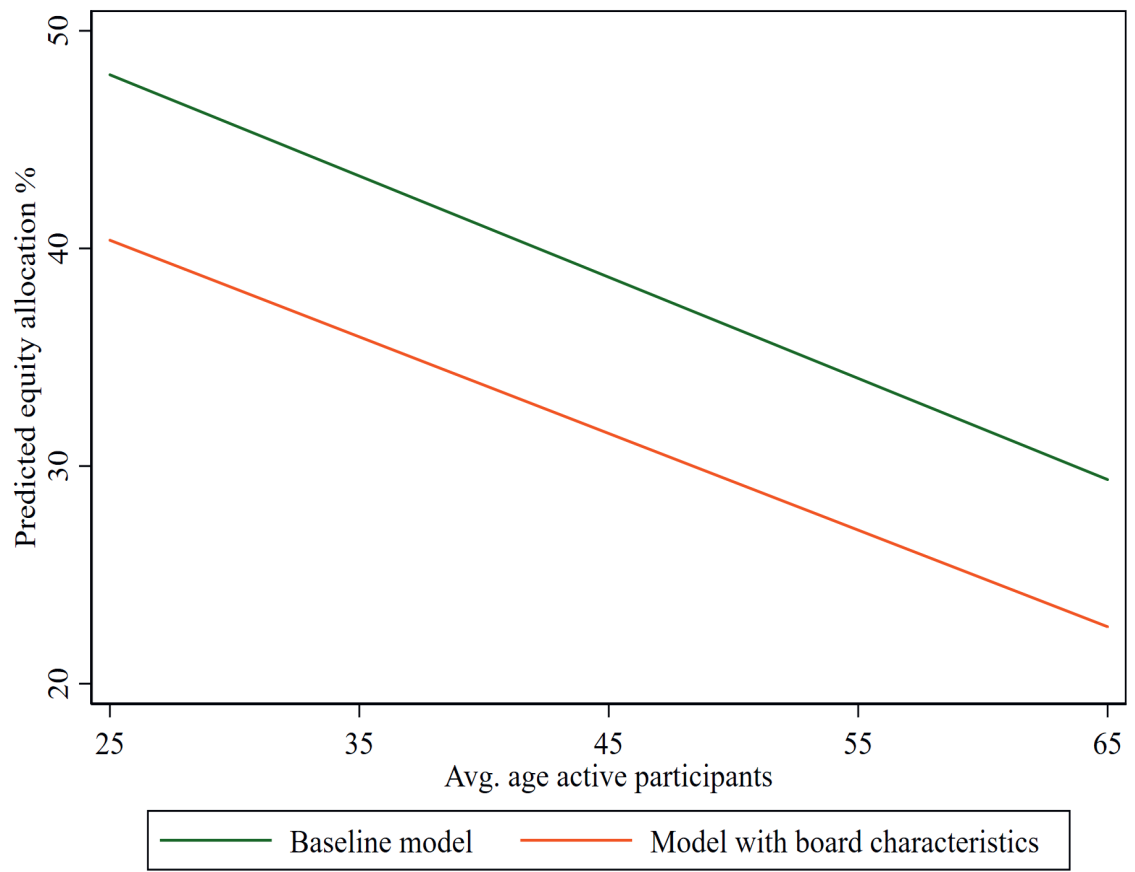

Notes: The figure shows the equity allocation of the average pension fund predicted by the baseline model in column (1) in Table 2.4 and by the model augmented with board characteristics in column (2).

beneficiaries and as a result make biased decisions. This type of decision is known as the interpersonal empathy-gap in the social-psychology literature (Loewenstein (2005)). Despite the underlying motivation, by valuing their own preferences trustees design SAAs that do not reflect the average characteristics of all beneficiaries.

Column (1) of Table 2.5 shows that the strategic equity allocation is not correlated to any of the characteristics of non-corporate pension funds. This striking result could be the consequence of a lack of power due to the reduced number of observations: the clustered standard error reduces the significance of all variables. For example, the magnitude of the coefficient associated with the non-corporate pension funds' log size is similar to the magnitude of the coefficient for the corporate pension funds' log size, although the former is not significant. Moreover, a univariate regression of the equity allocation of industry wide pension funds on the average age of active participants 
shows a significant coefficient of $-0.174(\mathrm{t}$-stat $=2.09){ }^{24}$

\subsection{Stakeholder representation and strategic equity allocation}

Next, we turn to the effect of stakeholder representation on the strategic equity allocation. In Table 2.2 and in Table 2.3 we did not find evidence of a representation effect in the full sample of pension funds. Neither the fraction of employer trustees nor the fraction of retiree trustees affects the strategic equity allocation. In contrast to these findings, Table 2.4 indicates the presence of a representation effect in corporate pension funds. The fraction of employer trustees is positively correlated with the strategic equity allocation. Corporate pension funds with a higher fraction of employer trustees relative to participant trustees invest more in equity than corporate pension funds that have a lower fraction of employer trustees. One additional trustee that represents the employer means a 1.6 percentage point higher strategic equity allocation, if the trustee is gained at the expense of a participant trustee. There are two possible explanations for this imbalance of power. First, beneficiaries can have both participants' and retirees' trustees. The more retirees' trustees there are, the less powerful the trustees of the active participants are vis-a-vis the employer trustees. From Table 2.1 we indeed learn that there is such an imbalance: the fraction of trustees who represent the employer is 46 percent, while the fraction of trustees who represent active participants is only 38 percent. Second, trustees that leave a board or whose term ends create vacancies. It might be the case that pension funds can more easily fill the vacancies for employer trustees because these persons are selected rather than appointed via a lengthy election process.

The question is why employer trustees would safeguard the interests of their constituencies by pushing for riskier asset allocations. Our answer is that higher strategic equity exposure will increase the value of the claim that the employer has on the assets in case of overfunding. In the event of substantial overfunding, employers can

\footnotetext{
${ }^{24}$ See Figure ?? in the Internet Appendix.
} 
reduce contributions or even withdraw assets from their pension funds ${ }^{25}$ Conversely, in the event of severe underfunding, the employers have a claim against the beneficiaries, because in such a case a pension fund is required by law to reduce the accrued pension benefits ${ }^{26}$ This reduction can be seen as an implicit put option on the pension fund's assets (Treynor (1977)). By safeguarding their constituencies' interests, employer trustees can in turn receive career benefits (Cocco and Volpin (2007)) or justify their appointments (Goyal and Wahal (2008)).

Employer trustees may be motivated to act in this way to support their personal career. They may logically think that if they do good by the employer, the employer will do good by them. If trustees consider their own career when they design the SAAs, they create a principal-agent problem. A principal-agent problem in pension funds exists because the interests of the plan's beneficiaries are not fully aligned with the interests of the trustees (Lakonishok et al. (1992a)). Through their trustees, an employer can exercise influence on the investment decisions of the pension fund. Furthermore, in corporate pension funds (public) scrutiny is low due to their small size and the low number of social partners involved. By contrast, because trustees are less likely to be employees of a sponsor in an industry-wide pension fund, the incentives to consider their own career concerns are also lower. Furthermore, as trustees of industry-wide pension funds are generally union representatives, their decisions might be coordinated at the union level. These pension funds are on average larger than corporate pension funds and involve a greater number of social partners such as the employers' federation and the employees and retirees' union. As a result, industry-wide pension funds face greater scrutiny that discourages trustees from valuing individual characteristics when they make investment decisions.

\footnotetext{
${ }^{25}$ Article 129 of the Dutch Pension Act describes under what conditions assets can go back from the pension fund to the employer.

${ }^{26}$ Article 134 of the Dutch Pension Act describes under what conditions pension funds are required to reduce accrued benefits to restore full funding.
} 


\subsection{Board characteristics, alternative allocations, and returns}

Corporate pension funds with young trustees or with more employer trustees allocate more to equity. Next to a higher equity allocation, there are two other ways in which pension funds can pursue a riskier investment strategy. First, pension funds can increase their allocation to alternative asset classes that are riskier than equity. Second, they can opt for an active equity mandate. This decision to "go active" has a potential effect on the performance of the equity portfolio. In this section, we test whether board characteristics are related to the allocation to alternative asset classes in the same way they are related to the strategic equity allocation. Then, we explore the relation between board characteristics and pension fund benchmarkadjusted performance as a proxy for active equity mandates.

\subsubsection{Board characteristics and alternative allocations}

We estimate the model in Equation (2.1) to test the correlation between board characteristics and the strategic allocations to private equity, hedge funds, real estate, and commodities pooled together. Table 2.6 shows the results. We find no relation between the allocation to alternatives and age-related board characteristics. However, we do find that board size has an important effect on the strategic allocation to alternatives. Large boards allocate more to alternative asset classes. This allocation shows that large boards are driven to more complex and sophisticated asset classes. Furthermore, large boards have more capacity to invest in asset classes that involve more management time ${ }^{27}$ However, the fraction of board members with a financial background strikingly does not have an effect on the allocation to alternatives. This is remarkable because alternatives are more sophisticated investments. Therefore, modifying the allocation to these asset classes requires a more careful assessment from

\footnotetext{
${ }^{27}$ The correlation between the board size and the log assets of pension funds is positive but not very high (0.58). We test for multicollinearity by regressing the alternative allocation on the board size and log assets separately and then together, and no major change in the level and direction of the coefficients were recorded.
} 
Table 2.6: Board characteristics and strategic alternative allocation

\begin{tabular}{|c|c|c|c|c|c|c|}
\hline & $(1)$ & $(2)$ & $(3)$ & $(4)$ & $(5)$ & (6) \\
\hline Board Average Age & $\begin{array}{l}0.082 \\
(1.37)\end{array}$ & & & & & \\
\hline Board Median Age & & $\begin{array}{l}0.044 \\
(0.86)\end{array}$ & & & & \\
\hline \% Young Trustees $($ Age $<46$ ) & & & $\begin{array}{l}-0.020 \\
(-1.28)\end{array}$ & $\begin{array}{l}-0.004 \\
(-0.24)\end{array}$ & & \\
\hline Age Representation Gap & & & & $\begin{array}{l}1.203^{*} \\
(1.65)\end{array}$ & & $\begin{array}{c}1.306^{* *} \\
(2.04)\end{array}$ \\
\hline Age Repr. Gap×\%Young Trus. $(<46)$ & & & & $\begin{array}{l}-0.033 \\
(-0.95)\end{array}$ & & \\
\hline$\%$ Young Trustees $($ Age $<40$ ) & & & & & $\begin{array}{l}-0.020 \\
(-0.90)\end{array}$ & $\begin{array}{l}0.004 \\
(0.17)\end{array}$ \\
\hline Age Repr. Gap×\%Young Trus. $(<40)$ & & & & & & $\begin{array}{l}-0.077 \\
(-1.44)\end{array}$ \\
\hline Board Size & $\begin{array}{c}0.461^{* * *} \\
(2.73)\end{array}$ & $\begin{array}{c}0.460^{* * *} \\
(2.72)\end{array}$ & $\begin{array}{c}0.460^{* * *} \\
(2.73)\end{array}$ & $\begin{array}{c}0.463^{* * *} \\
(2.75)\end{array}$ & $\begin{array}{c}0.456^{* * *} \\
(2.71)\end{array}$ & $\begin{array}{c}0.456^{* * *} \\
(2.72)\end{array}$ \\
\hline Board Average Tenure & $\begin{array}{l}0.198 \\
(1.54)\end{array}$ & $\begin{array}{l}0.209 \\
(1.61)\end{array}$ & $\begin{array}{l}0.203 \\
(1.57)\end{array}$ & $\begin{array}{l}0.200 \\
(1.54)\end{array}$ & $\begin{array}{l}0.208 \\
(1.59)\end{array}$ & $\begin{array}{l}0.205 \\
(1.59)\end{array}$ \\
\hline$\%$ Female Trustees & $\begin{array}{l}0.026 \\
(1.19)\end{array}$ & $\begin{array}{l}0.024 \\
(1.13)\end{array}$ & $\begin{array}{l}0.025 \\
(1.14)\end{array}$ & $\begin{array}{l}0.025 \\
(1.14)\end{array}$ & $\begin{array}{l}0.024 \\
(1.09)\end{array}$ & $\begin{array}{l}0.024 \\
(1.09)\end{array}$ \\
\hline \% Employer Trustees & $\begin{array}{l}-0.038 \\
(-1.40)\end{array}$ & $\begin{array}{l}-0.039 \\
(-1.40)\end{array}$ & $\begin{array}{l}-0.041 \\
(-1.49)\end{array}$ & $\begin{array}{l}-0.039 \\
(-1.44)\end{array}$ & $\begin{array}{l}-0.041 \\
(-1.49)\end{array}$ & $\begin{array}{l}-0.038 \\
(-1.43)\end{array}$ \\
\hline \% Retirees Trustees & $\begin{array}{l}0.016 \\
(0.56)\end{array}$ & $\begin{array}{l}0.019 \\
(0.66)\end{array}$ & $\begin{array}{l}0.018 \\
(0.62)\end{array}$ & $\begin{array}{l}0.016 \\
(0.54)\end{array}$ & $\begin{array}{l}0.019 \\
(0.64)\end{array}$ & $\begin{array}{l}0.015 \\
(0.50)\end{array}$ \\
\hline$\%$ Independent Trustees & $\begin{array}{l}0.027 \\
(0.99)\end{array}$ & $\begin{array}{l}0.026 \\
(0.98)\end{array}$ & $\begin{array}{l}0.026 \\
(0.96)\end{array}$ & $\begin{array}{l}0.025 \\
(0.95)\end{array}$ & $\begin{array}{l}0.026 \\
(0.94)\end{array}$ & $\begin{array}{l}0.025 \\
(0.91)\end{array}$ \\
\hline \% University Degree & $\begin{array}{l}-0.017 \\
(-0.98)\end{array}$ & $\begin{array}{l}-0.017 \\
(-0.98)\end{array}$ & $\begin{array}{l}-0.017 \\
(-0.97)\end{array}$ & $\begin{array}{l}-0.018 \\
(-1.00)\end{array}$ & $\begin{array}{l}-0.018 \\
(-1.00)\end{array}$ & $\begin{array}{l}-0.017 \\
(-1.00)\end{array}$ \\
\hline \% Public Background & $\begin{array}{l}0.028 \\
(1.01)\end{array}$ & $\begin{array}{l}0.029 \\
(1.02)\end{array}$ & $\begin{array}{l}0.029 \\
(1.02)\end{array}$ & $\begin{array}{l}0.030 \\
(1.08)\end{array}$ & $\begin{array}{l}0.029 \\
(1.05)\end{array}$ & $\begin{array}{l}0.031 \\
(1.10)\end{array}$ \\
\hline$\%$ Finance Background & $\begin{array}{l}0.001 \\
(0.05)\end{array}$ & $\begin{array}{l}-0.000 \\
(-0.00)\end{array}$ & $\begin{array}{l}0.001 \\
(0.04)\end{array}$ & $\begin{array}{l}0.002 \\
(0.08)\end{array}$ & $\begin{array}{l}-0.001 \\
(-0.04)\end{array}$ & $\begin{array}{l}0.001 \\
(0.04)\end{array}$ \\
\hline Average Age Active Participants & $\begin{array}{c}-0.230^{* * *} \\
(-2.92)\end{array}$ & $\begin{array}{c}-0.225^{* * *} \\
(-2.86)\end{array}$ & $\begin{array}{c}-0.230^{* * *} \\
(-2.91)\end{array}$ & $\begin{array}{c}-0.189^{* *} \\
(-2.42)\end{array}$ & $\begin{array}{c}-0.228^{* * *} \\
(-2.94)\end{array}$ & $\begin{array}{c}-0.183^{* *} \\
(-2.44)\end{array}$ \\
\hline$\%$ Retirees & $\begin{array}{l}0.047^{*} \\
(1.76)\end{array}$ & $\begin{array}{l}0.048^{*} \\
(1.79)\end{array}$ & $\begin{array}{l}0.050^{*} \\
(1.88)\end{array}$ & $\begin{array}{l}0.049^{*} \\
(1.88)\end{array}$ & $\begin{array}{l}0.050^{*} \\
(1.92)\end{array}$ & $\begin{array}{c}0.050^{* *} \\
(2.00)\end{array}$ \\
\hline Log Size & $\begin{array}{c}1.620^{* * *} \\
(7.04)\end{array}$ & $\begin{array}{c}1.641^{* * *} \\
(7.14)\end{array}$ & $\begin{array}{c}1.617^{* * *} \\
(7.03)\end{array}$ & $\begin{array}{c}1.626^{* * *} \\
(7.11)\end{array}$ & $\begin{array}{c}1.638^{* * *} \\
(7.09)\end{array}$ & $\begin{array}{c}1.636^{* * *} \\
(7.15)\end{array}$ \\
\hline Lag Funding Ratio & $\begin{array}{l}0.018 \\
(1.48)\end{array}$ & $\begin{array}{l}0.019 \\
(1.50)\end{array}$ & $\begin{array}{l}0.020 \\
(1.58)\end{array}$ & $\begin{array}{l}0.020 \\
(1.60)\end{array}$ & $\begin{array}{l}0.019 \\
(1.56)\end{array}$ & $\begin{array}{l}0.020^{*} \\
(1.76)\end{array}$ \\
\hline Swap Ratio & $\begin{array}{c}0.036^{* * *} \\
(2.83)\end{array}$ & $\begin{array}{c}0.035^{* * *} \\
(2.78)\end{array}$ & $\begin{array}{c}0.036^{* * *} \\
(2.81)\end{array}$ & $\begin{array}{c}0.037^{* * *} \\
(2.91)\end{array}$ & $\begin{array}{c}0.035^{* * *} \\
(2.77)\end{array}$ & $\begin{array}{c}0.037^{* * *} \\
(2.98)\end{array}$ \\
\hline Professional Pension Funds. & $\begin{array}{l}0.142 \\
(0.07)\end{array}$ & $\begin{array}{l}0.102 \\
(0.05)\end{array}$ & $\begin{array}{l}0.084 \\
(0.04)\end{array}$ & $\begin{array}{l}0.017 \\
(0.01)\end{array}$ & $\begin{array}{l}0.035 \\
(0.02)\end{array}$ & $\begin{array}{l}-0.022 \\
(-0.01)\end{array}$ \\
\hline Industry Pension Funds. & $\begin{array}{l}0.369 \\
(0.32)\end{array}$ & $\begin{array}{l}0.415 \\
(0.36)\end{array}$ & $\begin{array}{l}0.423 \\
(0.38)\end{array}$ & $\begin{array}{l}0.244 \\
(0.21)\end{array}$ & $\begin{array}{l}0.438 \\
(0.39)\end{array}$ & $\begin{array}{l}0.196 \\
(0.17)\end{array}$ \\
\hline Constant & $\begin{array}{c}-12.162^{* *} \\
(-2.17) \\
\end{array}$ & $\begin{array}{c}-10.871^{* *} \\
(-1.97) \\
\end{array}$ & $\begin{array}{l}-7.835 \\
(-1.54) \\
\end{array}$ & $\begin{array}{c}-10.313^{* *} \\
(-2.02) \\
\end{array}$ & $\begin{array}{r}-8.344^{*} \\
(-1.66) \\
\end{array}$ & $\begin{array}{c}-10.949^{* *} \\
(-2.18) \\
\end{array}$ \\
\hline Time Dummies & Yes & Yes & Yes & Yes & Yes & Yes \\
\hline Observations & 2392 & 2392 & 2392 & 2392 & 2392 & 2392 \\
\hline$R^{2}$ & 0.308 & 0.307 & 0.307 & 0.309 & 0.307 & 0.310 \\
\hline
\end{tabular}

Notes: The table shows a pooled OLS in Equation 2.1): $y_{i, t}=\alpha+X_{i, t} \beta+Z_{i, t} \gamma+\theta_{t}+\epsilon_{i, t}$. The dependent variable $y_{i, t}$ is the portfolio share of alternative asset classes for pension fund $i$ in year $t$. Alternatives are real estate, hedge funds, private equity, and commodities. $X_{i, t}$ are pension fund characteristics, $Z_{i, t}$ are board characteristics, and $\theta_{t}$ is the year fixed effect. We add a control variable to columns (4) and (6), namely the age-representation gap that is a dummy variable that equals one when pension funds display a difference of 10 years or more between the average age of the active participants and the average age of the board. This dummy is then interacted with the share of young trustees on the board. The estimation relies on standard errors clustered at the pension fund level to correct for serial correlation. $t$ statistics in parentheses. ${ }^{*} p<0.1,{ }^{* *} p<0.05,{ }^{* * *} p<0.01$. 
trustees and the sophistication of a pension should primarily drive these decisions.

\subsubsection{Board characteristics and equity performance}

Pension funds can also enter into a riskier investment strategy via an active equity mandate. The hypothesis is that young trustees can push pension funds to increase risk via active mandates, hence taking more risk relative to the risk of the benchmark in a particular asset class. The objective of an active mandate is to have higher benchmark-adjusted returns. Conversely, if young trustees favor passive mandates, this preference will not lead to a higher benchmark-adjusted return. Whether pension funds invest in active or passive mandates is not observable in the data. However, we can study the relation between the board characteristics and the absolute equity portfolio returns and the benchmark-adjusted returns. We are interested in studying if the changes in board characteristics that are driven by trustee turnover influence both measures of performance. If young trustees - who might favor higher withinasset class risk - are newly appointed to the board, this presence could correlate with higher (benchmark-adjusted) performance in the equity portfolio. Looking at newly appointed young trustees allows us to capture the effect of a decrease in the board age.

We rely on the following within-effect regression that facilitates the assessment of the correlation between board characteristics and the performance of each pension fund over time. This model also allows us to capture unobservable pension fundspecific characteristics that affect performance such as equity manager skills

$$
y_{i, t}=\alpha+X_{i, t} \beta+Z_{i, t} \gamma+\theta_{t}+\mu_{i}+\epsilon_{i, t}
$$

The dependent variable in Equation (2.3) is the total return, net of fees, for the equity portfolio of pension fund $i$ in year $t . X_{i, t}$ and $Z_{i, t}$ are pension fund and board characteristics, as in Equation (2.1). $\theta_{t}$ and $\mu_{i}$ indicate year and pension fund fixed effects. In this analysis, we are mainly interested in the time variation in the returns and the effect of the variation in some board characteristics such as hiring young 
trustees on the equity performance ${ }^{28}$ Thus, we include a variable that equals one when a young trustee is hired at the beginning of the year and zero otherwise. A trustee is classified as young if he or she is younger than 46 or 40 years old, as in the previous sections ${ }^{29}$

Table 2.7 present the results. Columns (1) and (2) show that board characteristics are not related with the absolute returns on the equity portfolio. Specifically, pension funds that hire young trustees do not report either higher or lower returns over time. Similarly, if the employer trustees share increases with respect to the share of participant trustees, the equity performance remains unaffected. The same holds for variations in the trustees' backgrounds. In Columns (3) and (4), we test the effect of board characteristics on benchmark-adjusted returns. The results indicate that the benchmark-adjusted returns are higher for pension funds with a higher fraction of trustees with a financial background. One additional trustee with a financial background corresponds to a 30 basis point higher benchmark-adjusted return on the equity portfolio of a pension fund with an average of seven members on the board. This return indicates that trustees' financial expertise and experience contribute to the design of more profitable equity allocations. Conversely, the hiring of a young trustee is not related to the benchmark-adjusted returns. Thus, trustee turnover can be beneficial to benchmark-adjusted performance, if it increases the financial expertise on the board. Logically, improving the financial expertise on the board might not necessarily require hiring young trustees (see, e.g., Clark (2004)) 30

In sum, we cannot directly observe if pension funds with more board members of a young age increase the equity allocation by investing more in active or passive mandates. However, we observe that the additions of young trustees to a board are not associated with significant differences in absolute or relative equity returns. However, adding more financial expertise to the board appears to be beneficial.

\footnotetext{
${ }^{28}$ The results are unchanged if we use the share of young trustees as in the previous sections.

${ }^{29}$ In Equation 2.11 we are interested in explaining the cross-sectional differences in the strategic equity allocations of pension funds with their board characteristics. Instead, in Equation 2.3 we are interested in explaining the evolution of the equity performance of each pension fund with the evolution of its board characteristics.

${ }^{30}$ The results are similar if we investigate the two or three-year performance instead of the one-year performance.
} 
Table 2.7: Board characteristics and the performance of the equity portfolio

\begin{tabular}{|c|c|c|c|c|}
\hline & \multicolumn{2}{|c|}{ Equity Year Return } & \multicolumn{2}{|c|}{ Bmk. Adj. Return } \\
\hline & $(1)$ & $(2)$ & $(3)$ & $(4)$ \\
\hline New Trustee (Age < 46) & $\begin{array}{l}0.592 \\
(1.41)\end{array}$ & & $\begin{array}{l}0.108 \\
(0.46)\end{array}$ & \\
\hline New Trustee (Age < 40) & & $\begin{array}{c}0.726 \\
(1.30)\end{array}$ & & $\begin{array}{l}-0.075 \\
(-0.25)\end{array}$ \\
\hline Board Size & $\begin{array}{l}-0.121 \\
(-1.23)\end{array}$ & $\begin{array}{l}-0.120 \\
(-1.21)\end{array}$ & $\begin{array}{l}-0.040 \\
(-0.69)\end{array}$ & $\begin{array}{l}-0.039 \\
(-0.67)\end{array}$ \\
\hline Board Average Tenure & $\begin{array}{l}0.107 \\
(1.29)\end{array}$ & $\begin{array}{l}0.105 \\
(1.26)\end{array}$ & $\begin{array}{l}0.024 \\
(0.56)\end{array}$ & $\begin{array}{c}0.020 \\
(0.46)\end{array}$ \\
\hline$\%$ Female Trustees & $\begin{array}{l}-0.015 \\
(-0.97)\end{array}$ & $\begin{array}{l}-0.015 \\
(-0.96)\end{array}$ & $\begin{array}{l}0.004 \\
(0.48)\end{array}$ & $\begin{array}{c}0.004 \\
(0.51)\end{array}$ \\
\hline \% Employer Trustees & $\begin{array}{l}-0.019 \\
(-0.98)\end{array}$ & $\begin{array}{l}-0.019 \\
(-0.97)\end{array}$ & $\begin{array}{l}-0.016 \\
(-1.39)\end{array}$ & $\begin{array}{l}-0.016 \\
(-1.36)\end{array}$ \\
\hline \% Retirees Trustees & $\begin{array}{l}-0.025 \\
(-1.33)\end{array}$ & $\begin{array}{l}-0.024 \\
(-1.28)\end{array}$ & $\begin{array}{l}-0.004 \\
(-0.38)\end{array}$ & $\begin{array}{l}-0.004 \\
(-0.38)\end{array}$ \\
\hline \% Independent Trustees & $\begin{array}{l}0.003 \\
(0.20)\end{array}$ & $\begin{array}{l}0.003 \\
(0.20)\end{array}$ & $\begin{array}{l}-0.003 \\
(-0.36)\end{array}$ & $\begin{array}{l}-0.003 \\
(-0.34)\end{array}$ \\
\hline \% University Degree & $\begin{array}{l}-0.010 \\
(-0.69)\end{array}$ & $\begin{array}{l}-0.010 \\
(-0.71)\end{array}$ & $\begin{array}{l}-0.006 \\
(-0.91)\end{array}$ & $\begin{array}{l}-0.006 \\
(-0.91)\end{array}$ \\
\hline \% Public Background & $\begin{array}{l}-0.006 \\
(-0.33)\end{array}$ & $\begin{array}{l}-0.005 \\
(-0.28)\end{array}$ & $\begin{array}{l}0.008 \\
(0.62)\end{array}$ & $\begin{array}{l}0.008 \\
(0.63)\end{array}$ \\
\hline$\%$ Finance Background & $\begin{array}{l}0.012 \\
(0.78)\end{array}$ & $\begin{array}{l}0.013 \\
(0.82)\end{array}$ & $\begin{array}{c}0.021^{* * *} \\
(2.64)\end{array}$ & $\begin{array}{c}0.021^{* * *} \\
(2.65)\end{array}$ \\
\hline Average Age Active Participants & $\begin{array}{l}-0.103 \\
(-0.74)\end{array}$ & $\begin{array}{l}-0.101 \\
(-0.73)\end{array}$ & $\begin{array}{l}0.022 \\
(0.52)\end{array}$ & $\begin{array}{c}0.023 \\
(0.54)\end{array}$ \\
\hline$\%$ Retirees & $\begin{array}{l}0.022 \\
(0.44)\end{array}$ & $\begin{array}{l}0.021 \\
(0.42)\end{array}$ & $\begin{array}{l}0.015 \\
(0.59)\end{array}$ & $\begin{array}{c}0.014 \\
(0.56)\end{array}$ \\
\hline Log Size & $\begin{array}{l}1.395^{*} \\
(1.82)\end{array}$ & $\begin{array}{l}1.416^{*} \\
(1.84)\end{array}$ & $\begin{array}{l}0.823^{*} \\
(1.70)\end{array}$ & $\begin{array}{l}0.822^{*} \\
(1.70)\end{array}$ \\
\hline Lag Funding Ratio & $\begin{array}{c}-0.044^{* *} \\
(-2.05)\end{array}$ & $\begin{array}{c}-0.044^{* *} \\
(-2.05)\end{array}$ & $\begin{array}{l}0.002 \\
(0.18)\end{array}$ & $\begin{array}{c}0.002 \\
(0.18)\end{array}$ \\
\hline Swap Ratio & $\begin{array}{l}0.011 \\
(1.37)\end{array}$ & $\begin{array}{l}0.011 \\
(1.38)\end{array}$ & $\begin{array}{l}0.002 \\
(0.50)\end{array}$ & $\begin{array}{c}0.002 \\
(0.53)\end{array}$ \\
\hline Constant & $\begin{array}{c}-51.917^{* * *} \\
(-5.13)\end{array}$ & $\begin{array}{c}-52.261^{* * *} \\
(-5.20)\end{array}$ & $\begin{array}{c}-12.415^{*} \\
(-1.88) \\
\end{array}$ & $\begin{array}{c}-12.420^{*} \\
(-1.88) \\
\end{array}$ \\
\hline Time Dummies & Yes & Yes & Yes & Yes \\
\hline Pension fund $\mathrm{FE}$ & Yes & Yes & Yes & Yes \\
\hline Observations & 2,331 & 2,331 & 2,331 & 2,331 \\
\hline$R^{2}$ & 0.944 & 0.944 & 0.066 & 0.066 \\
\hline
\end{tabular}

Notes: The table shows the results for the within-effect regression in Equation $2.3 \quad y_{i, t}=\alpha+X_{i, t} \beta+Z_{i, t} \gamma+\theta_{t}+$ $\mu_{i}+\epsilon_{i, t} . X_{i, t}$ is the set of pension fund characteristics, $Z_{i, t}$ is the set of board characteristics, and $\theta_{t}$ and $\mu_{i}$ are the time and pension fund fixed effects. The dependent variable $y_{i, t}$ in columns (1) - (2) is the net-of-fees yearly return on the equity portfolio in year $t$ for pension fund $i$. In columns (3) - (4) $y_{i, t}$ is the benchmark-adjusted yearly return on the equity portfolio. The benchmark-adjusted return is obtained by subtracting the benchmark return indicated by each pension fund from the net-of-fees yearly return on the equity portfolio. The board characteristics also include a dummy variable that equals one when a young trustee is hired and zero otherwise. A trustee is considered young if he or she is younger than 46 or 40 years old. The estimation relies on standard errors clustered at the pension fund level to correct for serial correlation. $t$ statistics in parentheses. ${ }^{*} p<0.1,{ }^{* *} p<0.05,{ }^{* * *} p<0.01$.

\subsection{Conclusion}

We use a unique database on the SAAs and the board of trustees of Dutch pension funds to study if pension fund trustees consider their own characteristics when they make investment decisions. Trustees have the fiduciary duty to invest pension fund 
assets in the best interests of the plan beneficiaries. Therefore, their own characteristics should not affect their decision-making. In contrast to these hypotheses, we find that the age, gender, and the employers affect the SAAs of pension funds.

Pension funds with more trustees of a high age allocate strategically less to equity. The effect of the trustees' age is strong in corporate pension funds, that is, in those pension funds in which trustees are also plan beneficiaries; while it is absent in pension funds in which trustees are more likely not to be beneficiaries. These findings have two non-mutually exclusive interpretations. On the one hand, trustees try to align the SAAs of pension funds with their own life-cycle investment objectives. On the other hand, trustees might unknowingly project their own preferences onto beneficiaries and as a result make biased decisions. Both explanations indicate that by considering their own age, trustees design SAAs that do not reflect the characteristics of all plan beneficiaries. We also find that pension funds with more females on their boards allocate less to equity.

Next, we find that corporate pension funds with a higher share of employer trustees in relation to participant trustees invest more in equity than corporate pension funds that have a lower share of employer trustees. Hence, the SAAs of pension funds in which the trustees of the employer have more power than the trustees of the participants tend to be riskier. This risk can be favorable to the employer, as the higher risk exposure increases the expected value of the assets, which the employer has a claim on. By safeguarding the interests of the employer, the trustees of the employer can receive career benefits. This behavior generates a principal-agent problem between the trustees and the beneficiaries, as a riskier allocation might not be in the beneficiaries' best interests. In the event of underfunding, beneficiaries may in fact face contribution increases or benefit reductions. A representation effect is not found in industry-wide pension funds that generally face greater scrutiny from the public that discourages trustees from valuing individual characteristics when they make investment decisions.

Trustees must act in the best interest of the plan beneficiaries and should not consider their own characteristics in making decisions on their behalf. The fact that 
trustees' characteristics correlate with the strategic equity allocation of pension funds indicates that trustees consider their own characteristics while carrying out their fiduciary duty. As a consequence, trustees might design SAAs that do not fully reflect beneficiaries' characteristics, hence possibly breaching their fiduciary duty. Our research shows the importance of pushing for greater diversity and better beneficiary representation on the pension funds' boards.

\section{A Swap Ratio}

Pension funds hedge interest rate risk using receiver swaps; however, the amount of interest risk that is hedged by each pension fund in this way is unobservable. Following Broeders et al. (2020), we model the total share of interest rate risk that is hedged via swaps: the so called swap hedge ratio. First, we assume that a pension fund with defined benefit liabilities invests only in equities and bonds. Second, we

model the pension liabilities as follows: Suppose we have a homogeneous group of beneficiaries that receive an annual pension payment of $P$. Each period a fraction of the beneficiaries dies. We express this by the annual mortality $\lambda$. These deaths lower the annual pension payments. Therefore, the level of pension payments in year $t$ is given by

$$
P \exp (-\lambda t)
$$

Third, we assume a flat term-structure of market interest rates $r$. We need this assumption to do the duration analysis later on. The present discounted value of all future pension liabilities equals:

$$
V=\int_{0}^{\infty} P \exp (-(r+\lambda) t) d t=\frac{P}{r+\lambda}
$$

The duration of the present discounted value of all future pension liabilities $V$ 
equals:

$$
D_{V}=-\frac{1}{V} \frac{d V}{d r}=\frac{1}{r+\lambda}
$$

This liability duration measures two things: (1) the weighted average time to maturity of the pension payments and (2) the sensitivity of the present discounted value of the pension liabilities to changes in market interest rates. Given that pension benefits stretch many decades, the duration is typically high.

Relative to its liabilities, a pension fund invests a fraction $\phi^{E}=\frac{E}{V}$ in equities and a fraction $B / V$ in bonds. The bonds have a duration of $D_{B}$. The fraction of interest rate risk embedded in the liabilities that is hedged with bonds is denoted by $\phi^{B}$. This bond hedge ratio is defined as:

$$
\phi^{B}=\frac{B}{V} \frac{D_{B}}{D_{V}} .
$$

In addition, the pension fund hedges interest rate risk through a portfolio of interest rate swaps. For simplicity we treat this hedging portfolio as a position in a single receiver swap in which the pension fund receives the swap rate (fixed leg) and pays a floating rate (floating leg) over a notional amount. We denote this notional of the receiver swap by $N$ and the duration of its fixed leg by $D_{R}$. The fraction of interest rate risk hedged via the receiver swap, relative to the total value of liabilities $V$, is the swap hedge ratio and is given by:

$$
\phi^{R}=\frac{N}{V} \frac{D_{R}}{D_{V}} .
$$

Pension funds have a capital requirement $S$ that is calculated such that the probability that the funding ratio falls below 100 percent on a one-year horizon equals 2.5 percent. This capital requirement translates into a funding requirement of $\frac{S+V}{V}$. 
Pension funds in the Netherlands determine the capital requirement by applying a method that is prescribed by law. For the purpose of this study we only consider how much capital is required for interest rate risk and equity risk. These two are the dominant risk factors in practice.

The interest rate risk is embedded in the present value of the future pension liabilities. If a pension fund hedges all interest rate risk, the capital requirement for this risk factor will be negligible. Therefore, the capital requirement is based on the part of the interest rate risk in the liabilities that is not hedged with swaps and bonds. To determine this part, we consider a decrease in the interest rate $\Delta r^{-}$. This decrease is prescribed by law. An interest rate decrease will typically lower the funding ratio. The increase in the value of the liabilities exceeds the increase in the value of fixed income assets.

The change in interest rates depends on the interest rate level, which in turn depends on the maturity. For our analysis we take the interest rate level for each pension fund with a maturity equal to the duration of its liabilities. Let us call this interest rate $r_{t, D_{V}}$. Second, the new interest rate level is equal to $r_{t, D_{V}}^{\prime}=\kappa r_{t, D_{V}}$. So that the absolute change in the interest rate is $\Delta r^{-}=r_{t, D_{V}}^{\prime}-r_{t, D_{V}}=\kappa r_{t, D_{V}}-r_{t, D_{V}}$. The multiplication factor $\kappa$ is described by law. Suppose the current market interest for a duration of 20 years is 4 percent and the multiplication factor is 0.76 . The absolute change in the interest rate is $0.76 * 0.04-0.04=0.01$ or 1 percent. The factors for $\kappa$ can be found here http://wetten.overheid.nl. The capital requirement for interest rate risk is given by:

$$
S_{1}=-\left(1-\phi^{R}-\phi^{B}\right) D_{V} \Delta r^{-}
$$

To keep the capital requirement from interest rate risk positive 2.9, we assume that pension funds never over-hedge, so that $\phi^{R}+\phi^{B} \leq 1$. This assumption is realistic as the value-weighted average of hedged interest rate risk across Dutch pension funds equals 40 percent, which means $\phi^{R}+\phi^{B}=0.40$. 
We are now be able to derive the swap hedge ratio $\phi^{R}$. Rewriting (2.9) gives

$$
\phi^{R}=1-\phi^{B}+\frac{S_{1}}{D_{V} \Delta r^{-}}
$$

The swap hedge ratio that we derive for each pension fund from Equation 2.10 is used as an additional control variable in our analysis. For the sake of completeness, we also provide the capital requirement for equity risk as a fraction of $V$ that is given by:

$$
S_{2}=\phi^{E} \Delta E
$$

where $\Delta E$ is a negative return on equity markets. This decrease is prescribed by law and equals -0.3 or minus 30 percent. We do not use this capital requirement for equity risk in our analysis.

\section{B Average age of active participants and fraction of retirees}

In this appendix we show that the average age of active participants and the fraction of retirees are interrelated. To show this relation we assume that the age distribution of beneficiaries follows a Gamma probability distribution. Figure 2-6] shows a hypothetical example of such an age distribution that assumes a Gamma distribution with shape parameter $\alpha=15.3$ and scale parameter $\beta=3.5$. The mean age of all beneficiaries is $(\alpha * \beta=) 52.4$ years old and the standard deviation is $(\beta \sqrt{\alpha}=) 13.5$ years. The mean age of active participants follows from numerically evaluating:

$$
\int_{0}^{z} x \frac{e^{\frac{-x}{\beta}} x^{-1+\alpha} \beta^{-\alpha}}{\Gamma(\alpha)} \mathrm{d} x
$$


where $\Gamma(\alpha)$ is the Gamma function. If we assume the retirement age to be $z=65$, the mean age of active participants equals 39.7 years old. Thus, the fraction of active participants follows from the cumulative distribution function. Consequently, the fraction of retirees is one minus the fraction of active participants. In the numerical example the fraction of retirees is 17.3 percent.

\section{Figure 2-6. Age distribution beneficiaries}

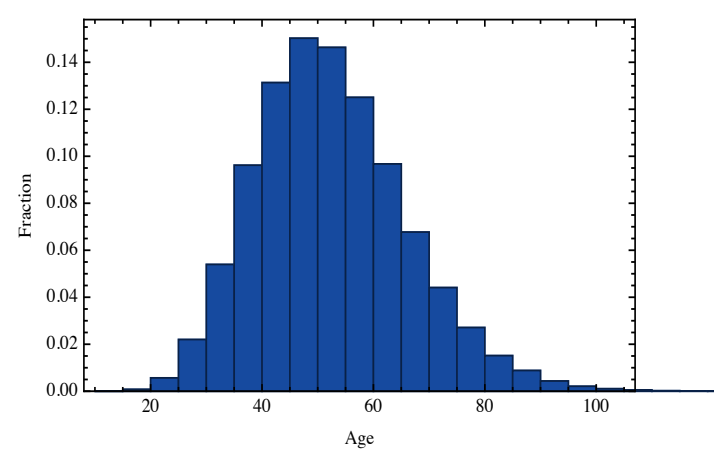

Notes: The figure shows the age distribution of the beneficiaries taking 200,000 random drawings from a Gamma distribution $\Gamma(15,3.5)$

Next, we analyze the effect of a younger or an older population of beneficiaries. We let the shape parameter $\alpha$ in the Gamma distribution range from 13 to 17 and keep the scale parameter fixed at $\beta=3.5$. By changing the shape parameter, the mean beneficiaries' age will vary from 45.5 to 59.5 years old. Figure 2-7 plots the mean age of active participants (solid line, left hand y-axis) and the fraction of retirees (dashed line, right hand y-axis), both as a function of the mean age of all beneficiaries. The mean age of active participants (mostly) goes down if the beneficiaries as a group get older. This is due to the fact that we measure the conditional probability distribution below the retirement age. The fraction of retirees goes up with the mean age of all beneficiaries. The correlation between the mean age of active participants and the fraction of retirees is -0.96 . This correlation therefore shows that the mean age of active participants is also informative about the fraction of retirees. 


\section{Figure 2-7. Average age active participants and fraction of retirees}

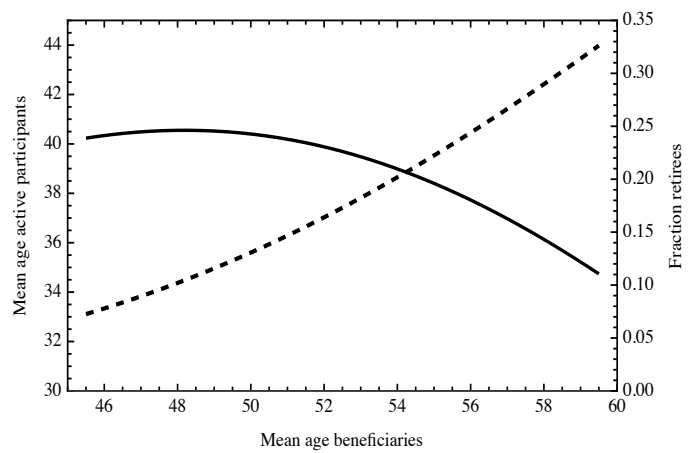

Notes: The figure shows the mean age of active participants (solid line, left hand y-axis) and the fraction of retirees (dashed line, right hand y-axis) as a function of the mean age of all beneficiaries. We assume a Gamma distribution $\Gamma(\alpha, 3.5)$ where $\alpha$ ranges from 13 to 17 . This is equivalent to a mean beneficiaries' age ranging from 45.5 to 59.5 years old.

\section{C Role of the median voter in the board}

The "median voter" plays a key role in majoritarian decision-making. We therefore test the effect of the median age of the board on investment decisions. There is no rule in the Dutch Pension Act that prescribes how decisions are made by the board. The decision-making is arranged in the statute of each pension fund. However, many pension funds have a majoritarian decision-making. In practice, trustees normally entertain some discussions to reach a consensus among all the members.

Within the framework of majoritarian decision-making, one basic way of modeling the decisional process is represented by the median voter theorem (Hotelling (1929); Black (1948); Downs (1957)). The median voter model is typically used by political theorists and political economists to explain the political outcomes in a democracy as a reflection of the median voter preferences (Alesina and Cukierman 1990); Alesina et al. (1993) Wijnbergen (1992)). In its weak form, the median voter theorem means that in a two party system, the winning party is the one that is closer to the median voter preference (Congleton (2004)).

To understand the logic of the median voter model and its application to the board of trustees of a pension fund, we consider a simplified setting with three trustees: 
Table 2.8: Voting outcomes under the median voting theorem

\begin{tabular}{llllc}
\hline \hline Options & \multicolumn{3}{c}{ Pattern of votes } & Results \\
\hline 40 vs. 25 & A: 40 & B: 25 & C: 25 & 25 \\
40 vs. 30 & A: 40 & B: 30 & C: 30 & 30 \\
40 vs. 20 & A: 40 & B: 20 & C: 20 & 20 \\
35 vs. 10 & A: 35 & B: 35 & C: 10 & 35 \\
33 vs. 12 & A: 33 & B: 33 & C: 12 & 33 \\
\hline \hline
\end{tabular}

Anna, Bart, and Carl that have to make a decision on the strategic equity allocation. Moreover, assume that even though they are required to represent all beneficiaries, they also have personal investment preferences related to their age. It follows that their age will affect their voting preferences. Anna is relatively young, say 40 years old, and she prefers to allocate 40 percent of the portfolio to equity. Bart is middle age, say 50 years old, and prefers a more conservative 25 percent allocation. Carl is older, say 60 years old, and given that his retirement is approaching he wants to have a safe portfolio. He prefers to allocate only 20 percent of the portfolio to equity. In this example, Bart is said to be the median voter because exactly the same number of individuals prefer a more aggressive SAA than him as prefer a more conservative SAA than him. Each of the three trustees prefers the equity allocation that is closest to their preferred allocation. Table 2.8 presents the majority decision in different scenarios using purely arbitrary numbers. The choices between two equity allocations that the board has to decide on are listed in the first column. The vote of each trustee (in line with their preference) is listed in the second column. The equity allocations that are selected by the board are listed in the third column.

In line with the weak form of the median voter theorem, the median voter (Bart) always casts his vote for the allocation to equity that is eventually approved. If this is known to the other two board members, both of them will converge to the median vote position. It follows that at the limit both young and old trustees will propose the same equity allocation, which is the one preferred by the median voter. Given that the median voter always succeeds in having his or her preferred option approved, then anything that affects the median voter's assessment can also affect the final outcome of the board's decision (Congleton (2004)). For example, if the age of the median voter can affect the median voter's assessment of the investment policy discussed in 
a board meeting, then it can consequently affect the board's decision.

\section{D Internet Appendix}

\section{D.1 Summary statistics at the trustee level}

In this section, we present the summary statistics of the characteristics of trustees. The unit of observation is an individual trustee rather than pension funds, as in the study. Next, we present the correlation between the demographics of board members and the demographics of participants.

Table 2.9: Summary statistics at trustees level

\begin{tabular}{lccccccc}
\hline \hline & Obs & Mean & Std. Dev. & Min & $25^{t h}$ & $75^{t h}$ & Max \\
\hline Trustee Age & 20,625 & 53.59 & 10.24 & 19.00 & 46.00 & 61.00 & 85.00 \\
Female Trustee & 26,708 & 0.11 & 0.31 & 0.00 & 0.00 & 0.00 & 1.00 \\
Tenure & 26,243 & 5.30 & 5.44 & 0.00 & 1.00 & 8.00 & 41.00 \\
University Degree & 12,913 & 0.68 & 0.47 & 0.00 & 0.00 & 1.00 & 1.00 \\
Public Background & 12,987 & 0.15 & 0.35 & 0.00 & 0.00 & 0.00 & 1.00 \\
Finance Background & 13,007 & 0.34 & 0.47 & 0.00 & 0.00 & 1.00 & 1.00 \\
Employer Representative & 26,708 & 0.45 & 0.50 & 0.00 & 0.00 & 1.00 & 1.00 \\
Pensioners Representative & 26,708 & 0.11 & 0.32 & 0.00 & 0.00 & 0.00 & 1.00 \\
Employees Representative & 26,708 & 0.39 & 0.49 & 0.00 & 0.00 & 1.00 & 1.00 \\
Independent Trustee & 26,708 & 0.03 & 0.17 & 0.00 & 0.00 & 0.00 & 1.00 \\
Former Employees Representative & 26,708 & 0.01 & 0.09 & 0.00 & 0.00 & 0.00 & 1.00 \\
\hline \hline
\end{tabular}

Table 2.10: Correlation matrix age board and participants age

\begin{tabular}{lcccccc}
\hline \hline & $\begin{array}{c}\text { Avg. Age } \\
\text { Active Part. }\end{array}$ & $\begin{array}{c}\text { Avg. Age } \\
\text { Tot. Part. }\end{array}$ & $\begin{array}{c}\text { Board } \\
\text { Avg. Age }\end{array}$ & $\begin{array}{c}\% \text { Trustees } \\
(<40)\end{array}$ & $\begin{array}{c}\text { \% Trustees } \\
(<46)\end{array}$ & $\begin{array}{c}\text { Board } \\
\text { Median Age }\end{array}$ \\
\hline Avg. Age Active Part. & 1 & & & & & \\
Avg. Age Tot. Part. & $0.636^{* * *}$ & 1 & & & & \\
Board Avg. Age & $0.191^{* * *}$ & $0.279^{* * *}$ & 1 & & & \\
$\%$ Trustees $(<40)$ & $-0.147^{* * *}$ & $-0.112^{* * *}$ & $-0.572^{* * *}$ & 1 & & \\
$\%$ Trustees $(<46)$ & $-0.151^{* * *}$ & $-0.151^{* * *}$ & $-0.648^{* * *}$ & $0.714^{* * *}$ & 1 & \\
Board Median Age & $0.162^{* * *}$ & $0.225^{* * *}$ & $0.936^{* * *}$ & $-0.521^{* * *}$ & $-0.639^{* * *}$ & 1 \\
\hline \hline
\end{tabular}

\section{D.2 Summary statistics corporate vs non-corporate pension funds}


Table 2.11: Summary statistics corporate pension funds

\begin{tabular}{|c|c|c|c|c|c|c|c|}
\hline & Obs & Mean & Std. Dev. & Min & $25^{t h}$ & $75^{t h}$ & $\operatorname{Max}$ \\
\hline \multicolumn{8}{|l|}{ A. Asset Allocation } \\
\hline Fixed Income & 2124 & 61.31 & 14.34 & 9.00 & 50.45 & 70.00 & 100.00 \\
\hline Equity & 2124 & 30.15 & 12.00 & 0.00 & 22.50 & 37.50 & 80.00 \\
\hline Real Estate & 2124 & 4.81 & 5.28 & 0.00 & 0.00 & 8.00 & 50.00 \\
\hline Private Equity & 2124 & 0.52 & 1.61 & 0.00 & 0.00 & 0.00 & 12.20 \\
\hline Hedge Funds & 2124 & 1.16 & 3.02 & 0.00 & 0.00 & 0.00 & 40.00 \\
\hline Commodities & 2124 & 0.87 & 2.03 & 0.00 & 0.00 & 0.00 & 22.50 \\
\hline Other Assets & 2124 & 0.46 & 2.01 & 0.00 & 0.00 & 0.00 & 25.00 \\
\hline Cash & 2124 & 0.70 & 3.88 & 0.00 & 0.00 & 0.00 & 90.60 \\
\hline \multicolumn{8}{|l|}{ B. Pension Fund Characteristics } \\
\hline Funding Ratio & 2101 & 114.24 & 29.34 & 83.60 & 100.70 & 118.10 & 323.80 \\
\hline Assets Under Management (Million) & 2117 & 897.78 & 2609.76 & 0.00 & 70.17 & 573.92 & 27461.16 \\
\hline Total Yearly Return & 2124 & 5.75 & 8.00 & -21.82 & 1.80 & 11.10 & 21.40 \\
\hline Total Bmk. Adj. Return & 2124 & -0.02 & 2.81 & -9.20 & -1.00 & 0.86 & 9.30 \\
\hline Equity Yearly Return & 2124 & 5.22 & 20.81 & -55.79 & 0.00 & 16.50 & 36.40 \\
\hline Equity Bmk. Adj. Return & 2124 & 0.10 & 3.31 & -12.10 & -1.07 & 1.00 & 13.20 \\
\hline Average Age Active Participants & 2055 & 45.48 & 4.14 & 33.97 & 43.03 & 47.92 & 62.50 \\
\hline Average Age Retirees & 2088 & 69.61 & 5.73 & 35.45 & 66.76 & 73.43 & 87.67 \\
\hline Average Age Former Participants & 2073 & 47.36 & 4.40 & 30.21 & 44.54 & 50.37 & 67.50 \\
\hline Average Age Tot. Participants & 2093 & 52.81 & 7.73 & 33.33 & 47.54 & 57.74 & 82.89 \\
\hline Liablity Duration & 2055 & 17.11 & 3.95 & 6.10 & 14.80 & 19.10 & 30.10 \\
\hline$\%$ Active Participants & 2055 & 35.54 & 17.69 & 0.18 & 24.06 & 45.77 & 99.87 \\
\hline$\%$ Retirees & 2088 & 26.14 & 18.62 & 0.02 & 11.98 & 37.29 & 100.00 \\
\hline$\%$ Former Participants & 2073 & 39.41 & 14.78 & 0.04 & 30.22 & 47.98 & 100.00 \\
\hline \multicolumn{8}{|l|}{ C. Board of Trustees } \\
\hline Board Size & 2070 & 6.74 & 2.36 & 1.00 & 5.00 & 8.00 & 20.00 \\
\hline Board Average Age & 2023 & 52.50 & 5.87 & 26.00 & 49.00 & 56.40 & 73.00 \\
\hline Diff. Age Board vs. Participants & 1,981 & 6.87 & 6.26 & -27.36 & 3.22 & 11.00 & 29.45 \\
\hline Board Average Tenure & 2044 & 5.32 & 2.97 & 0.00 & 3.20 & 6.80 & 22.75 \\
\hline$\%$ Female Trustees & 2070 & 10.08 & 12.35 & 0.00 & 0.00 & 16.67 & 100.00 \\
\hline \% Employer Trustees & 2070 & 46.17 & 11.57 & 0.00 & 42.86 & 50.00 & 100.00 \\
\hline \% Retirees Trustees & 2070 & 13.92 & 12.00 & 0.00 & 0.00 & 20.00 & 100.00 \\
\hline \% Employees Trustees & 2070 & 36.96 & 12.98 & 0.00 & 30.00 & 50.00 & 100.00 \\
\hline \% Independent Trustees & 2070 & 1.83 & 8.22 & 0.00 & 0.00 & 0.00 & 100.00 \\
\hline \% Former Employees Trustees & 2070 & 0.53 & 4.94 & 0.00 & 0.00 & 0.00 & 100.00 \\
\hline$\%$ Young Trustees (Age $<40$ ) & 2023 & 10.18 & 13.24 & 0.00 & 0.00 & 16.67 & 100.00 \\
\hline$\%$ Young Trustees (Age $<46$ ) & 2023 & 20.76 & 17.85 & 0.00 & 0.00 & 33.33 & 100.00 \\
\hline \% University Degree & 2070 & 36.71 & 26.15 & 0.00 & 16.67 & 54.55 & 100.00 \\
\hline$\%$ Public Background & 2070 & 1.13 & 5.35 & 0.00 & 0.00 & 0.00 & 71.43 \\
\hline$\%$ Finance Background & 2070 & 20.69 & 19.78 & 0.00 & 0.00 & 33.33 & 100.00 \\
\hline
\end{tabular}

Notes: Panel A. presents information about pension funds' asset allocation, Panel B about pension funds' characteristics, and Panel $\mathrm{C}$ about the boards of trustees. The mean (standard deviation) indicates the average (standard deviation) across pension funds and over time for each variable. All numbers are expressed as percentages unless otherwise stated and are computed relying on yearly information. Quarterly returns are compounded to obtain yearly returns. Strategic asset allocation, funding ratio, and assets under management figures are based on the reported values in the last quarter of each year. For some of the variables, e.g., assets under management, allocation to hedge funds, and private equity, the mean is outside the $25 \%-75 \%$ interval. This is due to the skewness of the distribution. In column Max, the exceptionally high values are reported for hedge funds, commodities, other assets, and cash. These are special cases of pension funds under the process of liquidation or merger. The values are not persistent over time and do not affect the results of our analysis. 
Table 2.12: Summary statistics non-corporate pension funds

\begin{tabular}{|c|c|c|c|c|c|c|c|}
\hline & Obs & Mean & Std. Dev. & Min & $25^{t h}$ & $75^{t h}$ & Max \\
\hline \multicolumn{8}{|l|}{ A. Asset Allocation } \\
\hline Fixed Income & 733 & 57.69 & 14.10 & 16.50 & 47.00 & 68.00 & 100.00 \\
\hline Equity & 733 & 28.86 & 10.24 & 0.00 & 21.80 & 35.10 & 61.00 \\
\hline Real Estate & 733 & 8.42 & 6.76 & 0.00 & 4.00 & 12.00 & 51.82 \\
\hline Private Equity & 733 & 1.14 & 1.90 & 0.00 & 0.00 & 1.50 & 11.20 \\
\hline Hedge Funds & 733 & 0.96 & 1.95 & 0.00 & 0.00 & 0.50 & 10.87 \\
\hline Commodities & 733 & 1.44 & 2.02 & 0.00 & 0.00 & 2.70 & 10.00 \\
\hline Other Assets & 733 & 0.64 & 2.12 & 0.00 & 0.00 & 0.00 & 38.30 \\
\hline Cash & 733 & 0.70 & 2.62 & 0.00 & 0.00 & 0.50 & 34.90 \\
\hline \multicolumn{8}{|l|}{ B. Pension Fund Characteristics } \\
\hline Funding Ratio & 730 & 112.66 & 27.46 & 83.60 & 99.10 & 114.20 & 323.80 \\
\hline Assets Under Management (Million) & 733 & 8439.03 & 34914.68 & 0.07 & 261.33 & 3026.28 & 380976.00 \\
\hline Total Yearly Return & 733 & 5.54 & 8.10 & -21.82 & 2.00 & 11.00 & 21.40 \\
\hline Total Bmk. Adj. Return & 733 & 0.11 & 2.45 & -9.20 & -0.50 & 0.80 & 9.30 \\
\hline Equity Yearly Return & 733 & 5.45 & 20.49 & -55.79 & 1.14 & 15.80 & 36.40 \\
\hline Equity Bmk. Adj. Return & 733 & -0.06 & 2.44 & -12.10 & -0.60 & 0.77 & 13.20 \\
\hline Average Age Active Participants & 704 & 43.68 & 4.99 & 32.72 & 40.99 & 45.46 & 63.21 \\
\hline Average Age Retirees & 729 & 70.34 & 4.28 & 36.13 & 68.43 & 72.91 & 82.45 \\
\hline Average Age Former Participants & 727 & 47.15 & 4.97 & 37.08 & 43.75 & 49.63 & 67.50 \\
\hline Average Age Tot. Participants & 729 & 50.46 & 7.24 & 36.48 & 45.74 & 54.26 & 82.03 \\
\hline Liablity Duration & 726 & 18.81 & 4.67 & 6.10 & 16.20 & 21.40 & 30.10 \\
\hline$\%$ Active Participants & 704 & 30.95 & 16.46 & 0.00 & 20.10 & 40.20 & 99.91 \\
\hline$\%$ Retirees & 729 & 19.43 & 16.93 & 0.09 & 8.51 & 24.84 & 98.19 \\
\hline$\%$ Former Participants & 727 & 50.82 & 21.17 & 0.01 & 35.67 & 65.49 & 97.42 \\
\hline \multicolumn{8}{|l|}{ C. Board of Trustees } \\
\hline Board Size & 724 & 8.14 & 2.56 & 2.00 & 6.00 & 10.00 & 20.00 \\
\hline Board Average Age & 713 & 54.52 & 4.69 & 33.75 & 52.00 & 57.56 & 69.00 \\
\hline Diff. Age Board vs. Participants & 688 & 10.83 & 5.99 & -21.06 & 7.87 & 14.46 & 30.21 \\
\hline Board Average Tenure & 720 & 5.15 & 2.60 & 0.00 & 3.33 & 6.59 & 17.63 \\
\hline$\%$ Female Trustees & 724 & 13.97 & 15.77 & 0.00 & 0.00 & 22.22 & 100.00 \\
\hline \% Employer Trustees & 724 & 43.94 & 18.17 & 0.00 & 40.83 & 50.00 & 100.00 \\
\hline$\%$ Retirees Trustees & 724 & 4.91 & 10.36 & 0.00 & 0.00 & 8.33 & 100.00 \\
\hline \% Employees Trustees & 724 & 43.47 & 19.34 & 0.00 & 37.50 & 50.00 & 100.00 \\
\hline \% Independent Trustees & 724 & 6.55 & 19.49 & 0.00 & 0.00 & 0.00 & 100.00 \\
\hline \% Former Employees Trustees & 724 & 0.80 & 5.99 & 0.00 & 0.00 & 0.00 & 80.00 \\
\hline \% Young Trustees $($ Age $<40)$ & 713 & 5.53 & 9.29 & 0.00 & 0.00 & 11.11 & 60.00 \\
\hline \% Young Trustees $($ Age $<46)$ & 713 & 13.99 & 13.71 & 0.00 & 0.00 & 20.00 & 80.00 \\
\hline \% University Degree & 724 & 34.88 & 25.57 & 0.00 & 15.38 & 50.00 & 100.00 \\
\hline \% Public Background & 724 & 25.63 & 19.15 & 0.00 & 12.50 & 37.50 & 100.00 \\
\hline$\%$ Finance Background & 724 & 11.19 & 14.28 & 0.00 & 0.00 & 16.67 & 80.00 \\
\hline
\end{tabular}

Notes: Panel A presents information about pension funds' asset allocation, Panel B about pension funds' characteristics, and Panel $\mathrm{C}$ about the boards of trustees. The mean (standard deviation) indicates the average (standard deviation) across pension funds and over time for each variable. All numbers are expressed as percentages unless otherwise stated and are computed relying on yearly information. Quarterly returns are compounded to obtain yearly returns. Strategic asset allocation, funding ratio, and assets under management figures are based on the reported values in the last quarter of each year. For some of the variables, e.g., assets under management, allocation to hedge funds, and private equity, the mean is outside the $25 \%-75 \%$ interval. This is due to the skewness of the distribution. In column Max, the exceptionally high values are reported for hedge funds, commodities, other assets, and cash. These are special cases of pension funds under the process of liquidation or merger. The values are not persistent over time and do not affect the results of our analysis. 


\section{D.3 Effect of board characteristics on the risky assets port- folio}

Table 2.13: The effect of board characteristics on the risky assets allocation

\begin{tabular}{|c|c|c|c|c|}
\hline & $(1)$ & $(2)$ & $(3)$ & (4) \\
\hline Board Average Age & $\begin{array}{c}-0.183^{*} \\
(-1.78)\end{array}$ & & & \\
\hline Board Median Age & & $\begin{array}{c}-0.193^{* *} \\
(-2.11)\end{array}$ & & \\
\hline \% Young Trustees $($ Age $<46)$ & & & $\begin{array}{l}0.031 \\
(1.02)\end{array}$ & \\
\hline \% Young Trustees $($ Age $<40$ ) & & & & $\begin{array}{l}0.040 \\
(1.07)\end{array}$ \\
\hline Board Size & $\begin{array}{c}0.682^{* *} \\
(2.42)\end{array}$ & $\begin{array}{c}0.678^{* *} \\
(2.42)\end{array}$ & $\begin{array}{c}0.686^{* *} \\
(2.43)\end{array}$ & $\begin{array}{c}0.692^{* *} \\
(2.46)\end{array}$ \\
\hline Board Average Tenure & $\begin{array}{l}0.365^{*} \\
(1.81)\end{array}$ & $\begin{array}{l}0.370^{*} \\
(1.83)\end{array}$ & $\begin{array}{l}0.341^{*} \\
(1.70)\end{array}$ & $\begin{array}{l}0.341^{*} \\
(1.70)\end{array}$ \\
\hline$\%$ Female Trustees & $\begin{array}{l}-0.030 \\
(-0.77)\end{array}$ & $\begin{array}{l}-0.031 \\
(-0.81)\end{array}$ & $\begin{array}{l}-0.026 \\
(-0.68)\end{array}$ & $\begin{array}{l}-0.025 \\
(-0.66)\end{array}$ \\
\hline \% Employer Trustees & $\begin{array}{l}0.008 \\
(0.17)\end{array}$ & $\begin{array}{l}0.007 \\
(0.15)\end{array}$ & $\begin{array}{l}0.013 \\
(0.28)\end{array}$ & $\begin{array}{l}0.013 \\
(0.29)\end{array}$ \\
\hline$\%$ Retirees Trustees & $\begin{array}{l}0.030 \\
(0.58)\end{array}$ & $\begin{array}{l}0.028 \\
(0.55)\end{array}$ & $\begin{array}{l}0.023 \\
(0.45)\end{array}$ & $\begin{array}{l}0.024 \\
(0.46)\end{array}$ \\
\hline \% External (independent) Trustees & $\begin{array}{l}0.034 \\
(1.04)\end{array}$ & $\begin{array}{l}0.034 \\
(1.04)\end{array}$ & $\begin{array}{l}0.035 \\
(1.07)\end{array}$ & $\begin{array}{l}0.036 \\
(1.09)\end{array}$ \\
\hline \% University Degree & $\begin{array}{l}0.007 \\
(0.24)\end{array}$ & $\begin{array}{l}0.006 \\
(0.22)\end{array}$ & $\begin{array}{l}0.007 \\
(0.25)\end{array}$ & $\begin{array}{l}0.008 \\
(0.27)\end{array}$ \\
\hline \% Public Background & $\begin{array}{l}0.030 \\
(0.57)\end{array}$ & $\begin{array}{l}0.033 \\
(0.62)\end{array}$ & $\begin{array}{l}0.028 \\
(0.53)\end{array}$ & $\begin{array}{l}0.027 \\
(0.51)\end{array}$ \\
\hline$\%$ Finance Background & $\begin{array}{c}-0.081^{* *} \\
(-2.16)\end{array}$ & $\begin{array}{c}-0.085^{* *} \\
(-2.28)\end{array}$ & $\begin{array}{c}-0.078^{* *} \\
(-2.07)\end{array}$ & $\begin{array}{c}-0.076^{* *} \\
(-2.03)\end{array}$ \\
\hline Average Age Active Participants & $\begin{array}{c}-0.554^{* * *} \\
(-3.90)\end{array}$ & $\begin{array}{c}-0.551^{* * *} \\
(-3.88)\end{array}$ & $\begin{array}{c}-0.564^{* * *} \\
(-3.94)\end{array}$ & $\begin{array}{c}-0.562^{* * *} \\
(-3.90)\end{array}$ \\
\hline$\%$ Retirees & $\begin{array}{l}0.072 \\
(1.57)\end{array}$ & $\begin{array}{l}0.071 \\
(1.57)\end{array}$ & $\begin{array}{l}0.067 \\
(1.45)\end{array}$ & $\begin{array}{l}0.065 \\
(1.42)\end{array}$ \\
\hline Log Size & $\begin{array}{c}2.373^{* * *} \\
(5.37)\end{array}$ & $\begin{array}{c}2.390^{* * *} \\
(5.48)\end{array}$ & $\begin{array}{c}2.341^{* * *} \\
(5.33)\end{array}$ & $\begin{array}{c}2.326^{* * *} \\
(5.21)\end{array}$ \\
\hline Lag Funding Ratio & $\begin{array}{c}0.080^{* * * *} \\
(3.32)\end{array}$ & $\begin{array}{c}0.079^{* * *} \\
(3.35)\end{array}$ & $\begin{array}{c}0.078^{* * *} \\
(3.23)\end{array}$ & $\begin{array}{c}0.078^{* * * *} \\
(3.25)\end{array}$ \\
\hline Swap Ratio & $\begin{array}{c}0.064^{* *} \\
(2.57)\end{array}$ & $\begin{array}{c}0.065^{* *} \\
(2.59)\end{array}$ & $\begin{array}{c}0.065^{* * *} \\
(2.60)\end{array}$ & $\begin{array}{c}0.066^{* * *} \\
(2.64)\end{array}$ \\
\hline Professional Pension Funds. & $\begin{array}{l}-3.469 \\
(-0.99)\end{array}$ & $\begin{array}{l}-3.531 \\
(-1.02)\end{array}$ & $\begin{array}{l}-3.304 \\
(-0.94)\end{array}$ & $\begin{array}{l}-3.230 \\
(-0.91)\end{array}$ \\
\hline Industry Pension Funds. & $\begin{array}{c}-3.717^{*} \\
(-1.69)\end{array}$ & $\begin{array}{c}-3.674^{*} \\
(-1.68)\end{array}$ & $\begin{array}{l}-3.880^{*} \\
(-1.78)\end{array}$ & $\begin{array}{l}-3.878^{*} \\
(-1.78)\end{array}$ \\
\hline Constant & $\begin{array}{c}29.346^{* * *} \\
(3.03) \\
\end{array}$ & $\begin{array}{c}29.654^{* * *} \\
(3.12) \\
\end{array}$ & $\begin{array}{c}20.803^{* *} \\
(2.26) \\
\end{array}$ & $\begin{array}{c}21.010^{* *} \\
(2.28) \\
\end{array}$ \\
\hline Time Dummies & Yes & Yes & Yes & Yes \\
\hline Observations & 2392 & 2392 & 2392 & 2392 \\
\hline$R^{2}$ & 0.205 & 0.207 & 0.203 & 0.203 \\
\hline
\end{tabular}

Notes: The table shows the results for the pooled OLS in Equation (2.1) in the thesis: $y_{i, t}=\alpha+X_{i, t} \beta+Z_{i, t} \gamma+\theta_{t}+\epsilon_{i, t}$. The dependent variable $y_{i, t}$ is the strategic risky assets allocation of pension fund $i$ in year $t$. Where risky assets is the sum of equity, hedge funds, commodities, private equity and real estate. $t$ statistics in parentheses. ${ }^{*} p<0.1,{ }^{* *}$ $p<0.05,{ }^{* * *} p<0.01$. 


\section{D.4 Effect of board characteristics on the fixed income port- folio}

Table 2.14: Board characteristics and the strategic fixed income allocation

\begin{tabular}{|c|c|c|c|c|}
\hline & $(1)$ & $(2)$ & (3) & $(4)$ \\
\hline Board Average Age & $\begin{array}{c}0.223^{* *} \\
(2.53)\end{array}$ & & & \\
\hline Board Median Age & & $\begin{array}{c}0.189^{* *} \\
(2.37)\end{array}$ & & \\
\hline$\%$ Young Trustees $($ Age $<46)$ & & & $\begin{array}{l}-0.046^{*} \\
(-1.78)\end{array}$ & \\
\hline$\%$ Young Trustees $($ Age $<40$ ) & & & & $\begin{array}{l}-0.047 \\
(-1.39)\end{array}$ \\
\hline Board Size & $\begin{array}{l}-0.329 \\
(-1.36)\end{array}$ & $\begin{array}{l}-0.327 \\
(-1.36)\end{array}$ & $\begin{array}{l}-0.333 \\
(-1.37)\end{array}$ & $\begin{array}{l}-0.341 \\
(-1.41)\end{array}$ \\
\hline Board Average Tenure & $\begin{array}{l}-0.042 \\
(-0.23)\end{array}$ & $\begin{array}{l}-0.034 \\
(-0.18)\end{array}$ & $\begin{array}{l}-0.020 \\
(-0.11)\end{array}$ & $\begin{array}{l}-0.010 \\
(-0.06)\end{array}$ \\
\hline$\%$ Female Trustees & $\begin{array}{l}0.045 \\
(1.46)\end{array}$ & $\begin{array}{l}0.045 \\
(1.45)\end{array}$ & $\begin{array}{l}0.041 \\
(1.37)\end{array}$ & $\begin{array}{c}0.039 \\
(1.29)\end{array}$ \\
\hline \% Employer Trustees & $\begin{array}{l}-0.036 \\
(-0.90)\end{array}$ & $\begin{array}{l}-0.035 \\
(-0.90)\end{array}$ & $\begin{array}{l}-0.042 \\
(-1.06)\end{array}$ & $\begin{array}{l}-0.042 \\
(-1.05)\end{array}$ \\
\hline$\%$ Retirees Trustees & $\begin{array}{l}-0.003 \\
(-0.07)\end{array}$ & $\begin{array}{l}0.001 \\
(0.03)\end{array}$ & $\begin{array}{l}0.003 \\
(0.07)\end{array}$ & $\begin{array}{l}0.004 \\
(0.09)\end{array}$ \\
\hline$\%$ Independent Trustees & $\begin{array}{l}0.006 \\
(0.23)\end{array}$ & $\begin{array}{l}0.006 \\
(0.23)\end{array}$ & $\begin{array}{l}0.004 \\
(0.17)\end{array}$ & $\begin{array}{l}0.004 \\
(0.15)\end{array}$ \\
\hline$\%$ University Degree & $\begin{array}{l}-0.025 \\
(-0.97)\end{array}$ & $\begin{array}{l}-0.024 \\
(-0.97)\end{array}$ & $\begin{array}{l}-0.024 \\
(-0.96)\end{array}$ & $\begin{array}{l}-0.026 \\
(-1.01)\end{array}$ \\
\hline$\%$ Public Background & $\begin{array}{l}0.011 \\
(0.24)\end{array}$ & $\begin{array}{l}0.009 \\
(0.20)\end{array}$ & $\begin{array}{l}0.012 \\
(0.28)\end{array}$ & $\begin{array}{l}0.014 \\
(0.31)\end{array}$ \\
\hline$\%$ Finance Background & $\begin{array}{c}0.093^{* * *} \\
(2.83)\end{array}$ & $\begin{array}{c}0.095^{* * *} \\
(2.90)\end{array}$ & $\begin{array}{c}0.091^{* * *} \\
(2.75)\end{array}$ & $\begin{array}{c}0.088^{* * *} \\
(2.64)\end{array}$ \\
\hline Average Age Active Participants & $\begin{array}{c}0.302^{* *} \\
(2.26)\end{array}$ & $\begin{array}{c}0.306^{* *} \\
(2.29)\end{array}$ & $\begin{array}{c}0.309^{* *} \\
(2.30)\end{array}$ & $\begin{array}{c}0.313^{* *} \\
(2.33)\end{array}$ \\
\hline$\%$ Retirees & $\begin{array}{l}-0.028 \\
(-0.66)\end{array}$ & $\begin{array}{l}-0.027 \\
(-0.63)\end{array}$ & $\begin{array}{l}-0.022 \\
(-0.50)\end{array}$ & $\begin{array}{l}-0.021 \\
(-0.48)\end{array}$ \\
\hline Log Size & $\begin{array}{c}-1.477^{* * *} \\
(-3.59)\end{array}$ & $\begin{array}{c}-1.466^{* * *} \\
(-3.58)\end{array}$ & $\begin{array}{c}-1.461^{* * *} \\
(-3.60)\end{array}$ & $\begin{array}{c}-1.416^{* * *} \\
(-3.42)\end{array}$ \\
\hline Lag Funding Ratio & $\begin{array}{c}-0.092^{* * *} \\
(-4.35)\end{array}$ & $\begin{array}{c}-0.091^{* * *} \\
(-4.36)\end{array}$ & $\begin{array}{c}-0.089^{* * *} \\
(-4.27)\end{array}$ & $\begin{array}{c}-0.090^{* * *} \\
(-4.31)\end{array}$ \\
\hline Swap Ratio & $\begin{array}{c}-0.040^{*} \\
(-1.83)\end{array}$ & $\begin{array}{l}-0.041^{*} \\
(-1.87)\end{array}$ & $\begin{array}{l}-0.041^{*} \\
(-1.85)\end{array}$ & $\begin{array}{c}-0.042^{*} \\
(-1.91)\end{array}$ \\
\hline Professional Pension Funds. & $\begin{array}{l}0.715 \\
(0.26)\end{array}$ & $\begin{array}{l}0.718 \\
(0.26)\end{array}$ & $\begin{array}{l}0.536 \\
(0.19)\end{array}$ & $\begin{array}{l}0.424 \\
(0.15)\end{array}$ \\
\hline Industry Pension Funds. & $\begin{array}{c}3.991^{* *} \\
(2.12)\end{array}$ & $\begin{array}{c}4.010^{* *} \\
(2.13)\end{array}$ & $\begin{array}{c}4.165^{* *} \\
(2.21)\end{array}$ & $\begin{array}{c}4.193^{* *} \\
(2.22)\end{array}$ \\
\hline Constant & $\begin{array}{c}70.950^{* * *} \\
(8.49) \\
\end{array}$ & $\begin{array}{c}72.122^{* * *} \\
(8.80) \\
\end{array}$ & $\begin{array}{c}82.015^{* * *} \\
(10.56) \\
\end{array}$ & $\begin{array}{c}80.981^{* * *} \\
(10.29) \\
\end{array}$ \\
\hline Time Dummies & Yes & Yes & Yes & Yes \\
\hline Observations & 2392 & 2392 & 2392 & 2392 \\
\hline$R^{2}$ & 0.127 & 0.127 & 0.124 & 0.122 \\
\hline
\end{tabular}

Notes: The table shows the results for the pooled OLS in Equation 2.1: $y_{i, t}=\alpha+X_{i, t} \beta+Z_{i, t} \gamma+\theta_{t}+\epsilon_{i, t} . y_{i, t}$ is the portfolio share of fixed income for pension fund $i$ in year $t . X_{i, t}$ and $Z_{i, t}$ are pension fund and board characteristics. Standard errors are clustered at the pension fund level. 
Table 2.15: The effect of young trustees on fixed income allocation

\begin{tabular}{|c|c|c|c|c|c|c|}
\hline & $(1)$ & $(2)$ & $(3)$ & (4) & $(5)$ & (6) \\
\hline$\%$ Young Trustees $($ Age $<46)$ & $\begin{array}{c}-0.046^{*} \\
(-1.78)\end{array}$ & $\begin{array}{l}-0.025 \\
(-0.93)\end{array}$ & $\begin{array}{l}-0.003 \\
(-0.11)\end{array}$ & & & \\
\hline Age Representation Gap & & $\begin{array}{l}1.717^{*} \\
(1.95)\end{array}$ & $\begin{array}{c}3.085^{* *} \\
(2.58)\end{array}$ & & $\begin{array}{c}1.918^{* *} \\
(2.17)\end{array}$ & $\begin{array}{c}2.724^{* * *} \\
(2.69)\end{array}$ \\
\hline Age Repr. Gap ×\%Young Trus. $(<46)$ & & & $\begin{array}{c}-0.103^{*} \\
(-1.90)\end{array}$ & & & \\
\hline$\%$ Young Trustees $($ Age $<40)$ & & & & $\begin{array}{l}-0.047 \\
(-1.39)\end{array}$ & $\begin{array}{l}-0.026 \\
(-0.72)\end{array}$ & $\begin{array}{l}-0.001 \\
(-0.02)\end{array}$ \\
\hline Age Repr. Gap ×\%Young Trus. $(<40)$ & & & & & & $\begin{array}{c}-0.139^{*} \\
(-1.76)\end{array}$ \\
\hline Board Size & $\begin{array}{l}-0.333 \\
(-1.37)\end{array}$ & $\begin{array}{l}-0.328 \\
(-1.36)\end{array}$ & $\begin{array}{l}-0.327 \\
(-1.36)\end{array}$ & $\begin{array}{l}-0.341 \\
(-1.41)\end{array}$ & $\begin{array}{l}-0.332 \\
(-1.38)\end{array}$ & $\begin{array}{l}-0.341 \\
(-1.42)\end{array}$ \\
\hline Board Average Tenure & $\begin{array}{l}-0.020 \\
(-0.11)\end{array}$ & $\begin{array}{l}-0.032 \\
(-0.18)\end{array}$ & $\begin{array}{l}-0.026 \\
(-0.15)\end{array}$ & $\begin{array}{l}-0.010 \\
(-0.06)\end{array}$ & $\begin{array}{l}-0.030 \\
(-0.17)\end{array}$ & $\begin{array}{l}-0.019 \\
(-0.11)\end{array}$ \\
\hline$\%$ Female Trustees & $\begin{array}{l}0.041 \\
(1.37)\end{array}$ & $\begin{array}{l}0.042 \\
(1.38)\end{array}$ & $\begin{array}{l}0.041 \\
(1.35)\end{array}$ & $\begin{array}{c}0.039 \\
(1.29)\end{array}$ & $\begin{array}{l}0.041 \\
(1.35)\end{array}$ & $\begin{array}{l}0.039 \\
(1.31)\end{array}$ \\
\hline \% Employer Trustees & $\begin{array}{l}-0.042 \\
(-1.06)\end{array}$ & $\begin{array}{l}-0.038 \\
(-0.96)\end{array}$ & $\begin{array}{l}-0.039 \\
(-0.97)\end{array}$ & $\begin{array}{l}-0.042 \\
(-1.05)\end{array}$ & $\begin{array}{l}-0.037 \\
(-0.95)\end{array}$ & $\begin{array}{l}-0.037 \\
(-0.93)\end{array}$ \\
\hline \% Retirees Trustees & $\begin{array}{l}0.003 \\
(0.07)\end{array}$ & $\begin{array}{l}-0.003 \\
(-0.06)\end{array}$ & $\begin{array}{l}-0.002 \\
(-0.05)\end{array}$ & $\begin{array}{l}0.004 \\
(0.09)\end{array}$ & $\begin{array}{l}-0.003 \\
(-0.07)\end{array}$ & $\begin{array}{l}-0.005 \\
(-0.11)\end{array}$ \\
\hline$\%$ Independent Trustees & $\begin{array}{l}0.004 \\
(0.17)\end{array}$ & $\begin{array}{l}0.002 \\
(0.09)\end{array}$ & $\begin{array}{l}0.004 \\
(0.14)\end{array}$ & $\begin{array}{l}0.004 \\
(0.15)\end{array}$ & $\begin{array}{l}0.002 \\
(0.06)\end{array}$ & $\begin{array}{l}0.002 \\
(0.06)\end{array}$ \\
\hline$\%$ University Degree & $\begin{array}{l}-0.024 \\
(-0.96)\end{array}$ & $\begin{array}{l}-0.024 \\
(-0.96)\end{array}$ & $\begin{array}{l}-0.026 \\
(-1.05)\end{array}$ & $\begin{array}{l}-0.026 \\
(-1.01)\end{array}$ & $\begin{array}{l}-0.025 \\
(-0.99)\end{array}$ & $\begin{array}{l}-0.025 \\
(-1.02)\end{array}$ \\
\hline$\%$ Public Background & $\begin{array}{l}0.012 \\
(0.28)\end{array}$ & $\begin{array}{l}0.012 \\
(0.27)\end{array}$ & $\begin{array}{l}0.017 \\
(0.37)\end{array}$ & $\begin{array}{l}0.014 \\
(0.31)\end{array}$ & $\begin{array}{l}0.013 \\
(0.29)\end{array}$ & $\begin{array}{l}0.016 \\
(0.35)\end{array}$ \\
\hline$\%$ Finance Background & $\begin{array}{c}0.091^{* * *} \\
(2.75)\end{array}$ & $\begin{array}{c}0.093^{* * *} \\
(2.80)\end{array}$ & $\begin{array}{c}0.093^{* * *} \\
(2.82)\end{array}$ & $\begin{array}{c}0.088^{* * *} \\
(2.64)\end{array}$ & $\begin{array}{c}0.092^{* * *} \\
(2.75)\end{array}$ & $\begin{array}{c}0.091^{* * *} \\
(2.75)\end{array}$ \\
\hline Average Age Active Participants & $\begin{array}{c}0.309^{* *} \\
(2.30)\end{array}$ & $\begin{array}{c}0.414^{* * *} \\
(2.94)\end{array}$ & $\begin{array}{c}0.396^{* * *} \\
(2.86)\end{array}$ & $\begin{array}{c}0.313^{* *} \\
(2.33)\end{array}$ & $\begin{array}{c}0.427^{* * *} \\
(3.01)\end{array}$ & $\begin{array}{c}0.415^{* * *} \\
(2.98)\end{array}$ \\
\hline \% Retirees & $\begin{array}{l}-0.022 \\
(-0.50)\end{array}$ & $\begin{array}{l}-0.025 \\
(-0.57)\end{array}$ & $\begin{array}{l}-0.023 \\
(-0.53)\end{array}$ & $\begin{array}{l}-0.021 \\
(-0.48)\end{array}$ & $\begin{array}{l}-0.024 \\
(-0.57)\end{array}$ & $\begin{array}{l}-0.021 \\
(-0.49)\end{array}$ \\
\hline Log Size & $\begin{array}{c}-1.461^{* * *} \\
(-3.60)\end{array}$ & $\begin{array}{c}-1.451^{* * *} \\
(-3.58)\end{array}$ & $\begin{array}{c}-1.438^{* * *} \\
(-3.54)\end{array}$ & $\begin{array}{c}-1.416^{* * *} \\
(-3.42)\end{array}$ & $\begin{array}{c}-1.431^{* * *} \\
(-3.46)\end{array}$ & $\begin{array}{c}-1.423^{* * *} \\
(-3.44)\end{array}$ \\
\hline Lag Funding Ratio & $\begin{array}{c}-0.089^{* * *} \\
(-4.27)\end{array}$ & $\begin{array}{c}-0.090^{* * *} \\
(-4.32)\end{array}$ & $\begin{array}{c}-0.089^{* * *} \\
(-4.25)\end{array}$ & $\begin{array}{c}-0.090^{* * *} \\
(-4.31)\end{array}$ & $\begin{array}{c}-0.091^{* * *} \\
(-4.35)\end{array}$ & $\begin{array}{c}-0.088^{* * *} \\
(-4.29)\end{array}$ \\
\hline Swap Ratio & $\begin{array}{c}-0.041^{*} \\
(-1.85)\end{array}$ & $\begin{array}{c}-0.039^{*} \\
(-1.79)\end{array}$ & $\begin{array}{c}-0.038^{*} \\
(-1.74)\end{array}$ & $\begin{array}{c}-0.042^{*} \\
(-1.91)\end{array}$ & $\begin{array}{c}-0.040^{*} \\
(-1.81)\end{array}$ & $\begin{array}{c}-0.037^{*} \\
(-1.71)\end{array}$ \\
\hline Professional Pension Funds. & $\begin{array}{l}0.536 \\
(0.19)\end{array}$ & $\begin{array}{l}0.515 \\
(0.19)\end{array}$ & $\begin{array}{l}0.336 \\
(0.12)\end{array}$ & $\begin{array}{l}0.424 \\
(0.15)\end{array}$ & $\begin{array}{l}0.457 \\
(0.16)\end{array}$ & $\begin{array}{l}0.328 \\
(0.11)\end{array}$ \\
\hline Industry Pension Funds. & $\begin{array}{c}4.165^{* *} \\
(2.21)\end{array}$ & $\begin{array}{c}3.847^{* *} \\
(2.05)\end{array}$ & $\begin{array}{c}3.727^{* *} \\
(2.00)\end{array}$ & $\begin{array}{c}4.193^{* *} \\
(2.22)\end{array}$ & $\begin{array}{c}3.819^{* *} \\
(2.03)\end{array}$ & $\begin{array}{c}3.684^{* *} \\
(1.98)\end{array}$ \\
\hline Constant & $\begin{array}{c}82.015^{* * *} \\
(10.56) \\
\end{array}$ & $\begin{array}{c}76.522^{* * *} \\
(9.49) \\
\end{array}$ & $\begin{array}{c}76.383^{* * *} \\
(9.50) \\
\end{array}$ & $\begin{array}{c}80.981^{* * *} \\
(10.29) \\
\end{array}$ & $\begin{array}{c}75.473^{* * *} \\
(9.19) \\
\end{array}$ & $\begin{array}{c}75.222^{* * *} \\
(9.19) \\
\end{array}$ \\
\hline Time Dummies & Yes & Yes & Yes & Yes & Yes & Yes \\
\hline Observations & 2392 & 2392 & 2392 & 2392 & 2392 & 2392 \\
\hline$R^{2}$ & 0.124 & 0.126 & 0.129 & 0.122 & 0.126 & 0.129 \\
\hline
\end{tabular}

Notes: The table shows a pooled OLS in Equation 2.1): $y_{i, t}=\alpha+X_{i, t} \beta+Z_{i, t} \gamma+\theta_{t}+\epsilon_{i, t}$. The dependent variable $y_{i, t}$ is the portfolio share of fixed income for pension fund $i$ in year $t . X_{i, t}$ is the set of pension fund characteristics, $Z_{i, t}$ is the set of board characteristics, and $\theta_{t}$ is the year fixed effect. We add a control variable to columns (2) - (3) and (5) - (6), namely the age-representation gap. The age-representation gap is a dummy variable that equals one when pension funds display a difference of 10 years or more between the average age of the active participants and the average age of the board. This dummy is then interacted with the share of young trustees on the board to capture their behavior in funds with a large age-representation gap. The estimation relies on standard errors clustered at the pension fund level to correct for serial correlation. $t$ statistics in parentheses. ${ }^{*} p<0.1,{ }^{* *} p<0.05,{ }^{* * *} p<0.01$. 
Table 2.16: The effect of young trustees on the fixed income allocation in corporate pension funds

\begin{tabular}{|c|c|c|c|c|c|c|}
\hline & $(1)$ & $(2)$ & (3) & (4) & (5) & (6) \\
\hline$\%$ Young Trustees $($ Age $<46$ ) & $\begin{array}{c}-0.051^{*} \\
(-1.72)\end{array}$ & $\begin{array}{l}-0.021 \\
(-0.67)\end{array}$ & $\begin{array}{l}0.010 \\
(0.31)\end{array}$ & & & \\
\hline Age Representation Gap & & $\begin{array}{c}2.646^{* *} \\
(2.48)\end{array}$ & $\begin{array}{c}5.081^{* * *} \\
(3.60)\end{array}$ & & $\begin{array}{c}2.878^{* * *} \\
(2.70)\end{array}$ & $\begin{array}{c}4.082^{* * *} \\
(3.39)\end{array}$ \\
\hline Age Repr. Gap ×\% Young Trus. $(<46)$ & & & $\begin{array}{c}-0.191^{* * *} \\
(-2.93)\end{array}$ & & & \\
\hline \% Young Trustees $($ Age $<40$ ) & & & & $\begin{array}{l}-0.044 \\
(-1.20)\end{array}$ & $\begin{array}{l}-0.014 \\
(-0.38)\end{array}$ & $\begin{array}{l}0.014 \\
(0.36)\end{array}$ \\
\hline Age Repr. Gap ×\% Young Trus. $(<40)$ & & & & & & $\begin{array}{c}-0.213^{* *} \\
(-2.52)\end{array}$ \\
\hline Board Size & $\begin{array}{l}-0.448 \\
(-1.41)\end{array}$ & $\begin{array}{l}-0.444 \\
(-1.43)\end{array}$ & $\begin{array}{l}-0.450 \\
(-1.46)\end{array}$ & $\begin{array}{l}-0.457 \\
(-1.45)\end{array}$ & $\begin{array}{l}-0.447 \\
(-1.44)\end{array}$ & $\begin{array}{l}-0.455 \\
(-1.48)\end{array}$ \\
\hline Board Average Tenure & $\begin{array}{l}0.003 \\
(0.02)\end{array}$ & $\begin{array}{l}-0.014 \\
(-0.06)\end{array}$ & $\begin{array}{c}0.003 \\
(0.01)\end{array}$ & $\begin{array}{l}0.024 \\
(0.11)\end{array}$ & $\begin{array}{l}-0.007 \\
(-0.03)\end{array}$ & $\begin{array}{l}0.009 \\
(0.04)\end{array}$ \\
\hline$\%$ Female Trustees & $\begin{array}{l}0.037 \\
(0.86)\end{array}$ & $\begin{array}{l}0.035 \\
(0.82)\end{array}$ & $\begin{array}{l}0.034 \\
(0.78)\end{array}$ & $\begin{array}{l}0.032 \\
(0.74)\end{array}$ & $\begin{array}{l}0.033 \\
(0.77)\end{array}$ & $\begin{array}{l}0.033 \\
(0.77)\end{array}$ \\
\hline \% Employer Trustees & $\begin{array}{c}-0.103^{*} \\
(-1.87)\end{array}$ & $\begin{array}{l}-0.092^{*} \\
(-1.69)\end{array}$ & $\begin{array}{l}-0.090 \\
(-1.64)\end{array}$ & $\begin{array}{c}-0.101^{*} \\
(-1.82)\end{array}$ & $\begin{array}{c}-0.090^{*} \\
(-1.66)\end{array}$ & $\begin{array}{l}-0.087 \\
(-1.61)\end{array}$ \\
\hline$\%$ Retirees Trustees & $\begin{array}{l}-0.011 \\
(-0.20)\end{array}$ & $\begin{array}{l}-0.021 \\
(-0.40)\end{array}$ & $\begin{array}{l}-0.019 \\
(-0.38)\end{array}$ & $\begin{array}{l}-0.007 \\
(-0.13)\end{array}$ & $\begin{array}{l}-0.020 \\
(-0.39)\end{array}$ & $\begin{array}{l}-0.021 \\
(-0.42)\end{array}$ \\
\hline$\%$ Independent Trustees & $\begin{array}{l}-0.011 \\
(-0.20)\end{array}$ & $\begin{array}{l}-0.011 \\
(-0.20)\end{array}$ & $\begin{array}{l}-0.004 \\
(-0.07)\end{array}$ & $\begin{array}{l}-0.009 \\
(-0.17)\end{array}$ & $\begin{array}{l}-0.010 \\
(-0.19)\end{array}$ & $\begin{array}{l}-0.006 \\
(-0.11)\end{array}$ \\
\hline \% University Degree & $\begin{array}{l}-0.034 \\
(-1.07)\end{array}$ & $\begin{array}{l}-0.036 \\
(-1.13)\end{array}$ & $\begin{array}{l}-0.041 \\
(-1.31)\end{array}$ & $\begin{array}{l}-0.036 \\
(-1.14)\end{array}$ & $\begin{array}{l}-0.037 \\
(-1.17)\end{array}$ & $\begin{array}{l}-0.038 \\
(-1.23)\end{array}$ \\
\hline \% Public Background & $\begin{array}{l}-0.011 \\
(-0.11)\end{array}$ & $\begin{array}{l}-0.007 \\
(-0.07)\end{array}$ & $\begin{array}{l}-0.000 \\
(-0.00)\end{array}$ & $\begin{array}{l}-0.005 \\
(-0.05)\end{array}$ & $\begin{array}{l}-0.004 \\
(-0.04)\end{array}$ & $\begin{array}{l}-0.004 \\
(-0.04)\end{array}$ \\
\hline$\%$ Finance Background & $\begin{array}{c}0.117^{* * *} \\
(3.08)\end{array}$ & $\begin{array}{c}0.123^{* * *} \\
(3.25)\end{array}$ & $\begin{array}{c}0.126^{* * *} \\
(3.34)\end{array}$ & $\begin{array}{c}0.112^{* * *} \\
(2.95)\end{array}$ & $\begin{array}{c}0.122^{* * *} \\
(3.21)\end{array}$ & $\begin{array}{c}0.123^{* * *} \\
(3.24)\end{array}$ \\
\hline Average Age Active Participants & $\begin{array}{c}0.460^{* * *} \\
(2.93)\end{array}$ & $\begin{array}{c}0.634^{* * *} \\
(3.80)\end{array}$ & $\begin{array}{c}0.593^{* * *} \\
(3.64)\end{array}$ & $\begin{array}{c}0.461^{* * *} \\
(2.93)\end{array}$ & $\begin{array}{c}0.650^{* * *} \\
(3.85)\end{array}$ & $\begin{array}{c}0.619^{* * *} \\
(3.77)\end{array}$ \\
\hline$\%$ Retirees & $\begin{array}{l}-0.033 \\
(-0.80)\end{array}$ & $\begin{array}{l}-0.042 \\
(-1.05)\end{array}$ & $\begin{array}{l}-0.038 \\
(-0.97)\end{array}$ & $\begin{array}{l}-0.032 \\
(-0.78)\end{array}$ & $\begin{array}{l}-0.043 \\
(-1.06)\end{array}$ & $\begin{array}{l}-0.035 \\
(-0.89)\end{array}$ \\
\hline Log Size & $\begin{array}{c}-1.062^{* *} \\
(-2.01)\end{array}$ & $\begin{array}{l}-1.008^{*} \\
(-1.92)\end{array}$ & $\begin{array}{c}-0.952^{*} \\
(-1.81)\end{array}$ & $\begin{array}{c}-0.993^{*} \\
(-1.82)\end{array}$ & $\begin{array}{l}-0.975^{*} \\
(-1.79)\end{array}$ & $\begin{array}{c}-0.971^{*} \\
(-1.79)\end{array}$ \\
\hline Lag Funding Ratio & $\begin{array}{c}-0.107^{* * *} \\
(-6.18)\end{array}$ & $\begin{array}{c}-0.107^{* * *} \\
(-6.14)\end{array}$ & $\begin{array}{c}-0.104^{* * *} \\
(-6.22)\end{array}$ & $\begin{array}{c}-0.108^{* * *} \\
(-6.16)\end{array}$ & $\begin{array}{c}-0.108^{* * *} \\
(-6.12)\end{array}$ & $\begin{array}{c}-0.104^{* * *} \\
(-6.35)\end{array}$ \\
\hline Swap Ratio & $\begin{array}{c}-0.049^{*} \\
(-1.80)\end{array}$ & $\begin{array}{l}-0.050^{*} \\
(-1.84)\end{array}$ & $\begin{array}{c}-0.050^{*} \\
(-1.86)\end{array}$ & $\begin{array}{c}-0.051^{*} \\
(-1.85)\end{array}$ & $\begin{array}{c}-0.050^{*} \\
(-1.86)\end{array}$ & $\begin{array}{c}-0.050^{*} \\
(-1.85)\end{array}$ \\
\hline Constant & $\begin{array}{c}78.730^{* * *} \\
(8.47) \\
\end{array}$ & $\begin{array}{c}69.126^{* * *} \\
(7.09) \\
\end{array}$ & $\begin{array}{c}69.100^{* * *} \\
(7.14) \\
\end{array}$ & $\begin{array}{c}77.285^{* * *} \\
(8.06) \\
\end{array}$ & $\begin{array}{c}67.665^{* * *} \\
(6.69) \\
\end{array}$ & $\begin{array}{c}67.937^{* * *} \\
(6.77) \\
\end{array}$ \\
\hline Pension Fund Characteristics & Yes & Yes & Yes & Yes & Yes & Yes \\
\hline Time Dummies & Yes & Yes & Yes & Yes & Yes & Yes \\
\hline Observations & 1761 & 1761 & 1761 & 1761 & 1761 & 1761 \\
\hline$R^{2}$ & 0.145 & 0.151 & 0.160 & 0.142 & 0.150 & 0.156 \\
\hline
\end{tabular}

Notes: The table shows a pooled OLS in Equation 2.1: $y_{i, t}=\alpha+X_{i, t} \beta+Z_{i, t} \gamma+\theta_{t}+\epsilon_{i, t}$. The dependent variable $y_{i, t}$ is the portfolio share of fixed income for pension fund $i$ in year $t . X_{i, t}$ is the set of pension fund characteristics, $Z_{i, t}$ is the set of board characteristics, and $\theta_{t}$ is the year fixed effect. We add a control variable to columns (2) - (3) and (5) - (6), namely the age-representation gap. The age-representation gap is a dummy variable that equals one when pension funds display a difference of 10 years or more between the average age of the active participants and the average age of the board. This dummy is then interacted with the share of young trustees on the board to capture their behavior in funds with a large age-representation gap. The table displays the results for corporate pension funds. The estimation relies on standard errors clustered at the pension fund level to correct for serial correlation. $t$ statistics in parentheses. ${ }^{*} p<0.1,{ }^{* *} p<0.05,{ }^{* * *} p<0.01$. 
Table 2.17: The effect of young trustees on the fixed income allocation in non-corporate pension funds

\begin{tabular}{|c|c|c|c|c|c|c|}
\hline & $(1)$ & $(2)$ & $(3)$ & $(4)$ & $(5)$ & (6) \\
\hline$\%$ Young Trustees $($ Age $<46)$ & $\begin{array}{l}-0.041 \\
(-0.61)\end{array}$ & $\begin{array}{l}-0.029 \\
(-0.44)\end{array}$ & $\begin{array}{l}-0.056 \\
(-0.62)\end{array}$ & & & \\
\hline Age Representation Gap & & $\begin{array}{l}0.865 \\
(0.53)\end{array}$ & $\begin{array}{l}-0.035 \\
(-0.01)\end{array}$ & & $\begin{array}{l}1.088 \\
(0.62)\end{array}$ & $\begin{array}{l}0.827 \\
(0.41)\end{array}$ \\
\hline Age Repr. Gap $\times \%$ Young Trus. $(<46)$ & & & $\begin{array}{l}0.057 \\
(0.47)\end{array}$ & & & \\
\hline$\%$ Young Trustees $($ Age $<40)$ & & & & $\begin{array}{l}-0.043 \\
(-0.40)\end{array}$ & $\begin{array}{l}-0.027 \\
(-0.25)\end{array}$ & $\begin{array}{l}-0.044 \\
(-0.32)\end{array}$ \\
\hline Age Repr. Gap $\times \%$ Young Trus. $(<40)$ & & & & & & $\begin{array}{l}0.041 \\
(0.21)\end{array}$ \\
\hline Board Size & $\begin{array}{l}-0.304 \\
(-0.83)\end{array}$ & $\begin{array}{l}-0.298 \\
(-0.81)\end{array}$ & $\begin{array}{l}-0.298 \\
(-0.81)\end{array}$ & $\begin{array}{l}-0.314 \\
(-0.85)\end{array}$ & $\begin{array}{l}-0.303 \\
(-0.83)\end{array}$ & $\begin{array}{l}-0.299 \\
(-0.81)\end{array}$ \\
\hline Board Average Tenure & $\begin{array}{l}-0.176 \\
(-0.60)\end{array}$ & $\begin{array}{l}-0.186 \\
(-0.64)\end{array}$ & $\begin{array}{l}-0.180 \\
(-0.62)\end{array}$ & $\begin{array}{l}-0.170 \\
(-0.58)\end{array}$ & $\begin{array}{l}-0.184 \\
(-0.63)\end{array}$ & $\begin{array}{l}-0.184 \\
(-0.63)\end{array}$ \\
\hline$\%$ Female Trustees & $\begin{array}{l}0.050 \\
(1.08)\end{array}$ & $\begin{array}{l}0.052 \\
(1.11)\end{array}$ & $\begin{array}{l}0.050 \\
(1.09)\end{array}$ & $\begin{array}{l}0.050 \\
(1.10)\end{array}$ & $\begin{array}{l}0.052 \\
(1.14)\end{array}$ & $\begin{array}{l}0.052 \\
(1.14)\end{array}$ \\
\hline \% Employer Trustees & $\begin{array}{l}0.042 \\
(0.65)\end{array}$ & $\begin{array}{l}0.043 \\
(0.67)\end{array}$ & $\begin{array}{l}0.048 \\
(0.81)\end{array}$ & $\begin{array}{c}0.040 \\
(0.62)\end{array}$ & $\begin{array}{l}0.042 \\
(0.66)\end{array}$ & $\begin{array}{l}0.044 \\
(0.73)\end{array}$ \\
\hline$\%$ Retirees Trustees & $\begin{array}{c}0.000 \\
(0.00)\end{array}$ & $\begin{array}{l}0.000 \\
(0.01)\end{array}$ & $\begin{array}{l}0.005 \\
(0.08)\end{array}$ & $\begin{array}{l}-0.004 \\
(-0.06)\end{array}$ & $\begin{array}{l}-0.002 \\
(-0.04)\end{array}$ & $\begin{array}{l}0.001 \\
(0.02)\end{array}$ \\
\hline$\%$ Independent Trustees & $\begin{array}{l}0.021 \\
(0.55)\end{array}$ & $\begin{array}{l}0.021 \\
(0.55)\end{array}$ & $\begin{array}{l}0.022 \\
(0.60)\end{array}$ & $\begin{array}{l}0.020 \\
(0.51)\end{array}$ & $\begin{array}{l}0.020 \\
(0.52)\end{array}$ & $\begin{array}{l}0.021 \\
(0.56)\end{array}$ \\
\hline \% University Degree & $\begin{array}{l}0.025 \\
(0.62)\end{array}$ & $\begin{array}{l}0.028 \\
(0.70)\end{array}$ & $\begin{array}{l}0.027 \\
(0.66)\end{array}$ & $\begin{array}{l}0.025 \\
(0.61)\end{array}$ & $\begin{array}{l}0.029 \\
(0.71)\end{array}$ & $\begin{array}{l}0.028 \\
(0.70)\end{array}$ \\
\hline$\%$ Public Background & $\begin{array}{l}0.030 \\
(0.63)\end{array}$ & $\begin{array}{l}0.030 \\
(0.63)\end{array}$ & $\begin{array}{l}0.029 \\
(0.61)\end{array}$ & $\begin{array}{c}0.029 \\
(0.62)\end{array}$ & $\begin{array}{l}0.029 \\
(0.62)\end{array}$ & $\begin{array}{l}0.029 \\
(0.61)\end{array}$ \\
\hline$\%$ Finance Background & $\begin{array}{l}-0.010 \\
(-0.14)\end{array}$ & $\begin{array}{l}-0.014 \\
(-0.20)\end{array}$ & $\begin{array}{l}-0.014 \\
(-0.20)\end{array}$ & $\begin{array}{l}-0.012 \\
(-0.17)\end{array}$ & $\begin{array}{l}-0.017 \\
(-0.24)\end{array}$ & $\begin{array}{l}-0.017 \\
(-0.25)\end{array}$ \\
\hline Swap Ratio & $\begin{array}{l}-0.038 \\
(-1.01)\end{array}$ & $\begin{array}{l}-0.036 \\
(-0.93)\end{array}$ & $\begin{array}{l}-0.036 \\
(-0.94)\end{array}$ & $\begin{array}{l}-0.038 \\
(-1.03)\end{array}$ & $\begin{array}{l}-0.035 \\
(-0.93)\end{array}$ & $\begin{array}{l}-0.037 \\
(-0.96)\end{array}$ \\
\hline Average Age Active Participants & $\begin{array}{l}-0.056 \\
(-0.20)\end{array}$ & $\begin{array}{l}-0.014 \\
(-0.05)\end{array}$ & $\begin{array}{l}-0.021 \\
(-0.08)\end{array}$ & $\begin{array}{l}-0.037 \\
(-0.14)\end{array}$ & $\begin{array}{l}0.008 \\
(0.03)\end{array}$ & $\begin{array}{l}0.003 \\
(0.01)\end{array}$ \\
\hline$\%$ Retirees & $\begin{array}{l}0.073 \\
(0.59)\end{array}$ & $\begin{array}{l}0.076 \\
(0.61)\end{array}$ & $\begin{array}{l}0.078 \\
(0.63)\end{array}$ & $\begin{array}{l}0.068 \\
(0.56)\end{array}$ & $\begin{array}{l}0.074 \\
(0.60)\end{array}$ & $\begin{array}{l}0.076 \\
(0.61)\end{array}$ \\
\hline Log Size & $\begin{array}{c}-1.913^{* * *} \\
(-2.97)\end{array}$ & $\begin{array}{c}-1.932^{* * *} \\
(-2.98)\end{array}$ & $\begin{array}{c}-1.918^{* * *} \\
(-2.96)\end{array}$ & $\begin{array}{c}-1.873^{* * *} \\
(-2.93)\end{array}$ & $\begin{array}{c}-1.912^{* * *} \\
(-2.96)\end{array}$ & $\begin{array}{c}-1.913^{* * *} \\
(-2.95)\end{array}$ \\
\hline Lag Funding Ratio & $\begin{array}{l}-0.028 \\
(-0.58)\end{array}$ & $\begin{array}{l}-0.029 \\
(-0.61)\end{array}$ & $\begin{array}{l}-0.029 \\
(-0.62)\end{array}$ & $\begin{array}{l}-0.028 \\
(-0.60)\end{array}$ & $\begin{array}{l}-0.030 \\
(-0.63)\end{array}$ & $\begin{array}{l}-0.030 \\
(-0.64)\end{array}$ \\
\hline Professional Pension Funds. & $\begin{array}{l}-3.060 \\
(-0.93)\end{array}$ & $\begin{array}{l}-3.082 \\
(-0.94)\end{array}$ & $\begin{array}{l}-2.869 \\
(-0.92)\end{array}$ & $\begin{array}{l}-3.132 \\
(-0.97)\end{array}$ & $\begin{array}{l}-3.134 \\
(-0.97)\end{array}$ & $\begin{array}{l}-3.100 \\
(-0.98)\end{array}$ \\
\hline Constant & $\begin{array}{c}93.323^{* * *} \\
(6.26) \\
\end{array}$ & $\begin{array}{c}91.190^{* * *} \\
(6.33)\end{array}$ & $\begin{array}{c}91.673^{* * *} \\
(6.23)\end{array}$ & $\begin{array}{c}92.020^{* * *} \\
(6.32)\end{array}$ & $\begin{array}{c}89.815^{* * *} \\
(6.30) \\
\end{array}$ & $\begin{array}{c}90.179^{* * *} \\
(6.19)\end{array}$ \\
\hline Pension Fund Characteristics & Yes & Yes & Yes & Yes & Yes & Yes \\
\hline Time Dummies & Yes & Yes & Yes & Yes & Yes & Yes \\
\hline Observations & 631 & 631 & 631 & 631 & 631 & 631 \\
\hline$R^{2}$ & 0.149 & 0.149 & 0.150 & 0.147 & 0.149 & 0.149 \\
\hline
\end{tabular}

Notes: The table shows a pooled OLS in Equation 2.1): $y_{i, t}=\alpha+X_{i, t} \beta+Z_{i, t} \gamma+\theta_{t}+\epsilon_{i, t}$. The dependent variable $y_{i, t}$ is the portfolio share of fixed income for pension fund $i$ in year $t . X_{i, t}$ is the set of pension fund characteristics, $Z_{i, t}$ is the set of board characteristics, and $\theta_{t}$ is the year fixed effect. We add a control variable to columns (2) - (3) and (5) - (6), namely the age-representation gap. The age-representation gap is a dummy variable that equals one when pension funds display a difference of 10 years or more between the average age of the active participants and the average age of the board. This dummy is then interacted with the share of young trustees on the board to capture their behavior in funds with a large age-representation gap. The table displays the results for non-corporate pension funds. The estimation relies on standard errors clustered at the pension fund level to correct for serial correlation. $t$ statistics in parentheses. ${ }^{*} p<0.1,{ }^{* *} p<0.05,{ }^{* * *} p<0.01$. 
Figure 2-8. Relation equity allocation and average participants age

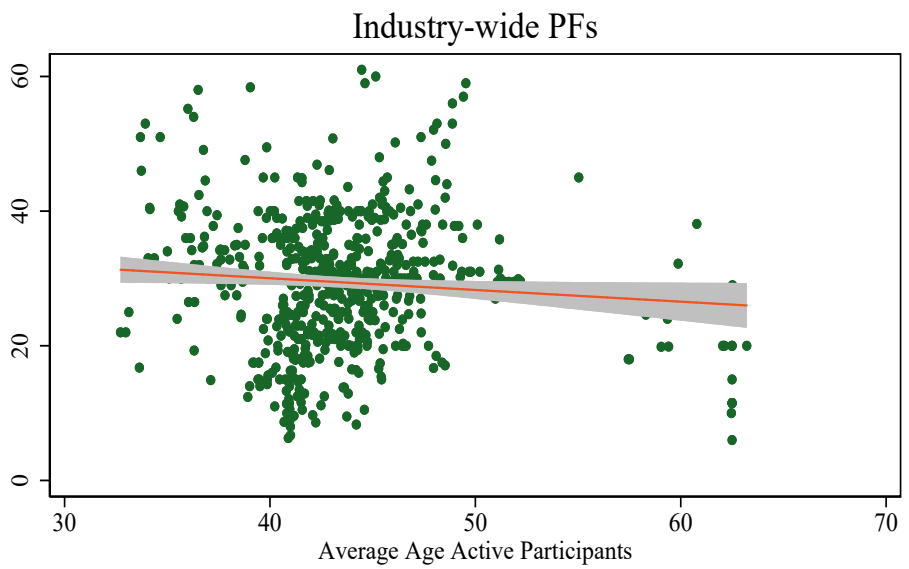

\begin{tabular}{lll|}
\hline $\begin{array}{l}\text { Equity } \\
\text { Fitted values }\end{array}$ & $95 \% \mathrm{CI}$ \\
\hline & \\
\hline
\end{tabular}

Coeff. $=-.173947 ; \mathrm{t}$-stat $=-2.09$

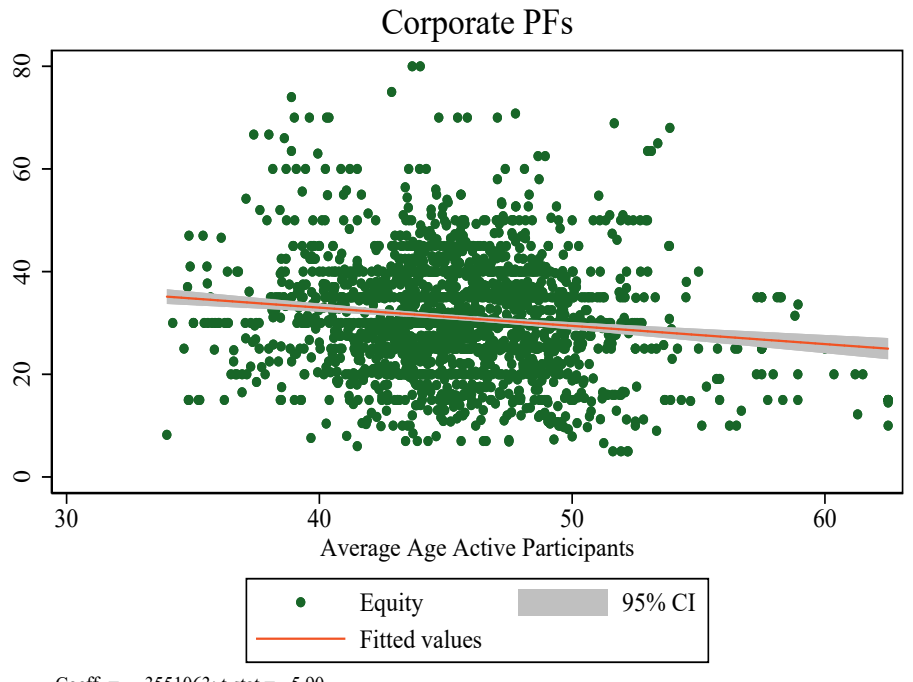

Notes: The figure shows the relation, together with the regression line, between the equity allocation and the average age of active participants for industry-wide and corporate pension funds. 


\section{Chapter 3}

\section{Common advisor effect in strategic}

\section{asset allocations*}

Pension funds are an important class of institutional investors in the economy. Assets under management in pension funds amounted to USD 42.5 trillion in 2018 in the OECD countries. Weighted according to the GDP of each OECD country, this is equivalent to an average assets-to-GDP ratio of 82.3 percent (OECD (2019)). A pension fund's assets serve to finance the future liabilities towards its beneficiaries, and a board of trustees is responsible for making investment decisions in the best interests of those beneficiaries. In preparing these investment decisions, the board of trustees typically contracts actuaries to provide support in modeling assets and liabilities and external consultants in selecting asset classes. Furthermore, the board of trustees delegates the execution of investment decisions to multiple external asset managers (van Binsbergen et al. (2008)) T These asset managers often specialize in an asset class, a geographical region, or an investment style. In several countries, pension funds may adopt a governance structure in which a single asset manager, named fiduciary asset manager, is appointed to organize the full range of advisory and

\footnotetext{
*This chapter is co-authored with Rob Bauer (Maastricht University) and Dirk Broederes (Maastricht University and De Nederlandsche Bank)

${ }^{1}$ In this paper we alternately use the terms asset managers and asset management firms. In all case we refer to the asset management firm and not an individual person.
} 
execution services on behalf of the pension fund ${ }^{2}$ Given their professional relation, fiduciary asset managers and actuaries are likely to influence trustees' decisions.

The most important investment decision to be taken by the board of trustees is the strategic asset allocation (SAA). This decision cannot be delegated and concerns the choice about the long-term mix of different asset classes, such as fixed income, equity, and real estate, in the investment portfolio. The SAA is the key determinant of the investment performance (Ibbotson and Kaplan (2000)), and therefore highly relevant for the long-term welfare of beneficiaries because even small differences in annual returns compound, over the accrual phase of multiple decades, into large differences in retirement income. Theory argues that the unique characteristics of a pension fund determine the SAA. These include the structure of its liabilities, its levels of risk-aversion and funding, its size as well as its asset class risk-return expectations and the covariance between the liability return and asset class returns (Broeders and Jansen (2020)).

We observe that pension funds with different characteristics display similarities in their SAAs. A possible explanation of these similarities is a common-advisor effect: the presence of a common advisor leads to similar decisions across pension funds with different characteristics. If a common-advisor effect exists, asset managers and actuaries are able to transfer their investment beliefs to the board of trustees that overrules a pension fund's characteristics. The common-advisor effect might therefore lead a pension fund to select a SAA that is not in line with its liability structure, funding ratio, sophistication level, or organizational structure. This asymmetry increases management costs and negatively affects performance that can lead to a welfare loss for the pension fund's beneficiaries (Andonov et al. (2018b))

Our main contribution is to show that asset managers and actuaries affect decisionmaking at the strategic level by transferring their investment beliefs to the board of trustees despite differences in pension funds' characteristics. For this endeavor,

\footnotetext{
${ }^{2}$ The "one-stop shop" fiduciary asset management model evolved in the Netherlands and in the UK in the early twenty-first century to address the increasing complexity of asset management. This complexity manifests itself in three ways: (1) an increasing range of complex asset classes such as hedge funds, private equity, and infrastructure; (2) increasing regulatory complexity; and (3) increasing (perceived) volatility in financial markets (van Nunen (2011)).
} 
we rely on a unique and proprietary database with detailed information on asset management firms, actuaries, and trustees who provide services to 191 pension funds in the Netherlands. The database is provided by the prudential supervisor of Dutch pension funds, De Nederlandsche Bank. In the Netherlands, all pension funds are required by law to periodically report their financial and governance information. To identify common advisors, we create networks of pension funds. First, we create a network of pension funds that contract the same asset manager, that is, the same asset management firm for the period from 2009 to 2016. Second, we create networks of pension funds that contract the same individual actuary for each year from 2007 to 2016. We then use spatial econometrics to test the relation between the SAAs of pension funds that are conditioned on contracting the same asset manager or the same actuary. We correct in the econometric analysis for pension fund characteristics that correlate with the SAA, in particular liability duration, funding ratio, and total assets under management. This approach captures whether asset managers and actuaries transfer their investment beliefs to the board of trustees, irrespective of pension fund characteristics.

We find a strong common-advisor effect. Pension funds that contract the same asset manager or the same actuary make similar strategic investment decisions across multiple asset classes over time, and despite significant differences in their liability structures, funding ratios, or total assets. Specifically, pension funds that contract the same asset manager adjust their SAAs in the same direction in the same year. We identify this effect in all asset classes, except for real estate. Pension funds that contract the same actuary also adjust their strategic allocations in the same direction in the same year. The common-actuary effect mainly occurs among actuaries who are involved in the asset-liability modeling. Moreover, the effect is independent from the company that an actuary works for and indicates that actuaries incorporate their private investment beliefs in their advising.

The common-advisor effect is particularly present in alternative asset classes such as private equity, hedge funds, and commodities, with spatial correlations of around 40 percent. If two pension funds increase their total strategic allocation to alternative 
asset classes by 10 percentage points in one year, then a third pension fund that contracts the same asset manager on average increases its total strategic allocation to alternatives by 2.5 percentage points, all else being equal. Alternative asset classes are often more complex, less liquid, or more risky compared to fixed income and equity. As such, alternative asset classes require decision-makers to have specific knowledge, which trustees do not necessarily possess $\mathrm{I}^{3}$ For this reason, the knowledge of asset managers and actuaries is valuable to trustees. In fact, not all pension funds are able to independently set up the right check and balances to assess the cost effectiveness of alternative asset classes (Andonov et al. (2015)). However, using this expert knowledge of alternatives may come with a cost: asset managers might have an incentive to advise assets that generate a high fee for the asset management firm. Actuaries that perform an advisory role too might have similar incentives, for example, if they work for a firm that also offers asset management services.

The similarities in investment policy cannot be explained by trustees that have a seat on multiple boards. Trustees can be appointed to multiple pension funds. Therefore, rather than measuring a common-advisor effect, we might capture the influence that overlapping trustees have on the SAAs of different pension funds. To test for this influence, we use the names of individual trustees and their tenure to create networks of pension funds that have overlapping trustees for each year from 2007 to 2016. Based on these networks, we find no evidence of an overlapping trustee effect: pension funds with overlapping trustees do not make similar investment decisions over time. This finding shows that individual trustees cannot overrule the collective decision of a board. Strikingly, pension funds with the same liability duration or funding ratio also do not make similar investment decisions over time. This finding strengthens the existence of a common-advisor effect because asset managers and actuaries do influence a board's decisions.

We run several robustness checks to ensure that similar investment decisions can in fact be associated with the common-advisor effect and not to other factors such as

\footnotetext{
${ }^{3}$ Trustees are appointed based on representation criteria (Article 100, of the Dutch Pension Act). The board of trustees needs to have sufficient investment knowledge as a group; however, not all individual trustees need to be investment experts.
} 
pension funds that follow each other over time or general trends in the popularity of asset classes. First, we show that the current SAA of a pension fund is not correlated with the SAAs in the previous year of pension funds that contract the same asset manager or the same actuary. This indicates that pension funds do not follow each other's past investment decisions. Second, similar investment decisions do not arise because of trends in the popularity of some asset classes versus others. First-difference analyses of the SAAs show positive correlations among the changes in the SAAs of pension funds that contract the same asset manager or the same actuary.

Asset managers (and actuaries) can directly influence the SAAs of pension funds even though they do not have the actual power to make decisions. This finding is related to the fact that many asset managers in the sample are appointed as a fiduciary asset manager, which means that they have a significant involvement in the design of the SAA. So far, the literature shows that consultants contribute to forming return expectations Andonov and Rauh (2019)), affecting fund flows (Jones and Martinez (2017)), and recommending commercially connected asset managers irrespective of their skills (Jaiswal (2017)). Moreover, our study shows that asset managers and actuaries transfer their investment beliefs to pension funds across multiple asset classes, while the literature on pension fund asset management primarily focuses on equities (see, e.g., Lakonishok et al. (1992a), Coggin et al., 1993, Ferson and Khang (2002), Busse et al. 2010 and Blake et al. (2013)). In the institutional investing literature, a group of institutional investors who trade in the same direction is commonly defined as herding (Lakonishok et al. (1992b), Nofsinger and Sias (1999)). Our study therefore relates to this stream of literature, as it shows similar investment decisions by measuring the cross-sectional spatial dependence of the SAAs of pension funds that contract the same asset managers or the same actuaries over time. Our method provides a channel that leads pension funds to herd that indicates pension funds invest in the same direction in response to common signals (Froot et al., 1992, Hirshleifer et al. (1994)) ! $^{4}$

\footnotetext{
${ }^{4}$ Our study is also related to the literature that investigates the impact of social networks on institutional investors and firms' decisions, see e.g. Cohen et al. (2008) and Bouwman (2011).
} 
Our contribution is supported by access to proprietary data. The literature that investigates the role of external advisors in pension fund management is scarce. Detailed information on the names of asset managers and actuaries and their contracts' length are generally kept confidential I5 Similarly, there is no publicly available database that lists the board composition of pension funds. Jenkinson et al. (2016) use survey data to describe what drives investment recommendations of consultants to pension funds. Rossi et al. (2018) exploit interconnections between consultants and asset managers to investigate the performance of equity managers. Goyal and Wahal (2008) exploit equity managers' reports to investigate the motivations that underlie the hiring and firing decisions of pension fund sponsors. Yet, the effect of external advisors is certainly not restricted to one asset class only and, as we show, they have a more direct influence on pension funds' strategic decisions such as the SAA.

The remainder of the paper is organized as follows: We describe our data, the multiple appointments of asset managers and actuaries, and the similarities in the SAAs of groups of different pension funds in Section 3.1. Section 3.2 presents our hypotheses, and Section 3.3 introduces our method. Section 3.4 presents the results. Section 3.5 covers some robustness checks, and Section 3.6 concludes.

\subsection{Data and networks}

We conduct our study in the Dutch occupational pension funds sector. In the Netherlands, occupational pension funds have a broad coverage among workers, as there is a long tradition of providing post-retirement income. There is a variety of different pension funds, some are compulsory, and others are voluntary. Pension funds can be set up for an industry sector, an occupational group, or specifically for a large company. Some $91 \%$ of the workers automatically enroll in an employer-sponsored pension fund. The vast majority of these pensions offer a defined benefit (DB). As of December 2016, Dutch occupational pension funds managed a total of EUR 1,266

\footnotetext{
${ }^{5}$ As Rossi et al. (2018) point out that in the US for example, there is no publicly available database that collects the contract relations between pension funds and consultants or asset managers.
} 
billion (USD 1,395 billion) in assets. ${ }^{6}$

\subsubsection{Data}

To test the effect of common asset managers and actuaries on the SAA, we use a balanced panel of 191 Dutch DB pension funds over the period from 2007 to 2016 . The data are proprietary and come from the prudential supervisor of pension funds, De Nederlandsche Bank (DNB). The data are free of reporting bias, as all pension funds are obliged to report quarterly statements to the DNB. We use a balanced panel to address the consolidation that the pension sector has faced over time. $7^{7}$ Pension funds that transferred assets and liabilities to an insurance company or that merged with another pension fund during the sample period are excluded from the analysis. The motivation for this exclusion is that a gradual transfer of assets to a third party can result in a non-representative SAA and mechanical portfolio comovements. Most of the pension funds that were liquidated during the sample period were small in terms of the number of beneficiaries and assets under management. Therefore, such an exclusion does not affect the coverage of our sample, because the 191 pension funds in our database report total assets that range from 89 to $94 \%$ of the total assets under management in the entire sector every year.

Pension funds report the names of the asset management firms they contract. A 2016 survey shows that more than three quarters of Dutch pension funds rely on fiduciary asset managers and this share has increased over time ${ }^{8}$ Asset managers can be hired by multiple pension funds. If multiple pension funds appoint a single asset manager with a fiduciary mandate to manage their assets, then these fiduciary asset managers can directly influence the trustees' decisions across different pension funds. Moreover, if the fiduciary asset managers are also the executor of the investment strategies of their clients, then they might have an incentive to advise asset classes

\footnotetext{
${ }^{6}$ Figures available at: https://www.dnb.nl/en/statistics

${ }^{7}$ Increasing cost effectiveness is the primary driver of this consolidation. The number of pension funds that operate in the Netherlands decreased from 1,060 in 1997 to 290 in 2016.

${ }^{8}$ For the survey see: https://pensioenpro.nl/magazine/30002114/inhaalslag-na-aanpass ing-ftk
} 
with higher fees in order to maximize their income $9^{9}$

Pension funds also report the name of the individual actuaries and the actuarial firms that they contract with. By law, each pension fund relies on the services of two actuaries: an advisory actuary and a certifying actuary. The advisory actuary advises on the level of contributions paid to the pension fund for the accrual of new pension benefits and determines the value of the liabilities 10 The advisory actuary also performs asset-liability modelling (ALM) by assessing the long-term effect of investments, contributions, and benefit policies on the funding ratio and the claims of the various stakeholders. These stakeholders are the retirees, the current and former employees, and the employer. (Blome et al. (2007), Bauer et al. (2006)). Via the ALM study, the advisory actuary advises a SAA given the structure of the liabilities. Therefore, the advisory actuary can also influence trustees' decisions; and in the case of multiple appointments, different pension funds are likely to receive similar recommendations. The certifying actuary provides an ex-post assessment of the adequacy of the SAA of a pension fund. Therefore, the certifying actuary has no direct influence on the ALM study. But the certifying actuary can compose a remark, if she believes the SAA is not in line with the prudent person principle. According to the Dutch Pension Act, the prudent person principle means that the retirement savings must be invested in such a way as to guarantee the security, quality, liquidity, and return of the portfolio as a whole. By law, the certifying actuary must be a different person from the advisory actuary. However, a certifying actuary can be the advisory actuary at another pension fund, and vice versa. Both actuaries can work for the same actuarial firm.

On a yearly basis pension funds report information on the board of trustees such as the name, gender, age, tenure, and function of each individual trustee. The data also include the stakeholder group that each trustee represents. A trustee can represent the

\footnotetext{
${ }^{9}$ Before 2016, pension funds reported the names of all asset managers. From 2016 onward, pension funds are required to communicate only the names of asset managers who handle more than $30 \%$ of total assets.

${ }^{10}$ The value of the pension liabilities is the discounted value of the accrued pension benefit obligations. Changes in this value are due to variations in market interest rates, indexation of benefits, and actuarial factors such as demographic trends. The value of pension liabilities is necessary to determine the funding ratio of the pension fund.
} 
employer, the (current or former) employees, or the retirees in the plan. Each trustee is appointed by these "social partners". Alternatively, a trustee can also be appointed by other board members without representing a specific stakeholder group. This figure is called an independent trustee, and the board generally selects this trustee to provide specific expertise that can improve its decision-making. For example, a board may highly value an independent trustee who has experience in the asset management sector.

Table 3.1: Summary statistics

\begin{tabular}{lccccc}
\hline \hline & Obs & Mean & Std. Dev. & $25^{\text {th }}$ & $75^{\text {th }}$ \\
\hline A. Pension fund governance information & & & & & \\
Asset managers & & & & & \\
Asset managers per pension fund & 1,399 & 1.79 & 1.94 & 1.00 & 2.00 \\
Contract length & 1,399 & 6.42 & 2.02 & 5.00 & 8.00 \\
Actuaries & & & & & \\
Contract length & 1,888 & 5.29 & 2.52 & 3.00 & 7.00 \\
\% Advisor & 1,888 & 48.12 & 9.65 & 50.00 & 50.00 \\
\% Certifying & 1,888 & 51.88 & 9.65 & 50.00 & 50.00 \\
Trustees & & & & \\
Board size & 1,801 & 5.97 & 2.60 & 4.00 & 8.00 \\
Average tenure board members & 1,568 & 7.76 & 3.12 & 5.56 & 9.50 \\
\% Employer representatives & 1,801 & 44.79 & 19.57 & 37.50 & 50.00 \\
\% Retirees representatives & 1,801 & 10.98 & 13.44 & 0.00 & 20.00 \\
\% Employees representatives & 1,801 & 39.89 & 20.87 & 28.57 & 50.00 \\
\% Independent (external) & 1,801 & 3.70 & 13.99 & 0.00 & 0.00 \\
\hline B. Pension funds financial information & & & & & \\
Strategic asset allocation & & & & & \\
Fixed income & 1,910 & 57.83 & 15.06 & 48.18 & 67.79 \\
Equity & 1,910 & 31.40 & 10.97 & 24.48 & 38.08 \\
Alternatives & 1,910 & 9.93 & 8.12 & 3.90 & 15.00 \\
$\quad$ Real estate & 1,910 & 6.67 & 5.93 & 1.25 & 10.00 \\
Private equity & 1,910 & 1.19 & 2.63 & 0.00 & 0.80 \\
$\quad$ Hedge funds & 1,910 & 1.19 & 2.63 & 0.00 & 0.75 \\
$\quad$ Commodities & 1,910 & 1.20 & 2.02 & 0.00 & 2.10 \\
Other investments & 1,910 & 0.77 & 3.89 & 0.00 & 0.03 \\
Cash & 1,910 & 0.07 & 4.03 & 0.00 & 0.00 \\
Pension fund characteristics & & & & & \\
Funding ratio & 1,910 & 113.60 & 24.67 & 100.70 & 117.30 \\
Liability duration & 1,910 & 18.05 & 3.87 & 15.6 & 20.10 \\
Total assets (in 1,000 EUR) & 1,910 & $4,212,385$ & $2.29 \mathrm{e}+07$ & 181,672 & $1,458,313$ \\
Log total assets & 1,910 & 13.24 & 1.74 & 12.11 & 14.19 \\
\hline \hline
\end{tabular}

Notes: Panel A presents information about asset managers, actuaries, and trustees that work for the 191 pension funds in our sample. All information on asset managers, actuaries, and trustees are expressed at the pension fund level. Panel B presents their financial information. The asset class allocations are percentages over total assets. The mean (standard deviation) are the average (standard deviation) across pension funds and over time (2007-2016) for each variable. For some of the variables, e.g., total assets, allocations to hedge funds, and private equity, the mean is outside the $25 \%$ - $75 \%$ interval. This is due to the skewness in the distribution.

Panel A of Table 3.1 provides the summary statistics of the governance information. An average pension fund employs 1.79 asset managers with an average contract length of 6.42 years. Actuaries have an average contract length of 5.29 years. The average board size is 5.97 members. The average tenure of a trustee is 7.76 years. 
On the average board, $45 \%$ of the trustees represent the employer, $39 \%$ represent the employees, $11 \%$ represent the retirees, and $4 \%$ represent independent trustees.

For supervisory purposes, pension funds report on a quarterly basis the SAA to the DNB. For the purpose of our study, we group the investments into eight asset classes, namely equity, fixed income, real estate, private equity, hedge funds, commodities, cash, and a residual class named other investments, which among others include infrastructure investments. Quarterly reports to the DNB also include financial information such as the funding ratio, liability duration, and total assets under management. Panel B of Table 3.1 provides the summary statistics of the pension funds' financial information. On average, $58 \%$ is invested in fixed income, $31 \%$ in equity, and $10 \%$ in alternative asset classes. Most of the alternatives are allocated to real estate $(6.7 \%)$, the remaining part is equally divided among private equity, hedge funds, and commodities (1.2\% each). If we only consider pension funds that actually invest in alternative asset classes, then the average allocation is almost $12 \%$ over the 10-year period that includes $8.5 \%$ in real estate, $2.8 \%$ in private equity, $4.4 \%$ in hedge funds, and $3.4 \%$ in commodities. The pension funds in the sample have on average a funding ratio of $113.6 \%$ and are relatively heterogeneous in terms of the age distribution of the beneficiaries. Pension funds in the $25^{\text {th }}$ percentile have a liability duration lower than 15.6 years, while the pension funds in the $75^{\text {th }}$ percentile have a liability duration above 20.1 years. The distribution of sizes is skewed because there are a few very large pension funds in the Netherlands.

\subsubsection{Pension funds' networks from multiple appointments}

Our prime analysis is based on common advisors. To capture the common advisors we build networks of pension funds that are connected via asset managers and actuaries. Panel A of Table 3.2 gives the dynamics in the relations between asset managers and pension funds over time. In 2009 there were 114 asset managers working for the 191 pension funds in our sample. Of these asset managers, 46 were hired by more than one

pension fund, and there were 166 pension funds whose asset managers also worked for other pension funds (pension funds can hire more than one asset manager). 


\section{Table 3.2: Common asset managers, actuaries and trustees}

\begin{tabular}{|c|c|c|c|}
\hline \multicolumn{4}{|c|}{ Panel A: Asset Managers } \\
\hline Year & $\begin{array}{l}\text { Asset managers } \\
\text { in the sample }\end{array}$ & $\begin{array}{l}\text { Asset managers with } \\
\text { multiple contracts }\end{array}$ & $\begin{array}{c}\text { Pension funds with } \\
\text { common asset managers }\end{array}$ \\
\hline 2009 & 114 & 46 & 166 \\
\hline 2010 & 107 & 44 & 165 \\
\hline 2011 & 110 & 45 & 168 \\
\hline 2012 & 97 & 46 & 173 \\
\hline 2013 & 92 & 45 & 174 \\
\hline 2014 & 66 & 33 & 162 \\
\hline 2015 & 59 & 31 & 159 \\
\hline 2016 & 46 & 27 & 158 \\
\hline \multicolumn{4}{|c|}{ Panel B: Actuaries } \\
\hline Year & $\begin{array}{c}\text { Actuaries } \\
\text { in the sample }\end{array}$ & $\begin{array}{l}\text { Actuaries with } \\
\text { multiple contract }\end{array}$ & $\begin{array}{l}\text { Pension funds with } \\
\text { common actuaries }\end{array}$ \\
\hline 2007 & 110 & 75 & 178 \\
\hline 2008 & 116 & 71 & 184 \\
\hline 2009 & 125 & 73 & 188 \\
\hline 2010 & 122 & 72 & 189 \\
\hline 2011 & 127 & 72 & 189 \\
\hline 2012 & 126 & 69 & 190 \\
\hline 2013 & 123 & 69 & 190 \\
\hline 2014 & 122 & 66 & 187 \\
\hline 2015 & 113 & 66 & 187 \\
\hline 2016 & 98 & 57 & 187 \\
\hline \multicolumn{4}{|c|}{ Panel C: Trustees } \\
\hline Year & Trustees & $\begin{array}{c}\text { Trustees with } \\
\text { multiple appoint. }\end{array}$ & $\begin{array}{c}\text { Funds with } \\
\text { overlapping trustees }\end{array}$ \\
\hline 2007 & 461 & 32 & 52 \\
\hline 2008 & 595 & 34 & 56 \\
\hline 2009 & 709 & 43 & 58 \\
\hline 2010 & 853 & 51 & 62 \\
\hline 2011 & 1,031 & 57 & 72 \\
\hline 2012 & 1,284 & 75 & 83 \\
\hline 2013 & 1,243 & 78 & 94 \\
\hline 2014 & 1,248 & 84 & 91 \\
\hline 2015 & 1,226 & 91 & 94 \\
\hline 2016 & 1,185 & 90 & 95 \\
\hline
\end{tabular}

Notes: Panel A of the table presents the number of asset managers in the sample each year, the number of asset managers working for more than one pension fund, and the number of pension funds that share at least one asset manager with another pension fund. Information about asset managers is available from 2009 through 2016. Panel $B$ presents the number of actuaries in the sample each year, the number of actuaries providing services to more than one pension fund, and the number of pension funds whose actuary is also working for at least one other pension fund. Information about actuaries is available from 2007 through 2016. Panel B does not differentiate between advisory and certifying actuaries. Panel $\mathrm{C}$ presents the number of trustees active each year, the number of trustees sitting on more than one board, and the number of pension funds with at least one board member that sits on at least one other board. The statistics in the table are computed based on asset managers, actuaries, and trustees that are contracted by at least one of the 191 pension funds in the sample.

In 2016 the number of asset managers in the sample decreased to 46 and consequently those with multiple contracts decreased to 27 . However, the number of pension funds contracting a common asset manager roughly stayed the same throughout the sample period. This finding indicates that the asset managers who exited from the sample were not those with many multiple appointments. For our analysis, we isolate the asset manager in charge of more than $30 \%$ of the total assets of a pension fund continuously over the period from 2009 to 2016 . We therefore isolate only one 
asset manager for each pension fund. By isolating the asset managers in this way, we aim to capture the fiduciary asset managers i.e., the asset managers who are directly involved in the design of the SAAs. Pension funds are required to report the names of their asset managers; however, they do not disclose whether they are fiduciaries or not. With this procedure, we are confident that we can capture the fiduciaries, as their turnover is generally lower than other asset managers ${ }^{11}$ Panel A of Figure 3-1 displays the networks of pension funds that contract the same unique asset manager over the period from 2009 to 2016. We observe six large and separate networks of pension funds that contract the same asset managers. There are also seven smaller networks with three to five pension funds sharing the same asset managers. Our analysis henceforth will be based on these groups of asset managers.

Panel B of Table 3.2 presents the dynamics of the relations between actuaries and pension funds over time. In 2007 there were 110 actuaries in our sample, 75 of them worked for more than one pension fund, and 178 pension funds contracted either the same advisory actuary or the same certifying actuary. In 2016 the number of actuaries in the sample decreased to 98 , the number of actuaries working for more than one pension fund also decreased to 57 , but the number of pension funds contracting the same actuary was 187. By means of example, Panel B of Figure 3-1 displays the networks of the 190 pension funds that contracted the same actuary in 2012. We observe that the 69 actuaries with multiple appointments connect all pension funds but one. On average the same actuary is contracted by 10 pension funds and some actuaries are contracted by up to 20 pension funds. We define two pension funds as connected if they contract the same actuary regardless of the actuary's function. Therefore, the same actuary may be an advisory actuary for one pension fund and a certifying actuary for another pension fund.

In our empirical analysis we use the fact that multiple pension funds can appoint the same trustees. Panel $\mathrm{C}$ of Table 3.2 shows the multiple appointments of trustees over time. As of 2007 there were 461 active trustees in our sample, 32 were appointed

\footnotetext{
${ }^{11}$ Some fiduciary asset managers are spin-off from a pension fund and therefore are not contracted by the pension fund, but rather a separate entity within the pension fund itself. However, these asset management firms are also contracted by other pension funds as fiduciaries.
} 


\section{Figure 3-1. Pension funds networks}

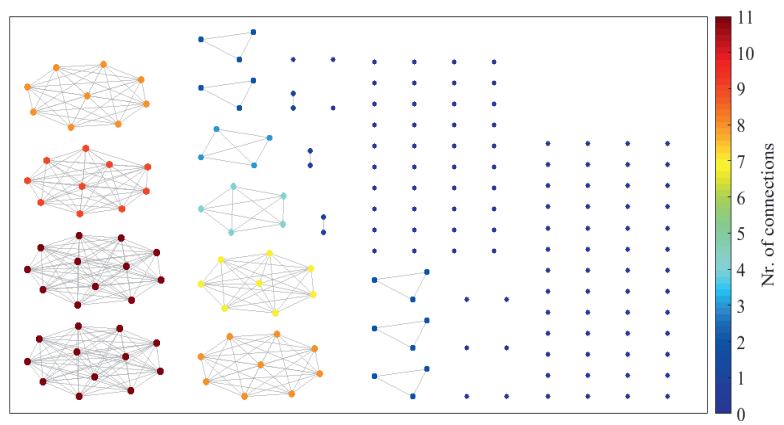

A. Unique asset managers network 2009-2016

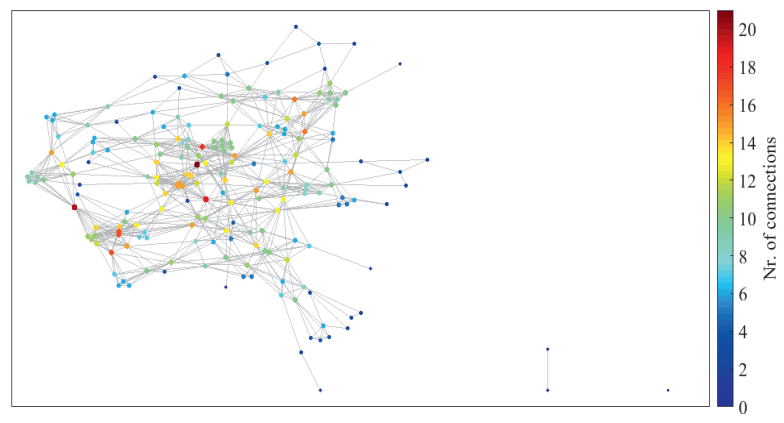

B. Actuaries network 2012

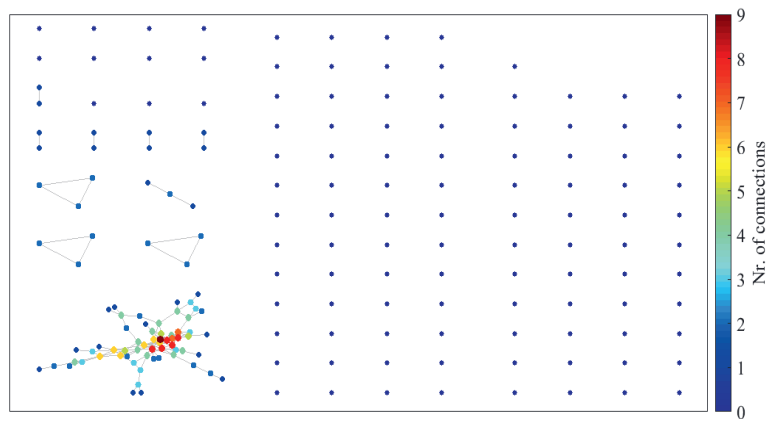

C. Trustees network 2012

Notes: Each node in the figure is a pension fund and an edge exists between two nodes, if two pension funds contract the same unique asset manager from 2009 to 2016, the same actuary, or the same trustee. The color of each nodes indicate the number of other pension funds that have the same asset manager, same actuary, or at least one overlapping trustee. 
to more than one board, and 52 pension funds had at least one trustee on their board that also sat on other pension fund boards. As of 2016 there were 1,185 active trustees in our sample, 90 were appointed to more than one board, and 95 pension funds had at least one trustee on their board that also sat on other pension fund boards. From 2007 to 2011, the number of trustees was lower than from 2012 to 2016. This is due to the different reporting system used in the first half of the sample period. We are only able to retrieve the names of trustees active between 2007 and 2011 that were still working in 2012. From 2012 onward, we have access to the entire population of trustees.

We then use the names of trustees and their tenures to create networks of pension funds that have overlapping trustees each year from 2007 to 2016. In Panel C of Figure 3-1. we show the pension funds with overlapping trustees in 2012. The number of pension funds with no overlapping trustee is high. However, there are many pension funds that have one or more trustees with multiple appointments, as on average a trustee sits on four boards. In the bottom-left-hand corner of the figure, we observe a network of 61 pension funds that originates from 66 trustees. Some of these trustees sit on as many as nine boards.

\subsubsection{Portfolio similarities and irregularities}

The objective of a pension fund is to choose an SAA that has an optimal risk-return trade-off for the assets given the structure of the liabilities and other pension fund characteristics. Therefore we expect that pension funds with a differences in liability duration, funding ratio or size to have divergent SAAs. Our quest for a commonadvisor effect starts with the observation to the contrary. In fact, if we group and compare pension funds based on some key characteristics, we see some portfolio similarities and irregularities across these groups.

First, we form quartiles of pension funds based on liability duration, funding ratio and size (measured by assets under management, AUM). Figure 3-2 shows that the average SAAs of pension funds with different liability duration and different funding levels are rather similar. Second, in Table 3.3 we show the average allocation to fixed 
Figure 3-2. Strategic asset allocation across quartiles

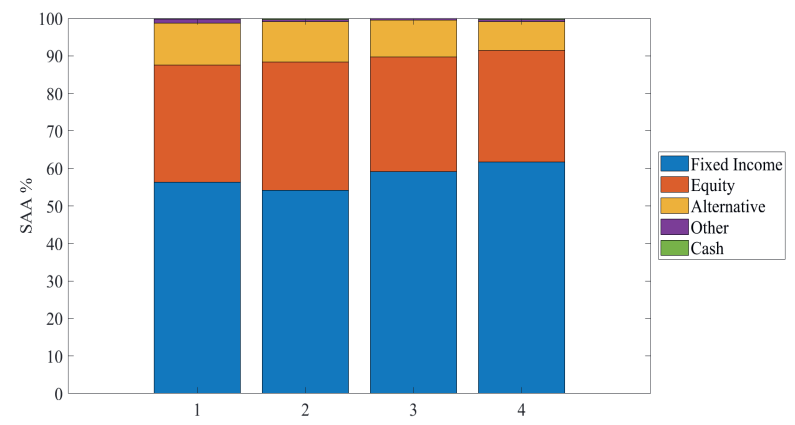

A. Average SAA by liability duration quartiles

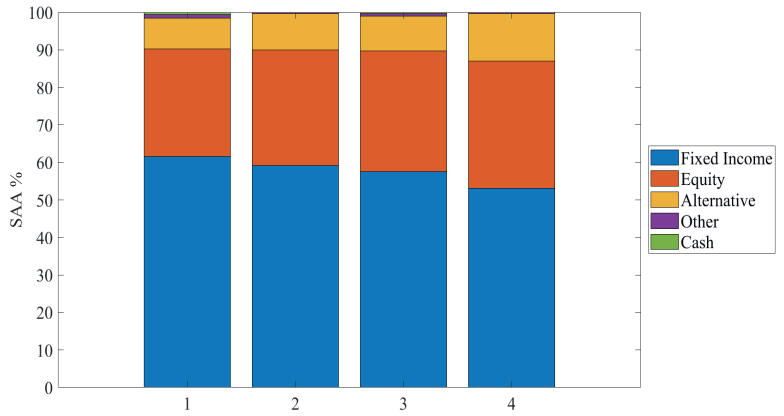

B. Average SAA by funding ratio quartiles

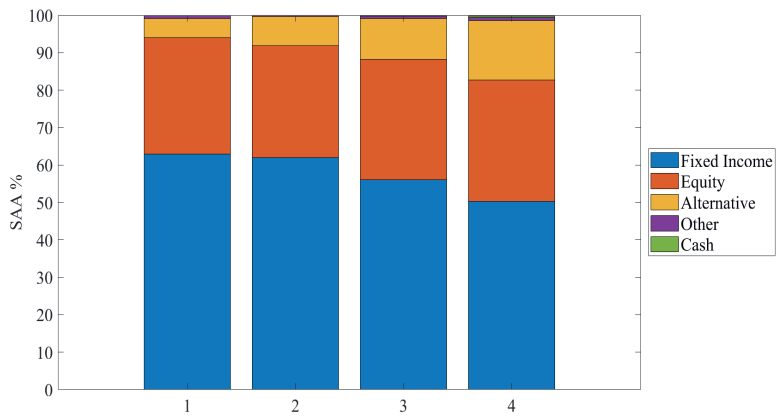

C. Average SAA by total assets quartiles

Notes: The figure shows the cross-sectional and time-series average of the SAAs across quartiles of pension funds. Quartiles are defined by time-series average liability duration (Panel A), time-series average funding ratio (Panel B), and time-series average size (Panel C). 
Table 3.3: Strategic asset allocations across quartiles

\begin{tabular}{|c|c|c|c|c|}
\hline \multicolumn{5}{|c|}{ Panel A: Liability duration } \\
\hline Quartile & Liability duration & Fixed income & Equity & Alternatives \\
\hline Q1 & 14.0 & $56.4(16.3)$ & $31.1(12.4)$ & $11.2(8.6)$ \\
\hline Q2 & 16.7 & $54.1(12.9)$ & $34.2(9.3)$ & $10.9(7.5)$ \\
\hline Q3 & 18.8 & $59.2(15.3)$ & $30.5(9.9)$ & $9.9(8.6)$ \\
\hline Q4 & 22.8 & $61.7(14.0)$ & $29.8(11.5)$ & $7.7(7.2)$ \\
\hline Q4-Q1 & & $5.3^{* * *}$ & $-1.3^{*}$ & $-3.5^{* * *}$ \\
\hline$t-s t a t$ & & $(5.37)$ & $(-1.67)$ & $(-6.80)$ \\
\hline \multicolumn{5}{|c|}{ Panel B: Funding ratio } \\
\hline Quartile & Funding ratio & Fixed income & Equity & Alternatives \\
\hline Q1 & 102.0 & $61.6(13.6)$ & $28.7(11.0)$ & $8.2(7.3)$ \\
\hline Q2 & 106.0 & $59.1(15.4)$ & $30.8(9.4)$ & $9.7(7.4)$ \\
\hline Q3 & 112.2 & $57.5(14.1)$ & $32.2(10.0)$ & $9.4(8.4)$ \\
\hline Q4 & 133.7 & $53.1(15.8)$ & $34.0(12.6)$ & $12.6(8.7)$ \\
\hline Q4-Q1 & & $-8.5^{* * *}$ & $5.3^{* * *}$ & $4.4^{* * *}$ \\
\hline$t-s t a t$ & & $(-8.87)$ & $(6.89)$ & $(8.43)$ \\
\hline \multicolumn{5}{|c|}{ Panel C: AUM (in million EUR) } \\
\hline Quartile & $\overline{\mathrm{AUM}}$ & Fixed income & Equity & Alternatives \\
\hline Q1 & 105.1 & $62.9(16.9)$ & $31.1(12.7)$ & $5.1(6.0)$ \\
\hline Q2 & 335.8 & $62.0(14.0)$ & $29.9(10.8)$ & $7.8(6.7)$ \\
\hline Q3 & 888.4 & $56.1(13.0)$ & $32.2(9.9)$ & $10.9(7.0)$ \\
\hline Q4 & $15,760.9$ & $50.3(12.4)$ & $32.4(10.2)$ & $16.0(8.4)$ \\
\hline Q4-Q1 & & $-12.6^{* * *}$ & $1.3^{*}$ & $10.9^{* * *}$ \\
\hline$t-s t a t$ & & $(-13.11)$ & $(1.74)$ & $(22.95)$ \\
\hline
\end{tabular}

Notes: This table shows the cross-sectional and time-series average of the SAAs across quartiles of pension funds. Quartiles are defined by liability duration (Panel A), funding ratio (Panel B), and size as measured by the assets under management in million EUR (AUM) (Panel C). Standard deviation across pension funds and time is given between brackets. In $Q 4-Q 1$ we present the difference in the SAAs of pension funds in the fourth and first quartile. The t-statistics are in parentheses, and * indicates statistical significance at the $10 \%$ level, ${ }^{* *}$ at the $\% 5$ level, and $* * *$ at the $1 \%$ level.

income, equity and alternatives for each quartile of liability duration, funding ratio and size. Next we perform a t-test on the difference between the mean of the first and fourth quartiles. Based on this table and test, we make the following observations.

Panel A of Table 3.3 show the average SAAs of pension funds by quartiles of liability duration. Liability duration summarizes the age distribution of the beneficiaries. It is a measure of the weighted average investment horizon across beneficiaries and therefore affects the SAA. Pension funds in the first and fourth quartiles have an average liability duration of 14.0 years and 22.8 years respectively. We observe that the average pension fund in the first quartile invests $56.4 \%$ in fixed income compared to $61.7 \%$ for the average pension fund in the fourth quartile. But the standard life-cycle theory predicts a higher allocation to fixed income for pension funds with shorter liability durations $\sqrt{12}$ Furthermore, the average pension fund in the first quar-

\footnotetext{
${ }^{12}$ Life-cycle theory incorporates human capital in the optimal asset allocation, see, e.g., Bodie et al. (1992). A high liability duration is an approximation of high human capital which can be interpreted as a high allocation to bonds under the assumption that human capital has low risk.
} 
tile invests $11.2 \%$ of its portfolio in alternatives. But the average pension fund in the fourth quartile invests $7.7 \%$. Economic reasoning argues that pension funds with a long investment horizon can invest more in illiquid assets classes ${ }^{13}$

Panel B of Table 3.3 show the average SAAs of pension funds by quartiles based on their funding ratio. Pension funds with a high funding ratio can take more investment risk. Pension funds in the first and fourth quartiles have an average funding ratio of $102.0 \%$ and $133.7 \%$ respectively. The average pension fund in the first quartile indeed invests more in fixed income and less in equity and alternatives. The average pension fund in the fourth quartile does the opposite. These differences are in line with standard economic reasoning. However, pension funds within the same quartile show a high standard deviation. This deviation indicates that differences among pension funds within the same quartile appear to be larger than the differences across pension funds of different quartiles. Comparable numbers are observed in Panel A of Table 3.3.

Panel C of Table 3.3 show the average SAAs of pension funds by quartiles based on their assets under management. Pension funds in the first and fourth quartiles have average assets under management of EUR 105.1 million and EUR 15,760.9 million, respectively. The average pension fund in the fourth quartile allocates substantially less $(12.6 \%)$ to fixed income and slightly more $(1.3 \%)$ to equity than the average pension fund in the first quartile. Moreover, large pension funds in the fourth quartile allocate significantly more $(10.9 \%)$ to alternative asset classes compared to small pension funds in the first quartile. This allocation indicates that large pension funds can exploit economies of scale in more sophisticated asset classes (Broeders et al. $(2016 \mathrm{~b}))$. However, based on the high standard deviation there are also some small pension funds that invest strongly in alternative asset classes.

\footnotetext{
${ }^{13}$ Next to a common-advisor effect, another explanation for the low allocation to alternative asset classes in the fourth quartile is that pension funds with a high liability duration need to have sufficient liquid assets available for collateral purposes in transactions that hedge interest rate risk in interest rate swaps, see Broeders et al. (2020).
} 


\subsection{Hypotheses}

We test four hypotheses to explain the similarities among SAAs. The first hypothesis concerns the common-advisor effect. A so called, common-advisor effect can explain the similarities among SAAs. As many pension funds contract the same asset manager or the same actuary, these external advisors might provide the same advice to their clients about the asset allocation, irrespective of pension fund characteristics.

In the second hypothesis we focus on the type of actuaries. The advisory actuary and the certifying actuary have separate roles to play at different stages of decisionmaking. The advisory actuary is ex ante involved through their consulting activity and via the ALM study. The certifying actuary, by contrast, is only involved ex post in verifying that the investment policy is in line with the prudent person principle. As a consequence, we predict that the influence of advisory actuaries on the similarities among SAAs is larger compared to certifying actuaries.

In the third hypothesis we turn to the trustees. The similarities among SAAs might be caused by an overlapping-trustee effect. As trustees can be appointed to more than one pension fund, they might make similar investment decisions for all pension funds to which they are appointed.

In the fourth hypothesis we explain the similarities among SAAs from similar pension fund characteristics. Pension funds with a comparable liability structure have a comparable investment horizon and cash flow needs. Therefore, these pension funds should have similar SAAs. Similarly, pension funds with comparable funding ratios face comparable funding constraints and therefore are also expected to make similar investment decisions over time. Further, pension funds of comparable size have a comparable organizational structure and sophistication level and therefore should make similar investment decisions too. 


\subsection{Methodology}

We rely on spatial econometrics to test our hypotheses. Spatial econometrics measure the spatial dependence that arises when the values of a variable observed in one location depend on the values of the same variable observed in nearby locations (LeSage and Pace (2009)). Spatial dependence is a measure of correlation. We apply the concept of neighboring regions to pension funds. In our context, proximity is not given by geographical distance but by common asset managers or by common actuaries. Therefore, we argue that in our data generating process (DGP) the values observed in one pension fund depend on the values observed in other pension funds that contract the same asset managers or the same actuaries, that is, pension funds in the same network ${ }^{14}$ We first discuss the general specification of the spatial autoregressive model and then discuss the spatial panel specification that we use.

\subsubsection{Spatial autoregressive model and weighting matrix}

The spatial autoregressive model is defined as follows:

$$
y_{i}=\rho \sum_{j=1}^{n} W_{i j} y_{j}+\epsilon_{i}
$$

where $\sum_{j=1}^{n} W_{i j} y_{j}$ is the spatial lag that represents the linear combination of the values of variable $y$ observed in neighboring pension funds. In our model $y$ is the strategic allocation of a pension fund to a given asset class. The linear combination is defined by the $n \times n$ spatial weight matrix W. Each element $w_{i j}$ in the weighting matrix $W$ equals one when pension fund $i$ and pension fund $j$ contract the same asset manager, the same actuary, or have the same trustee. The weighting matrices are standardized by row throughout the entire analysis. This standardization means that the elements of each row of $W$ are scaled to sum to unity. Standardizing over rows

\footnotetext{
${ }^{14}$ We are not the first ones to use spatial econometrics outside the domain of economic geography, see, e.g., Beck et al. (2006), Broeders et al. (2016a), Dow et al. (1984), and Simmons and Elkins (2004).
} 
means that each individual neighboring observation has a weight that is proportional to one over the total number of neighboring observations.

Our weighting matrix faces two potential complications: network dynamics and endogeneity. The first potential complication is network dynamics. In the context of geographical proximity, borders among regions are rather stable over time (see, e.g., Mukherjee and Singer (2008) and LeSage et al. (2011)). In our context, by contrast, asset managers and actuaries are replaced over time. Therefore, over our 10-year sample period we have 10 different weighting matrices for each network. However, as shown in Table 3.1, contract changes are not that frequent in practice. The average contract length of asset managers is almost six and a half years, and actuaries' average contract length is more than five years. In addition, SAAs are revised only every three to five years, and it takes time for a pension fund to implement these changes. Once a new SAA is decided, the next period portfolio will not immediately reflect that change. Consider for example a large pension fund, a change in the SAA might signal the market and therefore affect prices. For this reason, large pension funds only adjust their portfolios gradually. Furthermore, decisions such as investing or divesting in alternative asset classes takes time to implement due to a lack of liquidity and lock-up periods. It is not unusual to see the actual investment decisions being fully implemented months or, in some cases, even years after the board of trustees approves them.

After these considerations, we determine the weighting matrix in year $t$, and we then test the effect of common asset managers and common actuaries on the SAAs in the years $t, \ldots, t+4$. Ergo, we keep the weighting matrix constant for five years. The underlying assumption is that the decisions made in a given year will be implemented throughout the subsequent five years.

The second potential complication is endogeneity. Our aim is to use the commonadvisor effect as an explanatory variable for the investment decisions. However, a pension fund's investment intentions may have already affected the decision of hiring a specific asset manager. In that case the causality runs in the opposite direction. To address this endogeneity issue, we restrict the analysis to the group of unique asset 
managers defined in Section 3.1.2. We define this type of asset manager as being employed by a pension fund throughout the entire sample period and managing more than $30 \%$ of a pension fund's portfolio. We therefore isolate only one asset manager per pension fund. Since this asset manager is employed continuously over time and is responsible for a sizable share of the portfolio, they can have a significant effect on the SAA of the pension fund $\sqrt{15}$ The weighting matrix defined by the unique asset manager is by construction constant over time and consequently no new asset managers are included. Nevertheless, some pension funds could have just hired some of these asset managers at the beginning of our sample period as a reflection of presample investment intentions. In this case endogeneity could still affect our results. To be more conservative we therefore test the common-advisor effect only on the subperiod of 2012 - 2016. By doing so we are confident in saying that multiple contracts of asset managers are exogenous to any prior investment intentions.

Endogeneity is less of a concern for pension funds that contract the same actuary. Pension funds hire actuarial firms without ex ante knowing the individual actuary who will prepare the ALM study. Actuaries' main activity is not to provide a recommendation about individual investments but rather to design a set of SAAs that match the liabilities and present them to the board of trustees. In addition, the private investment beliefs of an actuary are the same regardless of the company they work for. Therefore, actuaries do not per se carry investment beliefs that belong to their firms. Precisely for this reason, we analyze the interconnections based on individual actuaries rather than at the actuarial company level.

\subsubsection{Common-advisor effect, a spatial panel approach}

As common advisors are observed for multiple pension funds over time, we rely on the following spatial panel autoregressive model (SAR) to test our hypotheses:

\footnotetext{
${ }^{15}$ We crosschecked the list of managers that results from this approach with a survey of pension funds and fiduciaries published by PensioenPro in 2013. 25\% of the pension funds in our sample declare in the PensioenPro survey to rely on the services of a fiduciary which is the same asset manager that we identify with our method. See survey at: https://pensioenpro.nl/nieuws/30 002843/overzicht-fiduciair-managers-vermogensbeheerders-selectie-obv-jaarverslagen $-2013$
} 


$$
\mathbf{y}_{t}=\rho \mathbf{W y}_{t}+\mathbf{X}_{t} \beta+\boldsymbol{\mu}+\boldsymbol{\theta}_{t}+\boldsymbol{\epsilon}_{t}
$$

where $\mathbf{y}_{t}$ is a vector that contains the strategic allocation in a given asset class of all 191 pension funds in year $t . \mathbf{X}_{t}$ is a matrix that contains pension fund characteristics that can explain the differences in the SAAs such as the funding ratio, liability duration, and size ( $\log$ of total assets under management). Further, $\boldsymbol{\mu}$ and $\boldsymbol{\theta}_{t}$ are pension fund and year fixed effects. We include these fixed effects because we are interested in measuring how the SAA of a pension fund evolves over time as a function of the SAAs of the pension funds that contract the same asset managers or the same actuaries ${ }^{16}$

The spatial correlation coefficient $\rho$ measures the direction and the magnitude of the relation between the SAAs of pension funds that contract the same asset managers or the same actuaries. A positive and statistically significant $\rho$ indicates a commonadvisor effect. This rho means that pension funds with the same asset manager or the same actuary increase or decrease the strategic allocation in a given asset class in the same year.

\subsection{Results}

In this section, we test our four hypotheses. We first show the results of the SAR model that tests if common asset managers or common actuaries influence the investment decisions of pension funds. Second, we test the common-advisor effect for advisory actuaries and certifying actuaries separately. Third, we test the existence of an overlapping-trustee effect on SAAs. Namely, we assess if individual trustees make similar strategic investment decisions if they are appointed to multiple pension funds. Fourth, we analyze if pension funds with similar liability durations, similar funding ratios, or similar sizes make similar investment decisions over time.

\footnotetext{
${ }^{16}$ See Elhorst (2013) for an excellent overview on spatial panel models.
} 
Table 3.4: Common-asset manager effect on SAAs

\begin{tabular}{|c|c|c|c|c|c|c|c|}
\hline & \multicolumn{6}{|c|}{ Common-asset manager effect on SAA - 2012-2016 } & \multirow[b]{2}{*}{$\begin{array}{c}\text { Fixed } \\
\text { income }\end{array}$} \\
\hline & Alternatives & Commodities & $\begin{array}{l}\text { Private } \\
\text { equity }\end{array}$ & $\begin{array}{l}\text { Hedge } \\
\text { funds }\end{array}$ & $\begin{array}{l}\text { Real } \\
\text { estate }\end{array}$ & Equity & \\
\hline$\rho$ & $\begin{array}{c}0.2463^{* * *} \\
(2.73)\end{array}$ & $\begin{array}{c}0.3599^{* * *} \\
\quad(4.47)\end{array}$ & $\begin{array}{c}0.4064^{* * *} \\
(4.68)\end{array}$ & $\begin{array}{c}0.4316^{* * *} \\
\quad(5.17)\end{array}$ & $\begin{array}{c}0.1293 \\
(1.44)\end{array}$ & $\begin{array}{c}0.3006^{* * *} \\
(4.91)\end{array}$ & $\begin{array}{c}0.3911^{* * *} \\
(4.72)\end{array}$ \\
\hline Duration & $\begin{array}{c}-0.0635 \\
(-0.33)\end{array}$ & $\begin{array}{l}0.0643 \\
(0.63)\end{array}$ & $\begin{array}{c}-0.0236 \\
(-0.45)\end{array}$ & $\begin{array}{c}-0.0176 \\
(-0.24)\end{array}$ & $\begin{array}{c}-0.0750 \\
(-0.57)\end{array}$ & $\begin{array}{c}0.2962 \\
(0.55)\end{array}$ & $\begin{array}{l}0.6171 \\
(0.71)\end{array}$ \\
\hline Funding ratio & $\begin{array}{c}-0.0305^{* * *} \\
(-3.07)\end{array}$ & $\begin{array}{l}-0.0051 \\
(-1.27)\end{array}$ & $\begin{array}{c}-0.0008 \\
(-0.26)\end{array}$ & $\begin{array}{c}-0.0099^{*} \\
(-1.82)\end{array}$ & $\begin{array}{c}-0.0141 \\
(-1.35)\end{array}$ & $\begin{array}{c}-0.0754 \\
(-1.21)\end{array}$ & $\begin{array}{l}0.0612 \\
(0.82)\end{array}$ \\
\hline Log size & $\begin{array}{l}0.3354 \\
(1.47) \\
\end{array}$ & $\begin{array}{l}0.2001 \\
(1.41) \\
\end{array}$ & $\begin{array}{r}-0.0136 \\
(-0.24) \\
\end{array}$ & $\begin{array}{l}0.0362 \\
(0.76) \\
\end{array}$ & $\begin{array}{l}0.1198 \\
(0.62) \\
\end{array}$ & $\begin{array}{l}0.7477 \\
(1.35) \\
\end{array}$ & $\begin{array}{l}0.6107 \\
(0.36) \\
\end{array}$ \\
\hline Year FE & YES & YES & YES & YES & YES & YES & YES \\
\hline Pension fund FE & YES & YES & YES & YES & YES & YES & YES \\
\hline$N$ & 955 & 955 & 955 & 955 & 955 & 955 & 955 \\
\hline$R^{2}$ & 0.1332 & 0.0210 & 0.0005 & 0.0038 & 0.0769 & 0.0075 & 0.0093 \\
\hline
\end{tabular}

Notes: The table shows the estimation results of Equation 3.2 namely the spatial panel autoregressive model $\mathbf{y}_{t}=$ $\rho \mathbf{W y}_{t}+\mathbf{X}_{t} \beta+\boldsymbol{\mu}+\boldsymbol{\theta}_{t}+\boldsymbol{\epsilon}_{t}$ for pension funds that contract the same asset manager. The identification of the common asset manager is defined in Section 3.3.1 The dependent variable $\mathbf{y}_{t}$ is the strategic allocation to each asset class of each pension fund in year $t$. The $\rho$ is the coefficient that describes the spatial correlation among the strategic portfolio weights of pension funds that contract the same asset manager. $\mathbf{W}$ is the weighting matrix that equals one when two pension funds contract the same asset manager and zero otherwise, and it is constant by construction. $\mathbf{X}_{t}$ is a set of control variables: funding ratio, size, and liability duration of each pension fund. And, $\boldsymbol{\mu}$ and $\boldsymbol{\theta}_{t}$ indicate fund and year fixed effects. The model is estimated on the subsample 2012-2016 to avoid reverse causality, as the contracts between pension funds and asset managers that define $\mathbf{W}$ exist prior to 2012. A positive and significant $\rho$ means that pension funds contracting the same asset manager have strategic allocations that move in the same direction over time. We estimate the models for each asset class separately and report the corresponding spatial coefficients and controls. The t-statistics are in parentheses. The ${ }^{*}$ indicates statistical significance at the $10 \%$ level, ${ }^{* *}$ at the $\% 5$ level, and ${ }^{* * *}$ at the $1 \%$ level.

\subsubsection{Common-advisor effect on the SAAs}

Our first hypothesis is that common advisors lead to similarities among SAAs. We begin by estimating the common-asset-manager effect on the SAAs. As described in Section 3.3.1. we perform this test on the subsample of 2012-2016 to avoid endogeneity concerns. Table 3.4 summarizes the estimation results of the SAR model in Equation (3.2). The results indicate a strong common-asset-manager effect in all asset classes, except real estate. The $\rho$ coefficient is 0.2463 in the first column and its interpretation is as follows: If two pension funds increase their total strategic allocation to alternative asset classes by 10 percentage points in one year, then a third pension fund that contracts the same asset manager will increase its total strategic allocation to alternatives by 2.5 percentage points, all else being equal ${ }^{17}$ We find a similar spatial correlation across individual alternative asset classes, $\rho$ equals 0.3599 in commodities, 0.4064 in private equity, and equals 0.4316 in hedge funds. Common

\footnotetext{
${ }^{17}$ For more details on the calculation of this effect we refer to Section $3 . \mathrm{A}$
} 
asset managers also have a comparable effect on the strategic allocation to equity ( $\rho=0.3006)$ and fixed income $(\rho=0.3911)$. The only exception is real estate in which we find no evidence of a common-asset-manager effect. This exception may be because the direct investments in real estate are rather fixed and cannot be easily increased or decreased. The first column in Table 3.4 also shows that as the funding ratio decreases, pension funds allocate less to alternative asset classes. This is in line with pension funds not gambling for resurrection by increasing their exposure to high-risk assets in the event of poor funding conditions.

Next, we analyze the common-actuary effect. We estimate Equation (3.2) that relies on the weighting matrices that originate from the contracts between actuaries and pension funds in 2007, 2008, 2009, 2010, 2011, and 2012. Each year, and for each asset class, we estimate the common-actuary effect on the subsequent five years. For example, we build the weighting matrix from common actuaries in 2007 . We then test the effect of these common actuaries on the SAAs over the period from 2007 to 2011. We repeat this analysis for each year until 2012 when the common actuaries began. Rather than producing extensive tables, we give a graphical representation of the results. In Figure 3-3, we plot the $\rho$ coefficients and their confidence intervals for the regressions run with each weighting matrix for alternatives, public equity, and fixed income. Panel A shows a significant common-actuary effect in alternative asset classes over time. Each year the $\rho$ coefficient is positive and significant with the exception of 2009. These coefficients indicate that common actuaries lead pension funds to positively correlated strategic allocations with alternatives over the subsequent five years. In other words, common actuaries lead to portfolio comovements in alternatives. Conversely, Panels B and $\mathrm{C}$ show that pension funds with the same actuary do not change their strategic allocations to equity and fixed income in the same direction over time.

It is reasonable to find stronger evidence of a common-actuary effect in alternatives as opposed to standard asset classes. Alternative asset classes are often more complex, less liquid, and riskier investments than public equity and fixed income. As such, they require that decision-makers have specific knowledge, which trustees do not 


\section{Figure 3-3. Common-actuary effect on SAAs}

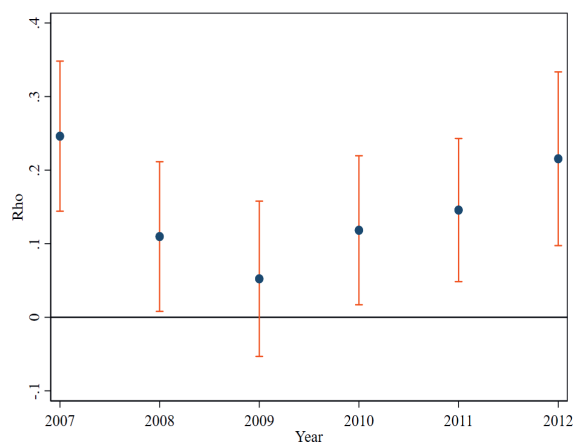

A. Alternatives

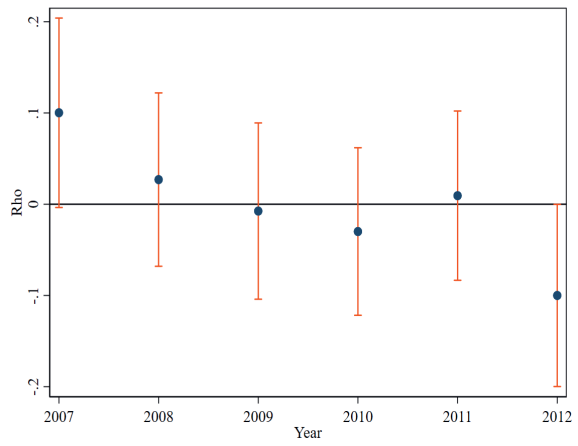

B. Equity

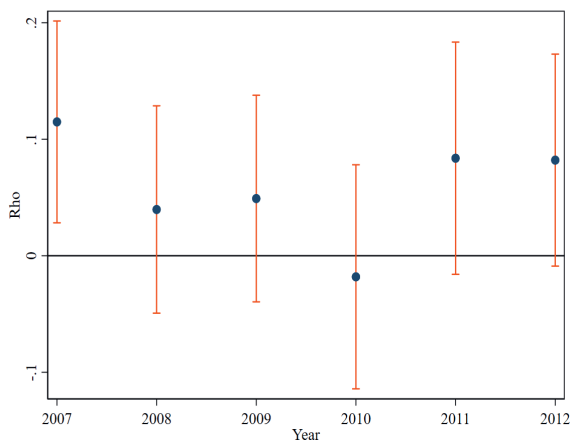

C. Fixed income

Notes: The figure displays the estimated rho coefficients with the corresponding $90 \%$ confidence interval from Equation 3.2): $\mathbf{y}_{t}=\rho \mathbf{W y}_{t}+\mathbf{X}_{t} \beta+\boldsymbol{\mu}+\boldsymbol{\theta}_{t}+\boldsymbol{\epsilon}_{t}$. The model is estimated every year over the period 2007-2012 on the subsequent five years. Every year, we use the weighting matrix built on pension funds with the same actuaries. In panel A the dependent variable is the strategic allocation to alternative assets of each pension fund, in Panel B the dependent variable is the strategic allocation to equity, and in Panel $\mathrm{C}$ the dependent variable is the strategic allocation to fixed income. 


\section{Figure 3-4. Common-actuary effect on alternative assets}
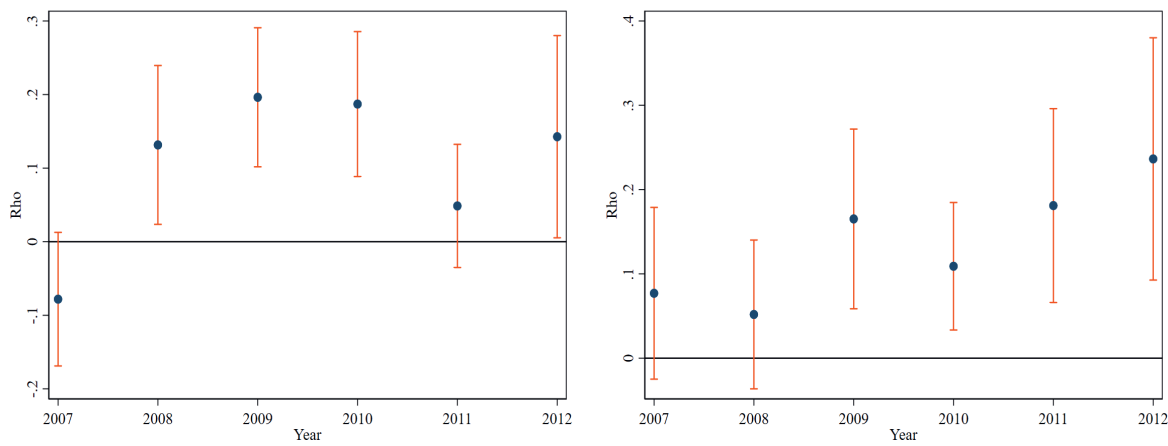

A. Private equity

B. Real estate
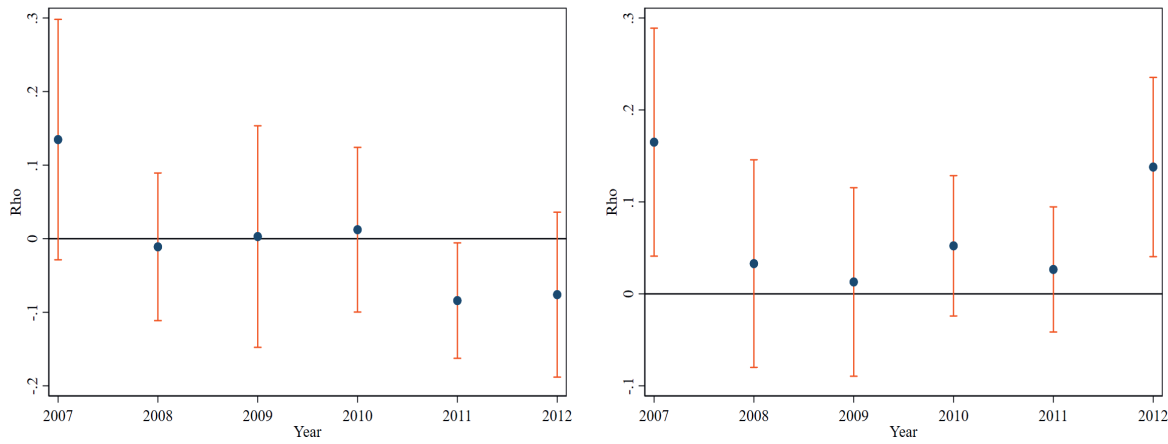

C. Hedge funds

D. Commodities

Notes: The figure displays the estimated rho coefficients with the corresponding $90 \%$ confidence interval from Equation (3.2): $\mathbf{y}_{t}=\rho \mathbf{W y}_{t}+\mathbf{X}_{t} \beta+\boldsymbol{\mu}+\boldsymbol{\theta}_{t}+\boldsymbol{\epsilon}_{t}$. The model is estimated every year over the period 2007-2012 on the subsequent five years. Every year, we use the weighting matrix built on pension funds with the same actuaries. In panel A the dependent variable is the strategic allocation to private equity of each pension fund, in Panel B the dependent variable is the strategic allocation to real estate, in Panel $\mathrm{C}$ the dependent variable is the strategic allocation to hedge funds, and in Panel D the dependent variables if the strategic allocation to commodities.

necessarily possess $($ Binfare et al. (2018)). For this reason, the opinions of specialized consultants such as actuaries are highly valuable and influential.

Figure 3-4 displays the analysis of the common-actuary effect on the allocation to different types of alternative asset classes. The results are mixed and not as conclusive as for the aggregate alternatives portfolio (Figure 3-3. Panel A). We find a common-actuary effect in private equity and real estate, while we find no evidence of a common-actuary effect in hedge funds and commodities. Therefore, actuaries are able to transfer their individual investment beliefs to their clients, but this transfer 
is stronger in the aggregate allocation to alternatives than in some individual asset classes.

To summarize, our results indicate that a common-advisor effect exists. Pension funds that contract the same asset manager increase or decrease their strategic allocations to both alternative and standard asset classes in the same year. Pension funds that contract the same actuary also increase or decrease their strategic allocations to alternatives in the same year. Factors other than pension fund characteristics should not affect the SAAs of pension funds. Therefore, finding a positive correlation among the SAAs of pension funds with the same asset managers or actuaries indicates that these advisors transfer their investment beliefs to their clients, irrespective of pension fund characteristics.

\subsubsection{Disentangling the common-actuary effect}

Our second hypothesis is that common advisory actuaries lead to similarities among SAAs. In the previous section we saw that pension funds with the same actuary make similar investment decisions for alternative asset classes. We find this similarity when pension funds contract with either the same advisory or the same certifying actuary. Yet, the advisory actuary and the certifying actuary have distinctly separate roles. The advisory actuary can affect a pension fund's investment decisions ex ante. Conversely, the certifying actuary can only ex post reflect on a pension fund's investment decisions. In order to disentangle the effect of each type of actuary on the investment decisions, we estimate Equation 3.2 separately for pension funds with the same advisory actuary and for pension funds with the same certifying actuary. By doing so we reduce the number of multiple contracts for each actuary. On average, an advisory actuary has contracts with four pension funds. Similarly, a certifying actuary has contracts with on average four pension funds.

In line with our hypothesis, we find a strong common-actuary effect when limiting the analysis to the pension funds that contract the same advisory actuary. Differently, we find limited evidence of a common-actuary effect when limiting the analysis to the pension funds that contract the same certifying actuary. Panel A of Figure 3-5] dis- 
Figure 3-5. Common type of actuary or common actuarial firm

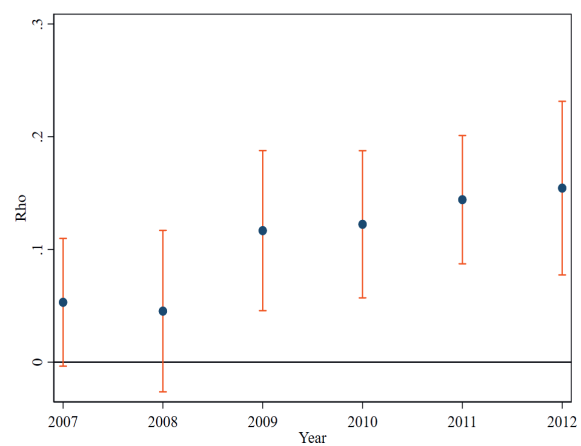

A. Alternatives - Common advisory actuary

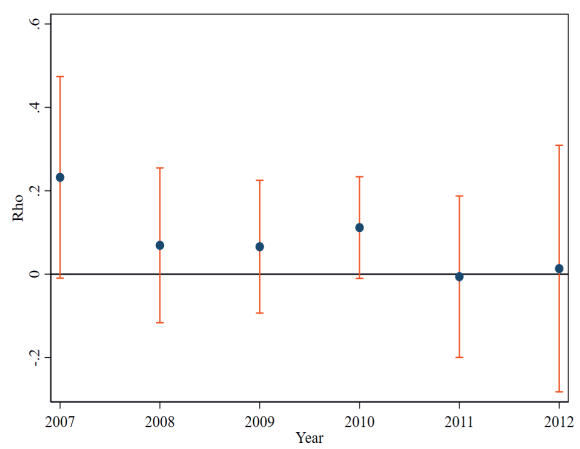

C. Alternatives - Common advisory actuarial firm

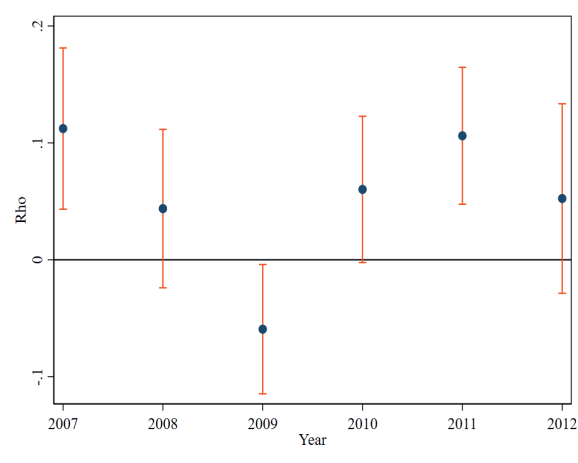

B. Alternatives - Common certifying actuary

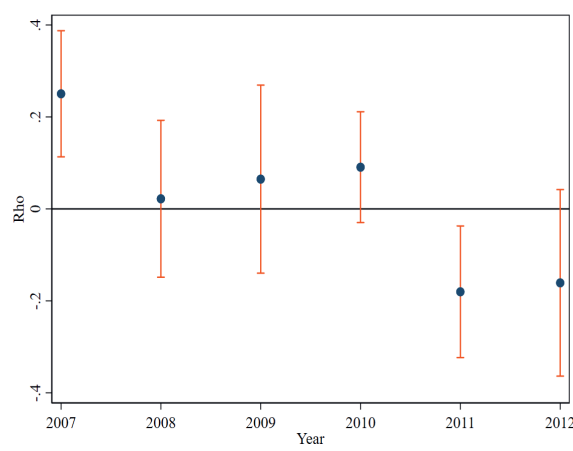

D. Alternatives - Common certifying actuarial firm

Notes: The figure displays the estimated rho coefficients with the corresponding $90 \%$ confidence interval from Equation [3.2]: $\mathbf{y}_{t}=\rho \mathbf{W} \mathbf{y}_{t}+\mathbf{X}_{t} \beta+\boldsymbol{\mu}+\boldsymbol{\theta}_{t}+\boldsymbol{\epsilon}_{t}$ where the dependent variable is the strategic allocation to alternative assets of each pension fund. Each model is estimated every year over the period from 2007-2012 on the subsequent five years. In panel A, we estimate the models using the weighting matrices built on pension funds with the same advisory actuary. In panel B, we estimate the models using the weighting matrices built on pension funds with the same certifying actuary. In panel $\mathrm{C}$, we estimate the models using the weighting matrices built on pension funds with advisory actuaries from the same firm. In panel D, we estimate the models using the weighting matrices built on pension funds with certifying actuaries from the same firm.

plays the $\rho$ coefficients that were estimated based on the common advisory actuaries. The coefficients are larger in magnitude and more significant than those that were estimated based on the common certifying actuaries in Panel B. Pension funds that contract the same advisory actuary have positive and significant correlation coefficients among their strategic allocations to alternatives over the entire sample period, while pension funds that contract the same certifying actuaries have positive and 
significant correlation coefficients only in 2007 and 2011 18

Furthermore, the influence that actuaries have on the SAAs of their clients could be driven by the firm that they work for. Actuarial companies typically provide models and tools to perform the ALM study for their actuaries. Actuaries from the same firm use models that reflect the same underlying assumptions, for example, on the factors that drive asset class returns. Therefore, the common-actuary effect might capture the fact that actuaries use the same technical tools. To test whether this effect exists we estimate Equation (3.2) separately for pension funds with the same advisory actuarial firm and pension funds with the same certifying actuarial firm. We find no evidence of an effect in alternatives. Panel $\mathrm{C}$ in Figure 3-5 shows highly non-significant $\rho$ coefficients for the models that were estimated with pension funds with the same advisory actuarial firm. Panel D also shows non-significant $\rho$ coefficients for the models estimated with pension funds with the same certifying actuarial firm 19

To summarize, our findings indicate that the common-actuary effect is mostly driven by advisory actuaries. Via their consulting activity they are in a better position to affect the investment decisions of pension funds. Moreover, the common-actuary effect is not driven by the actuarial firm of actuaries. Therefore, individual actuaries are able to transfer their private investment beliefs to their clients.

\subsubsection{Overlapping-trustees effect on the SAAs}

Our third hypothesis is that overlapping trustees lead to similarities among SAAs. In the previous sections we found the existence of a common-advisor effect. Common advisors transfer their investment beliefs to the trustees during their advisory activity; hence, they affect the SAAs. Trustees are in charge of the SAA, and legislation allows trustees to be appointed to multiple boards. In the case of multiple appoint-

\footnotetext{
${ }^{18}$ We have similar findings for private equity, real estate, hedge funds, and commodities. The results are displayed in supplementary Figures 1 and 2 in the online appendix at https://www.mb onetti.com/

${ }^{19} \mathrm{We}$ report the results of the analysis for all other asset classes in supplementary Figures 3 and 4 of the online appendix.
} 
ments, individual trustees will likely behave similarly across different pension funds for various reasons. The same person will in fact have the same investment beliefs and preferences (Malmendier and Nagel (2011), Dohmen et al., 2017) despite the specific characteristics of the pension fund in which they are appointed. Therefore, one may argue that the common-advisor effect that we find is in fact a mere manifestation of an overlapping-trustee effect; namely, individual trustees that make similar strategic investment decisions across different pension funds.

We test this overlapping-trustee effect by using the networks of pension funds that have overlapping trustees each year from 2007 to 2016. Next, we estimate Equation 3.2 where the weighting matrix $W$ equals one when two pension funds have the same trustee sitting on their boards ${ }^{20}$

In Figure 3-6, we display the regression coefficients that were estimated based on the weighting matrices that originate from the appointments of trustees in 2007, 2008, 2009, 2010, 2011, and 2012. Each year, and for each asset class, we estimate the overlapping-trustee effect on the subsequent five years, which is in line with prior analyses. Such a time range is also in line with the average tenure of a trustee, that is, six years (see Table 3.1). The results provide weak evidence in support of an overlapping-trustee effect in alternative asset classes. Moreover, there is no evidence of this effect in public equity and fixed income. In fact, for fixed income we even observe two negative spatial correlation coefficients that indicate that pension funds with the same trustees in 2011 and 2012 have SAAs that move in the opposite direction in the subsequent five years. In Figure 3-7. we replicate the analysis for each alternative asset class. Only pension funds that contract the same trustees in 2007 , 2009, 2010, and 2011 have significantly positive correlations in their private equity strategic portfolios over the subsequent five years. Evidence of an overlapping-trustee

\footnotetext{
${ }^{20}$ Endogeneity concerns also hold for overlapping trustees. Suppose that pension fund $A$ is advised to invest in alternative asset class $z$. Because the pension fund's trustees are not particularity knowledgeable on this asset class, they decide to hire independent trustee $y$ who has an expertise in $z$. This trustee already works for pension fund $B$. To avoid this reverse causality we exclude all independent trustees from the sample. We consider only overlaps among the representatives of employer, employees, and retirees. These are appointed by the social partners based on representation criteria rather than based on their specific investment expertise.
} 
Figure 3-6. Overlapping-trustee effect on SAAs

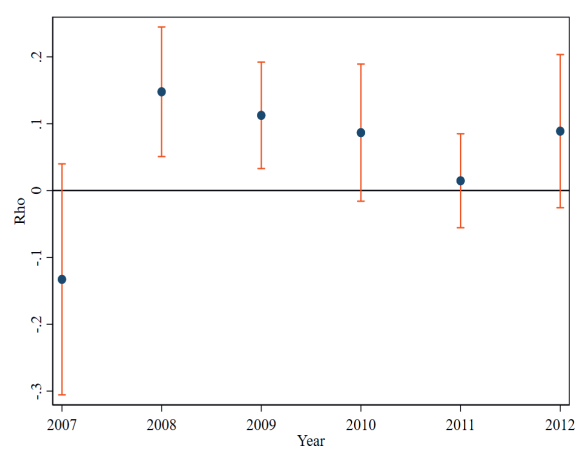

A. Alternatives

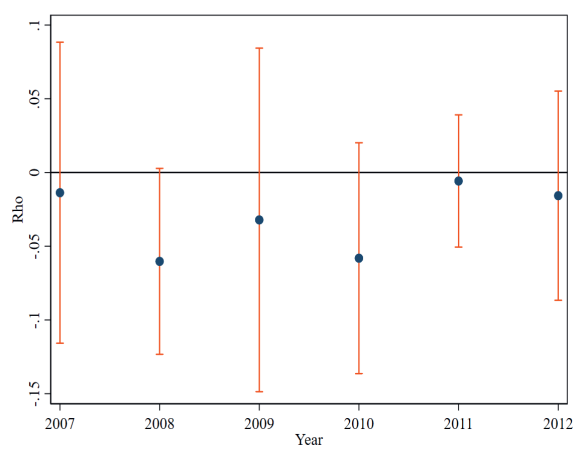

B. Equity

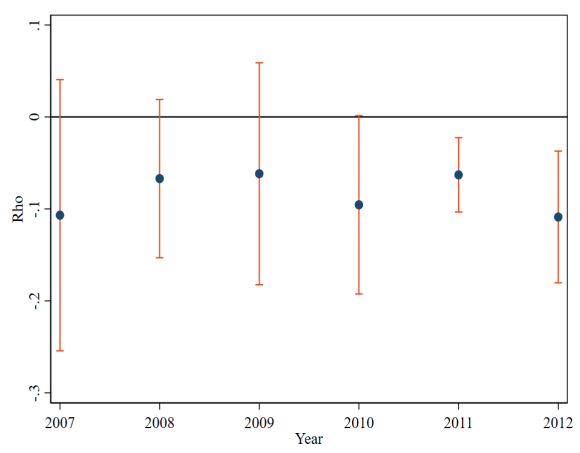

C. Fixed income

Notes: The figure displays the estimated rho coefficients with the corresponding $90 \%$ confidence interval from Equation 3.2: $\mathbf{y}_{t}=\rho \mathbf{W y}_{t}+\mathbf{X}_{t} \beta+\boldsymbol{\mu}+\boldsymbol{\theta}_{t}+\boldsymbol{\epsilon}_{t}$. The model is estimated every year over the period from 2007-2012 on the subsequent five years. Every year, we use the weighting matrix built on pension funds that have at least one overlapping trustee. In panel $\mathrm{A}$ the dependent variable is the strategic allocation to alternative assets of each pension fund, in Panel $\mathrm{B}$ the dependent variable is the strategic allocation to equity, and in Panel $\mathrm{C}$ the strategic allocation to fixed income. 
Figure 3-7. Overlapping-trustee effect on alternative assets

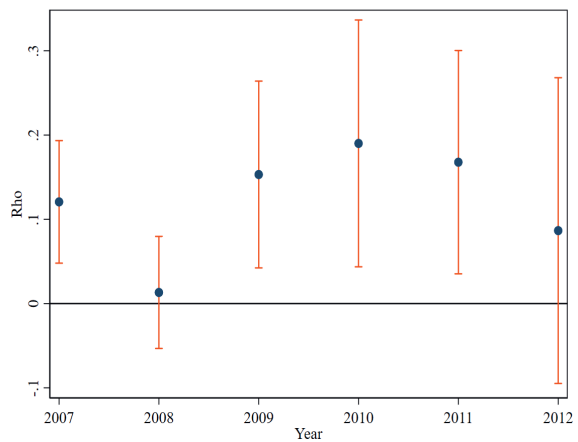

A. Private equity

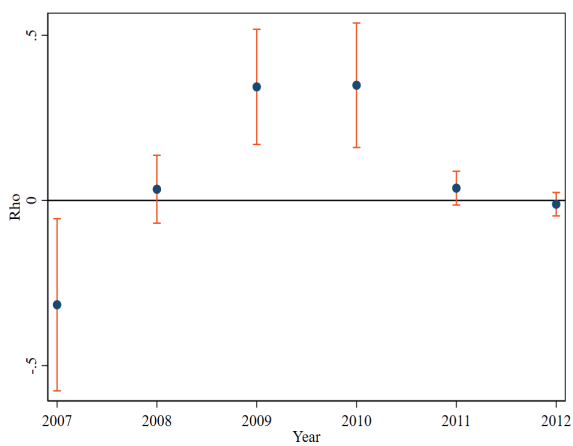

C. Hedge funds

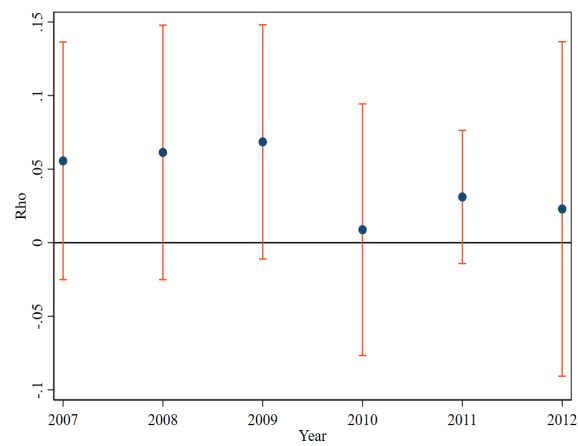

B. Real estate

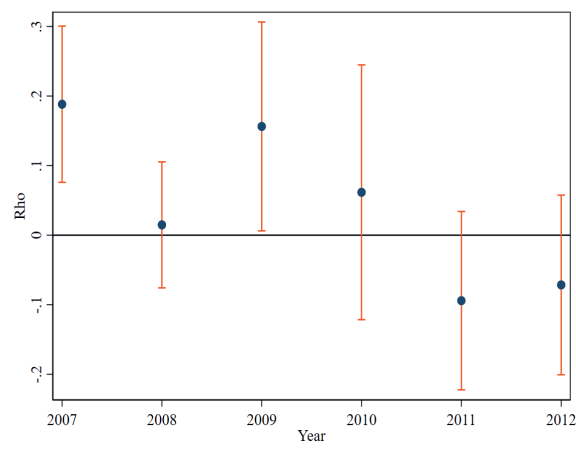

D. Commodities

Notes: The figure displays the estimated rho coefficients with the corresponding $90 \%$ confidence interval from Equation [3.2: $\mathbf{y}_{t}=\rho \mathbf{W y}_{t}+\mathbf{X}_{t} \beta+\boldsymbol{\mu}+\boldsymbol{\theta}_{t}+\boldsymbol{\epsilon}_{t}$. The model is estimated every year over the period from 2007-2012 on the subsequent five years. Every year, we use the weighting matrix built on pension funds that have at least one overlapping trustee. In panel A the dependent variable is the strategic allocation to private equity of each pension fund, in Panel $\mathrm{B}$ the dependent variable is the strategic allocation to real estate, in Panel $\mathrm{C}$ the dependent variable is the strategic allocation to hedge funds, and in Panel D the dependent variables if the strategic allocation to commodities.

effect is nearly nonexistent in real estate, hedge funds, and commodities ${ }^{21}$

To summarize, our findings indicate that individual trustees are not able to transfer their investment beliefs to other board members, unlike common advisors. In practice, the influence of individual trustees on the SAA is limited. One person alone

\footnotetext{
${ }^{21}$ Trustees that are also members of the investment committee might have more financial knowledge and a greater involvement in the investment decisions. We also test the overlapping-trustee effect by considering only multiple appointments of trustees who are also in the investment committee. The results are unchanged (unreported analysis, the results are available on request to the authors).
} 
cannot stir the collegial decisions of a board, let alone multiple boards at different pension funds. Even though some highly influential, experienced, or knowledgeable trustees might succeed in transferring their investment beliefs to the other board members.

\subsubsection{Common pension fund characteristics and SAAs}

Our fourth hypothesis is that common pension fund characteristics lead to similarities in SAAs. Pension funds with a similar liability duration have a similar age composition in terms of beneficiaries. For example, pension funds with a low liability duration have a high number of retirees. These pension funds have a comparable investment horizon and similar cash flow requirements and therefore they should make similar strategic investment decisions (Broeders et al. (2020)). To test the hypothesis, we estimate Equation 3.2 with a weighting matrix that equals one when two pension funds are in the same quartile of the distribution of the average liability duration, and zero otherwise. Specifically, two pension funds are "neighbors" if they have a similar average liability duration ${ }^{22}$ Panel A of Table 3.5 shows the results. We find that pension funds in the same maturity group do not make similar investment decisions over time. All asset classes have either a non-significant or a negative $\rho$ that means the pension funds with similar liability durations have SAAs that are not related to each other or even move in the opposite direction over time, for example, in commodities and private equity.

We repeat the same analysis for pension funds with similar funding ratios or sizes. Panel B in Table 3.5 shows that pension funds with similar funding ratios have SAAs that are not correlated. Conversely, pension funds of similar size display a positive correlation in the strategic allocations to private equity, real estate, and public equity.

\footnotetext{
${ }^{22}$ The $\mathbf{W}$ is constant over time as we compute the time-series average of the liability duration of each pension fund, and then we separate pension funds into four quartiles. We chose this approach because the liability duration is a rather stable measure. The heterogeneity in such a measure is given by the different composition of the labor force in each sector or company. Therefore, if changes occur in the demographic structure of a pension fund, these occur very slowly over time. On the other hand, interest rate fluctuations affect the liability duration of all pension funds equally. In sum, pension funds that are in the first quartile of the liability duration distribution are likely to stay in the same quartile in the subsequent years.
} 
Table 3.5: Portfolio evolution of pension funds with similar characteristics

\begin{tabular}{|c|c|c|c|c|c|c|c|}
\hline & \multicolumn{7}{|c|}{ A. Pension funds with same liability duration } \\
\hline & Alternatives & Commodities & $\begin{array}{l}\text { Private } \\
\text { equity }\end{array}$ & $\begin{array}{l}\text { Hedge } \\
\text { funds }\end{array}$ & $\begin{array}{c}\text { Real } \\
\text { estate }\end{array}$ & Equity & $\begin{array}{l}\text { Fixed } \\
\text { income }\end{array}$ \\
\hline$\rho$ & $\begin{array}{c}-0.1660 \\
(-1.09)\end{array}$ & $\begin{array}{c}-0.2820^{* *} \\
(-1.97)\end{array}$ & $\begin{array}{c}-0.3250^{* *} \\
(-2.55)\end{array}$ & $\begin{array}{c}-0.0889 \\
(-0.48)\end{array}$ & $\begin{array}{c}-0.0174 \\
(-0.14)\end{array}$ & $\begin{array}{c}0.00403 \\
(0.03)\end{array}$ & $\begin{array}{c}-0.0843 \\
(-0.72)\end{array}$ \\
\hline Duration & $\begin{array}{l}-0.166 \\
(-1.11)\end{array}$ & $\begin{array}{c}0.0221 \\
(0.49)\end{array}$ & $\begin{array}{c}-0.0221 \\
(-0.58)\end{array}$ & $\begin{array}{l}-0.118 \\
(-1.31)\end{array}$ & $\begin{array}{c}-0.0499 \\
(-0.66)\end{array}$ & $\begin{array}{l}0.156 \\
(0.58)\end{array}$ & $\begin{array}{l}0.331 \\
(0.93)\end{array}$ \\
\hline Funding ratio & $\begin{array}{c}-0.0261^{*} \\
(-1.78)\end{array}$ & $\begin{array}{c}-0.0023 \\
(-0.58)\end{array}$ & $\begin{array}{c}-0.0035 \\
(-1.06)\end{array}$ & $\begin{array}{c}-0.0039 \\
(-0.69)\end{array}$ & $\begin{array}{c}-0.0165^{*} \\
(-1.70)\end{array}$ & $\begin{array}{c}-0.0160 \\
(-0.89)\end{array}$ & $\begin{array}{l}0.0276 \\
(1.21)\end{array}$ \\
\hline Log size & $\begin{array}{l}0.137 \\
(0.41) \\
\end{array}$ & $\begin{array}{c}-0.0542 \\
(-0.37) \\
\end{array}$ & $\begin{array}{l}0.0135 \\
(0.22) \\
\end{array}$ & $\begin{array}{r}0.138 \\
(0.86) \\
\end{array}$ & $\begin{array}{c}0.0519 \\
(0.27) \\
\end{array}$ & $\begin{array}{c}1.728^{* *} \\
(2.49) \\
\end{array}$ & $\begin{array}{l}0.874 \\
(0.40) \\
\end{array}$ \\
\hline \multirow[t]{2}{*}{$R^{2}$} & $\begin{array}{c}1,910 \\
0.08\end{array}$ & $\begin{array}{c}1,910 \\
0.02 \\
\end{array}$ & $\begin{array}{c}1,910 \\
0.03 \\
\end{array}$ & $\begin{array}{c}1,910 \\
0.05\end{array}$ & $\begin{array}{c}1,910 \\
0.02 \\
\end{array}$ & $\begin{array}{c}1,910 \\
0.01\end{array}$ & $\begin{array}{c}1,910 \\
0.04\end{array}$ \\
\hline & \multicolumn{7}{|c|}{ B. Pension funds with same funding ratio } \\
\hline$\rho$ & $\begin{array}{c}-0.1754 \\
(-0.99)\end{array}$ & $\begin{array}{c}-0.1559 \\
(-1.19)\end{array}$ & $\begin{array}{c}-0.0054 \\
(-0.06)\end{array}$ & $\begin{array}{c}0.0278 \\
(0.14)\end{array}$ & $\begin{array}{c}-0.1579 \\
(-1.12)\end{array}$ & $\begin{array}{c}-0.1161 \\
(-0.60)\end{array}$ & $\begin{array}{c}-0.0373 \\
(-0.27)\end{array}$ \\
\hline Duration & $\begin{array}{c}-0.1693 \\
(-1.13)\end{array}$ & $\begin{array}{l}0.0201 \\
(0.45)\end{array}$ & $\begin{array}{c}-0.0190 \\
(-0.50)\end{array}$ & $\begin{array}{c}-0.1164 \\
(-1.27)\end{array}$ & $\begin{array}{c}-0.0515 \\
(-0.68)\end{array}$ & $\begin{array}{l}0.1511 \\
(0.57)\end{array}$ & $\begin{array}{l}0.3240 \\
(0.92)\end{array}$ \\
\hline Funding ratio & $\begin{array}{c}-0.0269^{*} \\
(-1.80)\end{array}$ & $\begin{array}{c}-0.0026 \\
(-0.65)\end{array}$ & $\begin{array}{c}-0.0034 \\
(-1.05)\end{array}$ & $\begin{array}{c}-0.0039 \\
(-0.69)\end{array}$ & $\begin{array}{c}-0.0166^{*} \\
(-1.69)\end{array}$ & $\begin{array}{c}-0.0140 \\
(-0.79)\end{array}$ & $\begin{array}{l}0.0269 \\
(1.19)\end{array}$ \\
\hline $\log$ size & $\begin{array}{r}0.1537 \\
(0.47) \\
\end{array}$ & $\begin{array}{c}-0.0480 \\
(-0.33) \\
\end{array}$ & $\begin{array}{l}0.0108 \\
(0.18) \\
\end{array}$ & $\begin{array}{r}0.1252 \\
(0.73) \\
\end{array}$ & $\begin{array}{r}0.0629 \\
(0.32) \\
\end{array}$ & $\begin{array}{c}1.7387^{* *} \\
(2.48)\end{array}$ & $\begin{array}{l}0.9121 \\
(0.41) \\
\end{array}$ \\
\hline$N$ & 1910 & 1910 & 1910 & 1910 & 1910 & 1910 & 1910 \\
\hline \multirow[t]{2}{*}{$R^{2}$} & 0.0910 & 0.0133 & 0.0212 & 0.0526 & 0.0323 & 0.0042 & 0.0416 \\
\hline & \multicolumn{7}{|c|}{ C. Pension funds with same size } \\
\hline$\rho$ & $\begin{array}{c}0.0685 \\
(0.51)\end{array}$ & $\begin{array}{c}-0.4767^{* * *} \\
(-3.29)\end{array}$ & $\begin{array}{c}0.4651^{* * *} \\
(5.78)\end{array}$ & $\begin{array}{c}-0.2940 \\
(-1.57)\end{array}$ & $\begin{array}{c}0.4186^{* * *} \\
(5.35)\end{array}$ & $\begin{array}{c}0.2443^{* *} \\
(2.08)\end{array}$ & $\begin{array}{c}0.1472 \\
(1.29)\end{array}$ \\
\hline Duration & $\begin{array}{c}-0.1658 \\
(-1.11)\end{array}$ & $\begin{array}{c}0.0191 \\
(0.43)\end{array}$ & $\begin{array}{c}-0.0151 \\
(-0.41)\end{array}$ & $\begin{array}{c}-0.1184 \\
(-1.30)\end{array}$ & $\begin{array}{c}-0.0579 \\
(-0.77)\end{array}$ & $\begin{array}{l}0.1444 \\
(0.55)\end{array}$ & $\begin{array}{l}0.3257 \\
(0.93)\end{array}$ \\
\hline Funding ratio & $\begin{array}{c}-0.0265^{*} \\
(-1.80)\end{array}$ & $\begin{array}{c}-0.0025 \\
(-0.61)\end{array}$ & $\begin{array}{c}-0.0025 \\
(-0.77)\end{array}$ & $\begin{array}{c}-0.0041 \\
(-0.70)\end{array}$ & $\begin{array}{c}-0.0178^{*} \\
(-1.79)\end{array}$ & $\begin{array}{c}-0.0189 \\
(-1.07)\end{array}$ & $\begin{array}{l}0.0290 \\
(1.26)\end{array}$ \\
\hline Log size & $\begin{array}{c}0.1471 \\
(0.44) \\
\end{array}$ & $\begin{array}{r}-0.0565 \\
(-0.39) \\
\end{array}$ & $\begin{array}{l}0.0199 \\
(0.34) \\
\end{array}$ & $\begin{array}{l}0.1225 \\
(0.72) \\
\end{array}$ & $\begin{array}{r}0.0756 \\
(0.39) \\
\end{array}$ & $\begin{array}{c}1.7235^{* *} \\
(2.49) \\
\end{array}$ & $\begin{array}{l}0.9252 \\
(0.42) \\
\end{array}$ \\
\hline $\begin{array}{l}N \\
R^{2}\end{array}$ & $\begin{array}{c}1910 \\
0.0902\end{array}$ & $\begin{array}{c}1910 \\
0.0129\end{array}$ & $\begin{array}{c}1910 \\
0.0871\end{array}$ & $\begin{array}{c}1910 \\
0.0468\end{array}$ & $\begin{array}{c}1910 \\
0.0517\end{array}$ & $\begin{array}{c}1910 \\
0.0031\end{array}$ & $\begin{array}{c}1910 \\
0.0483\end{array}$ \\
\hline
\end{tabular}

Notes: Panel A shows the estimation results of Equation 3.2 namely the spatial panel autoregressive model $\mathbf{y}_{t}=$ $\rho \mathbf{W y}_{t}+\mathbf{X}_{t} \beta+\boldsymbol{\mu}+\boldsymbol{\theta}_{t}+\boldsymbol{\epsilon}_{t}$ for pension funds with similar average liability durations. The dependent variable $\mathbf{y}_{t}$ contains the strategic allocation to each asset class of each pension fund in year $t$. The $\rho$ is the coefficient that describes the spatial correlation among the strategic portfolio weights of pension funds with similar liability durations. The W equals one when two pension funds are in the same quartile of the distribution of the average liability duration, and zero otherwise. The $\mathbf{W}$ is constant over time as we compute the time-series average of the liability duration of each pension fund, and then we separate it into four quartiles. $\mathbf{X}_{t}$ is a set of control variables: funding ratio, size, and liability duration of each pension fund. The model is estimated on the entire sample period: 2007-2016. A positive and significant $\rho$ means that pension funds with similar liabilities have portfolio weights (SAAs) that move in the same direction over time. Panel B shows the estimation results of Equation 3.2 for pension funds with similar funding ratios. In this case, $\mathbf{W}$ equals one when two pension funds are in the same quartile of the distribution of the average funding ratio, and zero otherwise. Panel $\mathrm{C}$ shows the estimation results of Equation 3.2 for pension funds with similar sizes. In this case, $\mathbf{W}$ equals one when two funds are in the same quartile of the distribution of the average total assets, and zero otherwise. All models are estimated with pension fund and time fixed effects $\boldsymbol{\mu}$ and $\boldsymbol{\theta}_{t}$. The t-statistics are in parentheses. The * indicates statistical significance at the $10 \%$ level, ${ }^{* *}$ at the $\% 5$ level, and *** at the $1 \%$ level.

Size correlates with the cost structures and investment skills of pension funds. These similarities can explain why pension funds of similar size are likely to trade the same assets at the same time. Also, it is reasonable to believe that trustees of pension funds of similar size communicate and discuss investment opportunities with each other. 


\subsubsection{Discussion of the key findings}

Our results indicate that a common-advisor effect on the SAAs of pension funds exists. Pension funds that contract the same asset manager make similar investment decisions in all asset classes, except real estate. Many Dutch pension funds rely on fiduciary asset managers that are directly involved in the design of the SAA. Such an advisory activity allows fiduciaries to transfer their investment beliefs to the trustees. In the case of an execution-only mandate, asset managers' expertise, reputation, and negotiating power may still influence trustees' decisions. ${ }^{23}$ Pension funds that contract the same advisory actuaries also make similar investment decisions in their alternatives portfolios. Actuaries contribute to the design of the ALM study. Therefore, finding similar SAA decisions among pension funds with the same actuary despite differences in liability duration indicates that the actuaries' investment beliefs are included in the design of the SAAs with the matching liability criterion. Because of their technical expertise, actuaries' opinions about the SAA can be valuable and influential for trustees. Strikingly, pension funds with a similar liability duration and funding ratio do not make similar investment decisions over time. Pension funds of similar size do exhibit portfolio comovements in equity, private equity and real estate.

\subsection{Robustness checks}

We run two robustness checks to ensure that similar investment decisions can in fact be associated with the common-advisor effect and not to other factors. First, we test the hypothesis that pension funds follow each other's strategic investment decisions over time rather than responding to a common-advisor effect. Second, we test the hypothesis that similar SAAs originate from a trend in asset classes rather than from a common-advisor effect.

\footnotetext{
${ }^{23}$ Because we cannot distinguish between fiduciary and execution-only mandates, we cannot say which of the two mandates affect the SAA more.
} 


\subsubsection{Time dynamics in the SAA decisions}

We find that pension funds make similar investment decisions based on contracting with the same asset managers or actuaries. We interpret this finding as a commonadvisor effect. Another potential explanation is that pension funds have a tendency to replicate the past investment decisions of other pension funds (Lakonishok et al. (1992b), Blake et al. (2017)). To measure if similar investment decisions are driven by a common-advisor effect or by this replication, we rely on a dynamic model that captures both dimensions. This model tests whether the investment decisions of a pension fund are affected by both the current and the past investment decisions of pension funds with the same asset managers, the same actuaries, or that have overlapping trustees. The dynamic model is specified as follows:

$$
\mathbf{y}_{t}=\lambda \mathbf{y}_{t-1}+\rho \mathbf{W y}_{t}+\gamma \mathbf{W y}_{t-1}+\mathbf{X}_{t} \beta+\boldsymbol{\mu}+\boldsymbol{\theta}_{t}+\boldsymbol{\epsilon}_{t}
$$

where vector $\mathbf{y}_{t}$ includes the strategic allocation to a specific asset class of each pension fund in year $t$, and $\mathbf{y}_{t-1}$ is the strategic asset allocation in the same asset class the year before. Therefore, the $\lambda$ coefficient captures the autocorrelation among portfolio weights of the same pension fund. Autocorrelation mechanically occurs if pension funds spread changes in their SAAs over subsequent years. $\mathbf{W y}_{t}$ is the spatially lagged variable, and $\mathbf{W} \mathbf{y}_{t-1}$ contains the lagged SAAs of pension funds that contract the same asset managers, the same actuaries, or that have at least one overlapping trustee. $\mathbf{X}_{t}$ is the usual set of pension fund characteristics. We estimate the model with pension fund and year fixed effects.

Table 3.6 presents the estimation results of Equation 3.3 for pension funds that contract with the same asset manager. In line with the results of the static model (in Table 3.4), the $\rho$ coefficient is positive and significant both for alternative asset classes and for standard asset classes. The size of the coefficients is also similar to the size of the coefficients estimated in the static model. All asset classes display positive and significant $\lambda$ coefficients. Namely, the strategic portfolio weights in each asset class are positively correlated with their lagged values. This correlation shows 
Table 3.6: Common-asset manager effect on the SAAs - Dynamic specification

\begin{tabular}{|c|c|c|c|c|c|c|c|}
\hline & \multicolumn{6}{|c|}{ Common-asset manager effect on SAA - 2012-2016 } & \multirow[b]{2}{*}{$\begin{array}{l}\text { Fixed } \\
\text { income }\end{array}$} \\
\hline & Alternatives & Commodities & $\begin{array}{l}\text { Private } \\
\text { equity }\end{array}$ & $\begin{array}{l}\text { Hedge } \\
\text { funds }\end{array}$ & $\begin{array}{c}\text { Real } \\
\text { estate }\end{array}$ & Equity & \\
\hline$\rho$ & $\begin{array}{c}0.2592^{* *} \\
(2.50)\end{array}$ & $\begin{array}{l}0.3428^{* * *} \\
(3.38)\end{array}$ & $\begin{array}{c}0.4448^{* * *} \\
\quad(4.64)\end{array}$ & $\begin{array}{c}0.3899^{* * *} \\
(5.32)\end{array}$ & $\begin{array}{l}0.0759 \\
(0.97)\end{array}$ & $\begin{array}{l}0.2986^{* * *} \\
(4.22)\end{array}$ & $\begin{array}{c}0.4057^{* * *} \\
(4.83)\end{array}$ \\
\hline Alternative $_{t-1}$ & $\begin{array}{c}0.8351^{* * *} \\
(14.30)\end{array}$ & & & & & & \\
\hline $\mathrm{W}^{*}$ Alternative $_{t-1}$ & $\begin{array}{c}-0.1603 \\
(-1.51)\end{array}$ & & & & & & \\
\hline Commodities $_{t-1}$ & & $\begin{array}{c}0.7204^{* * *} \\
(11.22)\end{array}$ & & & & & \\
\hline $\mathrm{W}^{*}$ Commodities $_{t-1}$ & & $\begin{array}{c}-0.2767^{* *} \\
(-2.32)\end{array}$ & & & & & \\
\hline Private equity $t-1$ & & & $\begin{array}{c}0.7363^{* * *} \\
(12.76)\end{array}$ & & & & \\
\hline $\mathrm{W}^{*}$ Private equity $t-1$ & & & $\begin{array}{c}-0.1258 \\
(-1.15)\end{array}$ & & & & \\
\hline Hedge funds ${ }_{t-1}$ & & & & $\begin{array}{c}0.7907^{* * *} \\
(15.23)\end{array}$ & & & \\
\hline $\mathrm{W}^{*}$ Hedge funds $t-1$ & & & & $\begin{array}{l}0.1177 \\
(1.20)\end{array}$ & & & \\
\hline Real estate $_{t-1}$ & & & & & $\begin{array}{c}0.9595^{* * *} \\
(10.89)\end{array}$ & & \\
\hline $\mathrm{W}^{*}$ Real estate ${ }_{t-1}$ & & & & & $\begin{array}{c}-0.1996^{* *} \\
(-2.30)\end{array}$ & & \\
\hline Equity $_{t-1}$ & & & & & & $\begin{array}{c}0.4699^{* * *} \\
\quad(8.19)\end{array}$ & \\
\hline $\mathrm{W}^{*}$ Equity $_{t-1}$ & & & & & & $\begin{array}{l}0.0970 \\
(1.27)\end{array}$ & \\
\hline Fixed income $_{t-1}$ & & & & & & & $\begin{array}{c}0.6744^{* * *} \\
(9.59)\end{array}$ \\
\hline $\mathrm{W}^{*}$ Fixed income $t-1$ & & & & & & & $\begin{array}{c}-0.1221 \\
(-1.41)\end{array}$ \\
\hline Duration & $\begin{array}{c}-0.2294 \\
(-1.27)\end{array}$ & $\begin{array}{r}-0.0466 \\
(-0.47)\end{array}$ & $\begin{array}{l}0.0323 \\
(0.67)\end{array}$ & $\begin{array}{c}-0.0201 \\
(-0.37)\end{array}$ & $\begin{array}{c}-0.2032^{*} \\
(-1.91)\end{array}$ & $\begin{array}{c}-0.0462 \\
(-0.07)\end{array}$ & $\begin{array}{l}0.9519 \\
(1.09)\end{array}$ \\
\hline Funding Ratio & $\begin{array}{l}0.0037 \\
(0.44)\end{array}$ & $\begin{array}{l}0.0045 \\
(0.96)\end{array}$ & $\begin{array}{l}0.0007 \\
(0.33)\end{array}$ & $\begin{array}{c}0.0073^{* * *} \\
(2.87)\end{array}$ & $\begin{array}{c}-0.0090^{*} \\
(-1.79)\end{array}$ & $\begin{array}{c}-0.0334 \\
(-0.60)\end{array}$ & $\begin{array}{l}0.0123 \\
(0.20)\end{array}$ \\
\hline Log Size & $\begin{array}{c}0.4304^{* *} \\
(2.50) \\
\end{array}$ & $\begin{array}{l}0.1104 \\
(1.60) \\
\end{array}$ & $\begin{array}{r}-0.0405 \\
(-0.85) \\
\end{array}$ & $\begin{array}{l}0.0267 \\
(0.95) \\
\end{array}$ & $\begin{array}{c}0.4091^{* * *} \\
(4.13) \\
\end{array}$ & $\begin{array}{l}0.6306 \\
(1.52) \\
\end{array}$ & $\begin{array}{r}-0.3957 \\
(-0.42) \\
\end{array}$ \\
\hline Observations & 764 & 764 & 764 & 764 & 764 & 764 & 764 \\
\hline$R^{2}$ & 0.8595 & 0.6996 & 0.7604 & 0.7156 & 0.8703 & 0.2140 & 0.3344 \\
\hline
\end{tabular}

Notes: The table shows the estimation results for the dynamic spatial panel autoregressive model $\mathbf{y}_{t}=\lambda \mathbf{y}_{t-1}+$ $\rho \mathbf{W} \mathbf{y}_{t}+\gamma \mathbf{W y}_{t-1}+\mathbf{X}_{t} \beta+\boldsymbol{\mu}+\boldsymbol{\theta}_{t}+\boldsymbol{\epsilon}_{t}$ for pension funds that contract the same asset manager. The identification of the common asset manager is defined in Section 3.3.1 The dependent variable $\mathbf{y}_{t}$ is the SAA for each asset class of each pension fund in year $t$. The $\mathbf{W}$ is the weighting matrix that equals one if two pension funds contract the same asset manager and zero otherwise, and it is constant by construction. $\mathbf{W y}_{t}$ is the spatially lagged variable, and $\rho$ is the coefficient that describes the spatial correlation among the strategic portfolio weights of pension funds that contract the same asset manager. $\mathbf{W y}_{t-1}$ contains the lagged strategic portfolio weights of pension funds with the same asset manager. $\mathbf{X}_{t}$ are control variables: funding ratio, size, and the liability duration of each pension fund. The model is estimated with pension fund and year fixed effects. The model is estimated on the subsample of 2012-2016 to avoid reverse causality, as the contracts between pension funds and asset managers that define $\mathbf{W}$ that exists prior to 2012. The $\lambda$ coefficient captures the autocorrelation among portfolio weights in the same asset class. The $\gamma$ coefficient captures the spatial correlation with the lagged strategic portfolio weights of pension funds with the same asset manager. The t-statistics are in parentheses. The * indicates statistical significance at the $10 \%$ level, ${ }^{* *}$ at the $\% 5$ level, and $* * *$ at the $1 \%$ level.

that pension funds gradually adjust their strategic weights over time. Moreover, $\gamma$ coefficients are non-significant in both alternative and standard asset classes, or 
even negative in commodities $(\gamma=-0.2767)$ and real estate $(\gamma=-0.1996)$. Therefore, we reject the hypothesis that pension funds replicate the past investment decisions of other pension funds with common asset managers.

We then estimate the dynamic model for pension funds that contract the same actuary. As for the static model, we estimate Equation (3.3) with the weighting matrices that originate from the contracts between actuaries and pension funds in 2007, 2008, 2009, 2010, 2011, and 2012. Each year, and for each asset class, we estimate the common-actuary effect on the subsequent five years. For example, we build the weighting matrix to identify the common actuaries in 2007. We then test the effect of these common actuaries on the SAAs over the period from 2007 to 2011 . We repeat this analysis for each year up until the contracts existing in 2012. Panel A of Figure 3-8 shows the $\rho, \lambda$, and $\gamma$ coefficients together with their confidence intervals from the dynamic models that were estimated on the total strategic allocation to alternatives. The results indicate positive and significant $\rho$ coefficients. The $\gamma$ coefficients are typically either non-significant or negative, which indicates that pension funds do not replicate the past investment decisions of pension funds that contract the same actuary. Looking at each individual alternative asset class separately, we find a positive and significant $\rho$ and a non-significant $\gamma$ for private equity and real estate, which are in line with the results of the static model. Conversely, we find no common-actuary effect in hedge funds and commodities. Further, all asset classes display highly significant $\lambda$ coefficients, that is, pension funds adjust their strategic portfolios gradually over time ${ }^{24}$ Therefore, we also reject the hypothesis that pension funds replicate the past investment decisions of other pension funds with common actuaries.

In Panel B of Figure 3-8, we find weak evidence for an overlapping-trustee effect on the SAAs. The dynamic model that was estimated on the total allocation to alternatives presents positive and significant $\rho$ coefficients only in 2007 and 2008 . The $\gamma$ coefficients are non-significant. Therefore, we also reject the hypothesis that pension funds replicate the past investment decisions of other funds that appoint the same trustees. Further, $\lambda$ coefficients are positive and significant and indicate that

\footnotetext{
${ }^{24}$ The results are displayed in supplementary Figure 5 of the online appendix
} 


\section{Figure 3-8. Dynamic model for common actuaries and overlapping trustees}
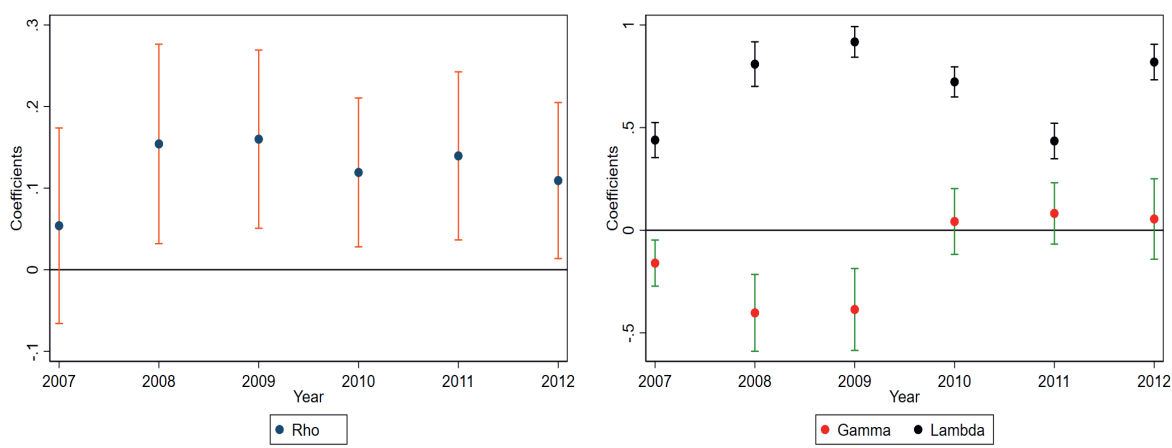

A. Alternatives - Dynamic model with common actuaries
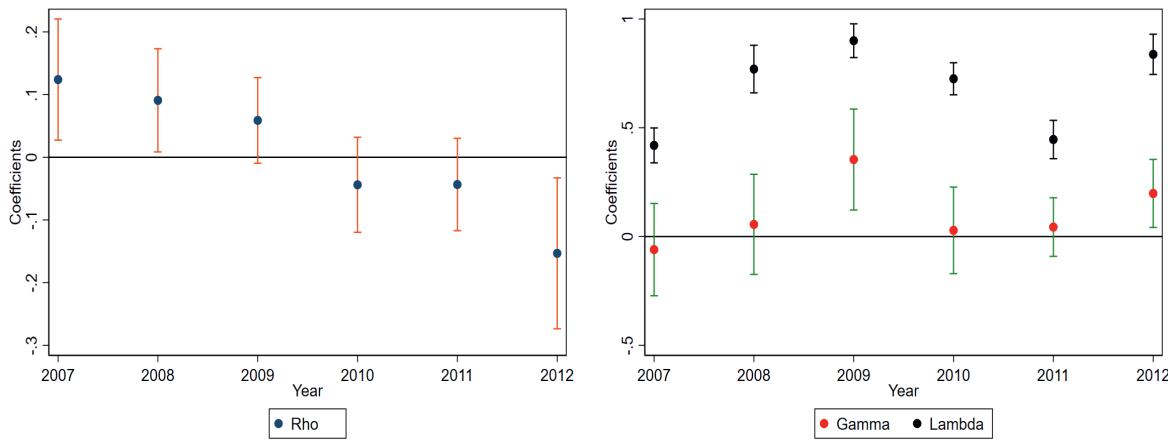

B. Alternatives - Dynamic model with overlapping trustees

Notes: The figure displays the estimated coefficients rho, lambda, and gamma with the corresponding $90 \%$ confidence interval from Equation (3.3): $\mathbf{y}_{t}=\lambda \mathbf{y}_{t-1}+\rho \mathbf{W y}_{t}+\gamma \mathbf{W} \mathbf{y}_{t-1}+\mathbf{X}_{t} \beta+\boldsymbol{\mu}+\boldsymbol{\theta}_{t}+\boldsymbol{\epsilon}_{t}$. All models in the figure are estimated with the strategic allocation to alternative assets as the dependent variable. The $\mathbf{W}$ is the weighting matrix that equals one when two funds contract the same actuary and zero otherwise in Panel A. In panel $\mathrm{B}$, $\mathbf{W}$ is the weighting matrix that equals one when two funds have at least one overlapping trustee and zero otherwise. $\mathbf{W y}_{t}$ is the spatially lagged variable, and $\rho$ is the coefficient that describes the spatial correlation among the strategic portfolio weights of pension funds that contract the same actuary (in Panel A) or that have at least one overlapping trustee (in Panel B). $\mathbf{W y}_{t-1}$ contains the lagged strategic portfolio weights of pension funds with the same actuary or that have at least one overlapping trustee. The $\lambda$ coefficient captures the autocorrelation among portfolio weights in the same asset class. The $\gamma$ coefficient captures the spatial correlation with the lagged strategic portfolio weights of pension funds with the same actuary or that have at least one overlapping trustee. The models are estimated every year over the period from 2007-2012 on the subsequent five years.

the pension funds spread changes to their SAAs over subsequent years ${ }^{25}$

To summarize, the results of the dynamic spatial autoregressive model in Equation 3.3 confirm the findings of the static spatial autoregressive model in Equation

\footnotetext{
${ }^{25}$ The results for each alternative asset class separately are available in supplementary Figure 6 of the online appendix.
} 
(3.2). Pension funds that contract with the same asset managers increase or decrease their strategic allocations to both standard and alternative asset classes in the same year. Pension funds that contract with the same actuary also increase or decrease their strategic allocations to alternatives in the same year. Pension funds that have overlapping trustees only show weak evidence for similar investment decisions. Overall, there is no evidence that supports the hypothesis that pension funds replicate the past investment decisions of other pension funds. In fact, pension funds make similar investment decisions because they respond to common signals (Froot et al. 1992, Hirshleifer et al. (1994)) that originate from common asset managers or common actuaries. Moreover, there is a strong autocorrelation among strategic portfolio weights in all asset classes. This result confirms that pension funds change their SAAs gradually over time.

\subsubsection{Spurious regressions concerns}

Because strategic portfolio changes are implemented gradually over time, portfolio weights might display a trend over the 5 -year subperiods that we consider for our analysis. Multiple appointments of asset managers, actuaries, and trustees also could display a trend over the same subperiods. In order to avoid any possible concern for spurious correlations, we test the following model:

$$
\Delta \mathbf{y}_{t}=\rho \mathbf{W} \Delta \mathbf{y}_{t}+\mathbf{X}_{t} \beta+\boldsymbol{\mu}+\boldsymbol{\theta}_{t}+\boldsymbol{\epsilon}_{t}
$$

where $\Delta \mathbf{y}_{t}$ is the change in the strategic portfolio weight in each asset class between year $t$ and year $t-1$ for each pension fund. All other variables have the same interpretation as in Equation (3.2). The $\rho$ coefficient still represents the commonadvisor effect and overlapping-trustee effect. With this approach we de-trend $\mathbf{y}_{t}$ by taking its first difference. This de-trending allows us to avoid any possible concern for spurious correlations.

Table 3.7presents the results of the first-difference model estimated on the SAAs of pension funds that contract with the same asset manager. The $\rho$ coefficient is positive 
Table 3.7: Common-asset-manager effect on SAAs - First-difference analysis

\begin{tabular}{|c|c|c|c|c|c|c|c|}
\hline & \multicolumn{7}{|c|}{ Common-asset manager effect on changes in SAA - 2012-2016 } \\
\hline & Alternatives & Commodities & $\begin{array}{l}\text { Private } \\
\text { equity }\end{array}$ & $\begin{array}{l}\text { Hedge } \\
\text { funds }\end{array}$ & $\begin{array}{c}\text { Real } \\
\text { estate }\end{array}$ & Equity & $\begin{array}{l}\text { Fixed } \\
\text { income }\end{array}$ \\
\hline$\rho$ & $\begin{array}{c}0.1784^{* *} \\
(2.03)\end{array}$ & $\begin{array}{c}0.3419^{* * *} \\
(3.82)\end{array}$ & $\begin{array}{c}0.3733^{* * *} \\
(4.32)\end{array}$ & $\begin{array}{l}0.0087 \\
(0.10)\end{array}$ & $\begin{array}{c}0.3934^{* * *} \\
(4.57)\end{array}$ & $\begin{array}{c}0.2606^{* * *} \\
(3.51)\end{array}$ & $\begin{array}{c}0.3538^{* * *} \\
(4.07)\end{array}$ \\
\hline Duration & $\begin{array}{l}0.2135 \\
(1.12)\end{array}$ & $\begin{array}{c}0.0450 \\
(0.54)\end{array}$ & $\begin{array}{l}0.1097 \\
(1.60)\end{array}$ & $\begin{array}{l}0.0025 \\
(0.02)\end{array}$ & $\begin{array}{l}0.0487 \\
(0.95)\end{array}$ & $\begin{array}{c}-0.1342 \\
(-0.25)\end{array}$ & $\begin{array}{l}0.1607 \\
(0.22)\end{array}$ \\
\hline Funding Ratio & $\begin{array}{l}0.0155 \\
(1.07)\end{array}$ & $\begin{array}{c}0.0139^{* *} \\
(2.41)\end{array}$ & $\begin{array}{c}0.0129^{* *} \\
(2.18)\end{array}$ & $\begin{array}{c}-0.0115 \\
(-1.47)\end{array}$ & $\begin{array}{l}0.0005 \\
(0.20)\end{array}$ & $\begin{array}{c}-0.0362 \\
(-0.79)\end{array}$ & $\begin{array}{c}-0.0015 \\
(-0.02)\end{array}$ \\
\hline Log Size & $\begin{array}{l}0.2153 \\
(1.10) \\
\end{array}$ & $\begin{array}{c}0.1443^{*} \\
(1.90) \\
\end{array}$ & $\begin{array}{c}-0.1595 \\
(-1.22) \\
\end{array}$ & $\begin{array}{c}0.2991^{* * *} \\
(4.01)\end{array}$ & $\begin{array}{c}-0.0652^{*} \\
(-1.70) \\
\end{array}$ & $\begin{array}{c}0.4400 \\
(1.50)\end{array}$ & $\begin{array}{c}-0.0809 \\
(-0.10)\end{array}$ \\
\hline Observations & 955 & 955 & 955 & 955 & 955 & 955 & 955 \\
\hline$R^{2}$ & 0.0000 & 0.0001 & 0.0082 & 0.0026 & 0.0019 & 0.0003 & 0.0001 \\
\hline
\end{tabular}

Notes: The table shows the estimation results of Equation 3.4 namely the spatial panel autoregressive model $\mathbf{y}_{t}=$ $\rho \mathbf{W} \mathbf{y}_{t}+\mathbf{X}_{t} \beta+\boldsymbol{\mu}+\boldsymbol{\theta}_{t}+\boldsymbol{\epsilon}_{t}$ for pension funds that contract the same asset manager. The identification of the common asset manager is defined in Section 3.3.1 The dependent variable $\mathbf{y}_{t}$ contains the changes in the strategic asset allocations to each asset class of each pension fund between year $t$ and year $t-1$. The $\rho$ is the coefficient that describes the spatial correlation among the changes in strategic portfolio weights of pension funds that contract the same asset manager. The $\mathbf{W}$ equals one when two funds contract the same asset manager and zero otherwise, and it is constant by construction. $\mathbf{X}_{t}$ is a set of control variables: funding ratio, size, and liability duration of each pension fund. And, $\boldsymbol{\mu}$ and $\boldsymbol{\theta}_{t}$ indicate fund and year fixed effects. The model is estimated on the subsample of $2012-2016$ to avoid reverse causality. A positive and significant $\rho$ means that pension funds with the same asset manager change portfolio weights (SAAs) in the same direction over time. We estimate the models for each asset class separately and report the corresponding spatial coefficients and controls. The t-statistics are in parentheses. The $*$ indicates statistical significance at the $10 \%$ level, ${ }^{* *}$ at the $\% 5$ level, and $* * *$ at the $1 \%$ level.

and significant both in standard and alternative asset classes. The $\rho$ coefficients are also similar in magnitude to the $\rho$ estimated in Equation 3.2.

We also estimate the first-difference model for pension funds that contract the same actuary. As in the previous sections, we estimate Equation (3.4) with the weighting matrices that originate from the common actuaries and pension funds in 2007, 2008, 2009, 2010, 2011, and 2012. Each year, and for each asset class, we estimate the common-actuary effect on the subsequent five years. We repeat this analysis for each year up until 2012. Panel A of Figure 3-9 displays the results of the first-difference model estimated on the strategic allocations to alternatives. The $\rho$ coefficients are positive and significant. In line with prior findings, pension funds that contract the same actuary change their strategic allocations to alternatives in the same direction over time.

We then apply the same procedure to estimate the first-difference model for pension funds that have at least one overlapping trustee. Panel B of Figure 3-9 shows the results of the first-difference model that was estimated on the strategic allocations 
Figure 3-9. First-difference model for pension funds with common actuaries or overlapping trustees

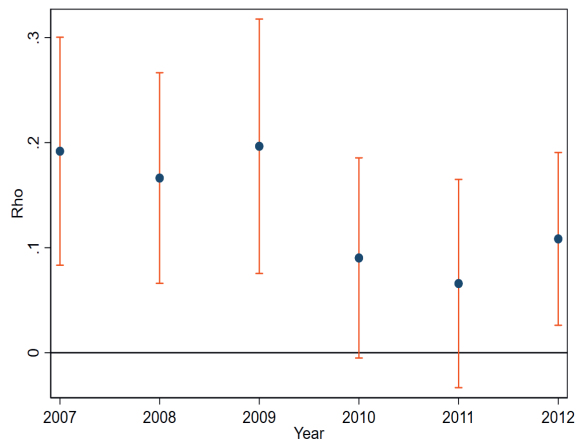

A. Alternatives - First-difference model for common actuaries

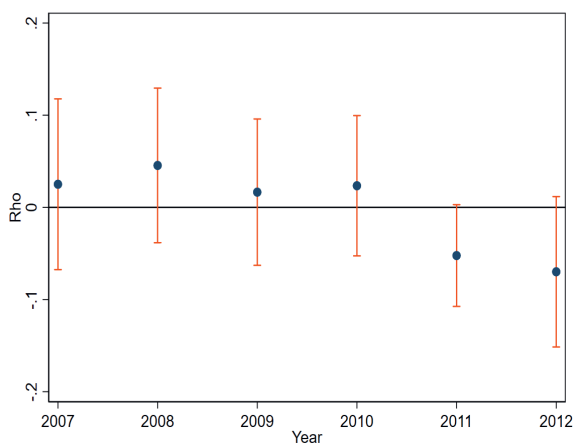

B. Alternatives - First-difference model for overlapping trustees

Notes: The figure shows the estimation results for the spatial panel autoregressive model $\Delta \mathbf{y}_{t}=\rho \mathbf{W} \Delta \mathbf{y}_{t}+\mathbf{X}_{t} \beta+$ $\boldsymbol{\mu}+\boldsymbol{\theta}_{t}+\boldsymbol{\epsilon}_{t}$ (Equation 3.4. The vector of dependent variables $\boldsymbol{\Delta} \mathbf{y}_{t}$ contains the changes in the strategic allocation to alternatives of each pension fund between year $t$ and year $t-1$. The $\mathbf{W}$ is the weighting matrix that equals one when two funds contract the same actuary and zero otherwise in Panel A. In panel B, W is the weighting matrix that equals one when two funds have at least one overlapping trustee. The $\rho$ is the coefficient that captures the spatial correlation among the changes in the SAA of pension funds that contract the same actuary (Panel A) or that have at least one overlapping trustee (Panel B). $\mathbf{X}_{t}$ contains a set of control variables: funding ratio, size, and the liability duration of each pension fund. $\boldsymbol{\mu}$ and $\boldsymbol{\theta}_{t}$ are pension-fund and year fixed effects. The model is estimated every year over the period from 2007-2012 on the subsequent five years.

to alternatives. In line with prior findings there is little evidence of an overlappingtrustee effect on the SAAs.

To summarize, the first-difference analysis provides results that are in line with the analysis performed on the SAAs. Therefore, we reject the hypothesis that the common-advisor effect on the SAAs is driven by spurious correlations among the 
variables in the model 26

\subsection{Conclusion}

We use a unique database on the governance structure and SAAs of 191 Dutch pension funds to study the effect of common asset managers and common actuaries on strategic investment decisions. We investigate whether pension funds are affected by a common-advisor effect. Namely, whether pension funds with the same asset managers or the same actuaries make similar SAA decision over time. We find a strong common-advisor effect. Pension funds with the same asset managers increase or decrease their SAAs to different asset classes in the same year. Pension funds with the same actuaries also increase or decrease their strategic allocations to alternative asset classes in the same year.

Our findings show that asset managers and actuaries transfer their investment beliefs to their clients. On the one hand, we find that pension funds with similar liability structures or similar funding ratios do not make similar investment decisions over time, despite the fact that these pension funds have similar cash flow needs or financial conditions. On the other hand, we find that pension funds that contract the same asset managers or actuaries make similar investment decisions, despite the pension funds' characteristics. Therefore, managers and actuaries' investment beliefs are included in the design of the SAAs with these characteristics. Thus, the commonadvisor effect might lead pension funds to select SAAs that are not in line with their liability structures, funding ratios, sophistication, or organizational structures. Selecting a SAA not in line with a pension fund's sophistication or organizational structure has negative consequences on its performance and cost management. At the same time pension funds may also profit from the knowledge that advisors have about sophisticated asset classes.

\footnotetext{
${ }^{26}$ Supplementary Figures 7 and 8 of the online appendix give the results for the first-difference model that was estimated on each individual alternative asset class.
} 


\section{A Spatial correlation coefficient interpretation}

In this appendix we describe how to quantify the common-advisor effect that occurs among pension funds. The common-advisor effect is measured by the $\rho$ coefficient in a spatial autoregressive model (SAR):

$$
y_{i t}=\rho \sum_{j=1}^{n} W_{i j} y_{j t}+\beta \sum_{k=1}^{K} x_{i t k}+\theta_{t}+\mu_{i}+\epsilon_{i t}
$$

where the spatial autocorrelation coefficient $\rho$ is associated with the following endogenous variable $\sum_{j=1}^{n} W_{i j} y_{j t}$ (the so called spatially lagged variable). The $\sum_{j=1}^{n} W_{i j} y_{j t}$ represents the function of the portfolio allocation of neighboring pension funds in a given asset class at time $t$. Equation (3.5) is equivalent to Equation (3.2). To compute the marginal effect of a change in $y_{j}$ on the value of $y_{i}$ at a given time $t$, we need the partial derivatives of Equation 3.5 with respect to $y_{j}$ :

$$
\frac{\partial y_{i t}}{\partial y_{j t}}=\rho \sum_{j=1}^{n} W_{i j}
$$

All else being equal, the change in the strategic asset allocation of pension fund i $\left(y_{i}\right)$ is a function of the allocation $y$ of neighboring pension funds times $\rho$. For example, consider three pension funds. Their connections are identified by the row standardized weighting matrix $W$ :

$$
W=\left[\begin{array}{lll}
0 & 1 & 0 \\
\frac{1}{2} & 0 & \frac{1}{2} \\
0 & 1 & 0
\end{array}\right]
$$

This equation means that pension funds 1 and 2 are neighbors. Pension fund 2 is a neighbor of pension fund 1 and pension fund 3. Pension fund 3 is a neighbor of pension fund 2. Based on Equation (3.6) we obtain the matrix of partial derivatives: 


$$
\left[\begin{array}{lll}
\frac{\partial y_{1 t}}{\partial y_{1 t}} & \frac{\partial y_{1 t}}{\partial y_{2 t}} & \frac{\partial y_{1 t}}{\partial y_{3 t}} \\
\frac{\partial y_{2 t}}{\partial y_{1 t}} & \frac{\partial y_{2 t} t}{\partial y_{2 t}} & \frac{\partial y_{2 t}}{\partial y_{3 t}} \\
\frac{\partial y_{3 t}}{\partial y_{1 t}} & \frac{\partial y_{3 t}}{\partial y_{2 t}} & \frac{\partial y_{3 t}}{\partial y_{3 t}}
\end{array}\right]=\rho\left[\begin{array}{ccc}
0 & 1 & 0 \\
\frac{1}{2} & 0 & \frac{1}{2} \\
0 & 1 & 0
\end{array}\right]
$$

The results in Table 3.4 show that pension funds with the same asset managers display a $\rho$ coefficient of 0.25 for the strategic allocation to alternatives. If we allow the asset allocation of both pension funds 1 and 3 to increase by 10 percentage points, we can compute the effect on the allocation of pension fund 2, all else being equal, as:

$$
\left[\begin{array}{l}
\Delta y_{1 t} \\
\Delta y_{2 t} \\
\Delta y_{3 t}
\end{array}\right]=0.25\left[\begin{array}{ccc}
0 & 1 & 0 \\
\frac{1}{2} & 0 & \frac{1}{2} \\
0 & 1 & 0
\end{array}\right]\left[\begin{array}{c}
\Delta y_{1 t}=10 \\
\Delta y_{2 t}=? \\
\Delta y_{3 t}=10
\end{array}\right]
$$

Therefore, taking $\Delta y_{1 t}$ and $\Delta y_{3 t}$ as given, $\Delta y_{2 t}$ equals 2.5 percentage points $\left(\Delta y_{2 t}=0.25\left(\frac{10}{2}+\frac{10}{2}\right)\right)$. Namely pension fund 2, a neighbor of pension fund 1 and pension fund 3, will increase its strategic allocation to the alternative asset class by 2.5 percentage points in response to an increase of 10 percentage points in neighboring pension funds, all else being equal.

By contrast, the effects of the independent variables $\beta \sum_{k=1}^{K} x_{i t k}$ on $y_{i t}$ are not only represented by the partial derivatives. Beta coefficients are only part of these derivatives, and the spatial coefficient enters into the calculation. The $\rho$ captures an additional spillover effect via feedback from the spatial lag. For more details on the coefficient interpretation we refer to Chapter 2 of LeSage and Pace (2009). 


\section{Chapter 4}

\section{Pension fund equity performance: Herding does not payoff}

Public equity is one of the main asset classes within the portfolio of any pension fund. Constructing an equity portfolio entails a number of decisions by a pension fund's board of trustees and asset managers that are employed to implement the investment policy. The first decision is the allocation of the equity portfolio across different geographic regions. The second decision is the benchmark selection or the identification of their universe of eligible equity investments (Broeders and De Haan $(2020)$ ). The third decision is to either follow an active or a passive strategy that is defined by how closely a portfolio tracks its benchmark. The fourth and final decision is the security selection or choice of the individual securities to invest in that meet a pension fund's requirements. All these decisions are prone to herding (Lakonishok et al. (1992b)).

In this paper, I examine herding at the security selection level, that is, investors following each other into and out of the same securities over time. Investors may herd because they infer information from each other's trades (Banerjee (1992)), because of common signals (Bauer et al. (2020)), because of homogeneous preferences (Falkenstein (1996), Bennett et al. (2003)), or because they are concerned about underperforming their peers (Scharfstein and Stein (1990)). Herding is a sequential behavior: it starts with an investor that trades a particular security. In the subsequent period, 
another investor trades the same security, in the same direction, by either observing or inferring the trade of the first investor. Less skilled or less informed investors may decide to herd on the trades of first movers. Investors with better skills may instead decide to trade against other investors, that is, anti-herd to exploit their advantage (Jiang and Verardo (2018)).

I study herding in the equity portfolios of Dutch occupational pension funds, and I investigate whether herding influences their performance $\mathrm{I}^{1} \mathrm{I}$ first rely on the herding measure developed by Sias (2004) to test herding among all pension funds. Next, I introduce a pension fund-level measure of herding to test the effect of herding on performance. This measure identifies the extent to which an individual pension fund follows other pension funds. I define a "follower" as a pension fund whose future trades are largely explained by the aggregate trades of other pension funds today.

I show significant herding among pension funds, as the current aggregate demand for securities is positively correlated with the past aggregate demand for the same securities. Next, I show that pension funds that herd ("followers") underperform pension funds that do not herd by $1.32 \%$ on an annual basis. I obtain similar results if I account for pension funds' exposures to global factors such as the market, size, value, and momentum factors. Therefore, the underperformance is not driven by differences in risk exposures. In a multivariate regression, herding negatively predicts four-factor alphas after controlling for pension fund characteristics. Hence, herding negatively affects performance.

The underperformance of followers may be explained by their inability to acquire timely information. Investors that acquire information first, either by chance or by having better skills, can exploit this information to their advantage (Hirshleifer et al. (1994)). Conversely, investors unable to acquire timely information may decide to follow those that do. My results indicate that herding is related to scale, as small pension funds are more likely to be followers. These pension funds may not be able

\footnotetext{
${ }^{1}$ The literature on herding has mainly focused on mutual funds. A number of studies investigate the effect of herding on prices (Wermers (1999), Coval and Stafford (2007), Dasgupta et al. (2011a)). Others, similar to this study, relate herding to fund performance (Grinblatt et al. (1995), Wei et al. (2015).
} 
to select the highest skilled asset managers. Followers also have a lower turnover that indicates they might be unable to trade frequently. Furthermore, followers trade a smaller set of securities that results in a less diversified portfolio.

If herding does not lead to greater performance, why do some pension funds follow others? The rich theoretical foundation for institutional herding distinguishes between information cascades and reputation herding 2 First, models of information cascades posit that investors herd by inferring information from each other (Bikhchandani et al. (1992)). In line with these cascades, I find that pension fund herding is stronger in equity markets with lower analyst coverage, such as small capitalization securities and emerging markets, and thus where learning from other investors can be valuable (Wermers (1999)). Moreover, small pension funds are more likely to be followers, as they generally have less resources to do investment research. Second, the fear of underperforming their peers and concerns about how others will assess their ability to make sound judgments can induce institutional investors to follow each other (Avery and Chevalier (1999), Bikhchandani and Sharma (2000)). In line with this reputational concern, herding appears to be a strategic decision because pension funds consistently herd over time. Pension funds that are categorized as followers in one month tend to also be a follower in subsequent months. Moreover, the fact that small pension funds herd more is also in line with reputation herding. Small pension funds have generally less in-house expertise and therefore tend to delegate more decisions to their asset management firms. Asset management firms have the incentive to retain clients and herding can be a strategy to reduce their responsibility in the event of poor performance. Moreover, it is more efficient for asset management firms to execute the same security selection for different clients.

I perform a number of tests to show that herding does not arise from reasons other than pension funds following each other into and out of the same securities. First, I show that herding does not arise because pension funds hold similar portfolios and decide to invest the periodic contributions in the same securities to keep their portfolio

\footnotetext{
${ }^{2}$ See Graham (1999), Nofsinger and Sias (1999) and Wermers (1999) for a detailed discussion of this classification.
} 
weights constant. Therefore, pension funds do not mechanically herd because of correlated cash flows and similar portfolios. Second, I investigate if herding is driven by pension funds' preferences for securities with certain characteristics, which is in line with style-investing (Barberis and Shleifer (2003)). I find that herding in individual securities persists after controlling for lag returns, market capitalization, and the book-to-market ratio.

The loss of returns related to herding has a direct effect on the funding ratio of a pension fund $\mathrm{I}^{3}$ In the Dutch context, the active participants in a poorly funded pension fund may face an increase in their contribution rate. Furthermore, both the active participants and the retirees may experience a reduction in indexation or even a reduction in accrued pension benefits $4^{4}$ Therefore, participants and retirees bear the costs of herding $5^{5}$ In other jurisdictions, the costs of herding are borne by the stakeholders that bear the underfunding risk. In the case of UK corporate pension funds this is the firm offering the pension plan and in the case of US public pension funds these are the tax payers.

With this study, I contribute to two strands of the literature. First, I contribute to the literature on pension fund performance. A number of studies link this performance to their size and cost efficiency (Bauer et al. (2010), Dyck and Pomorski (2011), Andonov et al. (2012), and Blake et al. (2013)). I concentrate on security selection to show that the low performance of small pension funds is not only related to the lack of economies of scale, but it is also a consequence of herding. Second, I contribute to the empirical literature on herding. Other papers measure herding at the security level as the correlation among institutional investors' demand for the same securities over

\footnotetext{
${ }^{3}$ The ratio of the value of assets over the present value of future liabilities.

${ }^{4}$ Indexation is also known as a cost of living adjustment. The Pension Fund Act in the Netherlands prescribes that this indexation can only be awarded in full if the funding ratio is sufficiently high. In the case when the pension is severely underfunded, accrued pension benefits must be reduced to restore funding.

${ }^{5}$ There is an absence of market discipline in occupational pension funds. It is difficult for participants to leave a pension fund in case of poor investment performance. They can only exit their pension fund by changing jobs and transferring accrued pension benefits from one pension fund to another. This "voting with their feet" would furthermore require finding a job at a firm with a better performing pension fund.
} 
time ${ }^{6}$ I introduce a pension fund-level measure of herding that identifies followers. This measure connects herding to pension fund characteristics such as size, turnover, past returns, and flows.7 Moreover, the findings in this paper show stronger herding compared to earlier evidence of herding among pension funds provided by Lakonishok et al. (1992b). Hence, over time pension funds appear to have developed a stronger tendency to herd in their equity investments.

The remainder of the paper is organized as follows: Section 4.1 introduces the institutional setting and the data used for the study. Section 4.2 shows that pension funds herd as a group. Section 4.3 presents the pension fund-level measure of herding. Section 4.4 investigates the relation between herding and pension fund return. Section 4.5 describes the motivations underlying herding. Section 4.6 addresses alternative explanations for herding. Section 4.7 concludes.

\subsection{Institutional Setting Data}

In this section, I briefly describe the Dutch occupational pension sector. Next, I introduce the institutional ownership data used in this study.

\subsubsection{The institutional setting}

The Dutch pension system consists of the usual three pillars. The first pillar is a state pension available to all citizens in the form of a basic income starting at the statutory age of retirement. The second pillar is the semi-mandatory occupational pensions that are administered by a pension fund or by an insurance company. The Dutch law distinguishes three types of occupational pension funds: industry-wide pension funds,

\footnotetext{
${ }^{6}$ This literature has its origin in Lakonishok et al. (1992b) who developed the first herding measure as the contemporaneous correlation of the demand of pension funds for the same security. Several other studies rely on this measure to investigate institutional herding (Grinblatt et al. (1995), Nofsinger and Sias (1999), and Wermers (1999)). Sias (2004) measures herding as the correlation across institutional demand for a security over adjacent quarters. Dasgupta et al. (2011b) introduces another dynamic security-level measure of herding. These measures better capture the dynamic features of herding. I use Sias (2004) as a baseline model to show that Dutch pension funds herd as a group.

${ }^{7}$ Flows in a pension funds capture the difference between contributions coming in and benefits being paid out.
} 
corporate pension funds, and pension funds for independent professionals. Pension funds are legally and financially independent from the companies. The third pillar consists of individual voluntary pensions. ${ }^{8}$

The Dutch occupational pension funds manage a total of 1,323 billion euros that corresponded to $170 \%$ of the Dutch GDP as of December 2018. The dominant pension contract is a hybrid of defined benefit (DB) and defined contribution (DC). The pension contract is a hybrid because it combines pre-defined benefits calculated on the average income history with solvency-contingent indexation of benefits and contributions (Ponds and Van Riel (2009) ). This structure means that contributions can be raised, indexation stopped, and accrued benefits partially cut in case of severe underfunding of the pension fund. The employer automatically enrolls its employees in the pension fund, and they cannot express individual preferences on the contribution rate or asset allocation, both of which are decided by pension fund's trustees within the boundary of the law $9^{9}$ The trustees employ internal or external asset managers to perform the security selection within different asset classes. Participants cannot leave the pension fund in which they are enrolled unless they switch employers.

Occupational pension funds are particularly suited to investigate herding for a number of reasons. First, pension funds are subject to solvency regulations which can influence their demand for assets with specific characteristics (Greenwood et al. (2018)) 10 Second, pension funds may respond with similar investment strategies to the long-lasting decline in market interest rates that affect the present discounted value of their liabilities (Domanski et al. (2017)). Third, pension funds are a homogeneous group of investors that might share preferences for securities with similar

\footnotetext{
${ }^{8}$ For a summary of the Dutch pension system see OECD (2017). For papers on the features and functioning of the Dutch pension regulation see e.g., Ponds and Van Riel (2009), Cui et al. (2011).

${ }^{9}$ Employers and employees (social partners) negotiate on the features of the pension scheme, e.g. on the accrual rate and indexation target. Next the pension fund determines the contribution that are needed to finance new accruals within the boundaries of the law. If social partners are not willing to pay that contribution, this will imply a lower accrual rate.

${ }^{10}$ In the European Union, 2016 IORP II directive established common standards ensuring the soundness of occupation pension funds. These general standards are then integrated by each member state's regulation. Several studies have shown the effect of regulation on the investment decisions of pension funds Andonov et al. (2017) in the US and Amir et al. (2010) in the UK. Moreover, Boon et al. (2018) show that the difference in regulation can explain the heterogeneity in asset allocations across pension funds in the Netherlands, US, and Canada.
} 
characteristics (Falkenstein (1996), Bennett et al. (2003)). For example, they might follow similar investment styles or favor securities of certain sectors or geographical areas. Fourth, reputational concerns are high among pension funds. Their investment performance is disclosed publicly; this performance faces the scrutiny of pension funds' stakeholders and the board of trustees who can decide to replace the asset manager in case of poor performance ${ }^{11}$ Asset management firms have the incentive to retain their clients and herding can be a strategy to reduce their responsibility in the event of poor performance Scharfstein and Stein (1990). Fifth, the geographical proximity, the social network of pension fund trustees, and common advisors facilitate the transfer of investment beliefs across pension funds (Bauer et al. (2020)).

\subsubsection{Security holding data}

The data for this study are the detailed public equity holdings of Dutch institutional investors who operate in the pension sector. The data are proprietary and provided by the prudential supervisor of pension funds, De Nederlandsche Bank (DNB). The sample consists of the public equity holdings of 44 pension funds and 18 pension asset management firms and correspond to $98 \%$ of the value of all public equity investments for a total of 21,230 unique securities in the Dutch pension fund industry. DNB requires the largest 44 pension funds, that are systematically important, to report monthly their holdings of individual securities. Smaller pension funds are not required to directly report their holdings. However, DNB requires Dutch asset management firms to report the security holdings of all their investment funds larger than 150 million euro. Asset managers must disclose the sector of origin and the shares held by each type of investor in their investment funds. For example, one asset management firm reports that $40 \%$ of the assets of one of their equity funds

\footnotetext{
${ }^{11}$ The performance of mandatory industry-wide pension funds is evaluated against a benchmark. If an industry-wide pension fund underperforms this benchmark for five consecutive years, then the pension fund's stakeholders can contest the mandatory nature of the pension fund. For example, the collective labor agreement in some industries establishes that all companies within the industry must join the industry-wide pension fund set up by the industry organization. Individual companies can contest this mandatory nature and decide to leave if the industry pension fund consistently underperforms its benchmark for five consecutive years.
} 
is owned by pension funds, $40 \%$ by banks, and $20 \%$ by insurance companies. I apply the following procedure to identify the securities managed on behalf of pension funds that are not required to directly report their holdings. First, I isolate all the investment funds in which pension funds hold more than $80 \%$ of the assets every month. Second, I aggregate the holdings of all investment funds managed by the same asset management firm. After this procedure, I am left with the security holdings of 18 asset management firms that manage pension assets. These holdings can be merged with those directly reported by the largest 44 pension funds. The result is a nearly complete picture of the equity investments of pension funds even though not all pension funds are required to report their security holdings. Throughout the paper, I will use the term pension funds for simplicity, even though herding originates from the asset management firm of each pension fund that is the actual decision maker when it comes to security selection.

Each holding is uniquely identified by its International Security Identification Number (ISIN). For each ISIN, the pension funds report the value in euros and the split-adjusted number of securities held at the beginning and at the end of each month as well as the value of the securities bought and sold throughout the month 12 The holding data are merged with security-level information such as price, total returns, market capitalization, and the book-to-market ratio from Factset. The sample comprises international securities. Since the data on holdings are in euros, the securitylevel information is converted to euros. The dataset covers the period from January 2009 to December 2018 for a total of 120 months.

Table 4.1 presents the summary statistics of the holdings data. The average equity portfolio of the pension funds in the sample is 5.7 billion, and the median is 1.1 billion. The standard deviation is high because of a few very large pension funds. During the sample period, pension funds are net buyers of equity, as the value of monthly purchases (227.3 million) is greater than the value of monthly sales $(219.5$ million). The average number of different securities held is 1,464 , and the median is 1,179. Pension funds report an average exposure to European equities of $43 \%$. North

\footnotetext{
${ }^{12}$ I use the split-adjusted number of securities for all the calculations in the paper.
} 
Table 4.1: Summary statistics

\begin{tabular}{lcccccccc}
\hline \hline & Obs. & Mean & Std. Dev. & p5 & p25 & p50 & p75 & p95 \\
\hline Tot. portfolio & 5,736 & $5,772,178$ & $20,012,368$ & 101,796 & 466,856 & $1,143,676$ & $3,204,825$ & $16,447,118$ \\
Purchases & 5,736 & 227,589 & 985,155 & 123.00 & 5,098 & 20,169 & 85,376 & 654049 \\
Sells & 5,736 & 219,932 & 956,622 & 0.00 & 3,854 & 18,086 & 78,498 & 692,453 \\
No. ISIN bought & 5,736 & 238 & 3668 & 2 & 30 & 89 & 279 & 1,042 \\
No. ISIN sold & 5,736 & 210 & 376 & 0 & 18 & 65 & 215 & 1,003 \\
No. ISIN held & 5,736 & 1,464 & 1,372 & 102 & 340 & 1,178 & 2,053 & 4,162 \\
Share Europe & 5,736 & 0.4318 & 0.2395 & 0.1125 & 0.2706 & 0.3744 & 0.5290 & 0.9589 \\
Share North America & 5,736 & 0.3209 & 0.1770 & 0.0000 & 0.2222 & 0.3674 & 0.4453 & 0.5762 \\
Share Asia \& Pacific & 5,736 & 0.1166 & 0.1372 & 0.0000 & 0.0494 & 0.1082 & 0.1433 & 0.2358 \\
Share developed & 5,736 & 0.8693 & 0.1604 & 0.6148 & 0.8026 & 0.9349 & 0.9777 & 0.9925 \\
Share emerging & 5,736 & 0.1294 & 0.1603 & 0.0066 & 0.0215 & 0.0627 & 0.1958 & 0.3841 \\
Monthly return & 5,736 & 0.0111 & 0.0328 & -0.0454 & -0.0069 & 0.0113 & 0.0315 & 0.0675 \\
Turnover & 5,736 & 0.0228 & 0.1346 & 0.0002 & 0.0020 & 0.0059 & 0.0175 & 0.0806 \\
Flow & 5,736 & 0.0004 & 0.1442 & -0.0545 & -0.0077 & -0.0015 & 0.0051 & 0.0444 \\
\hline \hline
\end{tabular}

Notes: This table presents the time-series and cross-sectional mean, median, standard deviation, $5^{\text {th }}, 25^{\text {th }}, 75^{\text {th }}$, and $95^{\text {th }}$ percentile of the public equity portfolio characteristics of pension funds. The portfolio characteristics are the value of total purchases and sells during each month in thousands of euros; the total equity portfolio at end of each month in thousands of euros; the number of individual securities (ISINs) purchased or sold during the month; the total number of individual securities (ISINs) held at the beginning of each month; the share of the equity portfolio invested in each geographical area; the monthly portfolio return (value weighted); and the turnover ratio and flows. Data are for the January 2008 to December 2018 period.

American (US and Canada) securities account for $32 \%$ of the portfolio, Asian and Pacific $12 \%$, and emerging markets account for $13 \%{ }^{[3}$ Over the sample period, the average monthly gross portfolio return is $1.1 \%$. Pension fund returns are computed using the Dietz (1966) method:

$$
R_{n, j, t}=\frac{V_{n, j, t}-\operatorname{Trade}_{n, j, t}-E X_{n, j, t}-V_{n, j, t-1}}{V_{n, j, t-1} * 0.5\left(\operatorname{Trade}_{n, j, t}\right)}
$$

where $V_{n, j, t}$ is the value of the position in security $j$ of pension fund $n$ in month $t$. Trade $_{n, j, t}$ represents the net value of security $j$ traded by pension fund $n$ during month $t$ : total purchases minus total sells. $E X_{n, j, t}$ is the change in the value of the position in $j$ due to exchange rate changes. $V_{n, j, t-1}$ is the value of the position in security $j$ of pension fund $n$ in month $t-1$, which corresponds to the value of the position at the beginning of month $t$. By multiplying Trade $e_{n, j, t}$ times 0.5 in the denominator, I assume that transactions are on average executed halfway through the month. $R_{n, j, t}$ is therefore the return on the position in each security. Pension funds' total returns are computed as the weighted average of the returns on each position, where weights

\footnotetext{
${ }^{13}$ I classify developed countries as in Fama and French (2012); all the countries that are not classified as developed are then classified as emerging economies.
} 
are the share of each security in the pension fund's portfolio.

Pension funds report an average turnover ratio of $2 \%$ (median $0.6 \%$ ) and an average flow of $0.04 \%$ (median $-0.02 \%$ ). The pension fund turnover ratio is the absolute value of the ratio between net purchases at the end of a month and the portfolio value at the beginning of the month (see, e.g., Brennan and Cao (1997)). In line with Sialm et al. (2015), pension fund flows are defined as the incremental value of a pension fund's portfolio at the end of a month that is not due to portfolio returns over that month. Pension fund flows are driven by cash flows from contributions coming in and benefit payments going out. Moreover, flows can capture the heterogeneity in pension funds' strategic asset allocations. For example, if a pension fund's board of trustees decides to increase the strategic allocation to fixed-income securities, this increase will translate into an outflow from the equity portfolio.

\subsection{Pension funds' herding}

In this section, I show that Dutch pension funds, as a group, follow each other into and out of the same securities over time by relying on the aggregate measure of herding introduced by Sias $(2004)$.

\subsubsection{Aggregate pension funds demand}

Each month, I classify a pension fund as a buyer if the number of securities held at the end of the month is greater than the number of securities held at the beginning. A pension fund is a seller if the number of securities held at the end of the month is smaller than the number of securities held at the beginning. A pension fund is classified as a trader, if it is either a buyer or a seller. If the number of securities is the same at the beginning and end of the month, the pension fund is classified as neither a buyer nor a seller. Also, a pension fund that buys and sells the same number of securities within a month is classified as neither a buyer nor a seller. For each month, I calculate the raw fraction of pension funds that buy security $j$ during month $t$ : 


$$
\operatorname{Raw} \Delta_{j, t}=\frac{\text { No. of Pension funds buying }, t}{\text { No. of Pension funds buying }}
$$

I exclude the initiation and liquidation of a position. Namely, I exclude securities that are purchased for the first time by a pension fund and securities that disappear from the pension fund's portfolio in a given month.

Table 4.2 presents the average number of securities with at least $1,3,5$, or 10 pension funds trading it over the 120 months in the sample, and the total number of securities traded in different time periods. The first column shows that on average there are 4,837 securities that are traded by at least 1 pension fund each month, 2,246 securities traded by at least $3,1,397$ securities traded by at least 5 , and 428 securities traded by at least 10 pension funds. These numbers are quite stable over time as shown by the following columns. The average number of securities each year is 9,663 meaning that roughly half of the securities in the sample are not traded every month. However, there is a number of securities that are often traded by several pension funds.

Table 4.2: Number of securities traded by pension funds over time

\begin{tabular}{lcccccc}
\hline \hline & $\begin{array}{c}\text { Avg. } \\
\text { all periods }\end{array}$ & $\begin{array}{c}\text { Jan. } \\
2009\end{array}$ & $\begin{array}{c}\text { Jun. } \\
2011\end{array}$ & $\begin{array}{c}\text { Dec. } \\
2013\end{array}$ & $\begin{array}{c}\text { Jun. } \\
2016\end{array}$ & $\begin{array}{c}\text { Dec. } \\
2018\end{array}$ \\
\hline Panel A: No. of securities with & & & & & & \\
$\geq 1$ pension fund trading & 4,837 & 4,611 & 4,579 & 4,352 & 5,126 & 4,742 \\
$\geq 3$ pension funds trading & 2,246 & 1,970 & 2,017 & 1,838 & 2,502 & 2,159 \\
$\geq 5$ pension funds trading & 1,397 & 1,136 & 1,216 & 962 & 1,637 & 1,372 \\
$\geq 10$ pension funds trading & 428 & 362 & 366 & 205 & 592 & 483 \\
\hline Panel B: No. of securities in the sample & 9,663 & 8,843 & 8,150 & 9,107 & 10,458 & 11,703 \\
\hline \hline
\end{tabular}

Notes: For each security and month between January 2009 and December 2018, I compute the number of pension funds that trade the security. Pension funds are defined as traders if they hold either a greater or smaller number of split-adjusted securities at the end of the month than they held at the beginning. If a pension fund holds the same number of split-adjusted securities at the end of the month as it held at the beginning, it is not classified as a trader. Also, a pension fund is not classified as a trader, if it buys and sells the same number of split-adjusted securities during the month. The first column of Panel A presents the time-series average of the number of securities with at least $1,3,5$ or 10 pension funds trading over the 120 months in the sample. The next columns show the number of securities with at least 1, 3, 5 or 10 pension funds trading them in January 2009, June 2011, December 2013, June 2016, and December 2018. These dates are chosen to be able to compare equal time windows. 


\subsubsection{Aggregate herding measure}

As several pension funds trade a lot the same securities, it is important to establish if herding is driving these trades. To measure pension fund herding in the same securities, I first standardize the raw fraction of pension funds that buy (standardized pension fund demand) in the following way:

$$
\Delta_{j, t}=\frac{R a w \Delta_{j, t}-\overline{\operatorname{Raw} \Delta_{t}}}{\sigma\left(\operatorname{Raw} \Delta_{j, t}\right)}
$$

where $\overline{\operatorname{Raw} \Delta_{t}}$ is the cross-sectional average (across $J$ securities) raw fraction of pension funds that buy in month $t$, and $\sigma\left(\operatorname{Raw} \Delta_{j, t}\right)$ is the cross-sectional standard deviation (across $J$ securities) of the raw fraction of pension funds that buy in month t. Second, for each month I estimate a cross-sectional (across $J$ securities) regression of the standardized fraction of pension funds that buy security $j$ in the current month, on the standardized fraction of pension funds that buy security $j$ in the previous month. In other words, I regress the standardized demand for security $j$ on the standardized lag demand for security $\mathrm{j}$ :

$$
\Delta_{j, t}=\beta_{t} \Delta_{j, t-1}+\epsilon_{j, t}
$$

Because the data are standardized and there is only one independent variable, the coefficients for each cross-sectional regression in Equation 4.4 can be interpreted as the correlation between the standardized demand for security $j\left(\Delta_{j, t}\right)$ and the standardized lag demand for security $j\left(\Delta_{j, t-1}\right){ }^{14}$ A positive correlation between the pension fund demand and the pension fund lag demand can occur because pension funds follow themselves or because pension funds follow each other into and out of the same security over subsequent months; that is, they herd. Thus, the correlation between the demand this month and the demand last month can be decomposed

\footnotetext{
${ }^{14}$ The standardization of the data is necessary to interpret the coefficient in Equation 4.4 as a correlation. Then, I can split the correlation coefficient into two terms as described in Equation 4.5. Moreover, the standardization makes possible the aggregation of the coefficients over time to directly compare them. Each regression coefficient depends on the scale of the data, if the pension funds' demand was not standardized, then the comparison of different cross-sectional regression coefficients would be inappropriate.
} 
into the portion that results from pension funds following themselves into and out of the same security over subsequent months and the portion that results from pension funds following each other into and out of the same security. Specifically, the fraction of pension funds that are buyers can be written as the sum of a series of dummy variables for each pension fund that equal one if the pension fund is a buyer and zero if it is a seller divided by the number of pension funds that are either buyers or sellers. As a result, the $\beta$ coefficient in Equation 4.4 can be rewritten as: ${ }^{15}$

$$
\begin{array}{r}
\beta_{t}=\rho\left(\Delta_{j, t}, \Delta_{j, t-1}\right)=\left[\frac{1}{(J-1) \sigma\left(\operatorname{Raw} \Delta_{j, t}\right) \sigma\left(\operatorname{Raw} \Delta_{j, t-1}\right)}\right] \\
\times \sum_{j=1}^{J}\left[\sum_{n=1}^{N_{j, t}} \frac{\left(d_{n, j, t}-\overline{\operatorname{Raw} \Delta_{t}}\right)\left(d_{n, j, t-1}-\overline{\operatorname{Raw} \Delta_{t-1}}\right)}{N_{j, t} N_{j, t-1}}\right] \\
+\left[\frac{1}{(J-1) \sigma\left(\operatorname{Raw} \Delta_{j, t}\right) \sigma\left(\operatorname{Raw} \Delta_{j, t-1}\right)}\right] \\
\times \sum_{j=1}^{J}\left[\sum_{n=1}^{N_{j, t}} \sum_{m=1, m \neq n}^{N_{j, t-1}} \frac{\left(d_{n, j, t}-\overline{R a w \Delta_{t}}\right)\left(d_{m, j, t-1}-\overline{\operatorname{Raw} \Delta_{t-1}}\right)}{N_{j, t} N_{j, t-1}}\right]
\end{array}
$$

where $N_{j, t}$ is the number of pension funds trading security $j$ in month $t$, and $d_{n, j, t}$ is a dummy variable that equals one (zero) if pension fund $n$ buys (sells) security $j$ in month $t . N_{j, t-1}$ is the number of pension funds trading security $j$ in month $t-1, d_{n, j, t-1}$ is a dummy variable that equals one (zero) if pension fund $n$ buys (sells) security $j$ in month $t-1$, and $d_{m, j, t-1}$ is a dummy variable that equals one (zero) if pension fund $m(m \neq n)$ buys (sells) security $j$ in month $t-1$.

The first term in the right-hand side of Equation 4.5 is the portion of the correlation that results from pension funds following themselves into and out of the same securities over subsequent months. The second term in the right-hand side of Equation 4.5 is the portion of the correlation that results from pension funds following each other into and out of the same securities over subsequent months. The first term will be positive if pension fund $n$ buys security $j$ in month $t-1$ and $t$ or sells security $j$ in both months. The second term will be positive if pension fund $n$ buys (sell)

\footnotetext{
${ }^{15}$ For the proof see $\operatorname{Sias}(2004)$.
} 
security $j$ in month $t$ and pension fund $m$ buys (sell) security $j$ in month $t-1$. The second term will be negative if pension fund $n$ buys (sells) security $j$ in month $t$ and if pension fund $m$ sells (buys) security $j$ in month $t-1$. In that case, pension funds display anti-herding behavior. If the demand of pension fund $n$ is not correlated with the lag demand of pension fund $m$, then the second term is zero, that is, pension funds do not herd.

Table 4.3: Aggregate herding measure

\begin{tabular}{lcccc}
\hline \hline & $\begin{array}{c}\text { Time-series } \\
\text { avg. } \beta \text { coeff. }\end{array}$ & $\begin{array}{c}\text { Pf. following } \\
\text { their own trades }\end{array}$ & $\begin{array}{c}\text { Pf. following } \\
\text { others' trades }\end{array}$ & Avg. $R^{2}$ \\
\hline Panel A: Securities with & $\begin{array}{c}0.1973^{* * *} \\
(33.38)\end{array}$ & $\begin{array}{c}0.0969^{* * *} \\
(33.57)\end{array}$ & $\begin{array}{c}0.1004^{* * *} \\
(18.18)\end{array}$ & $\begin{array}{c}0.0431^{* * *} \\
(18.87)\end{array}$ \\
$\geq 3$ pension funds trading & & & & \\
& $0.1949^{* * *}$ & $0.0818^{* * *}$ & $0.1131^{* * *}$ & $0.0431^{* * *}$ \\
Panel B: Securities with & $(29.44)$ & $(26.24)$ & $(16.82)$ & $(16.79)$ \\
$\geq 5$ pension funds trading & & & & \\
& $0.1996^{* * *}$ & $0.0674^{* * *}$ & $0.1322^{* * *}$ & $0.0499^{* * *}$ \\
Panel C: Securities with & $(21.55)$ & $(16.96)$ & $(14.04)$ & $(12.34)$ \\
$\geq 10$ pension funds trading & & & &
\end{tabular}

Notes: For each security and month between January 2009 and December 2018, I compute the fraction of pension funds (Pf) that increase their position in the security, as in Equation 4.2. Pension funds are defined as increasing their position (buyers) if they hold a greater number of split-adjusted securities at the end of the month than they held at the beginning. I standardize both the fraction of pension funds that buy and the lag fraction of pension funds that buy to have a zero mean and a unit variance. I estimate 119 monthly cross-sectional regressions of the fraction of pension funds that buy on the lag fraction of pension funds that buy, as in Equation 4.4. Because there is a single independent variable in each regression and all data are standardized, the regression coefficients can be interpreted as a correlation. The first column presents the time-series average of 119 correlation coefficients and the associated t-statistics in parentheses. The t-statistics are computed from the time-series standard errors. The second and third column give the portion of the correlations that results from pension funds following their own traders and the portion of the correlations that results from pension funds following other pension funds' trades, that is, herding as described in Equation 4.5 . The fourth column shows the time-series average of the $R^{2}$ of the 119 cross-sectional regressions. Panels $\mathrm{A}, \mathrm{B}$, and $\mathrm{C}$ show the average coefficients when limiting the sample to securities with at least 3 , 5 , or 10 traders. The $*$ indicates statistical significance at the $10 \%$ level, ${ }^{* *}$ at $\%$ the 5 percent, and ${ }^{* * *}$ at the $1 \%$ level.

I find significant herding among pension funds as a group. Table 4.3 presents the time-series average coefficients from 119 cross-sectional regressions described by Equation 4.4 and the coefficient decomposition described by Equation 4.5. Panels $\mathrm{A}, \mathrm{B}$, and $\mathrm{C}$ show strong statistical evidence that pension funds follow themselves and each other into and out of the same securities. For securities with at least 3 trading pension funds, the correlation coefficient between the standardized fraction of pension funds that buy and the standardized lag fraction of pension funds that buy is $0.19733^{16}$ On average, $51 \%$ of the correlation, $0.1004 / 0.1973$, results from

\footnotetext{
${ }^{16}$ The standardization has little effect on the regression coefficient in Equation 4.4. Using the raw data instead of the standardized data, the slope coefficient is 0.1806 (t-statistic $=30.32$ ) when limiting the sample to securities in more than 3 trading pension funds. The slope coefficient is 0.1830
} 
pension funds herding. The remaining fraction of the correlation, 0.0969/0.1973, results from pension funds following themselves into and out of the same securities, that is, spreading their trades over subsequent months. The results for the sample of securities with at least 5 and 10 trading funds also show that pension funds herd and spread their trades over subsequent months ${ }^{17}{ }^{18}$ The remainder of the analysis will be carried out on the sample of securities with at least three traders. This choice is motivated by the fact that on the one hand, I am interested in identifying the determinants of herding and therefore a minimum number of traders in each security is necessary to study such a behavior. On the other hand, I am interested in linking herding to performance, therefore I want to have a realistic representation of the portfolios of the pension funds in the sample.

\subsection{Pension fund-level measure of herding}

Theoretical models of herding depict it as a dynamic behavior in which an agent infers information from the actions of others (Scharfstein and Stein 1990), Banerjee (1992)). Empirical studies measure herding among institutional investors as the correlation among investors' demands for the same security in the same period (Lakonishok et al. (1992b)), or as the correlation of the aggregate institutional demand over adjacent periods (Sias (2004) ). However, these measures do not completely capture the dynamics of the sequential decisions of institutional investors because they measure herding at the security level. Hence, they capture the extent to which investors, as a group, buy or sell the same securities over time. However, herding occurs after an

$(\mathrm{t}$-statistic $=26.80)$ when limiting the sample to securities in more than 5 trading pension funds, and 0.1990 (t-statistic $=20.10)$ when limiting the sample to securities in more than 10 trading pension funds.

${ }^{17}$ In unreported results, I show that the fraction of the correlation that results from herding is 0.0503 for the sample that includes all securities traded. This finding is due to the fact that each month, there are a number of securities that are traded by only one pension fund for which the second component is by definition zero. This trading reduces the portion of the correlation due to herding. Details are available on request.

${ }^{18}$ In unreported results, I show that the results are unchanged, if I estimate Equation 4.4 and Equation 4.5 by excluding the securities of Dutch firms. Therefore, herding is not driven by home bias or political pressure that might affect asset managers' investment decisions (Bradley et al. (2016), Andonov et al. (2018a)). Details are available on request. 
agent provides a first piece of information through an action to another, which action in turn is replicated. To better capture this sequential nature, and to understand the drivers of herding, I develop a measure that identifies the extent to which a pension fund follows other pension funds into and out of the same securities over time. I define a "follower" as a pension fund whose future trades are largely explained by the aggregate trades of other pension funds today. In the mutual fund literature, a similar herding measure was developed by Jiang and Verardo (2018).

To identify followers, I estimate the contribution of all other pension funds' current demand in explaining each pension fund's future demand. Specifically, for each pension fund $n$, I run a cross-sectional (across $J$ securities) regression of the demand for security $j$ of pension fund $n$ in month $t$ on the lag demand for security $j$ of all other pension funds except for pension fund $n$ itself:

$$
D_{n, j, t}=\alpha_{j, t}+\beta_{1} D_{N, j, t-1}^{n}+\epsilon_{j, t}
$$

where $D_{n, j, t}$ is the change in the number of securities $j$ in the portfolio of pension fund $n$ during month $t$ that are scaled by the number of securities held at the end of month $t-1: D_{n, j, t}=\left(\right.$ No.Shares $_{n, j, t}-$ No.Shares $\left._{n, j, t-1}\right) /$ No.Shares $_{n, j, t-1} . D_{N, j, t-1}^{n}$ is the change in the number of securities $j$ in the portfolio of all pension funds other than pension fund $n$ during month $t-1$ :

$D_{N, j, t-1}^{n}=\frac{\left(\text { No. }_{\left.\text {Shares }_{N, j, t-1}-\text { No.Shares }_{n, j, t-1}\right)-\left(\text { No.Shares }_{N, j, t-2}-\text { No. }_{\text {Shares }}, j, t-2\right.}\right)}{\left(\text { No.Shares }_{N, j, t-2}-\text { No.Shares }_{n, j, t-2}\right)}$

where No.Shares $_{N, j, t-1}$ is the total number of securities $j$ in the portfolio of all pension funds in month $t-1$. Therefore, Equation 4.7 is the change in the aggregate ownership of pension funds, except $n$, of security $j$ during month $t-1$.

I estimate Equation (4.6) for each pension fund $n$ for each month $t$. The regression $R^{2}$ of Equation $4.6, R_{n, t}^{2}$, is the fraction of variation in pension fund $n$ 's demand at time $t$ that is explained by the demand of all other pension funds. This is a measure 
of herding of pension fund $n$. The greater $R_{n, t}^{2}$, the more the aggregate demand of other pension funds explains the future demand of pension fund $n$; that is, the more pension fund $n$ follows the demand of other pension funds.

\subsection{Herding and portfolio performance}

In this section, after having measured herding for each pension fund, I examine the relation between herding and gross portfolio returns to investigate if follower pension funds can profit from herding. I begin with a univariate portfolio test to link herding to portfolio returns. Then, I study if the relation between herding and performance persists over time. Next, I estimate predictive regressions of pension fund performance that control for multiple pension fund characteristics to examine if herding can predict future performance.

\subsubsection{Follower pension funds' portfolio performance}

Do follower pension funds profit from herding? To address this question, I identify the pension funds that herd the most, and I compare their performance with the performance of pension funds that do not herd. Panel A of Table 4.4 presents the summary statistics of the herding measure: $R_{n, t}^{2}$. These statistics are computed crosssectionally each month and then averaged over 119 months. The mean of $R_{n, t}^{2}$ is $4 \%$ which indicates that on average the lag demand of all other pension funds explains $4 \%$ of the variation in each pension fund's demand. The standard deviation is $12.69 \%$ that indicates high variability in the herding measure. In fact, the 5 th percentile is $0 \%$ that indicates no herding, while the 95 th percentile is $18.27 \%$ that indicates strong herding.

In panel B, I use a portfolio-based analysis to examine the difference in performance between follower and non-follower pension funds. At the end of each month, I sort pension funds into five portfolios based on the estimated $R_{n, t}^{2}$. Next, I compute equally weighted returns for each quintile portfolio over the next month and the next quarter. Figure 4-1 shows a graphical representation of the portfolio formation 


\section{Table 4.4: Follower pension funds and portfolio performance}

\begin{tabular}{|c|c|c|c|c|c|c|}
\hline & \multicolumn{6}{|c|}{ Panel A: Summary statistics of the follower pension funds measure } \\
\hline & mean & $\mathrm{sd}$ & $\mathrm{p} 5$ & $\mathrm{p} 25$ & p75 & p95 \\
\hline \multirow[t]{2}{*}{$R_{n, t}^{2}$} & 0.0401 & 0.1269 & 0.0000 & 0.0008 & 0.0193 & 0.1827 \\
\hline & \multicolumn{6}{|c|}{ Panel B: Follower pension funds and portfolio performance } \\
\hline Quintile & $(1)$ & $(2)$ & (3) & (4) & (5) & $5-1$ \\
\hline \multirow[t]{2}{*}{ Avg. $R_{t}^{2}$} & 0.0002 & 0.0015 & 0.0052 & 0.0174 & 0.1843 & 0.1840 \\
\hline & \multicolumn{6}{|c|}{ Return month $t+1$ (\%) } \\
\hline Average & $\begin{array}{c}1.1756^{* * *} \\
(4.10)\end{array}$ & $\begin{array}{c}1.1175^{* * *} \\
(3.86)\end{array}$ & $\begin{array}{c}1.0996^{* * *} \\
(3.80)\end{array}$ & $\begin{array}{c}1.1203^{* * *} \\
(3.78)\end{array}$ & $\begin{array}{c}1.0624^{* * *} \\
(3.82)\end{array}$ & $\begin{array}{c}-0.1132^{* *} \\
(-2.38)\end{array}$ \\
\hline $\mathrm{CAPM} \alpha_{M S C I}$ & $\begin{array}{l}0.0683 \\
(0.95)\end{array}$ & $\begin{array}{r}0.0136 \\
(0.18)\end{array}$ & $\begin{array}{c}-0.0210 \\
(-0.29)\end{array}$ & $\begin{array}{l}0.0035 \\
(0.05)\end{array}$ & $\begin{array}{c}-0.0489 \\
(-0.57)\end{array}$ & $\begin{array}{c}-0.1172^{* *} \\
(-2.27)\end{array}$ \\
\hline G4F $\alpha$ & $\begin{array}{l}0.1458 \\
(1.27)\end{array}$ & $\begin{array}{l}0.0732 \\
(0.59)\end{array}$ & $\begin{array}{l}0.0416 \\
(0.35)\end{array}$ & $\begin{array}{l}0.0632 \\
(0.49)\end{array}$ & $\begin{array}{c}0.0474 \\
(0.38)\end{array}$ & $\begin{array}{c}-0.0985^{*} \\
(-1.98)\end{array}$ \\
\hline \multirow[t]{2}{*}{ NA3F $\alpha$} & $\begin{array}{r}-0.1350 \\
(-0.66) \\
\end{array}$ & $\begin{array}{c}-0.1904 \\
(-0.88) \\
\end{array}$ & $\begin{array}{r}-0.2311 \\
(-1.11) \\
\end{array}$ & $\begin{array}{c}-0.2095 \\
(-0.96) \\
\end{array}$ & $\begin{array}{r}-0.2351 \\
(-1.14) \\
\end{array}$ & $\begin{array}{c}-0.1001^{* *} \\
(-2.01) \\
\end{array}$ \\
\hline & \multicolumn{6}{|c|}{ Return month $t+3(\%)$} \\
\hline Average & $\begin{array}{c}3.5990^{* * *} \\
(4.65)\end{array}$ & $\begin{array}{c}3.6001^{* * *} \\
(4.79)\end{array}$ & $\begin{array}{c}3.5860^{* * *} \\
(4.75)\end{array}$ & $\begin{array}{c}3.4780^{* * *} \\
(4.55)\end{array}$ & $\begin{array}{c}3.3830^{* * *} \\
(4.60)\end{array}$ & $\begin{array}{c}-0.2159^{* *} \\
(-2.08)\end{array}$ \\
\hline $\mathrm{CAPM} \alpha_{M S C I}$ & $\begin{array}{c}0.3621^{* *} \\
(1.98)\end{array}$ & $\begin{array}{c}0.4523^{* *} \\
(2.45)\end{array}$ & $\begin{array}{c}0.4253^{* *} \\
(2.22)\end{array}$ & $\begin{array}{l}0.2905 \\
(1.57)\end{array}$ & $\begin{array}{l}0.2348 \\
(1.09)\end{array}$ & $\begin{array}{c}-0.1273 \\
(-1.24)\end{array}$ \\
\hline G4F $\alpha$ & $\begin{array}{l}0.2720 \\
(1.04)\end{array}$ & $\begin{array}{c}0.3102 \\
(1.15)\end{array}$ & $\begin{array}{c}0.1962 \\
(0.69)\end{array}$ & $\begin{array}{l}0.1660 \\
(0.62)\end{array}$ & $\begin{array}{c}0.2510 \\
(0.91)\end{array}$ & $\begin{array}{l}-0.0210 \\
(-0.22)\end{array}$ \\
\hline NA3F $\alpha$ & $\begin{array}{c}-0.7251 \\
(-1.20) \\
\end{array}$ & $\begin{array}{r}-0.6022 \\
(-0.99) \\
\end{array}$ & $\begin{array}{r}-0.6828 \\
(-1.14) \\
\end{array}$ & $\begin{array}{c}-0.7699 \\
(-1.25) \\
\end{array}$ & $\begin{array}{r}-0.6827 \\
(-1.12) \\
\end{array}$ & $\begin{array}{l}0.0424 \\
(0.42) \\
\end{array}$ \\
\hline
\end{tabular}

Notes: In Panel A, I present the summary statistics of $R_{n, t}^{2}$ : the indicator of the power of all other pension funds' demand in predicting pension fund $n$ 's demand that is estimated following the steps outlined in Section 4.3 Pension funds with a high $R_{n, t}^{2}$ are defined as follower pension funds. Panel B presents the performance of quintile portfolios of pension funds based on $R_{n, t}^{2}$. The quintile portfolios are formed at the end of each month from February 2009 to December 2018 and held for one or three months. I report equally weighted returns for each quintile portfolio over the next month and quarter (cumulative three-month returns). Quintile 5 is the portfolio of follower pension funds. Quintile 1 is the portfolio of non-followers. I also estimate the risk-adjusted returns based on the CAPM and the Fama and French (2012) global market size, value, and momentum factors (G4F) as well as North-American market, size and value factors (NA3F) in three separate regressions. The risk-adjusted returns are the intercept from a time-series regression of the quintile portfolios excess returns over the US one-month T-bill rate on the risk factors. The CAPM market return is given by the monthly total return on the MSCI All Country World Index. For the timeseries regression on North-American factors, the market risk premium is the return on the region's value-weighted market portfolio minus the US one-month T-bill rate. All factors are converted into euro returns. The t-statistics are in parentheses and are computed using Newey-West standard errors with three lags. The * indicates statistical significance at the $10 \%$ level, ${ }^{* *}$ at the $\% 5$ percent, and ${ }^{* * *}$ at the $1 \%$ level.

methodology. Then, I estimate the risk-adjusted excess returns of these portfolios as intercepts from time-series regressions on the capital asset pricing model (CAPM) and the global three-factor model of Fama and French (2012) that is augmented with the global momentum factor ${ }^{19}$ To account for the fact that pension funds hold a sizable portion of their equity portfolio in North American securities, and that the US stock market has outperformed global indices during the sample period, I also

\footnotetext{
${ }^{19}$ Since the dataset includes international security holdings, I use the monthly total returns on the MSCI All Country World Index (ACWI) as the market return to compute the CAPM alphas. The global market return, size, value, and momentum factors, as well as the North American risk factors, are retrieved from Kenneth French's website: https://mba.tuck.dartmouth.edu/pages /faculty/ken.french/
} 


\section{Figure 4-1. Portfolio formation methodology}

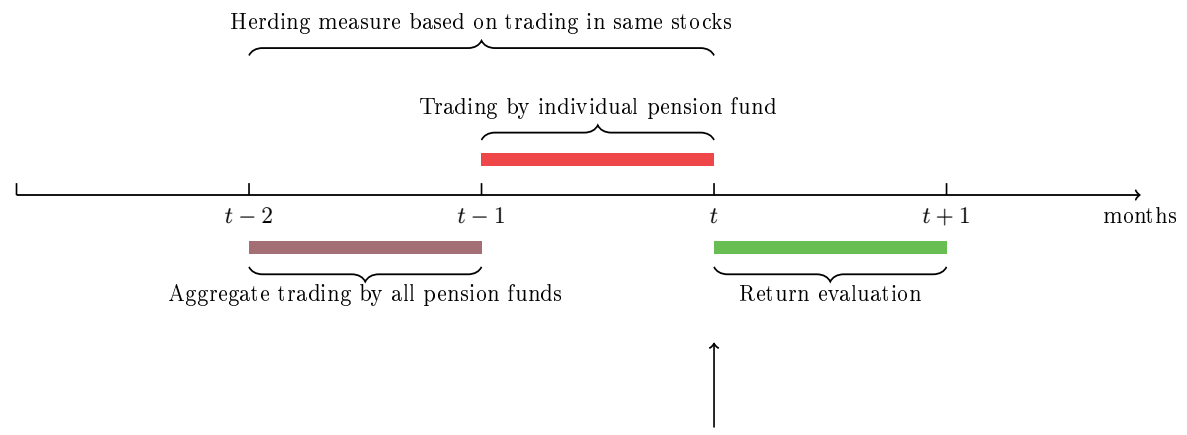

Follower identification and portfolio formation

Notes: The figure shows the timeline of the methodologies used to capture herding and then assess the returns of pension funds based on their tendency to herd. First, I measure herding at the end of each month (from $t-1$ to $t$ ) by relating the trades of a pension with the trades of all other pension funds in the previous month (from $t-2$ to $t-1$ ). Second, I form portfolios based on the herding measure $R_{n, t}^{2}$. Third, I assess the next-month returns of the pension fund portfolios that are formed based on quintiles of $R_{n, t}^{2}$ at the end of month $t$.

estimate the risk-adjusted returns on the North American market risk premium, size, and value factors. As the risk-free rate, I use the US one-month T-bill rate in all specifications.

In the top row of Panel $\mathrm{B}$, I summarize the average $R_{n, t}^{2}$ in each quintile. Pension funds in the top quintile are followers (column 5). Non-followers are included in the bottom quintile portfolio (column 1). The results show that in the month following portfolio formation, the pension funds with the highest herding tendency underperform the pension funds with the lowest herding tendency by $0.11 \%$ per month. This is equivalent to a return differential of $1.32 \%$ per year ${ }^{20}$ The performance difference between follower and non-follower pension funds cannot be attributed to differences in factor risk exposure, as the differences in alphas from the CAPM, the Global 4-factor model, and the North American 3-factor model are: $-0.12 \%,-0.10 \%$, and $-0.10 \%$, and are statistically significant.Three months after portfolio formation the quintile portfolio of follower pension funds underperforms the quintile portfolio of non-follower pension funds by $0.22 \%$. However, the difference disappears after correcting for risk

\footnotetext{
${ }^{20}$ Note that the estimated underperformance of $1.32 \%$ per year has large standard errors. The hypothesis that the underperformance is null can only be rejected at conventional significance levels. The large standard errors are due to the small cross-section (62 institutions). The quintile analysis presented in Table 4.4 further splits the sample, and as a result the average monthly return computed in each quintile comes from no more than 12 pension funds.
} 
factors. This disappearance indicates that over a quarter, pension funds that herd more are exposed to the same risk factors as pension funds that herd less.

In Section 4.A.1 of the appendix, I replicate the quintile portfolio analysis across different security characteristics. In markets less covered by analysts, the incentive and potential benefits of herding can be higher for less skilled or poorly informed pension funds (Wermers (1999)). I compute quintile portfolios based on $R_{n, t}^{2}$ in small capitalization securities as opposed to large capitalization securities, and in emerging market securities as opposed to developed market securities. Table 4.11 shows that pension funds herd more in small capitalization securities than large ones, as the average $R_{n, t}^{2}$ in each quintile is larger when limiting the sample to small securities (Panel A) than when limiting the sample to large securities (Panel B). Follower pension funds slightly underperform non-follower pension funds in both small and large capitalization securities. However, the difference is not statistically significant: ${ }^{21}$ Table 4.12 shows that pension funds herd more in emerging markets than in developed markets, as the average $R_{n, t}^{2}$ in each quintile is larger in the sample of emerging-market securities (Panel B) than in the sample of developed-country securities (Panel A). Moreover, follower pension funds underperform non-follower pension funds by $0.12 \%$ in developed markets and by $0.23 \%$ in emerging markets that corresponds to $2.76 \%$ on an annualized basis.

\subsubsection{Herding over time}

The herding measure $R_{n, t}^{2}$ is relatively stable over time. Pension funds that are categorized as followers in one month are also categorized as followers in the subsequent months. To show this status, I sort pension funds into five quintiles based on their tendency to follow others. Within each quintile of $R_{n, t}^{2}$, I then sort pension funds into three terciles based on the number of months that each pension fund appears in the selected quintile. For example, within quintile 5 based on $R_{n, t}^{2}$ (the quintile of follower

\footnotetext{
${ }^{21}$ This analysis focuses on a few securities, specifically the first and fifth size quintile of securities in each pension fund's portfolio. Large return differentials in a few securities can lead to large standard errors in the t-tests on the average returns.
} 
pension funds), I sort pension funds into three terciles where tercile 3 is the tercile of pension funds that are more often followers. Similarly within quintile 1 of $R_{n, t}^{2}$, tercile 3 is the tercile of pension funds that are more often non-followers. This procedure generates 15 double-sorted portfolios of pension funds $(15 \times 3)$. There are seven pension funds that are often categorized as followers, and each of them is categorized as such in $53,55,50,47,53,34$, and 32 months out of the 119 in the sample period. The pension funds that are often categorized as non-followers are nine and each of them is categorized as such in 41, 52, 35, 33, 37, 34, 43, 58, and 36 months out of 119 . Figure 4-2 shows that there is no overlap between these two groups. Each number in the scatter plot refers to a unique pension fund. Followers and non-followers are two distinct groups of pension funds. The same pension fund does not appear as both a follower and non-follower over time. This uniqueness indicates that herding is a strategic decision, and it might be related to pension fund characteristics.

Next, I compute equally weighted returns of the double-sorted portfolio of pension funds. In Table 4.5 I compare the returns of pension funds in the double-sorted portfolio $5 / 3$ with the returns of pension funds in the double-sorted portfolio $1 / 3$. Namely, I compare the returns of pension funds that are more often categorized as followers with the results of pension funds that are more often categorized as nonfollowers. I also report the risk-adjusted returns of these portfolios as intercepts from the time-series regressions that use the capital asset pricing model (CAPM), the global three-factor model of Fama and French (2012) that is augmented with the global momentum factor, the North American market risk premium, size, and value factors. Pension funds that are more often categorized as followers underperform pension funds that are more often categorized as non-followers by $0.17 \%$ on a monthly basis and by $0.52 \%$ on a quarterly basis. This result is in line with the findings in Table 4.4 and indicates once again that herding negatively affects performance, as pension funds that herd more over time systematically perform worse than pension funds that herd less over time. The results are unchanged after controlling for different risk factors.

The negative effect on performance is likely due to the fact that by inferring in- 


\section{Figure 4-2. Followers and non-followers over time}

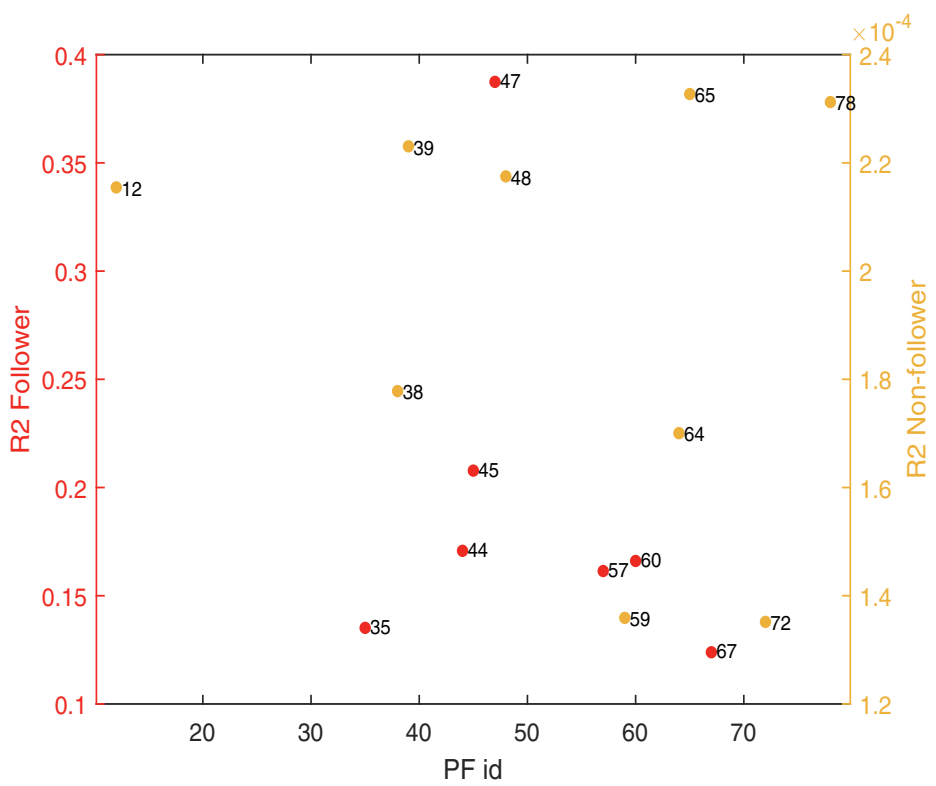

Notes: The figure shows the pension funds that are more often categorized as either followers (red dots) or nonfollowers (yellow dots). The pension funds are uniquely identified with numbers that are plotted on the X axis. At the end of each month, I sort pension funds into five quintiles based on the herding measure $R_{n, t}^{2}$. Within each quintile of $R_{n, t}^{2}$, I then sort pension funds into three terciles based on the number of months that each pension fund appears in the selected quintile of $R_{n, t}^{2}$. Pension funds that are more often categorized as followers are those in tercile 3 of frequency within quintile 5 of $R_{n, t}^{2}$. Similarly, Pension funds that are more often categorized as non-followers are those in tercile 3 of frequency within quintile 1 of $R_{n, t}^{2}$. The Y axis on the left shows the range of $R_{n, t}^{2}$ for followers. The $\mathrm{Y}$ axis on the right shows the range of $R_{n, t}^{2}$ for non-followers.

formation from others, pension funds might acquire non-timely information. Pension funds that do not herd appear to be the most skilled investors, which is in line with the evidence from mutual funds (Jiang and Verardo (2018)). Non-follower pension funds might be contrarian investors that consistently trade against the crowd, as described by Wei et al. (2015), or might trade a different set of securities from other pension funds. My findings are in line with the latter, as non-follower pension funds hold more different securities in their portfolios. The pension funds that are more often categorized as non-followers over time on average have more than 2,000 different securities in their portfolios, while the sample average has 1,464. This difference indicates that non-followers have a more diversified equity portfolio. In Figure 4-3 I show graphically that indeed there is a negative relation between the time-series average of the $R_{n, t}^{2}$ of a pension fund and the number of securities held. Pension 


\section{Table 4.5: Pension fund herding over time and portfolio performance}

\begin{tabular}{|c|c|c|c|}
\hline $\begin{array}{l}\text { Double sorting } \\
\text { Avg. } R_{n, t}^{2}\end{array}$ & $\begin{array}{c}(1 / 3) \\
0.0002\end{array}$ & $\begin{array}{c}(5 / 3) \\
0.1954 \\
\end{array}$ & $\begin{array}{c}(5 / 3)-(1 / 3) \\
0.1952 \\
\end{array}$ \\
\hline & \multicolumn{3}{|c|}{ Return month $t+1$ (\%) } \\
\hline Average & $\begin{array}{c}1.1651^{* * *} \\
(3.94)\end{array}$ & $\begin{array}{c}0.9933^{* * *} \\
\quad(3.23)\end{array}$ & $\begin{array}{c}-0.1719^{*} \\
(-1.88)\end{array}$ \\
\hline $\mathrm{CAPM} \alpha_{M S C I}$ & $\begin{array}{l}0.0911 \\
(1.37)\end{array}$ & $\begin{array}{c}-0.1160 \\
(-1.03)\end{array}$ & $\begin{array}{c}-0.2071^{* *} \\
(-2.18)\end{array}$ \\
\hline G4F $\alpha$ & $\begin{array}{l}0.1557 \\
(1.42)\end{array}$ & $\begin{array}{l}-0.0298 \\
(-0.19)\end{array}$ & $\begin{array}{c}-0.1855^{*} \\
(-1.86)\end{array}$ \\
\hline \multirow[t]{2}{*}{ NA3F $\alpha$} & $\begin{array}{l}-0.1035 \\
(-0.55) \\
\end{array}$ & $\begin{array}{l}-0.2830 \\
(-1.13) \\
\end{array}$ & $\begin{array}{c}-0.1795^{*} \\
(-1.76) \\
\end{array}$ \\
\hline & \multicolumn{3}{|c|}{ Return month $t+3(\%)$} \\
\hline Average & $\begin{array}{c}3.6403^{* * *} \\
(4.75)\end{array}$ & $\begin{array}{c}3.1165^{* * *} \\
(3.94)\end{array}$ & $\begin{array}{c}-0.5238^{* * *} \\
(-2.80)\end{array}$ \\
\hline $\mathrm{CAPM} \alpha_{M S C I}$ & $\begin{array}{c}0.4922^{* * * *} \\
\quad(2.66)\end{array}$ & $\begin{array}{l}-0.1295 \\
(-0.51)\end{array}$ & $\begin{array}{c}-0.6217^{* * *} \\
(-3.41)\end{array}$ \\
\hline G4F $\alpha$ & $\begin{array}{l}0.4056 \\
(1.52)\end{array}$ & $\begin{array}{l}-0.1512 \\
(-0.45)\end{array}$ & $\begin{array}{c}-0.5568^{* * *} \\
(-2.85)\end{array}$ \\
\hline NA3F $\alpha$ & $\begin{array}{l}-0.5227 \\
(-0.92)\end{array}$ & $\begin{array}{l}-1.0201 \\
(-1.50)\end{array}$ & $\begin{array}{c}-0.4974^{* *} \\
(-2.24)\end{array}$ \\
\hline
\end{tabular}

Notes: At the end of each month, I sort pension funds into five quintiles based on the herding measure $R_{n, t}^{2}$. Within each quintile of $R_{n, t}^{2}$, I then sort pension funds into three terciles based on the number of months that each pension fund appears in the selected quintile of $R_{n, t}^{2}$. Next, I compute equally-weighted returns of the double-sorted portfolio of pension funds. The double-sorted portfolios are formed at the end of each month from February 2009 to December 2018 and held for one or three months. I report equally weighted returns of the double-sorted pension fund portfolios over the next month and quarter (cumulative three-month returns). The table compares the returns of pension funds in the double-sorted portfolio $5 / 3$ ( $5^{\text {th }}$ quintile of $R_{n, t}^{2}$ and $3^{\text {rd }}$ frequency tercile) with the returns of pension funds in the double-sorted portfolio $1 / 3$ ( $1^{\text {st }}$ quintile of $R_{n, t}^{2}$ and $3^{\text {rd }}$ frequency tercile). Namely, in the table I compare the returns of pension funds that are more often categorized as follower pension funds over time with the results of pension funds that more often categorized as non-follower pension funds. The table also gives the risk-adjusted returns based on the CAPM and Fama and French (2012) global market size, value, and momentum factors (G4F) as well as North-American market, size and value factors (NA3F). The risk-adjusted returns are the intercept from a time-series regression of the double-sorted portfolios' excess returns over the US one-month T-bill rate on the risk factors. The CAPM market return is given by the monthly total return on the MSCI All Country World Index. For the time-series regression on North-American factors, the market risk premium is the return on the region's valueweighted market portfolio minus the US one-month T-bill rate. All factors are converted into euro returns. The t-statistics are in parentheses and are computed using Newey-West standard errors with three lags. The * indicates statistical significance at the $10 \%$ level, $* *$ at the $\% 5$ percent, and ${ }^{* * *}$ at the $1 \%$ level.

funds that herd more hold less securities than those that do not herd.

\subsubsection{Return prediction}

To further explore the relation between returns and herding, I estimate multivariate pooled OLSs for the performance of pension funds on herding and other pension fund characteristics. The measure of performance that I use is the monthly global fourfactor alpha estimated from the realized gross return of each pension fund in excess of the US one-month T-bill rate. The factor loadings are estimated with a rolling window time-series regression of the pension fund returns over the previous three 
Figure 4-3. Relation between herding and number of securities held over time

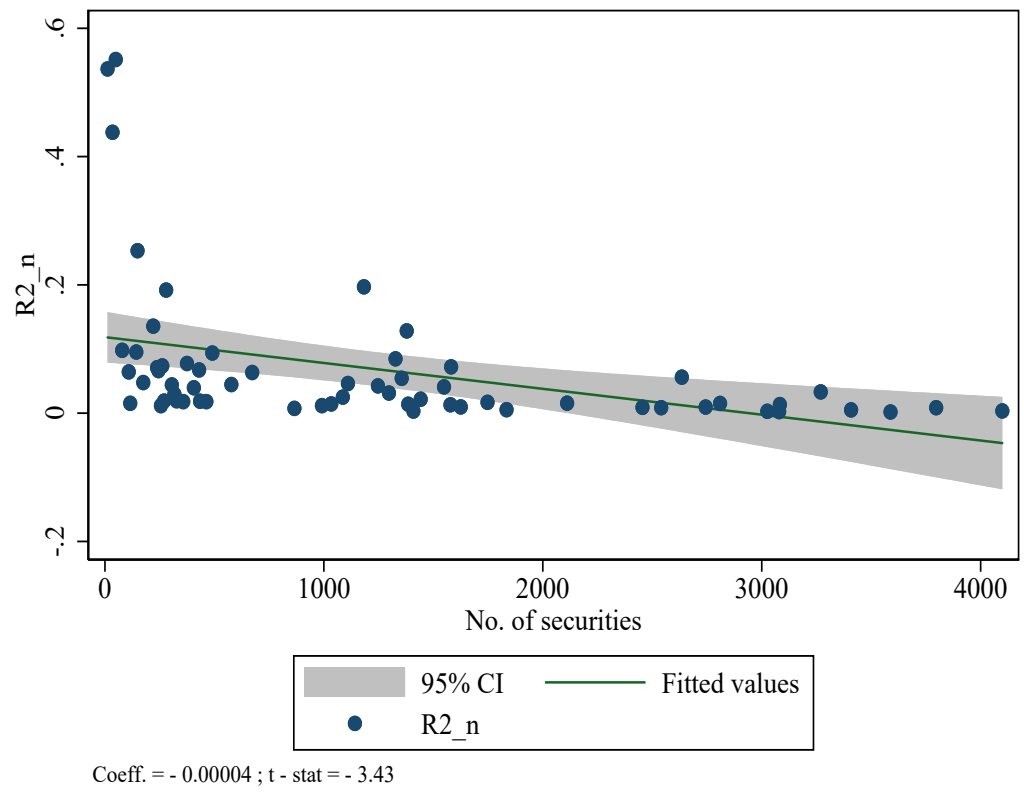

Notes: The figure shows the relation, together with the regression line, between the time-series average of the herding measure $R_{n, t}^{2}$ and the number of securities held by each pension fund $n$. The gray-shaded area represents the $95 \%$ confidence interval.

years.

Table 4.6 presents the predictive pooled OLS results. Columns (1) shows a univariate regression of the four-factor gross alphas on the lag measure of herding $\left(R_{n}^{2}\right)$. Herding negatively predicts future performance. The slope coefficient associated with the past level of $R_{n}^{2}$ is negative and significant at the $1 \%$ level. A $1 \%$ increase in the past level of $R_{n}^{2}$ is associated with a 0.0023 percentage points lower monthly alpha of a pension fund. After controlling for pension fund characteristics, in column (2), the relation between performance and herding remains significantly negative and almost unchanged in magnitude (coefficient $=-0.0020$ ). Hence, high herding predicts lower future risk-adjusted returns. Column (4) shows that after controlling for pension fund characteristics, follower pension funds are associated with a 0.05 percentage points lower next-month alpha. But column (6) indicates that non-followers are associated with a 0.02 percentage points higher next-month alpha. In line with the quintile- 
portfolio analysis, these results show that herding negatively affects performance.

\section{Table 4.6: Herding and pension fund future performance - Predictive re- gression}

\begin{tabular}{|c|c|c|c|c|c|c|}
\hline & $\begin{array}{c}(1) \\
\mathrm{G} 4 \mathrm{~F} \alpha_{t}\end{array}$ & $\begin{array}{c}(2) \\
\mathrm{G} 4 \mathrm{~F} \alpha_{t}\end{array}$ & $\begin{array}{c}(3) \\
\text { G4F } \alpha_{t}\end{array}$ & $\begin{array}{c}(4) \\
\text { G4F } \alpha_{t} \\
\end{array}$ & $\begin{array}{c}(5) \\
\mathrm{G} 4 \mathrm{~F} \alpha_{t}\end{array}$ & $\begin{array}{c}(6) \\
\text { G4F } \alpha_{t} \\
\end{array}$ \\
\hline$R_{n, t-1}^{2}$ & $\begin{array}{c}-0.0023^{* * *} \\
(-4.56)\end{array}$ & $\begin{array}{c}-0.0020^{* * *} \\
(-2.94)\end{array}$ & & & & \\
\hline Follower $_{t-1}$ & & & $\begin{array}{c}-0.0649^{* * *} \\
(-2.85)\end{array}$ & $\begin{array}{c}-0.0488^{* *} \\
(-2.30)\end{array}$ & & \\
\hline Non-Follower $_{t-1}$ & & & & & $\begin{array}{c}0.0295^{* *} \\
(2.38)\end{array}$ & $\begin{array}{c}0.0186^{*} \\
(1.83)\end{array}$ \\
\hline Corporate pension fund & & $\begin{array}{c}0.1090^{* *} \\
(2.10)\end{array}$ & & $\begin{array}{c}0.1087^{* *} \\
(2.11)\end{array}$ & & $\begin{array}{c}0.1076^{* *} \\
(2.04)\end{array}$ \\
\hline Industry-wide pension fund & & $\begin{array}{c}0.0809 \\
(1.42)\end{array}$ & & $\begin{array}{l}0.0809 \\
(1.43)\end{array}$ & & $\begin{array}{c}0.0802 \\
(1.40)\end{array}$ \\
\hline $\log \operatorname{size}_{t-1}$ & & $\begin{array}{c}0.0139 \\
(1.24)\end{array}$ & & $\begin{array}{c}0.0132 \\
(1.18)\end{array}$ & & $\begin{array}{l}0.0147 \\
(1.32)\end{array}$ \\
\hline Turnover $_{t-1}$ & & $\begin{array}{c}-0.0016^{* *} \\
(-2.13)\end{array}$ & & $\begin{array}{c}-0.0017^{* *} \\
(-2.30)\end{array}$ & & $\begin{array}{c}-0.0013^{*} \\
(-1.77)\end{array}$ \\
\hline Flow $_{t-1}$ & & $\begin{array}{c}-0.0014^{*} \\
(-1.86)\end{array}$ & & $\begin{array}{c}-0.0014^{*} \\
(-1.86)\end{array}$ & & $\begin{array}{c}-0.0013^{*} \\
(-1.71)\end{array}$ \\
\hline Constant & $\begin{array}{c}0.4337^{* * *} \\
(18.07) \\
\end{array}$ & $\begin{array}{l}0.1687 \\
(1.02) \\
\end{array}$ & $\begin{array}{c}0.4350^{* * *} \\
(18.25) \\
\end{array}$ & $\begin{array}{l}0.1804 \\
(1.09) \\
\end{array}$ & $\begin{array}{c}0.4173^{* * *} \\
(16.93) \\
\end{array}$ & $\begin{array}{l}0.1471 \\
(0.91) \\
\end{array}$ \\
\hline Observations & 3,368 & 3,265 & 3,368 & 3,265 & 3,368 & 3,265 \\
\hline$R^{2}$ & 0.189 & 0.257 & 0.190 & 0.259 & 0.178 & 0.252 \\
\hline
\end{tabular}

Notes: In column (1), the table presents the coefficients from predictive pooled OLSs that estimate the relation between future 4 -factor alpha (in \%) of pension funds and the herding measure $R_{n}^{2}$. In column (3), I include the dummy variable "Follower" that equals one if a pension fund $n$ falls within the $5^{t h}$ quintile of $R_{n}^{2}$. In column (5), I include the dummy variable "Non-Follower" that equals one if a pension fund $n$ falls within the $1^{\text {st }}$ quintile of $R_{n}^{2}$. In all specifications, the dependent variable is the monthly global four-factor alpha (in \%) that is estimated with rolling-window regressions over the previous three years of the excess return (over the US one-month T-bill rate) of each pension fund on the global market, size, value, and momentum factors from Fama and French (2012). Columns $(2),(4)$, and (6), include control variables for the type of pension fund, prior-month pension fund size, prior-month turnover, and prior-month flow. The types of pension funds are the industry-wide pension fund and corporate pension fund, and the omitted category is pension asset management firms. All models are estimated with month fixed effects and standard errors clustered at the pension fund level. The t-statistics are in parenthesis. The * indicates statistical significance at the $10 \%$ level, ${ }^{* *}$ at the $5 \%$ level, and ${ }^{* * *}$ at the $1 \%$ level.

Table 4.6 also indicates that corporate pension funds show greater performance than pension asset management firms and that low portfolio turnover positively predicts future alpha, which is in line with the results from mutual funds (Carhart (1997)). Moreover, size does not predict better future performance in public equity. However, size is not unrelated to investment skills. In Table 4.13 of section 4.A.2 in the appendix, I show that size positively predicts the next-month alpha if correlated variables such as the type of pension fund and herding are dropped. 


\subsection{Determinants of herding}

The results from the previous subsections lead to a natural question: if herding does not lead to greater performance, why do pension funds herd? In this subsection, I investigate the relation between the herding measure and several pension fund characteristics to understand which ones drive pension funds to herd.

To address this question, I begin by estimating pooled OLSs of $R_{n, t}^{2}$ on a number of pension fund characteristics such as the type of institution which is a categorical variable to identify either industry-wide pension funds, corporate pension funds, or pension asset management firms ${ }^{22}$ Other characteristics are size (measured as the natural logarithm of the total equity portfolio), turnover, flow, and past returns. Given that pension funds herd more in some equity markets than others, I investigate the relation between $R_{n}^{2}$ and pension fund characteristics in developed and emerging markets separately as well as in large and small capitalization securities separately. Columns (1), (3), (5), and (7) in Table 4.7 present the results for each subset of securities. As a robustness test, I also estimate logit regressions in which the dependent variable is binary and equals one if a pension fund is classified as a follower; that is, it belongs to the $5^{\text {th }}$ quintile of the $R_{n}^{2}$ distribution in a given month. The logit regressions are presented in columns (2), (4), (6), and (8).

In all equity markets, small pension funds display a higher $R_{n, t}^{2}$ and are more likely to be followers $\left.{ }^{23}\right|^{4}$ Moreover, pension funds with a lower turnover ratio are also associated with a higher $R_{n, t}^{2}$ and therefore are more likely to be followers. Thus, the pension funds that herd more are generally small and trade less frequently. These results indicate that herding is related to skills and that small pension funds might

\footnotetext{
${ }^{22}$ Pension asset management firms are asset management firms that report the holdings of pension funds that are not required to directly report. Therefore, these firms typically manage the assets of small pension funds.

${ }^{23}$ Table 4.14 in section 4. A.3 of the appendix shows that the results are really similar, if I also include the number of securities as additional explanatory variables. The number of securities is dropped from the main analysis because it correlates with portfolio size.

${ }^{24}$ The Dutch occupational pension sector is characterized by a few very large pension funds. Thus, outliers might drive the relation between herding and size. In section 4.A.4. I study the relation between herding and size by using piecewise-linear segments of size as independent variables replacing log size. In Table 4.15. I show that within groups of pension funds of similar size, smaller pension funds still herd more.
} 
Table 4.7: Determinants of herding

\begin{tabular}{lcccccccc}
\hline \hline & \multicolumn{2}{c}{ Developed markets } & \multicolumn{2}{c}{ Emerging } & markets & \multicolumn{2}{c}{ Large cap } & \multicolumn{2}{c}{ Small cap } \\
\cline { 2 - 8 } & $(1)$ & $(2)$ & $(3)$ & $(4)$ & $(5)$ & $(6)$ & $(7)$ & $(8)$ \\
& $R_{n, t}^{2}$ & Follower & $R_{n, t}^{2}$ & Follower & $R_{n, t}^{2}$ & Follower & $R_{n, t}^{2}$ & Follower \\
\hline Corporate Pf. & -0.000 & 0.082 & 0.069 & $0.616^{*}$ & $0.052^{* *}$ & 0.530 & -0.049 & -0.289 \\
& $(-0.01)$ & $(0.22)$ & $(1.42)$ & $(1.75)$ & $(2.24)$ & $(1.49)$ & $(-1.00)$ & $(-0.78)$ \\
Industry Pf. & 0.006 & 0.190 & 0.015 & 0.041 & 0.025 & 0.333 & -0.006 & -0.048 \\
& $(0.27)$ & $(0.48)$ & $(0.33)$ & $(0.09)$ & $(1.13)$ & $(0.89)$ & $(-0.12)$ & $(-0.13)$ \\
Log size & $-0.014^{* * *}$ & $-0.422^{* * *}$ & $-0.085^{* * *}$ & $-0.902^{* * *}$ & $-0.028^{* * *}$ & $-0.485^{* * *}$ & $-0.067^{* * *}$ & $-0.581^{* * *}$ \\
& $(-3.86)$ & $(-4.26)$ & $(-5.14)$ & $(-7.67)$ & $(-3.72)$ & $(-4.72)$ & $(-4.74)$ & $(-3.92)$ \\
Turnover & $-0.153^{* * *}$ & $-18.370^{* * *}$ & $-0.318^{*}$ & $-3.836^{*}$ & $-0.251^{* * *}$ & $-16.032^{* * *}$ & $-0.253^{* * *}$ & $-2.575^{*}$ \\
& $(-4.74)$ & $(-4.75)$ & $(-1.72)$ & $(-1.70)$ & $(-4.43)$ & $(-4.87)$ & $(-2.92)$ & $(-1.80)$ \\
Flow & 0.027 & -0.693 & 0.008 & -0.024 & 0.045 & -2.452 & 0.039 & 0.952 \\
& $(1.53)$ & $(-0.28)$ & $(0.09)$ & $(-0.03)$ & $(1.49)$ & $(-1.15)$ & $(0.92)$ & $(1.57)$ \\
Return & 0.304 & 1.149 & -0.461 & 0.486 & -0.137 & -2.641 & -0.207 & 0.039 \\
& $(1.19)$ & $(0.34)$ & $(-0.77)$ & $(0.09)$ & $(-0.28)$ & $(-0.63)$ & $(-0.35)$ & $(0.01)$ \\
Constant & $0.231^{* * *}$ & $4.190^{* * *}$ & $1.445^{* * *}$ & $10.031^{* * *}$ & $0.432^{* * *}$ & $5.045^{* * *}$ & $1.091^{* * *}$ & $6.397^{* * * *}$ \\
& $(4.95)$ & $(3.38)$ & $(6.72)$ & $(6.82)$ & $(4.25)$ & $(4.00)$ & $(6.01)$ & $(3.40)$ \\
\hline Observations & 5,273 & 5,273 & 4,500 & 4,418 & 5,244 & 5,244 & 4,732 & 4,732 \\
$R^{2}$ & 0.053 & & 0.182 & & 0.104 & & 0.132 & 0.097 \\
Pseudo $R^{2}$ & & 0.073 & & 0.166 & & 0.092 & & \\
\hline \hline
\end{tabular}

Notes: This table presents columns (1), (3), (5), and (7) the estimated coefficients from pooled OLSs of $R_{n}^{2}$, the follower measure, on pension fund characteristics. Also, the table presents in columns (2), (4), (6), and (8) the estimate coefficients from logit regressions of "Follower" that is a binary variable that equals one if pension fund $n$ falls within the $5^{\text {th }}$ quintile of $R_{n}^{2}$ on pension fund characteristics. The types of pension funds are the industry-wide pension fund and the corporate pension fund, the omitted category is pension asset management firms. Log size is the natural logarithm of the total equity portfolio of the pension fund. Turnover is the turnover ratio. Flow is the pension fund flow in the previous month. Return $t_{-1}$ is the previous month gross return of the pension fund. All models are estimated with month fixed effects and standard errors clustered at the pension fund level. The t-statistics are in parentheses, The ${ }^{*}$ indicates statistical significance at the $10 \%$ level, ${ }^{* *}$ at the $\% 5$ level, and ${ }^{* * *}$ at the $1 \%$ level.

not be able to select the more skilled asset managers and in turn decide to herd. On the one hand, this relation can be interpreted as small pension funds trying to learn from other, possibly more skilled, pension funds. On the other hand, the earlier finding of persistent herding over time indicates that it is a strategic decision that might arise from the fear of underperforming peers. Hence, small pension funds might herd on the trades of large and more media-covered pension funds Goyal and Wahal (2008) ) because of reputational concerns. In fact, large pension funds are less likely to herd.Information about large (and generally more media covered) pension funds' investment strategies may also be more easily observable by others. For example, these pension funds may employ several brokers who can spread their order flows across their other clients (Barbon et al. (2019)). Furthermore, small pension funds have generally less in-house expertise and therefore tend to delegate more decisions to their asset managers. Asset management firms have the incentive to retain their clients. Therefore, herding can be a strategy to reduce their responsibility in the 
event of poor performance.

Herding is not affected by passive investing. I hand collected data on the type of equity mandates from the annual reports of the pension funds in the sample. In each annual report, I searched whether a pension would declare that part or the entirety of their equity portfolio was actively or passively managed. On average $60 \%$ of the pension funds declare that they mainly rely on active management in their public equity portfolio. However, the number of pension funds in the sample that rely on active management has decreased significantly over time: from 29 in 2009 to 14 in 2018, see Figure 4-4.

\section{Figure 4-4. Number of pension funds relying on active management}

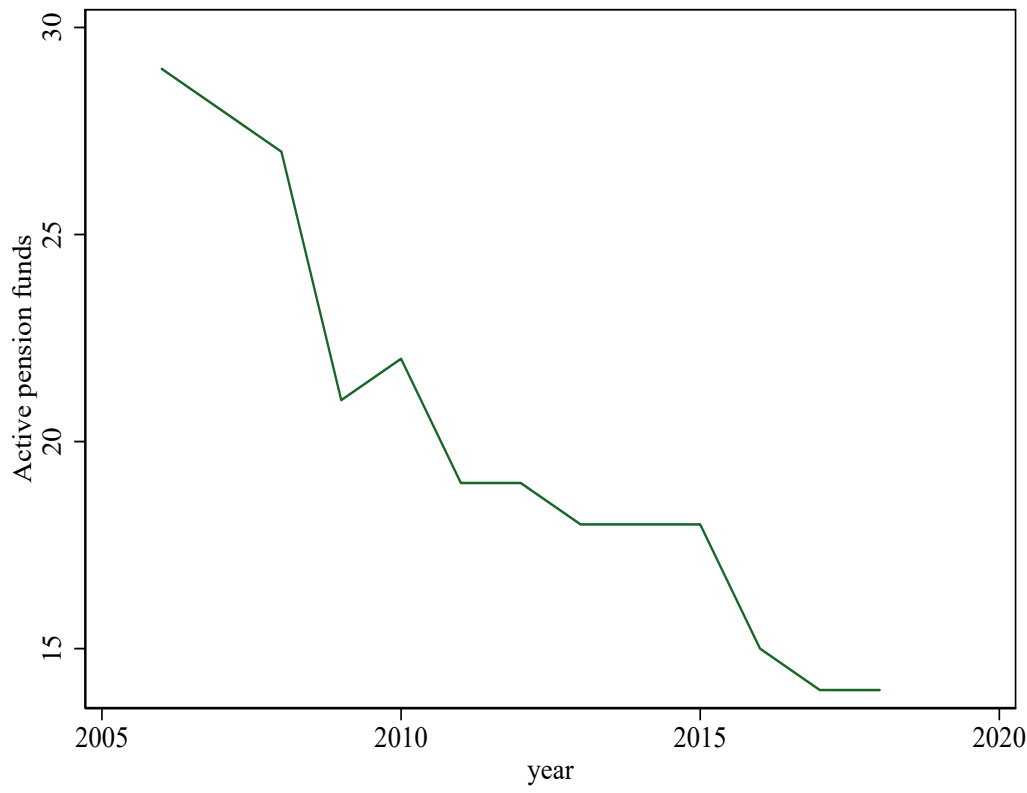

Notes: The figure shows the number of pension funds that report in their annual report that part or the entirety of their public equity portfolio is actively managed.

In Table 4.8 I reestimate the relation between herding and pension fund characteristics after adding a dummy variable that equals one if a pension fund relies on active management in a given month and zero if it relies on passive management. ${ }^{25}$ Herding

\footnotetext{
${ }^{25}$ This information is only available on a yearly basis. Therefore, the variable is kept constant for each month in a given year. Changes always occur in January.
} 
is not affected by the decision of pension funds to rely on active or passive management. Moreover, the coefficients for the other variables are basically unchanged compared to those in Table 4.7

Table 4.8: Determinants of herding - the effect of active/passive management

\begin{tabular}{lcccccccc}
\hline \hline & \multicolumn{2}{c}{ Developed markets } & \multicolumn{2}{c}{ Emerging } & \multirow{2}{*}{ markets } & \multicolumn{2}{c}{ Large cap } & \multicolumn{2}{c}{ Small cap } \\
\cline { 2 - 9 } & $(1)$ & $(2)$ & $(3)$ & $(4)$ & $(5)$ & $(6)$ & $(7)$ & $(8)$ \\
& $R_{n, t}^{2}$ & Follower & $R_{n, t}^{2}$ & Follower & $R_{n, t}^{2}$ & Follower & $R_{n, t}^{2}$ & Follower \\
\hline Active & -0.007 & -0.258 & 0.017 & 0.351 & -0.040 & -0.317 & -0.014 & -0.049 \\
& $(-0.65)$ & $(-0.68)$ & $(0.36)$ & $(0.95)$ & $(-1.21)$ & $(-0.72)$ & $(-0.31)$ & $(-0.11)$ \\
Corporate Pf. & -0.007 & 0.081 & 0.077 & 0.647 & 0.015 & 0.295 & -0.014 & 0.020 \\
& $(-0.56)$ & $(0.22)$ & $(1.34)$ & $(1.36)$ & $(0.42)$ & $(0.69)$ & $(-0.26)$ & $(0.04)$ \\
Log size & $-0.014^{* * *}$ & $-0.430^{* * *}$ & $-0.059^{* * *}$ & $-0.694^{* * *}$ & $-0.032^{* *}$ & $-0.488^{* * *}$ & $-0.048^{* * *}$ & $-0.413^{* *}$ \\
& $(-3.29)$ & $(-3.31)$ & $(-3.69)$ & $(-4.73)$ & $(-2.67)$ & $(-3.52)$ & $(-3.06)$ & $(-2.57)$ \\
Turnover & $-0.175^{* * *}$ & $-29.642^{* * *}$ & $-0.691^{* * *}$ & $-8.049^{* *}$ & $-0.347^{* * *}$ & $-14.783^{* * *}$ & $-0.320^{* *}$ & $-4.588^{*}$ \\
& $(-3.43)$ & $(-4.52)$ & $(-2.82)$ & $(-2.52)$ & $(-3.37)$ & $(-3.25)$ & $(-2.68)$ & $(-1.94)$ \\
Flow & $0.062^{* * *}$ & 2.655 & 0.030 & -1.251 & $0.169^{* * *}$ & -1.275 & 0.124 & -0.012 \\
& $(2.82)$ & $(0.70)$ & $(0.20)$ & $(-0.51)$ & $(3.45)$ & $(-0.36)$ & $(1.33)$ & $(-0.01)$ \\
Return & 0.072 & -4.998 & -1.565 & -6.438 & -0.620 & -3.081 & 0.322 & 3.255 \\
& $(0.21)$ & $(-1.14)$ & $(-1.70)$ & $(-0.62)$ & $(-0.69)$ & $(-0.47)$ & $(0.39)$ & $(0.48)$ \\
Constant & $0.294^{* * *}$ & $5.608^{* * *}$ & $1.277^{* * *}$ & $8.271^{* * *}$ & $0.577^{* * *}$ & $5.465^{* * *}$ & $0.804^{* * *}$ & 3.322 \\
& $(3.88)$ & $(2.99)$ & $(4.84)$ & $(3.93)$ & $(3.27)$ & $(2.65)$ & $(3.62)$ & $(1.48)$ \\
\hline Observations & 2,948 & 2,948 & 2,399 & 2,357 & 2,904 & 2,904 & 2,708 & 2,690 \\
$R^{2}$ & 0.084 & & 0.168 & & 0.142 & & 0.109 & 0.086 \\
Pseudo $R^{2}$ & & 0.116 & & 0.154 & & 0.131 & & 0.086 \\
\hline \hline
\end{tabular}

Notes: This table presents in columns (1), (3), (5), and (7) the estimated coefficients from pooled OLSs of $R_{n}^{2}$, the follower measure, on pension fund characteristics. Also, the table presents in columns (2), (4), (6), and (8) the estimate coefficients from logit regressions of "Follower" that is a binary variable that equals one if pension fund $n$ falls within the $5^{\text {th }}$ quintile of $R_{n}^{2}$ on pension fund characteristics. Active is a dummy variable that equals one if a pension fund declares in its annual report that it relies on active management and zero if it relies on passive management. The types of pension funds are the corporate pension fund and the industry-wide pension fund (omitted category). The type "Pension asset management firm" is not included in the regression because these are all active investors. $\log$ size is the natural logarithm of the total equity portfolio of the pension fund. Turnover is the turnover ratio. Flow is the pension fund flow in the previous month. Return $t-1$ is the previous month's gross return of the pension fund. All models are estimated with month fixed effects and standard errors clustered at the pension fund level. The t-statistics are in parentheses, The * indicates statistical significance at the $10 \%$ level, ${ }^{* *}$ at the $\% 5$ level, and ${ }^{* * *}$ at the $1 \%$ level.

\subsection{Alternative explanations for herding}

The correlation between the fraction of pension funds that buy or sell the same securities this month and the fraction of pension funds that buy or sell the same securities last month might arise mechanically for reasons other than pension funds following themselves or each other into and out of the same securities over subsequent months. For example, pension funds might display correlated trades because they hold similar portfolios and have correlated net flows, or because of style investing 
(Barberis and Shleifer (2003)).

\subsubsection{Habit investing}

Pension funds might display correlated trades because they hold similar portfolios. In this case, the cross-sectional and time-series correlations in their net flows could result in correlated trades. This type of herding is defined as "habit investing" ${ }^{26}$ Habit investing may arise because of three mechanical reasons. First, if pension funds have similar portfolios because they hold the same securities; second, if pension funds' cash inflows are positively correlated, that is, contributions are paid in the same period or are exposed to common shocks; third, if pension funds invest their incoming contributions proportionally in existing portfolios, then pension funds will mechanically follow each other into the same securities over subsequent periods.

To investigate if habit investing drives herding, I examine the correlation between the fraction of pension funds that increase the return-adjusted portfolio weights over subsequent months, which is in line with Sias (2004). If a pension fund's objective is to maintain a similar portfolio over time when new contributions are flowing in, it would buy securities in proportion to its current holdings. Therefore, portfolio weights would not change and consequently the portfolio weights of different pension funds would be independent over subsequent periods. Alternatively, if pension funds follow themselves and each other into the same security for reasons other than maintaining constant portfolio weights and correlated net-flows, then the fraction of pension funds that increase their portfolio weights would be positively correlated over subsequent months.

To test this hypothesis, I begin by defining the return-adjusted portfolio weight in each security as the month-end portfolio weight if no trades were made during the month. For each security and month between January 2009 and December 2018, I

\footnotetext{
${ }^{26} \mathrm{Habit}$ investing also occurs if pension funds follow passive strategies that track the same index. In this case, contributions are reinvested proportionally in all securities to mimic the weights of each security in the index. However, even if pension funds passively track the same index, herding might still be costly for late followers. In fact, pension funds that are the last ones to rebalance their portfolio in line with the underlying index may face negative price effects as earlier trades have influenced the current prices
} 
define $V_{n, j, t}$ as the value of pension fund $n$ 's position in security $j$ at the end of month $t$; that is, the price at the end of month $t$ times the number of securities held. Pension fund $n$ is defined as increasing its return-adjusted portfolio weight if its month-end portfolio weight $\left(w_{n, j, t}^{a d j}\right)$ is greater than its return-adjusted portfolio weight at the beginning of the month $\left(w_{n, j, t-1}^{a d j}\right)$. Hence, a pension fund is a buyer if:

$$
w_{n, j, t}^{a d j}>w_{n, j, t-1}^{a d j} \equiv \frac{V_{n, j, t}}{\sum_{j=1}^{J} V_{n, j, t}}>\frac{V_{n, j, t-1}\left(1+r_{j, t}\right)}{\sum_{j=1}^{J} V_{n, j, t-1}\left(1+r_{j, t}\right)}
$$

where $r_{j, t}$ is the return of security $j$ in month $t{ }^{27}$ Pension fund $n$ is defined as decreasing its return-adjusted portfolio weight (seller) if its month-end portfolio weight $\left(w_{n, j, t}^{a d j}\right)$ is smaller than its return-adjusted portfolio weight at the beginning of month $\left(w_{n, j, t-1}^{a d j}\right)$. If $w_{n, j, t}^{a d j}$ equals $w_{n, j, t-1}^{a d j}$, then pension fund $n$ is classified as neither a buyer nor a seller.

Next, for each security and month between January 2009 and December 2018, I compute the raw fraction of pension funds that increase their return-adjusted portfolio weights for the security:

$$
\operatorname{Raw} \Delta_{j, t}^{w}=\frac{\text { No. of Pfs. increasing } w_{n, j, t}^{a d j}}{\text { No. of Pfs. increasing } w_{n, j, t}^{a d j}+\text { No. of Pfs. decreasing } w_{n, j, t}^{a d j}}
$$

Each month, I standardize $\operatorname{Raw} \Delta_{j, t}^{w}$ to have a mean equal to zero and a variance equal to one, as in Equation 4.3. Then, I estimate a cross-sectional regression (across $J$ securities) of the standardized fraction of pension funds that increase their return-adjusted portfolio weight on the standardized lag fraction of pension funds that increase their return-adjusted portfolio weights for each month, as in Equation 4.4. Next, I decompose the regression coefficient into the portion of correlations due to pension funds following themselves and each other into and out of the same securities, as in Equation (4.5).

Table 4.9 presents the time-series average of the 119 correlation coefficients and

\footnotetext{
${ }^{27}$ Since pension funds invest in international securities, $r_{j, t}$ is not only the total security return, but it also includes appreciation and depreciation due to exchange rate fluctuations.
} 
Table 4.9: Aggregate herding - buyer if increased return-adjusted portfolio weight

\begin{tabular}{|c|c|c|c|c|}
\hline & $\begin{array}{l}\text { Time-series } \\
\text { avg. } \beta \text { coeff. }\end{array}$ & $\begin{array}{l}\text { Pf. following } \\
\text { their own weights }\end{array}$ & $\begin{array}{l}\text { Pf. following } \\
\text { others' weights }\end{array}$ & Avg. $R^{2}$ \\
\hline Panel A: Securities with $\geq 3$ traders & $\begin{array}{c}0.1406^{* * *} \\
(8.68)\end{array}$ & $\begin{array}{c}0.0911^{* * *} \\
(4.91)\end{array}$ & $\begin{array}{c}0.0495^{* * *} \\
(3.17)\end{array}$ & $\begin{array}{c}0.0508^{* * *} \\
(9.84)\end{array}$ \\
\hline Panel B: Securities with $\geq 5$ traders & $\begin{array}{c}0.1551^{* * *} \\
(12.80)\end{array}$ & $\begin{array}{c}0.0953^{* * *} \\
(5.57)\end{array}$ & $\begin{array}{l}0.0599^{* * *} \\
\quad(3.72)\end{array}$ & $\begin{array}{l}0.0414^{* * *} \\
\quad(9.91)\end{array}$ \\
\hline Panel C: Securities with $\geq 10$ traders & $\begin{array}{c}0.1884^{* * *} \\
(21.06)\end{array}$ & $\begin{array}{c}0.0983^{* * *} \\
(10.16)\end{array}$ & $\begin{array}{c}0.0901^{* * *} \\
(9.05)\end{array}$ & $\begin{array}{c}0.0449^{* * *} \\
(14.01)\end{array}$ \\
\hline
\end{tabular}

Notes: For each security and month between January 2009 and December 2018, I compute the fraction of pension funds (Pf) that increase their return-adjusted portfolio weight of the security. A pension fund is defined as increasing this weight (buyer) if it is greater than their return-adjusted beginning-of-month portfolio weight, as described in Equation 4.8. Each month, I standardize both the fraction of pension funds that increase their return-adjusted portfolio weight and the lag fraction of pension funds that increase it to a zero mean and a unit variance. Then, I estimate a cross-sectional regression (across $J$ securities) of the standardized fraction of pension funds that increase their return-adjusted portfolio weight on the lag standardized fraction of pension funds increase it for each month: Equation 4.4. Next, I decompose the regression coefficient into the portion of correlations that arises from pension funds following themselves and following each other i.e., Equation 4.5. The first column presents the time-series average of 119 correlation coefficients. The second and third columns give the time-series average of the portion of correlations that arises from pension funds following themselves and each other's changes in the return-adjusted portfolio weights. The fourth column presents the time-series average of the $R^{2}$ of the 119 cross-sectional regressions. The associated t-statistics are reported in parentheses. The * indicates statistical significance at the $10 \%$ level, $* *$ at the $\% 5$ level, and $* * *$ at the $1 \%$ level. Panels $\mathrm{A}, \mathrm{B}$, and $\mathrm{C}$ give the results when limiting the sample to securities with at least 3,5 , or 10 trading funds.

the time-series average of the two components of the correlation. The results show that the faction of pension funds that increase their return-adjusted portfolio weights is correlated with the lag fraction of pension funds that increase their return-adjusted portfolio weights. Both the portion of correlations that arise from pension funds following their own return-adjusted portfolio weight changes and each other's returnadjusted portfolio weight changes are statistically and significantly different from zero, and with similar magnitude to the coefficients in Table 4.3 . Herding is slightly lower that indicates a small portion of it is driven by pension funds mechanically reinvesting their net flows in the same portion as the existing holdings, that is, habit investing. However, the portion of correlation that arises from pension funds that follow each other's return-adjusted portfolio weights is strong in all groups of securities, and this strength confirms the existence of herding.

\subsubsection{Herding and style investing}

Pension funds might herd because of common investment styles. If pension funds pursue style investing, they will invest in securities with particular characteristics 
like large capitalization, high book-to-market ratios, or momentum. For example, pension funds might herd because their demand is positively correlated with the prior month's security returns, if pension funds are momentum traders ${ }^{28}$ To test this conjecture, I add the lag standardized return of the security in Equation $4.4{ }^{29}$ Specifically, for each month I regress the standardized fraction of pension funds that buy security $j$ on the lag standardized fraction of pension funds that buy security $j$ and the standardized lag return of $j$ :

$$
\Delta_{j, t}=\beta_{1, t} \Delta_{j, t-1}+\beta_{2, t} r_{j, t-1}+\epsilon_{j, t}
$$

All the variables are standardized in such a way as to have a mean equal to zero and a variance equal to one each month. To account for other styles, I also estimate Equation 4.10 by replacing the lag standardized return with the lag standardized market capitalization and the lag standardized book-to-market ratio. Moreover, I estimate Equation 4.10 by adding all three security characteristics. Table 4.10 presents the time-series average of the regression coefficients for the samples that include all securities with at least 3, 5, or 10 traders.

The results show that adding the lag standardized return, or other lag standardized security characteristics, to the regression has little effect on herding. In all samples, the average coefficients associated with the lag standardized fraction of pension funds that buy are comparable in magnitude to the average coefficients in Table 4.3 The average coefficient associated with the lag standardized return, or other security characteristics, is small compared to the average coefficients associated with the lag standardized fraction of pension funds that buy. Furthermore, the average $R^{2}$ in all panels of Table 4.10 are similar to the average $R^{2}$ in Table 4.3 . Therefore, adding lag returns, or other security characteristics, does not significantly improve the model.

The average coefficient associated with the lag standardized return is not statis-

\footnotetext{
${ }^{28}$ Momentum trading is a form of characteristics herding, that is, pension funds might follow each other because they are attracted by securities with high lag returns. Several studies have shown that institutional investors are momentum traders (see, e.g., Grinblatt et al. (1995), Nofsinger and Sias (1999), Wermers (1999), Sias (2004), Sias et al. (2006), Sias et al. (2015)).

${ }^{29} \mathrm{As}$ described in Section 4.2 , the standardization of the independent variables allows to aggregate coefficients over time and to easily compare them.
} 
Table 4.10: Aggregate herding and style investing

\begin{tabular}{|c|c|c|c|c|}
\hline & $\begin{array}{c}\text { Time-series avg. } \\
\beta \text { coeff. }\end{array}$ & $\begin{array}{c}\text { Time-series avg. } \\
\text { lag return }\end{array}$ & $\begin{array}{l}\text { Time-series avg. } \\
\text { lag mkt. cap. }\end{array}$ & $\begin{array}{l}\text { Time-series avg. } \\
\text { lag book-to-mkt }\end{array}$ \\
\hline \multirow[t]{4}{*}{ Panel A: Securities $\geq 3$ trader } & $\begin{array}{c}0.1970^{* * *} \\
(33.63)\end{array}$ & $\begin{array}{l}-0.0063 \\
(-1.39)\end{array}$ & & \\
\hline & $\begin{array}{c}0.1971^{* * *} \\
(33.97)\end{array}$ & & $\begin{array}{l}0.0045 \\
(0.84)\end{array}$ & \\
\hline & $\begin{array}{c}0.1969^{* * *} \\
(33.38)\end{array}$ & & & $\begin{array}{c}0.0053 \\
(1.07)\end{array}$ \\
\hline & $\begin{array}{c}0.1965^{* * *} \\
(34.11) \\
\end{array}$ & $\begin{array}{r}-0.0066 \\
(-1.53) \\
\end{array}$ & $\begin{array}{l}0.0054 \\
(1.03) \\
\end{array}$ & $\begin{array}{l}0.0054 \\
(1.15)\end{array}$ \\
\hline \multirow[t]{4}{*}{ Panel B: Securities $\geq 5$ trader } & $\begin{array}{c}0.1943^{* * *} \\
(29.62)\end{array}$ & $\begin{array}{c}-0.0164^{* * *} \\
(-3.08)\end{array}$ & & \\
\hline & $\begin{array}{c}0.1951^{* * *} \\
(29.98)\end{array}$ & & $\begin{array}{c}-0.0024 \\
(-0.39)\end{array}$ & \\
\hline & $\begin{array}{c}0.1945^{* * * *} \\
(29.13)\end{array}$ & & & $\begin{array}{c}0.0205^{* * *} \\
(3.51)\end{array}$ \\
\hline & $\begin{array}{c}0.1945^{* * *} \\
(29.91) \\
\end{array}$ & $\begin{array}{c}-0.0167^{* * *} \\
(-3.35) \\
\end{array}$ & $\begin{array}{c}-0.0001 \\
(-0.02) \\
\end{array}$ & $\begin{array}{c}0.0190^{* * *} \\
(3.44) \\
\end{array}$ \\
\hline \multirow[t]{4}{*}{ Panel C: Securities $\geq 10$ trader } & $\begin{array}{c}0.1979^{* * *} \\
(21.65)\end{array}$ & $\begin{array}{c}-0.0415^{* * *} \\
(-4.99)\end{array}$ & & \\
\hline & $\begin{array}{c}0.1992^{* * *} \\
(21.72)\end{array}$ & & $\begin{array}{c}-0.0453^{* * *} \\
(-5.46)\end{array}$ & \\
\hline & $\begin{array}{c}0.1957^{* * *} \\
(21.32)\end{array}$ & & & $\begin{array}{c}0.0622^{* * *} \\
(8.57)\end{array}$ \\
\hline & $\begin{array}{c}0.1950^{* * *} \\
(21.59) \\
\end{array}$ & $\begin{array}{c}-0.0379^{* * *} \\
(-4.72) \\
\end{array}$ & $\begin{array}{c}-0.0395^{* * *} \\
(-4.91) \\
\end{array}$ & $\begin{array}{c}0.0522^{* * *} \\
(7.57) \\
\end{array}$ \\
\hline
\end{tabular}

Notes: For each security and month between January 2009 and December 2018, I compute the fraction of pension funds (Pf) that increase their position in the security, as in Equation 4.2 . Pension funds are defined as increasing their position (buyers) if they hold a greater number of split-adjusted securities at the end of the month than they held at the beginning. Each month I regress the standardized fraction of pension funds that buy security $j$ on the standardized lag fraction of pension funds that buy security $j$ and the standardized lag return of $j$, or the standardized lag market capitalization or the standardized lag book-to-market ratio: Equation 4.10. Adding these security-level variables allows me to correct for style investing such as: momentum and large or value securities. Standardization (i.e., each month all variables are scaled to have a zero mean and a unit variance) allows me to directly compare the coefficients that are associated with the independent variables over different months. Panel A presents the time-series average of the 119 monthly cross-sectional regression coefficients, when limiting the sample to securities in at least three traders. The associated t-statistics are in parentheses. Panel B limits the sample to securities with at least five trading funds, and Panel $\mathrm{C}$ limits the sample to securities in at least 10 trading funds. The * indicates statistical significance at the $10 \%$ level, ${ }^{* *}$ at the $\% 5$ level, and ${ }^{* * *}$ at the $1 \%$ level.

tically different from zero when limiting the sample to securities with at least three traders. In the sample of securities with at least 5 or 10 traders the average coefficient associated with the lag standardized return is negative that means the pension funds are countercyclical traders rather than momentum traders. To conclude, the herding of pension funds is not driven by past returns, security size, or book-to-market ratio. Even if all three styles are added together in the regression, the results remain unchanged. 


\subsection{Conclusion}

In this paper, I study herding in the equity investments of Dutch occupational pension funds, and I investigate whether that herding influences their performance. I begin my analysis by measuring herding across all pension funds as in Sias (2004); that is, the correlation among the demand of all pension funds for the same securities over time. Then, I introduce a pension fund-level measure of herding that identifies the extent to which a pension fund follows other pension funds. A follower is a pension fund whose future trades are largely explained by the trades of all other pension funds.

I find significant herding among all pension funds. However, pension funds that herd more underperform those that do not herd by $1.32 \%$ on an annual basis. This underperformance persists after controlling for different risk-exposure and pensionfund characteristics. Herding is related to scale, as small pension funds are more likely to herd. These pension funds may not be able to select skilled asset managers and in turn decide to herd. In addition, pension funds that trade less frequently also herd more. This herding indicates that pension funds that cannot afford trading strategies involving a lot of trades may decide to herd as well.

Herding is stronger in markets with high information asymmetries like small capitalization and emerging markets. Therefore, small pension funds that generally have less resources to use for research might herd to learn from other pension funds. In fact, the information inferred is not timely, as pension funds that herd underperform pension funds that do not herd by $2.76 \%$ on an annual basis in emerging markets. The fact that pension funds herd regardless of whether it leads to better performance indicates that they might do so out of reputational concerns. The fear of underperforming their peers can push pension funds to follow each other. Indeed, herding is a strategic decision because pension funds herd consistently over time. 


\section{A Appendix}

\section{A.1 Returns of followers in different markets}

In this subsection, I examine the difference in performances between follower and nonfollower pension funds by only focusing on small capitalization and large capitalization securities. To perform this analysis, I sort all the securities traded by at least three pension funds in each month into five quintiles based on their beginning-of-month market capitalization. I then estimate Equation 4.6 for the bottom and top quintile of securities separately. Next, I compute $R_{n}^{2}$ for both the bottom and top quintiles of market capitalization. Hence, I identify follower and non-follower pension in small capitalization securities, as well as follower and non-follower pension funds in large capitalization securities. Then, I form quintile portfolios at the end of each month by sorting pension funds into five portfolios based on $R_{n}^{2}$. Next, I compute equally weighted posterior returns for each quintile portfolio. In this analysis, the returns of each pension fund correspond to the value-weighted returns of all small or large capitalization securities in the pension fund's portfolio. The results are reported in Table 4.11

Similarly, I examine the difference in performances between follower pension funds and non-follower pension funds only focusing on the share of pension funds' portfolios invested in developed markets and emerging markets. To perform this analysis, I estimate Equation (4.6) separately for developed and emerging markets. Next, I

identify follower and non-follower pension funds in the two markets by measuring $R_{n}^{2}$ - As before, I construct five quinitile portfolios based on $R_{n}^{2}$, and I compute equally weighted posterior returns for each quintile portfolio. The results are displayed in Table 4.12 and show that follower pension funds underperform non-follower pension funds by $0.23 \%$ on a monthly basis. This analysis integrates the findings of Section 4.4 and relies on the same method used in that section. 


\section{Table 4.11: Follower pension funds and portfolio performance by security size}

\begin{tabular}{|c|c|c|c|c|c|c|}
\hline \multirow{3}{*}{$\begin{array}{l}\text { Quintile } \\
\text { Avg. } R_{t}^{2}\end{array}$} & \multicolumn{6}{|c|}{ Panel A: Follower pension funds and portfolio performance - small securities } \\
\hline & (1) & $(2)$ & (3) & $(4)$ & $(5)$ & $5-1$ \\
\hline & 0.0011 & 0.0090 & 0.0390 & 0.1781 & 0.7264 & 0.7253 \\
\hline & \multicolumn{6}{|c|}{ Return month $t+1$ (\%) } \\
\hline Average & $\begin{array}{c}0.0212^{*} \\
(1.77)\end{array}$ & $\begin{array}{c}0.0327^{* *} \\
(2.18)\end{array}$ & $\begin{array}{c}0.0273^{* *} \\
(2.17)\end{array}$ & $\begin{array}{c}0.0170 \\
(1.16)\end{array}$ & $\begin{array}{l}0.0150 \\
(1.35)\end{array}$ & $\begin{array}{c}-0.0062 \\
(-0.87)\end{array}$ \\
\hline CAPM $\alpha_{M S C I-s m a l l-C a p}$ & $\begin{array}{c}-0.5024^{* *} \\
(-2.18)\end{array}$ & $\begin{array}{c}-0.4964^{* *} \\
(-2.17)\end{array}$ & $\begin{array}{c}-0.4995^{* *} \\
(-2.17)\end{array}$ & $\begin{array}{c}-0.5083^{* *} \\
(-2.22)\end{array}$ & $\begin{array}{c}-0.5026^{* *} \\
(-2.18)\end{array}$ & $\begin{array}{c}-0.0002 \\
(-0.03)\end{array}$ \\
\hline G4F $\alpha$ & $\begin{array}{c}-0.0222 \\
(-0.22)\end{array}$ & $\begin{array}{c}-0.0162 \\
(-0.16)\end{array}$ & $\begin{array}{c}-0.0195 \\
(-0.19)\end{array}$ & $\begin{array}{c}-0.0311 \\
(-0.30)\end{array}$ & $\begin{array}{c}-0.0210 \\
(-0.20)\end{array}$ & $\begin{array}{c}0.0012 \\
(0.15)\end{array}$ \\
\hline \multirow[t]{2}{*}{ NA3F $\alpha$} & $\begin{array}{c}-0.2119 \\
(-1.45)\end{array}$ & $\begin{array}{l}-0.2072 \\
(-1.40)\end{array}$ & $\begin{array}{c}-0.2089 \\
(-1.41) \\
\end{array}$ & $\begin{array}{c}-0.2177 \\
(-1.46)\end{array}$ & $\begin{array}{l}-0.2104 \\
(-1.44) \\
\end{array}$ & $\begin{array}{l}0.0015 \\
(0.19)\end{array}$ \\
\hline & \multicolumn{6}{|c|}{ Panel B: Follower pension funds and portfolio performance - large securities } \\
\hline \multirow[t]{2}{*}{ Avg. $R_{t}^{2}$} & 0.0005 & 0.0033 & 0.0118 & 0.0450 & 0.3641 & 0.3636 \\
\hline & \multicolumn{6}{|c|}{ Return month $t+1$ (\%) } \\
\hline Average & $\begin{array}{c}0.6876^{* * *} \\
(4.03)\end{array}$ & $\begin{array}{c}0.7031^{* * *} \\
(4.04)\end{array}$ & $\begin{array}{c}0.7197^{* * *} \\
(4.27)\end{array}$ & $\begin{array}{c}0.6948^{* * *} \\
(3.99)\end{array}$ & $\begin{array}{c}0.6646^{* * *} \\
(3.71)\end{array}$ & $\begin{array}{c}-0.0230 \\
(-0.57)\end{array}$ \\
\hline $\mathrm{CAPM} \alpha_{M S C I}$ & $\begin{array}{c}-0.1962^{*} \\
(-1.72)\end{array}$ & $\begin{array}{c}-0.1881 \\
(-1.62)\end{array}$ & $\begin{array}{c}-0.1582 \\
(-1.38)\end{array}$ & $\begin{array}{c}-0.1927^{*} \\
(-1.73)\end{array}$ & $\begin{array}{c}-0.2303^{*} \\
(-1.83)\end{array}$ & $\begin{array}{c}-0.0341 \\
(-0.80)\end{array}$ \\
\hline G4F $\alpha$ & $\begin{array}{l}0.0443 \\
(0.43)\end{array}$ & $\begin{array}{l}0.0562 \\
(0.58)\end{array}$ & $\begin{array}{l}0.0713 \\
(0.74)\end{array}$ & $\begin{array}{c}0.0499 \\
(0.55)\end{array}$ & $\begin{array}{l}0.0251 \\
(0.24)\end{array}$ & $\begin{array}{c}-0.0192 \\
(-0.39)\end{array}$ \\
\hline NA3F $\alpha$ & $\begin{array}{c}-0.2040 \\
(-1.27)\end{array}$ & $\begin{array}{l}-0.1994 \\
(-1.23)\end{array}$ & $\begin{array}{l}-0.1657 \\
(-1.05)\end{array}$ & $\begin{array}{l}-0.2005 \\
(-1.29)\end{array}$ & $\begin{array}{c}-0.2282 \\
(-1.29)\end{array}$ & $\begin{array}{c}-0.0241 \\
(-0.49)\end{array}$ \\
\hline
\end{tabular}

Notes: Each month between January 2009 and December 2018, I sort all securities with at least three trading funds into five quintiles based on their beginning-of-month market capitalization. I estimate Equation 4.6 for each pension fund $n^{\prime} s$ demand by limiting the sample to the quintile of securities with either the smallest market capitalization or the largest market capitalization. For each pension fund, I obtain $R_{n, t}^{2}$ from Equation 4.6. In Panel A, I present the summary statistics of $R_{n, t}^{2}$ : the indicator of the power of the all other pension funds' demand for small capitalization securities in predicting pension fund $n$ 's demand for small capitalization securities. $R_{n, t}^{2}$ measures the extent to which pension fund $n$ follows other pension funds, and it is estimated following the steps outlined in Section 4.3 Pension funds with high $R_{n, t}^{2}$ are defined as follower pension funds. Panel B presents the performance of pension fund quintile portfolios based on $R_{n, t}^{2}$. The quintile portfolios are formed at the end of each month from February 2009 to December 2018 and held for one month. I report the average posterior-month equally-weighted returns of the pension fund portfolios. Quintile 5 is the portfolio of follower pension funds. Quintile 1 is the portfolio of non-followers. I also estimate the risk-adjusted returns based on the CAPM and the Fama and French (2012) global market, size, value, and momentum factors (G4F) as well as North-American market, size and value factors (NA3F) in three separate regressions. The risk-adjusted returns are the intercept from a time-series regression of the quintile portfolios excess returns over the US one-month T-bill rate on the risk factors. The CAMP alphas for small cap securities are estimated using the MSCI AC World Small Cap Index as the market return. In Panel B, I present the summary statistics of $R_{n, t}^{2}$ and the quintile portfolio returns for follower and non-follower pension funds in large market capitalization securities. The CAMP alphas for large cap securities are estimated using the MSCI All Country World Index as the market return. All factors are converted into euro returns. The t-statistics are in parentheses and are computed using Newey-West standard errors with three lags. The * indicates statistical significance at the $10 \%$ level, ${ }^{* *}$ at the $\% 5$ percent, and ${ }^{* * *}$ at the $1 \%$ level. 
Table 4.12: Follower pension funds and portfolio performance by geographical area

\begin{tabular}{|c|c|c|c|c|c|c|}
\hline \multirow{3}{*}{$\begin{array}{l}\text { Quintile } \\
\text { Avg. } R_{t}^{2} \\
\end{array}$} & \multicolumn{6}{|c|}{ Panel A: Follower pension funds and portfolio performance - Developed } \\
\hline & (1) & $(2)$ & $(3)$ & $(4)$ & (5) & $5-1$ \\
\hline & 0.0002 & 0.0017 & 0.0064 & 0.0244 & 0.2424 & 0.2422 \\
\hline & \multicolumn{6}{|c|}{ Return month $t+1$ (\%) } \\
\hline Average & $\begin{array}{c}1.0126^{* * *} \\
(4.11)\end{array}$ & $\begin{array}{c}0.9806^{* * *} \\
(3.92)\end{array}$ & $\begin{array}{c}0.9444^{* * *} \\
(3.71)\end{array}$ & $\begin{array}{c}0.9762^{* * *} \\
(3.92)\end{array}$ & $\begin{array}{c}0.8934^{* * *} \\
(3.65)\end{array}$ & $\begin{array}{c}-0.1192^{* *} \\
(-2.54)\end{array}$ \\
\hline CAPM $\alpha_{M S C I}$ & $\begin{array}{c}-0.0066 \\
(-0.08)\end{array}$ & $\begin{array}{c}-0.0405 \\
(-0.52)\end{array}$ & $\begin{array}{c}-0.0786 \\
(-0.92)\end{array}$ & $\begin{array}{c}-0.0597 \\
(-0.73)\end{array}$ & $\begin{array}{c}-0.1288 \\
(-1.37)\end{array}$ & $\begin{array}{c}-0.1222^{* *} \\
(-2.33)\end{array}$ \\
\hline G4F $\alpha$ & $\begin{array}{l}0.1086 \\
(1.04)\end{array}$ & $\begin{array}{l}0.0684 \\
(0.64)\end{array}$ & $\begin{array}{l}0.0174 \\
(0.15)\end{array}$ & $\begin{array}{c}0.0458 \\
(0.40)\end{array}$ & $\begin{array}{l}0.0200 \\
(0.17)\end{array}$ & $\begin{array}{c}-0.0886 \\
(-1.65)\end{array}$ \\
\hline \multirow[t]{2}{*}{ NA3F $\alpha$} & $\begin{array}{c}-0.1563 \\
(-0.86)\end{array}$ & $\begin{array}{c}-0.1968 \\
(-1.05) \\
\end{array}$ & $\begin{array}{c}-0.2334 \\
(-1.19)\end{array}$ & $\begin{array}{l}-0.2260 \\
(-1.15)\end{array}$ & $\begin{array}{c}-0.2531 \\
(-1.35) \\
\end{array}$ & $\begin{array}{c}-0.0969^{*} \\
(-1.86)\end{array}$ \\
\hline & \multicolumn{6}{|c|}{ Panel B: Follower pension funds and portfolio performance - Emerging } \\
\hline \multirow[t]{2}{*}{ Avg. $R_{t}^{2}$} & 0.0010 & 0.0079 & 0.0340 & 0.1819 & 0.7509 & 0.7499 \\
\hline & \multicolumn{6}{|c|}{ Return month $t+1$ (\%) } \\
\hline Average & $\begin{array}{c}0.2818^{* * *} \\
(3.38)\end{array}$ & $\begin{array}{c}0.2547^{* * *} \\
(3.01)\end{array}$ & $\begin{array}{c}0.1787^{* *} \\
(2.29)\end{array}$ & $\begin{array}{c}0.1329^{* * *} \\
(2.78)\end{array}$ & $\begin{array}{c}0.0566^{* * *} \\
(2.63)\end{array}$ & $\begin{array}{c}-0.2251^{* * *} \\
(-2.96)\end{array}$ \\
\hline $\mathrm{CAPM} \alpha_{M S C I-E M}$ & $\begin{array}{c}-0.1729 \\
(-1.00)\end{array}$ & $\begin{array}{c}-0.2089 \\
(-1.19)\end{array}$ & $\begin{array}{c}-0.2518 \\
(-1.36)\end{array}$ & $\begin{array}{c}-0.2726 \\
(-1.47)\end{array}$ & $\begin{array}{c}-0.3024 \\
(-1.49)\end{array}$ & $\begin{array}{c}-0.1295^{* * *} \\
(-2.96)\end{array}$ \\
\hline G4F $\alpha$ & $\begin{array}{c}0.0476 \\
(0.42)\end{array}$ & $\begin{array}{l}0.0135 \\
(0.11)\end{array}$ & $\begin{array}{c}-0.0247 \\
(-0.21)\end{array}$ & $\begin{array}{l}-0.0230 \\
(-0.22)\end{array}$ & $\begin{array}{c}-0.0031 \\
(-0.03)\end{array}$ & $\begin{array}{r}-0.0507 \\
(-1.06)\end{array}$ \\
\hline NA3F $\alpha$ & $\begin{array}{l}-0.1731 \\
(-1.06)\end{array}$ & $\begin{array}{c}-0.2093 \\
(-1.28)\end{array}$ & $\begin{array}{c}-0.2513 \\
(-1.54)\end{array}$ & $\begin{array}{l}-0.2372 \\
(-1.59)\end{array}$ & $\begin{array}{l}-0.2145 \\
(-1.47)\end{array}$ & $\begin{array}{c}-0.0414 \\
(-0.76)\end{array}$ \\
\hline
\end{tabular}

Notes: At the beginning of each month between January 2009 and December 2018, I sort all securities with at least three trading funds into two groups based on their geographical area: developed and emerging markets. I estimate Equation (4.6) for each pension fund $n^{\prime} s$ demand by limiting the sample to either securities from developed markets or securities from emerging markets. For each pension fund I obtain $R_{n, t}^{2}$ from Equation 4.6. In Panel A, I present the summary statistics of $R_{n, t}^{2}$ : the indicator of the power of the all other pension funds' demand for developed markets securities in predicting pension fund $n$ 's demand for developed markets securities. $R_{n, t}^{2}$ measures the extent to which pension fund $n$ follows other pension funds, and it is estimated following the steps outlined in Section 4.3 Pension funds with high $R_{n, t}^{2}$ are defined as follower pension funds. Panel B presents the performance of pension fund quintile portfolios formed based on $R_{n, t}^{2}$. The quintile portfolios are formed at the end of each month from February 2009 to December 2018 and are held for one month. I report the average posterior-month equally weighted returns of the pension fund portfolios. Quintile 5 is the portfolio of follower pension funds. Quintile 1 is the portfolio of non-followers. I also estimate the risk-adjusted returns based on the CAPM and the Fama and French (2012) global market, size, value, and momentum factors $(\mathrm{G} 4 \mathrm{~F})$ as well as North-American market, size and value factors (NA3F) in three separate regressions. The risk-adjusted returns are the intercept from a time-series regression of the quintile portfolios excess returns over the US one-month T-bill rate on the risk factors. The CAMP alphas for developed markets securities are estimated using the MSCI All Country World Index as the market return. In Panel B, I present the summary statistics of $R_{n, t}^{2}$ and the quintile portfolio returns for follower and non-follower pension funds in emerging market securities. The CAMP alphas for emerging market securities are estimated using the MSCI Emerging Markets Index as the market return. All factors are converted into euro returns. The t-statistics are in parentheses and are computed using Newey-West standard errors with three lags. The * indicates statistical significance at the $10 \%$ level, ${ }^{* *}$ at the $\% 5$ percent, and ${ }^{* * *}$ at the $1 \%$ level. 


\section{A.2 Predictive regression of pension funds' alpha}

In this appendix, I study the relation between size and a pension fund's future performance by replicating Table 4.6 and excluding the type of pension fund and herding that are variables correlated with pension fund size.

Table 4.13: Predictive regression of pension funds' alpha

\begin{tabular}{lc}
\hline \hline & $\mathrm{G} 4 \mathrm{~F} \alpha_{t}$ \\
\hline Log sizet -1 & $0.0193^{*}$ \\
& $(1.85)$ \\
Turnovert -1 & $-0.0021^{* *}$ \\
& $(-2.47)$ \\
Flowt -1 & $-0.0016^{* *}$ \\
& $(-2.31)$ \\
Constant & 0.1598 \\
& $(1.01)$ \\
\hline \hline Observations & 3,265 \\
$R^{2}$ & 0.199 \\
\hline \hline
\end{tabular}

Notes: The table presents the coefficients from a predictive pooled OLS that estimates the relation between the future 4 -factor alpha (in \%) of pension funds and pension fund characteristics. The dependent variable is the monthly global four-factor alpha (in \%) that is estimated with rolling-window regressions over the previous three years of the excess return (over the US one-month T-bill rate) of each pension fund on the global market, size, value, and momentum factors from Fama and French $(2012)$. Control variables are the previous-month pension fund size, previous-month turnover, and previous-month flow. The model is estimated with month fixed effects and standard errors clustered at the pension fund level. The t-statistics are in parenthesis. The * indicates statistical significance at the $10 \%$ level, ** at the $5 \%$ level, and $* * *$ at the $1 \%$ level.

\section{A.3 Determinants of herding including the number of secu- rities in the portfolio}

In this subsection, I replicate the results of Table 4.7 by including the number of securities held by each pension fund among the independent variables in the regression. 
Table 4.14: Determinants of herding - number of securities held

\begin{tabular}{|c|c|c|c|c|c|c|c|c|}
\hline & \multicolumn{2}{|c|}{ Developed markets } & \multicolumn{2}{|c|}{ Emerging markets } & \multicolumn{2}{|c|}{ Large cap } & \multicolumn{2}{|c|}{ Small cap } \\
\hline & $\begin{array}{l}(1) \\
R_{n, t}^{2}\end{array}$ & $\begin{array}{c}(2) \\
\text { Follower }\end{array}$ & $\begin{array}{l}(3) \\
R_{n, t}^{2}\end{array}$ & $\begin{array}{c}(4) \\
\text { Follower }\end{array}$ & $\begin{array}{l}(5) \\
R_{n, t}^{2}\end{array}$ & $\begin{array}{c}(6) \\
\text { Follower }\end{array}$ & $\begin{array}{l}(7) \\
R_{n, t}^{2}\end{array}$ & $\begin{array}{c}(8) \\
\text { Follower }\end{array}$ \\
\hline Corporate Pf. & $\begin{array}{l}0.005 \\
(0.27)\end{array}$ & $\begin{array}{l}0.270 \\
(0.86)\end{array}$ & $\begin{array}{l}0.094^{*} \\
(1.76)\end{array}$ & $\begin{array}{c}0.896^{* *} \\
(2.07)\end{array}$ & $\begin{array}{l}0.061^{* *} \\
(2.59)\end{array}$ & $\begin{array}{c}0.698^{* *} \\
(2.16)\end{array}$ & $\begin{array}{l}-0.017 \\
(-0.39)\end{array}$ & $\begin{array}{l}0.089 \\
(0.28)\end{array}$ \\
\hline Industry Pf. & $\begin{array}{l}0.007 \\
(0.30)\end{array}$ & $\begin{array}{l}0.267 \\
(0.73)\end{array}$ & $\begin{array}{l}0.018 \\
(0.38)\end{array}$ & $\begin{array}{l}0.131 \\
(0.32)\end{array}$ & $\begin{array}{l}0.027 \\
(1.21)\end{array}$ & $\begin{array}{l}0.400 \\
(1.16)\end{array}$ & $\begin{array}{l}-0.003 \\
(-0.08)\end{array}$ & $\begin{array}{l}0.132 \\
(0.45)\end{array}$ \\
\hline Log size & $\begin{array}{l}-0.008 \\
(-1.47)\end{array}$ & $\begin{array}{l}-0.222^{*} \\
(-1.73)\end{array}$ & $\begin{array}{c}-0.062^{* * *} \\
(-3.22)\end{array}$ & $\begin{array}{c}-0.681^{* * * *} \\
(-4.83)\end{array}$ & $\begin{array}{c}-0.018^{* *} \\
(-2.10)\end{array}$ & $\begin{array}{c}-0.319^{* *} \\
(-2.41)\end{array}$ & $\begin{array}{c}-0.034^{* *} \\
(-2.31)\end{array}$ & $\begin{array}{l}-0.216 \\
(-1.37)\end{array}$ \\
\hline No. securities & $\begin{array}{l}-0.000^{*} \\
(-1.78)\end{array}$ & $\begin{array}{c}-0.000^{* *} \\
(-2.50)\end{array}$ & $\begin{array}{c}-0.000^{*} \\
(-1.99)\end{array}$ & $\begin{array}{l}-0.000 \\
(-1.50)\end{array}$ & $\begin{array}{c}-0.000^{*} \\
(-1.90)\end{array}$ & $\begin{array}{c}-0.000^{* *} \\
(-2.16)\end{array}$ & $\begin{array}{c}-0.000^{* * *} \\
(-5.32)\end{array}$ & $\begin{array}{c}-0.001^{* * *} \\
(-4.38)\end{array}$ \\
\hline Turnover & $\begin{array}{c}-0.153^{* * *} \\
(-4.68)\end{array}$ & $\begin{array}{c}-18.674^{* * *} \\
(-4.71)\end{array}$ & $\begin{array}{c}-0.328^{*} \\
(-1.75)\end{array}$ & $\begin{array}{l}-3.927^{*} \\
(-1.67)\end{array}$ & $\begin{array}{c}-0.251^{* * *} \\
(-4.39)\end{array}$ & $\begin{array}{c}-16.131^{* * *} \\
(-4.80)\end{array}$ & $\begin{array}{c}-0.254^{* * *} \\
(-2.90)\end{array}$ & $\begin{array}{l}-2.605^{*} \\
(-1.81)\end{array}$ \\
\hline Flow & $\begin{array}{l}0.029 \\
(1.64)\end{array}$ & $\begin{array}{l}-0.476 \\
(-0.19)\end{array}$ & $\begin{array}{l}0.017 \\
(0.19)\end{array}$ & $\begin{array}{l}0.115 \\
(0.16)\end{array}$ & $\begin{array}{l}0.048 \\
(1.58)\end{array}$ & $\begin{array}{l}-2.309 \\
(-1.05)\end{array}$ & $\begin{array}{l}0.052 \\
(1.26)\end{array}$ & $\begin{array}{l}1.187^{*} \\
(1.89)\end{array}$ \\
\hline $\operatorname{Return}_{t-1}$ & $\begin{array}{l}0.321 \\
(1.26)\end{array}$ & $\begin{array}{l}1.613 \\
(0.51)\end{array}$ & $\begin{array}{l}-0.435 \\
(-0.73)\end{array}$ & $\begin{array}{l}0.365 \\
(0.07)\end{array}$ & $\begin{array}{l}-0.109 \\
(-0.22)\end{array}$ & $\begin{array}{l}-2.199 \\
(-0.55)\end{array}$ & $\begin{array}{l}-0.122 \\
(-0.21)\end{array}$ & $\begin{array}{c}0.651 \\
(0.16)\end{array}$ \\
\hline Constant & $\begin{array}{c}0.160^{* * *} \\
(2.69) \\
\end{array}$ & $\begin{array}{l}1.776 \\
(1.17) \\
\end{array}$ & $\begin{array}{c}1.174^{* * *} \\
(4.90) \\
\end{array}$ & $\begin{array}{c}7.351^{* * *} \\
(4.36) \\
\end{array}$ & $\begin{array}{c}0.313^{* * *} \\
(3.09) \\
\end{array}$ & $\begin{array}{c}3.026^{* *} \\
(1.97) \\
\end{array}$ & $\begin{array}{c}0.687^{* * *} \\
(3.66) \\
\end{array}$ & $\begin{array}{l}1.988 \\
(0.99) \\
\end{array}$ \\
\hline $\begin{array}{l}\text { Observations } \\
R^{2}\end{array}$ & $\begin{array}{l}5,273 \\
0.059\end{array}$ & 5,273 & $\begin{array}{l}4,500 \\
0.196\end{array}$ & 4,418 & $\begin{array}{l}5,244 \\
0.112\end{array}$ & 5,244 & $\begin{array}{l}4,732 \\
0.166\end{array}$ & 4,732 \\
\hline Pseudo $R^{2}$ & & 0.088 & & 0.183 & & 0.102 & & 0.146 \\
\hline
\end{tabular}

Notes: The table presents in columns (1), (3), (5), and (7) the estimated coefficients from pooled OLSs of $R_{n}^{2}$, the follower measure, on pension fund characteristics. Also, the table presents in columns (2), (4), (6), and (8) the estimate coefficients from logit regressions of "Follower" that is a binary variable that equals one if pension fund $n$ falls within the $5^{t h}$ quintile of $R_{n}^{2}$ on pension fund characteristics. The types of pension funds are the industry-wide pension fund and the corporate pension fund, and the omitted category is pension asset management firms. Log size is the natural logarithm of the total equity portfolio of the pension fund. Turnover is the turnover ratio of the pension funds computed as in Brennan and Cao (1997). Flow is the pension fund flow in the previous month. Return $t_{t-1}$ is the previous month's gross return of the pension fund. All models are estimated with month fixed effects and standard errors clustered at the pension fund level. The t-statistics are in parentheses, The * indicates statistical significance at the $10 \%$ level, ${ }^{* *}$ at the $\% 5$ level, and ${ }^{* * *}$ at the $1 \%$ level. 


\section{A.4 Determinants of herding including piecewise-linear seg- ments of size}

The Dutch occupational pension sector is characterized by a few very large pension funds. Thus, outliers might drive the relation between herding and size. In this section, I study the relation between herding and size by using piecewise-linear segments of size as independent variables replacing log size in Table 4.6.

First, size percentiles are defined based on the log of assets under management each month. Second, low, mid and high size percentiles are defined as follows

$$
\begin{gathered}
\text { Low.size }_{t}=\min \left(\text { Percentile }_{\text {size }, t}, 0.2\right) \\
\text { Mid.size }_{t}=\min \left(\max \left(\text { Percentile }_{\text {size }, t}-0.2,0\right), 0.6\right) \\
\text { Large.size }_{t}=\max \left(\text { Percentile }_{\text {size }, t}-0.8,0\right)
\end{gathered}
$$

Table 4.15 shows that the coefficients of all size segment are negative, in line with the log size measure. Mid and large pension funds seem to contribute more in capturing the relation between size and pension fund herding. Large pension funds in the quantile of mid and large pension fund herd less than small pension funds in the same quantiles. Within the group of small pension funds, smaller pension funds herd more than larger pension funds only in emerging markets. The same does not hold in developed markets, or when I separate between large and small cap stocks. 
Table 4.15: Determinants of herding with piecewise size segments

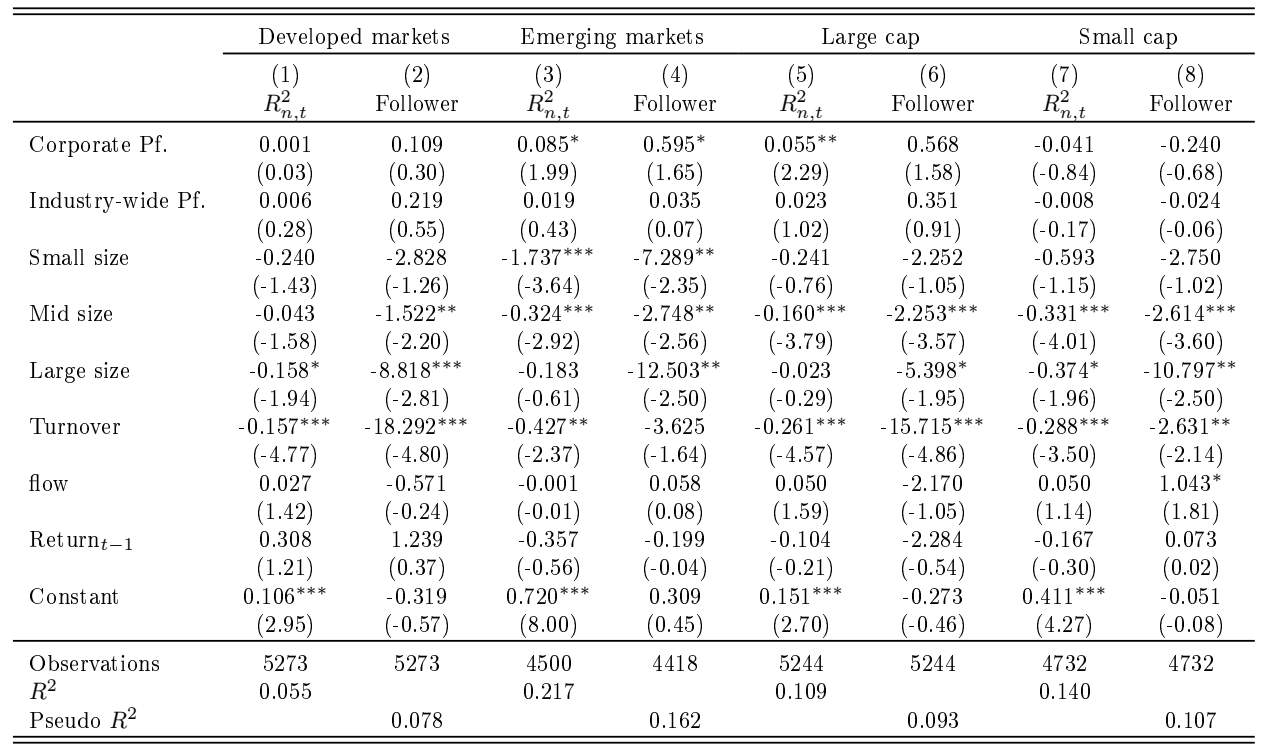

Notes: This table presents columns (1), (3), (5), and (7) the estimated coefficients from pooled OLSs of $R_{n}^{2}$, the follower measure, on pension fund characteristics. Also, the table presents in columns (2), (4), (6), and (8) the estimate coefficients from logit regressions of "Follower" that is a binary variable that equals one if pension fund $n$ falls within the $5^{\text {th }}$ quintile of $R_{n}^{2}$ on pension fund characteristics. All models are estimated with month fixed effects and standard errors clustered at the pension fund level. The t-statistics are in parentheses, The * indicates statistical significance at the $10 \%$ level, $* *$ at the $\% 5$ level, and *** at the $1 \%$ level. 


\section{Chapter 5}

\section{Summary of findings}

Since Jensen and Meckling (1976) and Myers (1977), financial economists have extensively studied the conflicts of interests and misalignments of incentives in the management of corporations. See Shleifer and Vishny (1997) and Zingales (2000) for surveys of the literature. Similar problems arise in the management of financial institutions too Allen (2001)). In this dissertation, I show that the large number of stakeholders involved in a pension fund generates conflicts of interests and misalignments of incentives that affect investment policy. The design of a pension fund's investment policy appears to not be just the result of a mean variance portfolio optimization. Instead, it is also affected by the behavior of pension fund stakeholders, in particular trustees, advisors, and peers.

Chapter 2 shows that the trustees of corporate pension funds consider their age and their constituencies' interests when they design the strategic asset allocation. As a consequence, trustees design this allocation in a way that may not be completely in line with beneficiaries' characteristics and interests. Individuals delegate pension accumulation to pension funds either because they are required to do so by the law or because they lack the expertise to implement saving and investment decisions autonomously [ However, by delegating the management of their retirement savings to a third party, beneficiaries of a pension fund are exposed to conflicts of interests.

\footnotetext{
${ }^{1}$ Pension funds reduce the costs of investing by benefiting from economies of scale associated with specialization in acquiring financial expertise and accessing financial markets (Bovenberg et al. (2007)).
} 
These conflicts materialize when the trustees value private interests over beneficiaries' interests in managing the pension fund (Lakonishok et al. (1992a), Goyal and Wahal (2008)). The fact that trustees consider their age and their constituencies' interests when they design the strategic asset allocation can foster these conflicts of interests.

Chapter 3 shows that external advisors such as actuaries and asset management firms can influence the strategic asset allocation of the pension funds irrespective of their characteristics, and despite the fact that these advisors have no formal decisionmaking power. This influence is particularly strong in asset classes that require high expertise and that generate income from high fees for the external advisors such as real estate, private equity, hedge funds, and commodities. This influence can have a negative effect on pension funds' cost structures and returns if it leads them to select strategic asset allocations that are not in line with their liability structures, funding ratios, sophistication levels, or organizational structures. Trustees contract actuaries and asset management firms to assist in the design and implementation of the investment policy. However, these advisors have different incentives than trustees and beneficiaries. On the one hand, advisors aim at maximizing their profits and their contract length. On the other hand, trustees' duty and beneficiaries' interests are efficient and cost-effective management of the pension fund. This misalignment of incentives affects the investment policy of pension funds.

Chapter 4 shows that pension funds herd into and out of the same securities over time. Herding is related to the search for information, as small pension funds that have less resources to invest in researching are more likely to herd. However, pension funds that herd underperform pension funds that do not herd. This performance indicates that inferring information from others' trades does not add value. Moreover, herding is related to the fear of underperforming peers, as pension funds consistently herd over time irrespective of their past performance. By following others, the asset managers of pension funds can reduce their responsibility in the event of poor performance.

In this dissertation, I show that the characteristics of trustees and their stakeholder representation influence their investment decisions; advisors influence the strategic asset allocation, and peers influence the security selection. These three findings have 
policy implications for pension funds, the regulator, and for financial stability. 


\section{Chapter 6}

\section{Research impact}

\subsection{Implications for pension funds}

The findings of this dissertation have direct implications for pension funds. Chapter 2 indicates that Dutch pension funds still have room to improve in terms of both the age and gender diversities of their boards. The 2014 Code of Dutch Pension Funds is a good step in promoting diversity. However, only 40 percent of the pension funds have at least one trustee younger than 40 years old on their board. Moreover, 40 percent of the pension funds still have no female trustee. More diversity contributes to a better representation of all groups of beneficiaries and in turn further improves the board's decision-making in which its characteristics play less of a role.

The findings of Chapters 3 call for a stronger monitoring of external advisors such as actuaries and asset managers by the board of trustees to mitigate the potential misalignment of incentives. First, stronger monitoring can be achieved by requiring advisors to provide more transparency on their activities and potential conflicts of interests. Second, monitoring can be enhanced by appointing trustees that are knowledgeable in asset management and investments such that an adequate countervailing power is present in the pension fund's board. Arguably, the board of trustees should be able to question and critically examine services provided by the advisors. Therefore, boards could strive to find investment experts when filling vacancies.

Chapter 4 provides evidence of herd behavior in the equity investments of pen- 
sion funds. Career concerns of asset managers can encourage herd behavior. These concerns create a misalignment of incentives between asset managers and trustees, who aim to identify highly skilled asset managers. Hence, trustees should be aware of these herding tendencies when delegating the security selection to third parties. Trustees should require sufficient transparency from the asset management firms on their process of selecting securities. Moreover, similar herding tendencies might also occur in the strategic decisions made by the board.

\subsection{Implications for the pension regulator}

Although there is no statutory obligation for employers to offer a pension plan in the Netherlands, it is de facto the norm. Therefore, nearly all employees automatically enroll in an occupational pension plan. Once they have joined the pension plan offered by their employer, they are not allowed to move their contributions, unless they decide to change jobs and transfer their accrued pension benefits to another pension fund. To safeguard the interests of all stakeholders, especially beneficiaries, the regulator imposes that all stakeholders (participants, retirees, and sponsors) are represented on the board of trustees. Article 100 of the Dutch Pension Act establishes that each board of trustees should have an equal number of representatives of the employer and of the beneficiaries. Within limits, each pension fund can decide how many of the representatives of the beneficiaries will be elected by the participants or by the pensioners 1 In addition, pension funds can decide to have independent trustees. These decisions generate dispersion in stakeholder representation. As a consequence, the sponsor representatives are often in a dominant position compared to the more fragmented representatives of the beneficiaries. Moreover, the law does not indicate guidelines concerning age or gender representation. In fact, in many boards senior and male participants are overrepresented with respect to female and young participants.

\footnotetext{
${ }^{1}$ There is a limit to the number of trustees that represent retirees. This is 25 percent of the board's seats. However, if the number of participants is less than 10 percent of the sum of the number of participants and pensioners, then pensioner representatives can occupy more seats than employee representatives. See Article 102, sub 2, of the Dutch pension act.
} 
The effect of trustees' characteristics on strategic asset allocations documented in Chapter 2 can be alleviated with two governance requirements. First, greater board diversity could be required by law. In fact, the Code of Dutch Pension Funds is applied only under the comply-or-explain principle. This non-mandatory nature of the Code may weaken the commitment of pension funds to comply with it. Second, to improve the balance of power among stakeholders' representatives, a number of independent trustees could be required. These are external experts that compete in the job market for trustees (Besley and Prat (2003)). Pension funds have increasingly hired independent trustees in recent years. However, only a few pension funds have at least one independent trustee on their boards. Having more independent trustees can reduce the conflict of interest between trustees and beneficiaries.

Formally, external advisors have no decision-making power on the asset allocations of pension funds. However, Chapter 3 shows that advisors influence the investment decisions of their clients. This result calls for greater transparency between pension funds and advisors, and stronger monitoring of the advisors by the board. More transparency can be achieved by requiring advisors to declare potential conflict of interests, such as actuaries or investment consultants that are part of a group that also offers some of the investment products that are advised. To enhance monitoring, pension funds could develop a standardized assessment tool for decisions on investment policy and to report its outcome to the regulator. For example, when variations to the investment policy are approved, trustees should report the estimated changes in the risk profile and their costs. The regulator could use the additional reporting to better assess pension funds' strategic asset allocations and express concerns to the board of trustees on investment decisions that do not fully reflect the sophistication level of the pension fund.

Chapter 4 shows that there is herding in pension funds' equity investments. Herding is primarily related to the size and hence to the organizational structure and resources of a pension fund. Herding is motivated by the search for information and career concerns of the asset managers. Furthermore, if pension funds design similar benchmarks, these can incentivize herding. Therefore, the regulator could require 
pension funds to report more information on the composition of a proprietary benchmark and on the criteria adopted to construct such a benchmark. The regulator could also require pension funds to provide details on the investment mandates. For example, how much freedom the asset management firm has in overweighting some sector, factors, or geographical areas with respect to others. Moreover, pension funds could be required to report a list of their investment beliefs to the regulator on a regular basis (these are generally included in the pension fund's investment plan) so that it can assess the deviation of the actual equity portfolio from these beliefs. The regulator could use the additional reporting to assess how the security selection deviates from investment beliefs of the pension fund and that could signal possible herding tendencies that can negatively affect performance.

\subsection{Implications for financial stability}

The findings of this dissertation also have implications for financial stability. Because of the common-advisor effect and herding, pension funds might develop portfolios that become increasingly exposed to common risk factors over time. Especially if pension funds develop similar SAAs or apply similar interest rate hedging strategies. Consequently, the probability of pension funds going into distress at the same time can increase. In fact, if all pension funds hold a similarly diversified portfolio, a common idiosyncratic shock may disrupt all the pension funds simultaneously (Ibragimov et al. (2011) and Beale et al. (2011)).

Apart from the concerns for financial stability, if a sufficient number of pension funds are in distress at the same time, it puts them in a strong position to argue for changes in the regulation. One practical example of this group pressure on the regulator can be seen from the recent discussion around the possibility of temporarily lowering the minimum required funding ratio of Dutch pension funds from $104.3 \%$ to $100 \%$ in order to avoid reductions of accrued benefits.2 Following this discussion,

\footnotetext{
${ }^{2}$ See: https://www.ipe.com/reports/netherlands-funds-delay-trouble/10043936.artic 
trustees of different pension funds might have an incentive to design portfolios that are more alike. For examples of non-competitive behavior among financial institutions see Poitevin (1989) and Dutta and Madhavan (1997).

\subsection{Implications for the pension reform}

After years of negotiations, the Dutch government has reached an agreement on pension reform with the main organisations representing employees and employers. The pension reform is expected to come into force by 1 January 2023 with a transition period from 2023 to 2027, and will fundamentally reshape the system of occupational pensions. In particular, it entails a new pension contract, changes to the future pension accruals, the contribution rate, and a new fiscal framework. A new type of collective DC contract will be an option available to pension funds, in which there will be a collective investment pool with no individual accounts. A "solidarity reserve" will be built to smooth inter-generational fluctuations in investment returns. On an annual basis the investment results (after any transfer to or from the solidarity reserve) will be allocated to individual members' notional accounts according to the members' age-dependent risk profiles. Being a DC contract, contributions will be fixed and the level of benefits paid to a member will not be guaranteed, but they will be adjusted up or down annually based on investment and demographic experience. The change in the pension contracts means that the tax-favored DB accruals would cease, and all future accruals will have to be in individual-account DC plans or in collective DC plans. There will be a flat annual pension accrual that is independent from the age of the member age, a major difference compared to the current setting. Under the new fiscal framework, tax-favored total annual contributions to a member's pension account, excluding risk premiums and administrative charges, will be capped at a government-specified percentage of the member's pensionable earnings, which will initially be between $30 \%$ and $33 \%$. This rate is based on the targeting of a replacement ratio of $75 \%$ after 40 years and it will be subject to change every five years. 
The results of this dissertation remain relevant in the new setting, albeit to a lesser extent or somewhat differently. In the new system, a board of trustees continues to be in charge of overall decision making. Therefore, trustees' characteristics may still influence the pension fund investment decisions. However, instead of a risk aversion at the pension fund level, the risk aversion per cohort should be taken into account under the new pension contract. Therefore, it is reasonable to expect a lower trustee effect. Furthermore, because the investment risk is shifted to the individuals, the employer representative effect should reduce in a DC setting. In the new system the common advisor effect may still play a role, as the system continues to rely on the services of third parties. Hence the multiple layers of delegation will not disappear. If pension funds continue to use the same advisory firms to decide on SAA, asset and liability management or to measure the risk attitude of participants, the impact of commonadvisor effects will not disappear. The same holds for herding. Asset management firms will still be in charge of security selection and hence expose pension funds to herding tendencies.

\subsection{Future research}

This dissertation highlights that advisors such as asset managers and actuaries have significant influence on the design of the investment policy although they do not hold formal decision-making power. An additional type of advisors, which are also directly involved in the design of the investment policy and that are not discussed here, are investment consultants. Investment consultants provide advice on the asset class selection, assess return expectations (Andonov and Rauh (2019)), and the hire of asset management firms (Rossi et al. (2018)). However, a lack of detailed reporting on investment consultants has prevented extensive academic research on what drives pension funds to select or dismiss these advisers. In future research, hand-collected information on the contract details of investment consultants can be used to answer this question. Specialized investment consultants might be hired as a consequence of a pension fund's decision to enter a new asset class, for example, infrastructures. 
In this case, pension funds might seek specific expertise that they do not possess in house. Hiring and dismissing investment consultants might be related to the past performance of the advised asset managers. For example, pension funds might hire a new consultant or replace an existing one to seek more skilled asset managers or to define a larger universe of asset managers to choose from. Alternatively, pension funds trustees might rely on the services of investment consultants regardless the quality of their advice to reduce their responsibility in the event of poor performance (Goyal and Wahal (2008)).

Future research can also examine the relation between pension funds' portfolio similarities and financial stability. For example, can the herding tendencies of pension funds lead to fire sales in the equity or bond markets? Answering this question means empirically testing whether pension funds' trading behavior and hedging decisions stabilize or destabilize financial markets (Domanski et al. (2017) and Greenwood et al. (2018)).

My research on pension fund herding can be extended to sustainable and responsible investments. In the past decade, sustainable and responsible investments have grown in volume globally, and at the start of 2018 stood at $\$ 30.7$ trillion (SIF 2018). Sustainable and responsible investments have attracted the interests of institutional investors, and especially pension funds that are increasingly integrating environmental, social, and governance (ESG) into their process of selecting securities. For example, as of April 2019 more than 2,000 institutional investors representing $\$ 80$ trillion assets under management have signed on to the United Nations-supported Principles for Responsible Investing (UNPRI) Initiative ${ }^{3}$ These facts pose three research questions. First, are institutional investors following each other into sustainable investments and out of unsustainable investments? Second, if they indeed follow each other why do they do so? Third, do sustainability criteria affect the performance of institutional investors?

\footnotetext{
${ }^{3}$ https: / /www.unpri.org
} 


\section{Bibliography}

Adams, R. B. and Ferreira, D. (2009). Women in the boardroom and their impact on governance and performance. Journal of Financial Economics, 94(2):291-309.

Adams, R. B., Hermalin, B. E., and Weisbach, M. S. (2010). The role of boards of directors in corporate governance: A conceptual framework and survey. Journal of Economic Literature, 48(1):58-107.

Ahern, K. R. and Dittmar, A. K. (2012). The changing of the boards: The impact on firm valuation of mandated female board representation. Quarterly Journal of Economics, 127(1):137-197.

Alesina, A. and Cukierman, A. (1990). The politics of ambiguity. Quarterly Journal of Economics, 105(4):829-850.

Alesina, A., Londregan, J., and Rosenthal, H. (1993). A model of the political economy of the united states. American Political Science Review, 87(1):12-33.

Allen, F. (2001). Do financial institutions matter? Journal of Finance, 56(4):11651175 .

Amir, E., Guan, Y., and Oswald, D. (2010). The effect of pension accounting on corporate pension asset allocation. Review of Accounting Studies, 15(2):345-366.

Ammann, M. and Ehmann, C. (2017). Is governance related to investment performance and asset allocation? Empirical evidence from swiss pension funds. Swiss Journal of Economics and Statistics, 153(3):293-339.

Andonov, A., Bauer, R., and Cremers, M. (2012). Can large pension funds beat the market? Asset allocation, market timing, security selection and the limits of liquidity. Working Paper, Available at https://ssrn.com/abstract=1885536.

Andonov, A., Bauer, R., and Cremers, M. (2017). Pension fund asset allocation and liability discount rates. Review of Financial Studies, 30(8):2555-2595.

Andonov, A., Eichholtz, P., and Kok, N. (2015). Intermediated investment management in private markets: Evidence from pension fund investments in real estate. Journal of Financial Markets, 22:73-103. 
Andonov, A., Hochberg, Y. V., and Rauh, J. D. (2018a). Political representation and governance: Evidence from the investment decisions of public pension funds. Journal of Finance, 73(5):2041-2086.

Andonov, A., Kräussl, R., and Rauh, J. (2018b). The subsidy to infrastructure as an asset class. Available at https://ssrn.com/abstract=3245543

Andonov, A. and Rauh, J. D. (2019). The return expectations of institutional investors. Available at https://papers.ssrn.com/sol3/papers.cfm?abstract_i $\mathrm{d}=3091976$.

Avery, C. N. and Chevalier, J. A. (1999). Herding over the career. Economics Letters, 63(3):327-333.

Banerjee, A. V. (1992). A simple model of herd behavior. Quarterly Journal of Economics, 107(3):797-817.

Barberis, N. and Shleifer, A. (2003). Style investing. Journal of Financial Economics, 68(2):161-199.

Barbon, A., Di Maggio, M., Franzoni, F., and Landier, A. (2019). Brokers and order flow leakage: Evidence from fire sales. Journal of Finance, 74(6):2707-2749.

Bauer, R., Bonetti, M., and Broeders, D. (2020). Common advisor effect in strategic asset allocations. Working Paper, Available at https://papers.ssrn.com/sol3 /papers.cfm?abstract_id=3279390.

Bauer, R., Cremers, M., and Frehen, R. (2010). Pension fund performance and costs: Small is beautiful. Available at https://papers.ssrn.com/sol3/papers.cfm?a bstract_id=965388\&download=yes

Bauer, R., Hoevenaars, R., and Steenkamp, T. (2006). Asset liability management. In The oxford handbook of pensions and retirement income, pages 417-40. Oxford University Press.

Beale, N., Rand, D. G., Battey, H., Croxson, K., May, R. M., and Nowak, M. A. (2011). Individual versus systemic risk and the regulator's dilemma. Proceedings of the National Academy of Sciences, 108(31):12647-12652.

Beck, N., Gleditsch, K. S., and Beardsley, K. (2006). Space is more than geography: Using spatial econometrics in the study of political economy. International studies quarterly, 50(1):27-44.

Bennett, J. A., Sias, R. W., and Starks, L. T. (2003). Greener pastures and the impact of dynamic institutional preferences. Review of Financial Studies, 16(4):1203-1238.

Benzoni, L., Collin-Dufresne, P., and Goldstein, R. S. (2007). Portfolio choice over the life-cycle when the stock and labor markets are cointegrated. The Journal of Finance, 62(5):2123-2167. 
Bernasek, A. and Shwiff, S. (2001). Gender, risk, and retirement. Journal of economic issues, $35(2): 345-356$.

Besley, T. J. and Prat, A. (2003). Pension fund governance and the choice between defined benefit and defined contribution plans. CEPR Discussion Paper.

Bikhchandani, S., Hirshleifer, D., and Welch, I. (1992). A theory of fads, fashion, custom, and cultural change as informational cascades. Journal of Political Economy, 100(5):992-1026.

Bikhchandani, S. and Sharma, S. (2000). Herd behavior in financial markets. IMF Staff papers, 47(3):279-310.

Bikker, J. A., Broeders, D. W., Hollanders, D. A., and Ponds, E. H. (2012). Pension funds' asset allocation and participant age: A test of the life-cycle model. Journal of Risk and Insurance, 79(3):595-618.

Bikker, J. A. and De Dreu, J. (2009). Operating costs of pension funds: The impact of scale, governance, and plan design. Journal of Pension Economics and Finance, $8(1): 63-89$.

Binfare, M., Brown, G. W., Harris, R. S., and Lundblad, C. T. (2018). How do financial expertise and networks affect investing? evidence from the governance of university endowments. Working Paper, Available at https://www.rsm.nl/filea dmin/home/Department_of_Finance__VG5_/PAM2018/Final_Papers/Matteo_B infare.pdf,

Black, D. (1948). On the rationale of group decision-making. Journal of Political Economy, 56(1):23-34.

Blake, D., Rossi, A. G., Timmermann, A., Tonks, I., and Wermers, R. (2013). Decentralized investment management: Evidence from the pension fund industry. Journal of Finance, 68(3):1133-1178.

Blake, D., Sarno, L., and Zinna, G. (2017). The market for lemmings: The herding behavior of pension funds. Journal of Financial Markets, 36:17-39.

Blome, S., Fachinger, K., Franzen, D., Scheuenstuhl, G., and Yermo, J. (2007). Pension fund regulation and risk management: Results from an alm optimisation exercise. Private Pensions Series Protecting Pensions Policy Analysis and Examples from OECD Countries: Policy Analysis and Examples from OECD Countries, 8:161-212.

Bodie, Z., Marcus, A. J., and Merton, R. C. (1988). Defined Benefit versus Defined Contribution Pension Plans: What are the Real Trade-offs?, pages 139-162. University of Chicago Press. 
Bodie, Z., Merton, R. C., and Samuelson, W. F. (1992). Labor supply flexibility and portfolio choice in a life cycle model. Journal of Economic Dynamics and Control, 16(3-4):427-449.

Boeri, T., Bovenberg, L., Coeuré, B., and Roberts, A. (2006). Dealing with the new giants: Rethinking the role of pension funds. International Center for Monetary and Banking Studies.

Boon, L. N., Briere, M., and Rigot, S. (2018). Regulation and pension fund risktaking. Journal of International Money and Finance, 84:23-41.

Bouwman, C. H. (2011). Corporate governance propagation through overlapping directors. Review of Financial Studies, 24(7):2358-2394.

Bovenberg, L., Koijen, R., Nijman, T., and Teulings, C. (2007). Saving and investing over the life cycle and the role of collective pension funds. De Economist, $155(4): 347-415$.

Bradley, D., Pantzalis, C., and Yuan, X. (2016). The influence of political bias in state pension funds. Journal of Financial Economics, 119(1):69-91.

Brennan, M. J. and Cao, H. H. (1997). International portfolio investment flows. Journal of Finance, 52(5):1851-1880.

Broeders, D., Chen, D., Minderhoud, P., and Schudel, W. (2016a). Pension funds' herding. De Nederlandsche Bank (DNB) working paper Nr., (503).

Broeders, D. and De Haan, L. (2020). Benchmark selection and performance. Journal of Pension Economics \&s Finance, 19(4):511-531.

Broeders, D. W. and Jansen, K. A. (2020). Liability-driven investors. Available at https://ssrn. com/abstract=3446239.

Broeders, D. W., Jansen, K. A., and Werker, B. J. (2020). Pension fund's illiquid assets allocation under liquidity and capital requirements. Journal of Pension Economics \& Finance, pages 1-23.

Broeders, D. W., van Oord, A., and Rijsbergen, D. R. (2016b). Scale economies in pension fund investments: A dissection of investment costs across asset classes. Journal of International Money and Finance, 67:147-171.

Brown, J. R. (2008). Guaranteed trouble: The economic effects of the pension benefit guaranty corporation. Journal of Economic Perspectives, 22(1):177-198.

Brown, J. R. and Wilcox, D. W. (2009). Discounting state and local pension liabilities. American Economic Review, 99(2):538-42.

Bruce, A. C. and Johnson, J. E. (1994). Male and female betting behaviour: New perspectives. Journal of Gambling studies, 10(2):183-198. 
Busse, J. A., Goyal, A., and Wahal, S. (2010). Performance and persistence in institutional investment management. Journal of Finance, 65(2):765-790.

Calvet, L. E., Campbell, J. Y., and Sodini, P. (2007). Down or out: Assessing the welfare costs of household investment mistakes. Journal of Political Economy, 115(5):707-747.

Campbell, J. Y. and Viceira, L. M. (2002). Strategic asset allocation: portfolio choice for long-term investors. Clarendon Lectures in Economic.

Carhart, M. M. (1997). On persistence in mutual fund performance. Journal of Finance, 52(1):57-82.

Clark, G. L. (2004). Pension fund governance: Expertise and organizational form. Journal of Pension Economics and Finance, 3(2).

Cocco, J. F., Gomes, F. J., and Maenhout, P. J. (2005). Consumption and portfolio choice over the life cycle. Review of Financial Studies, 18(2):491-533.

Cocco, J. F. and Volpin, P. F. (2007). Corporate Governance of Pension Plans: The U.K. Evidence. Financial Analyst Journal, 63(1):15.

Coggin, T. D., Fabozzi, F. J., and Rahman, S. (1993). The investment performance of us equity pension fund managers: An empirical investigation. Journal of Finance, 48(3):1039-1055.

Cohen, L., Frazzini, A., and Malloy, C. (2008). The small world of investing: Board connections and mutual fund returns. Journal of Political Economy, 116(5):951979 .

Congleton, R. D. (2004). The median voter model. In The encyclopedia of public choice, pages 707-712. Springer.

Coval, J. and Stafford, E. (2007). Asset fire sales (and purchases) in equity markets. Journal of Financial Economics, 86(2):479-512.

Cui, J., De Jong, F., and Ponds, E. (2011). Intergenerational risk sharing within funded pension schemes. Journal of Pension Economics $\&$ Finance, 10(1):1-29.

Dasgupta, A., Prat, A., and Verardo, M. (2011a). Institutional trade persistence and long-term equity returns. Journal of Finance, 66(2):635-653.

Dasgupta, A., Prat, A., and Verardo, M. (2011b). The price impact of institutional herding. Review of Financial Studies, 24(3):892-925.

Dietz, P. O. (1966). Pension funds: measuring investment performance. Free Press.

Dohmen, T., Falk, A., Golsteyn, B. H. H., Huffman, D., and Sunde, U. (2017). Risk Attitudes across the Life Course. Economic Journal, 127(605):F95-F116. 
Domanski, D., Shin, H. S., and Sushko, V. (2017). The hunt for duration: Not waving but drowning? IMF Economic Review, 65(1):113-153.

Dow, M. M., Burton, M. L., White, D. R., and Reitz, K. P. (1984). Galton's problem as network autocorrelation. American Ethnologist, 11(4):754-770.

Downs, A. (1957). An economic theory of political action in a democracy. Journal of Political Economy, 65(2):135-150.

Dutta, P. K. and Madhavan, A. (1997). Competition and collusion in dealer markets. Journal of Finance, 52(1):245-276.

Dyck, A. and Pomorski, L. (2011). Is bigger better? Size and performance in pension plan management. Size and Performance in Pension Plan Management (June 1, 2011). Rotman School of Management Working Paper, (1690724).

Elhorst, J. (2013). Spatial Econometrics: From Cross-Sectional Data to Spatial Panels. SpringerBriefs in Regional Science. Springer Berlin Heidelberg.

Faccio, M., Marchica, M.-T., and Mura, R. (2016). Ceo gender, corporate risk-taking, and the efficiency of capital allocation. Journal of Corporate Finance, 39:193-209.

Falk, A., Becker, A., Dohmen, T., Enke, B., Huffman, D., and Sunde, U. (2018). Global evidence on economic preferences. Quarterly Journal of Economics, 133(4):1645-1692.

Falkenstein, E. G. (1996). Preferences for stock characteristics as revealed by mutual fund portfolio holdings. Journal of Finance, 51(1):111-135.

Fama, E. F. and French, K. R. (2012). Size, value, and momentum in international stock returns. Journal of Financial Economics, 105(3):457-472.

Ferson, W. and Khang, K. (2002). Conditional performance measurement using portfolio weights: Evidence for pension funds. Journal of Financial Economics, $65(2): 249-282$.

Frederick, S., Loewenstein, G., and O'donoghue, T. (2002). Time discounting and time preference: A critical review. Journal of economic literature, 40(2):351-401.

Froot, K. A., Scharfstein, D. S., and Stein, J. C. (1992). Herd on the street: Informational inefficiencies in a market with short-term speculation. Journal of Finance, 47(4):1461-1484.

Gennaioli, N., Shleifer, A., and Vishny, R. (2015). Money doctors. Journal of Finance, 70(1):91-114.

Goyal, A. and Wahal, S. (2008). The selection and termination of investment management firms by plan sponsors. Journal of Finance, 63(4):1805-1847. 
Graham, J. R. (1999). Herding among investment newsletters: Theory and evidence. Journal of Finance, 54(1):237-268.

Greenwood, R., Vissing-Jorgensen, A., et al. (2018). The impact of pensions and insurance on global yield curves. Technical report, Harvard Business School.

Grinblatt, M., Titman, S., and Wermers, R. (1995). Momentum investment strategies, portfolio performance, and herding: A study of mutual fund behavior. American Economic Review, pages 1088-1105.

Hirschman, A. O. (1970). Exit, voice, and loyalty: Responses to decline in firms, organizations, and states, volume 25 . Harvard university press.

Hirshleifer, D., Subrahmanyam, A., and Titman, S. (1994). Security analysis and trading patterns when some investors receive information before others. Journal of Finance, 49(5):1665-1698.

Hotelling, H. (1929). Stability in competition. Economic Journal, 39(153):41-57.

Ibbotson, R. G. and Kaplan, P. D. (2000). Does asset allocation policy explain 40, 90, or 100 percent of performance? Financial Analysts Journal, 56(1):26-33.

Ibragimov, R., Jaffee, D., and Walden, J. (2011). Diversification disasters. Journal of Financial Economics, 99(2):333-348.

Jaiswal, S. (2017). Connections and conflicts of interest: Investment consultants' recommendations. Working Paper, Available at https://papers.ssrn.com/sol3 /papers. cfm?abstract_id=3221690.

Jenkinson, T., Jones, H., and Martinez, J. V. (2016). Picking winners? Investment consultants' recommendations of fund managers. Journal of Finance, 71(5):23332370 .

Jensen, M. and Meckling, W. (1976). Theory of the firm: Management behavior, agency costs and capital structure. Journal of Financial Economics, 3(4):305-60.

Jiang, H. and Verardo, M. (2018). Does herding behavior reveal skill? An analysis of mutual fund performance. Journal of Finance, 73(5):2229-2269.

Jones, H. and Martinez, J. V. (2017). Institutional investor expectations, manager performance, and fund flows. Journal of Financial and Quantitative Analysis, $52(6): 2755-2777$.

Keynes, J. M. (1936). The general theory of employment, interest and money. Macmillan.

Kowalewski, O. (2012). Corporate governance and pension fund performance. Contemporary Economics, 6(1):14-44. 
Lakonishok, J., Shleifer, A., and Vishny (1992a). The structure and performance of the money management industry. Brookings Papers on Economic Activity. Microeconomics, 1992:339-391.

Lakonishok, J., Shleifer, A., and Vishny, R. W. (1992b). The impact of institutional trading on stock prices. Journal of Financial Economics, 32(1):23-43.

LeSage, J. and Pace, R. K. (2009). Introduction to spatial econometrics. Chapman and Hall/CRC.

LeSage, J. P., Pace, R. K., Lam, N., Campanella, R., and Liu, X. (2011). New orleans business recovery in the aftermath of hurricane katrina. Journal of the Royal Statistical Society: Series A (Statistics in Society), 174(4):1007-1027.

Loewenstein, G. (2005). Hot-cold empathy gaps and medical decision making. Health psychology, 24(4S):S49.

Madrian, B. C. and Shea, D. F. (2001). The power of suggestion: Inertia in $401(\mathrm{k})$ participation and savings behavior. Quarterly journal of economics, 116(4):11491187.

Malmendier, U. and Nagel, S. (2011). Depression babies: Do macroeconomic experiences affect risk taking? Quarterly Journal of Economics, 126(1):373-416.

Matsa, D. A. and Miller, A. R. (2013). A female style in corporate leadership? Evidence from quotas. American Economic Journal: Applied Economics, 5(3):136169.

Merton, R. C. (1983). On consumption indexed public pension plans. In Financial aspects of the United States pension system, pages 259-290. University of Chicago Press.

Morin, R.-A. and Suarez, A. F. (1983). Risk aversion revisited. Journal of Finance, 38(4):1201-1216.

Mukherjee, B. and Singer, D. A. (2008). Monetary institutions, partisanship, and inflation targeting. International Organization, 62(2):323-358.

Myers, S. C. (1977). Determinants of corporate borrowing. Journal of Financial Economics, 5(2):147-175.

Nofsinger, J. R. and Sias, R. W. (1999). Herding and feedback trading by institutional and individual investors. Journal of Finance, 54(6):2263-2295.

OECD (2017). Pensions at a Glance $201 \%$.

OECD (2019). Pension markets in focus. Available at http://www .oecd.org/daf/f in/private-pensions/pensionmarketsinfocus.htm. 
OECD (2020). Pension markets in focus. Available at http://www oecd.org/finan $\mathrm{ce} /$ pensionmarketsinfocus .htm.

Pennacchi, G. and Rastad, M. (2011). Portfolio allocation for public pension funds. Journal of Pension Economics and Finance, 10(02):221-245.

Phan, H. V. and Hegde, S. P. (2013). Corporate governance and risk taking in pension plans: Evidence from defined benefit asset allocations. Journal of Financial and Quantitative Analysis, 48(3):919-946.

Poitevin, M. (1989). Collusion and the banking structure of a duopoly. Canadian journal of economics, pages 263-277.

Ponds, E. H. and Van Riel, B. (2009). Sharing risk: The netherlands' new approach to pensions. Journal of Pension Economics \& Finance, 8(1):91-105.

Rauh, J. D. (2009). Risk shifting versus risk management: Investment policy in corporate pension plans. Review of Financial Studies, 22(7):2687-2733.

Rossi, A. G., Blake, D., Timmermann, A., Tonks, I., and Wermers, R. (2018). Network centrality and delegated investment performance. Journal of Financial Economics, 128(1):183-206.

Scharfstein, D. S. and Stein, J. C. (1990). Herd behavior and investment. American Economic Review, pages 465-479.

Sharpe, W. F. and Tint, L. G. (1990). Liabilities-a new approach. Journal of Portfolio Management, 16(2):5-10.

Shi, L., Swinkels, L., and Van der Lecq, F. (2017). Board diversity and self-regulation in dutch pension funds. Equality, Diversity and Inclusion: An International Journal, 28(5):939-963.

Shleifer, A. and Vishny, R. W. (1997). A survey of corporate governance. Journal of Finance, 52(2):737-783.

Sialm, C., Starks, L. T., and Zhang, H. (2015). Defined contribution pension plans: Sticky or discerning money? Journal of Finance, 70(2):805-838.

Sias, R., Turtle, H. J., and Zykaj, B. (2015). Hedge fund crowds and mispricing. Management Science, 62(3):764-784.

Sias, R. W. (2004). Institutional herding. Review of Financial Studies, 17(1):165-206.

Sias, R. W., Starks, L. T., and Titman, S. (2006). Changes in institutional ownership and stock returns: Assessment and methodology. Journal of Business, 79(6):28692910 . 
Simmons, B. A. and Elkins, Z. (2004). The globalization of liberalization: Policy diffusion in the international political economy. American Political Science Review, 98(1):171-189.

Social-Investment-Forum (2018). Global sustainable investment review. Available at https://ww. ussif .org/index.asp.

Sunden, A. E. and Surette, B. J. (1998). Gender differences in the allocation of assets in retirement savings plans. American Economic Review, 88(2):207-211.

Swinkels, L. and Ziesemer, V. (2012). Diversity of dutch pension fund boards. Pensions: An International Journal, 17(3):137-143.

Treynor, J. L. (1977). The principles of corporate pension finance. Journal of Finance, $32(2): 627-638$.

van Binsbergen, J. H., Brandt, M. W., and Koijen, R. S. (2008). Optimal decentralized investment management. Journal of Finance, 63(4):1849-1895.

van Nunen, A. (2011). Fiduciary management: Blueprint for pension fund excellence, volume 415. John Wiley \& Sons.

Verma, A. and Weststar, J. (2011). Token presence or substantive participation? A study of labor trustees on pension boards. Journal of Labor Research, 32(1):39-60.

Vieider, F. M., Lefebvre, M., Bouchouicha, R., Chmura, T., Hakimov, R., Krawczyk, M., and Martinsson, P. (2015). Common components of risk and uncertainty attitudes across contexts and domains: Evidence from 30 countries. Journal of the European Economic Association, 13(3):421-452.

Wei, K. D., Wermers, R., and Yao, T. (2015). Uncommon value: The characteristics and investment performance of contrarian funds. Management Science, 61(10):2394-2414.

Wermers, R. (1999). Mutual fund herding and the impact on stock prices. Journal of Finance, 54(2):581-622.

Wijnbergen, S. v. (1992). Intertemporal speculation, shortages and the political economy of price reform. Economic Journal, 102(415):1395-1406.

World Bank (1994). Averting the old age crisis: Policies to protect the old and promote growth. A World Bank Policy Research Report.

Zingales, L. (2000). In search of new foundations. Journal of Finance, 55(4):16231653. 


\section{About the author}

Matteo Bonetti was born on August 2, 1991, in Savigliano, Italy. He received his Bachelor's degree in Economics and Finance (2013) and Master's degree in Quantitative Finance and Insurance (2016) from the University of Turin.

In 2016, he joined the Finance Department at Maastricht University as a Ph.D. candidate under the supervision of Rob Bauer and Dirk Broeders. Matteo's fields of research are asset management, institutional investors, financial networks, empirical asset pricing, and pension finance. He presented his research at international conferences and seminars at the University of Amsterdam, De Nederlandsche Bank, Rotman School of Management, Global Risk Institute, and Schulich School of Business. Matteo has taught graduate and undergraduate finance and financial economics courses.

During his Ph.D Matteo was affiliated to De Nederlandsche Bank, as an external researcher. In 2019 he was visiting scholar at Rotman School of Management at the University of Toronto hosted by Mike Simutin.

In September 2020, Matteo joined the financial markets division of De Nederlandsche Bank, as financial risk manager and researcher. 


